UNIVERSIDADE DE SÃO PAULO

FACULDADE DE SAÚDE PÚBLICA

ELTON TONY SOUZA PONDÉ COELHO

O perfil sanitarista do Parlamento brasileiro:

caminhos, interesses e conquistas da saúde nas Assembleias Nacionais

Constituintes de 1946 e 1987-88.

São Paulo

2019 
O perfil sanitarista do Parlamento brasileiro:

caminhos, interesses e conquistas da saúde nas Assembleias Nacionais Constituintes de 1946 e 1987-88.

Dissertação de Mestrado - v. único

Dissertação de mestrado apresentada à Banca Examinadora da Faculdade de Saúde Pública da Universidade de São Paulo - USP, como requisito parcial para a obtenção do título de Mestre em Ciências.

Área de Concentração: Programa Saúde Pública.

Orientadora: Prof $\stackrel{a}{\text { a }}$ Drª . Sueli Gandolfi Dallari. 
Autorizo a reprodução e divulgação total ou parcial deste trabalho, por qualquer meio convencional ou eletrônico, para fins de estudo e pesquisa, desde que citada a fonte.

Catalogação na publicação

Ficha elaborada pelo Serviço de Biblioteca e Documentação a partir dos dados fornecidos pelo(a) autor(a).

Bibliotecária da FSP/USP: Maria do Carmo Alvarez - CRB-8/4359

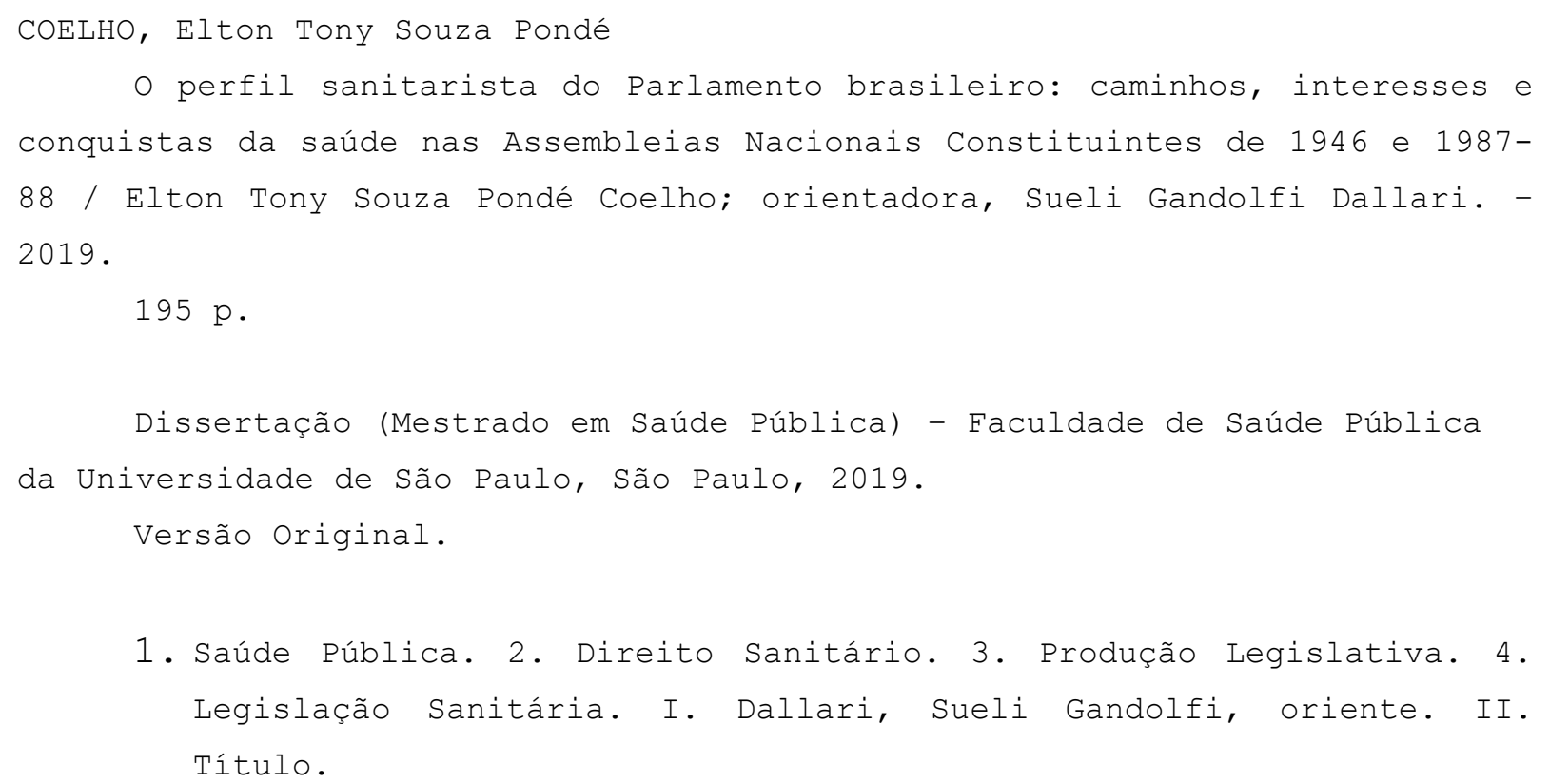


Título: O perfil sanitarista do Parlamento brasileiro: caminhos, interesses e conquistas da saúde nas Assembleias Nacionais Constituintes de 1946 e 1987-88.

Dissertação de mestrado apresentada à Banca Examinadora da Faculdade de Saúde Pública da Universidade de São Paulo - USP, como requisito parcial para a obtenção do título de Mestre em Ciências.

Aprovado em:

Banca Examinadora

Presidente: Prof ${ }^{a}$. Dr . Sueli Gandolfi Dallari Assinatura:

Prof ${ }^{\mathrm{a}}$. $\mathrm{Dr}^{\mathrm{a}}$. Instituição: Julgamento:

Prof ${ }^{\mathrm{a}}$. Dr ${ }^{\mathrm{a}}$.

Instituição:

Julgamento:

Prof ${ }^{a}$. Dra ${ }^{\mathrm{a}}$.

Instituição:

Julgamento: 


\section{AGRADECIMENTOS}

A Deus, o artífice de tudo.

Às minhas filhas Clara e Lis, que floresceram no decorrer desta pesquisa.

À minha esposa, Priscilla, a maior incentivadora.

Aos meus pais, irmãos e sobrinhos, cujo amor me inspirou.

Às minhas tias, cujo suporte sempre me permitiu seguir adiante.

Ao meu avô, a quem agradeço e, também, dedico.

À minha orientadora, professora Sueli, meu exemplo acadêmico.

À professora Iraíma, partícipe de minhas conquistas.

À USP e à FSP, aos docentes e funcionários, pela vivência acadêmica.

Ao CEPEDISA, pelas grandes oportunidades.

Ao CNPq, agência financiadora desta pesquisa.

À Câmara dos Deputados, em seu corpo técnico, pelo auxílio.

Aos que lutaram pela saúde pública brasileira, a quem tudo devemos. 
"Chegamos! Esperamos a Constituição como o vigia espera a aurora1".

(GUIMARÃES, 2008, p. 596).

${ }^{1}$ Discurso proferido pelo Presidente da ANC 1987-88, Ulysses Guimarães, na sessão de 05 de outubro de 1988. 


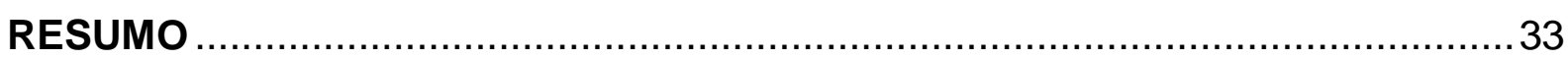

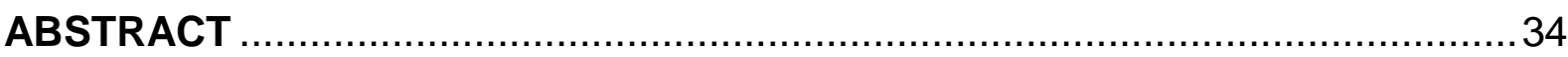

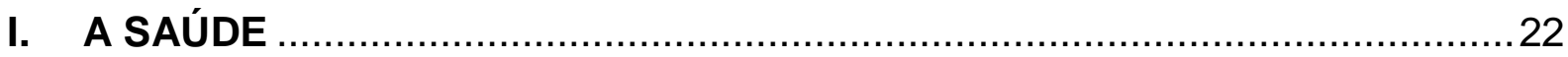

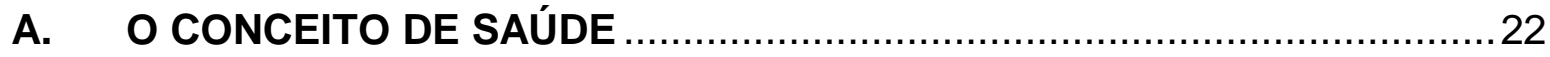

B. A SÁUDE NAS CONSTITUIÇÕES BRASILEIRAS …............................24

C. O DIREITO À SAÚDE E AS CONSTITUIÇÕES …................................ 33

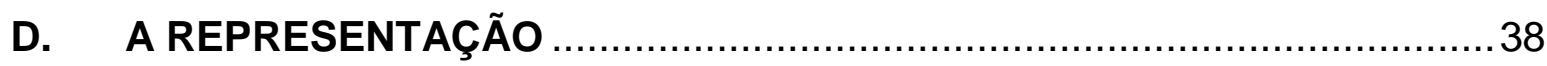

II. ASSEMBLEIAS NACIONAIS CONSTITUINTES 1946 E 1987-88 ...................44

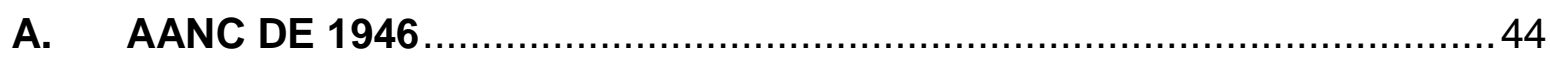

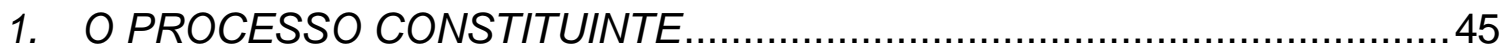

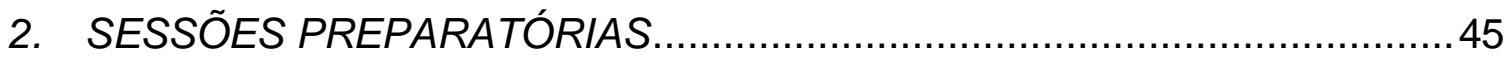

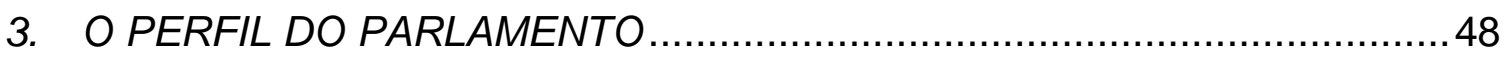

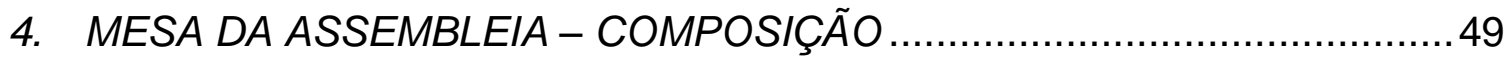

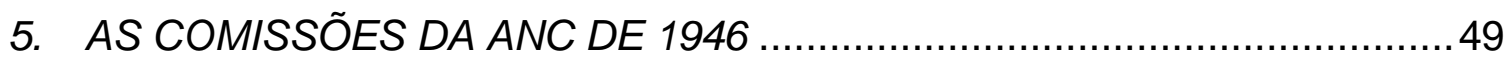

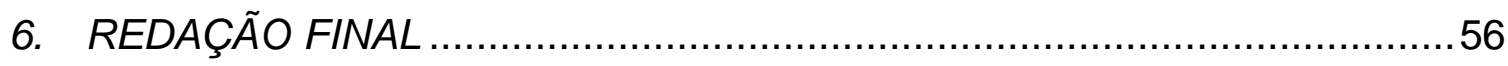

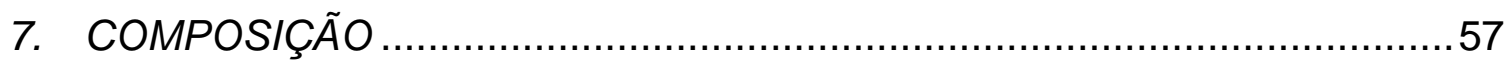

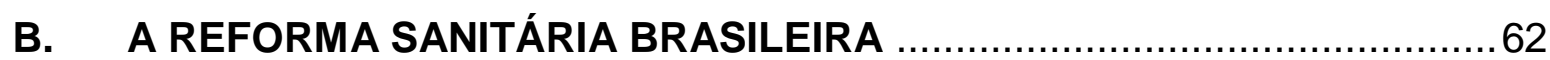

1. COMISSÃO NACIONAL DA REFORMA SANITÁRIA - CNRS ...................64

2. 8 CONFERÊNCIA NACIONAL DE SAÚDE - CNS ..................................64

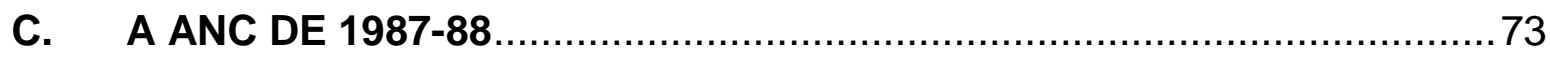

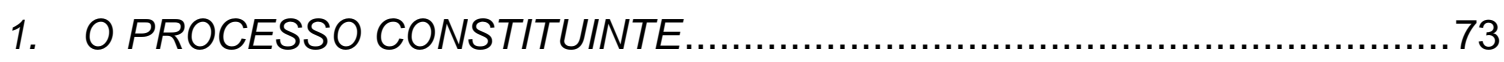

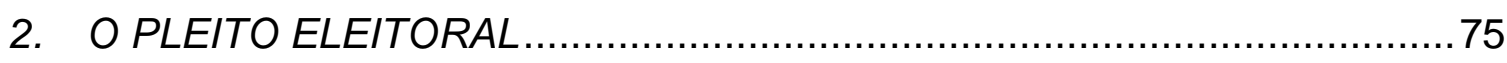

3. OS PARTIDOS POLÍTICOS NA ANC 1988............................................ 76

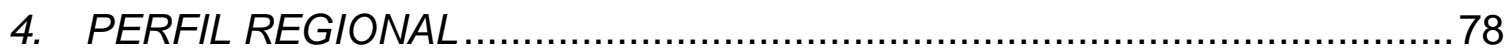

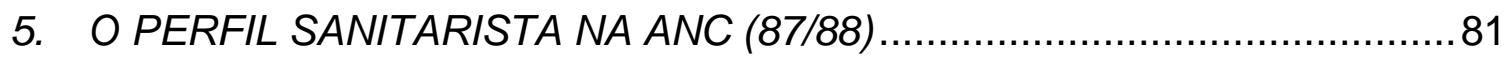

6. A PARTICIPAÇÃO DAS MULHERES NA ANC (87/88) ........................... 85

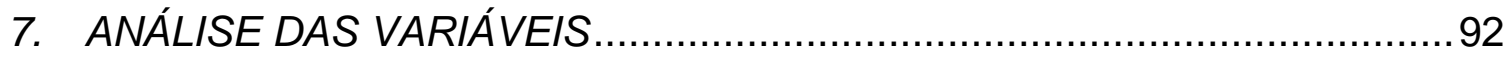

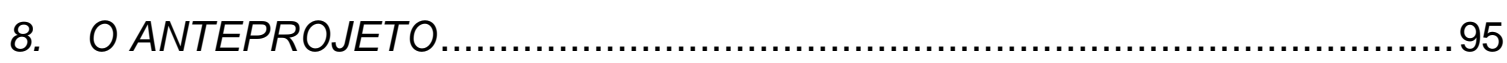

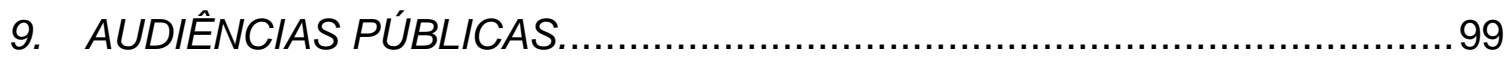

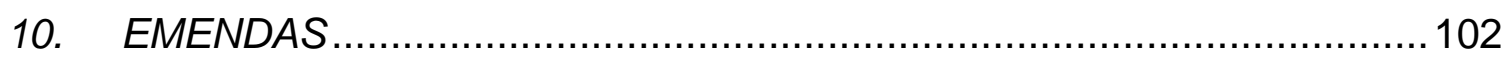

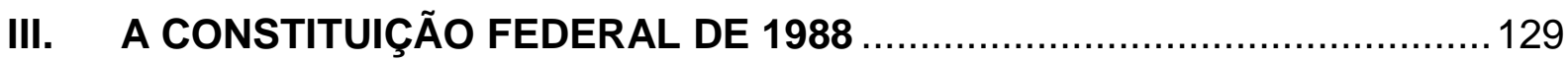

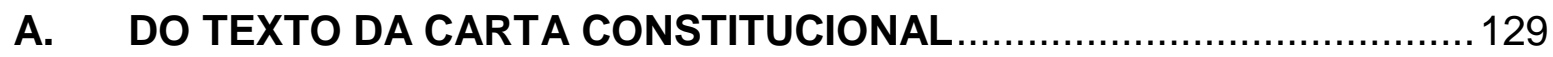


B. ANÁLISE DOS DISPOSITIVOS CONSTITUCIONAIS - SAÚDE ..............129

1. ART. $1^{\circ}-$ CIDADANIA E DIGNIDADE DA PESSOA HUMANA................129

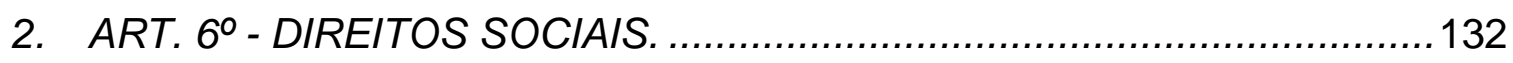

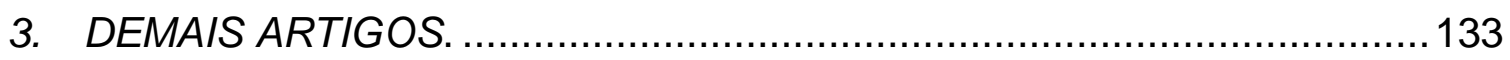

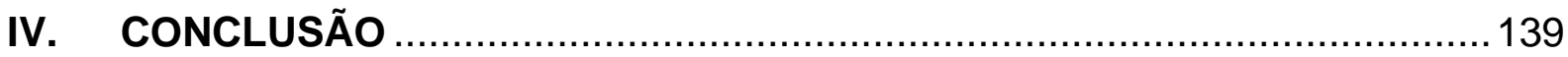

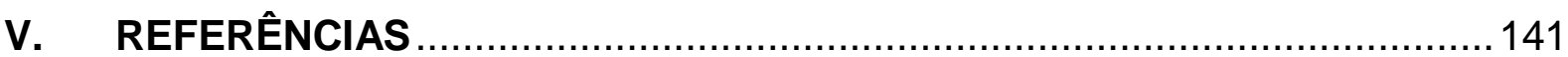




\section{ÍNDICE DE TABELAS}

Tabela 1: Quadro Comparativo: Constituições do Brasil Independente (1824 a 1988) .30

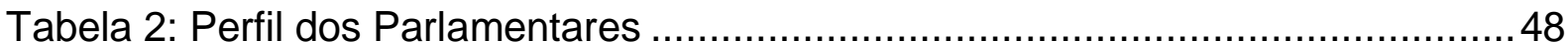

Tabela 3: Composição da Mesa da ANC de 1946 ................................................ 49

Tabela 4: Organização das Comissões e Subcomissões da ANC 46.......................49

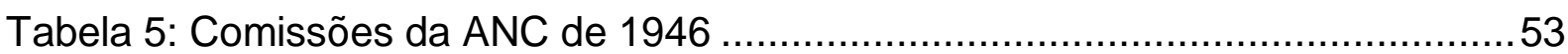

Tabela 6: Emendas ao Art. 5 da Constituição de 1946.............................................55

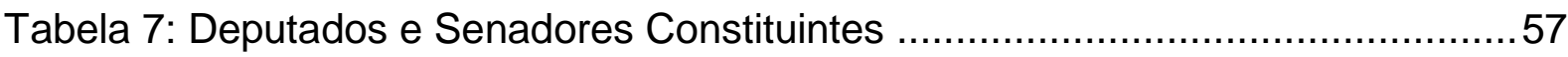

Tabela 8: Distribuição das profissões na área da saúde dos parlamentares que participaram da constituinte de 1946 - Deputados..............................................59

Tabela 9: Quadro: Organização dos Trabalhos da ANC 87/88 ...............................74

Tabela 10: Composição das Bancadas Partidárias na instalação da ANC de 1987-88

Tabela 11: Quadro: Perfil regional dos(as) deputados(as) constituintes - CF 87/88 79 Tabela 12: Percentual de Constituintes Sanitaristas x Região ............................... 80

Tabela 13: Distribuição das profissões na área da saúde dos parlamentares que

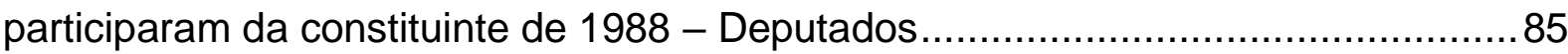

Tabela 14: Composição Geral da ANC de 87/88, segundo gênero ........................... 86

Tabela 15: Frequência de gênero na ANC x profissões sanitaristas .......................8 87

Tabela 16: Composição da Bancada Feminina (nome, partido, estado e profissão) 88 Tabela 17: Distribuição das profissões na área da saúde dos parlamentares que participaram da constituinte de 1988 - bancada feminina ...................................... 89

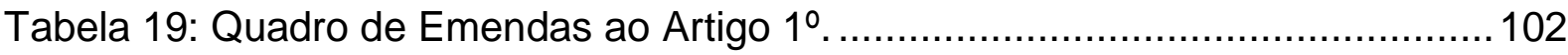

Tabela 20: Quadro de Temas das Emendas ao Anteprojeto na "FASE B" ............. 104

Tabela 21: Quadro de Emendas ao Anteprojeto - FASE B ................................ 106

Tabela 18: CF 88: Dos Princípios Fundamentais ................................................. 130

Tabela 22: CF 88: Dos Princípios Fundamentais ............................................... 133

Tabela 23: CF: Dos Direitos e das Garantias Fundamentais (Capítulo I) ............... 134

Tabela 24: CF 88: Dos Direitos e das Garantias Fundamentais (Capítulo II) ......... 135

Tabela 25: CF 88: Da Organização do Estado (Capítulo II) ...................................136

Tabela 26: CF 88: Da Organização do Estado (Capítulo III)....................................137

Tabela 27: CF 88: Da Organização do Estado (Capítulo IV) ..................................138 


\section{ÍNDICE DE FIGURAS}

Figura 1: Distribuição das profissões na área da saúde dos parlamentares que participaram da constituinte de 1946 - Deputados 59

Figura 2: Distribuição dos parlamentares por partido político. 60

Figura 3: Distribuição dos parlamentares por Estado 60

Figura 4: Dispersão dos parlamentares profissionais de saúde em relação ao partido político e ao estado - constituinte de 1946 - Deputados. 61

Figura 5: Gráfico: número de deputados(as) x partido ..............................................78

Figura 6: Frequência de Constituintes $x$ UF 80

Figura 7: Quadro Profissional dos Constituintes de $87 / 88$ em relação à área da saúde 83

Figura 8: Distribuição das profissões na área da saúde dos parlamentares que participaram da constituinte de 1988 - Deputados

Figura 9: Gráfico relação de gênero na composição da ANC 87/88 .86

Figura 10: Distribuição das profissões na área da saúde dos parlamentares que participaram da constituinte de 1988 - bancada feminina. .90

Figura 11: Gráfico com as profissões das parlamentares que participaram da constituinte de 1988 - bancada feminina 91

Figura 12: Dispersão dos parlamentares profissionais de saúde em relação ao gênero - constituinte de 1988 - Deputados. .93

Figura 13: Dispersão dos parlamentares profissionais de saúde em relação ao partido político e ao estado - constituinte de 1988 - Deputados .94 


\section{SIGLÁRIO}

ABEN Associação Brasileira de Enfermagem

ABRASCO Associação Brasileira de Pós-Graduação em Saúde Coletiva

ANC Assembleia Nacional Constituinte

ANM Associação Nacional de Medicina

CD Câmara dos Deputados

CEBES Centro Brasileiro de Estudos de Saúde

CF Constituição Federal

CNRS Comissão Nacional da Reforma Sanitária

CNS Conferência Nacional de Saúde

CONAM Confederação Nacional de Associação de Moradores

CONASS Conselho Nacional de Secretários de Saúde

CONESPSE Coord. Nac. de Entidades Sindicais e Pré-sindicais de Enfermagem

CGT Confederação Geral dos Trabalhadores

CS Comissão de Sistematização

CUT Central Única dos Trabalhadores

DANC Diário da Assembleia Nacional Constituinte

DETRAN Departamento Estadual de Trânsito

DNER Departamento Nacional de Estradas de Rodagem

EC Emenda Constitucional

EMATER Empresa de Ass. Téc. e Extensão Rural do Estado de MG

ES Emenda ao Substitutivo

FEDF Faculdade de Educação Física e Dança da Univ. Federal de MG

FIOCRUZ Fundação Oswaldo Cruz

HRAS Hospital Regional da Asa Sul - Brasília

IML Instituto Médico Legal

INDA Instituto Nacional de Desenvolvimento Agrário

INAMPS Instituto Nacional de Assistência Médica da Previdência Social

INAPETEC Instituto de Apos. e Pensões dos Estivadores do Tranp. de Cargas

INPS Instituto Nacional de Previdência Social

MEC Ministério da Educação

MPAS Ministério da Previdência e Assistência Social

MUP Movimento de Unidade Popular 
MS Ministério da Saúde

OMS Organização Mundial de Saúde

PL Projeto de Lei

PCB Partido Comunista Brasileiro

PC do B Partido Comunista do Brasil

PDT Partido Democrático Trabalhista

PDS Partido Democrático Social

PFL Partido da Frente Liberal

PL Partido Libertador ${ }^{2}$

PMDB Partido do Movimento Democrático Brasileiro

PR Partido Republicano

PSB Partido Socialista Brasileiro

PSC Partido Social Cristão

PSD Partido Social Democrático

PSDB Partido da Social Democracia Brasileira

PSP Partido Social Progressista

PT Partido dos Trabalhadores

PTB Partido Trabalhista Brasileiro

RSB Reforma Sanitária Brasileira

SBPC Sociedade Brasileira para o Progresso da Ciência

SF $\quad$ Senado Federal

SILOS Sistemas Locais de Saúde

STF Supremo Tribunal Federal

SUDS Sistema Único Descentralizado de Saúde

SUPRA Superintendência da Política Agrária

SUS S Sistema Único de Saúde

TSE Tribunal Superior Eleitoral

UDN União Democrática Nacional

UFMT Universidade Federal de Mato Grosso

\footnotetext{
${ }^{2}$ Embora utilizem a mesma sigla, trata-se do Partido Libertador (PL) fundado em 1945 e extinto em 1965 e não do Partido Liberal (fundado na década de 80). Antes disso, o existiu o Partido Libertador gaúcho (1928-1937), também PL.
} 


\section{GLOSSÁRIO DE TERMOS CONSTITUINTES}

Anais da ANC - Os anais da ANC integram importante patrimônio da história legislativa do país, através do Arquivo da Câmara dos Deputados. São livros que compõe os registros das sessões, audiências públicas e deliberações das ANCs do país. O material é disponibilizado fisicamente na Biblioteca da CD e virtualmente.

Anteprojeto - Trata-se do primeiro trabalho consolidado dos constituintes apresentado à Comissão de Sistematização.

Assembleia Nacional Constituinte (ANC) - Na definição de Norberto Bobbio, tratase de "um órgão colegial, representativo, extraordinário e temporário, que é investido da função de elaborar a Constituição do Estado, de pôr - em outros termos - as regras fundamentais ordenamento jurídico estatais" (BOBBIO, N. 1992).

Autor - Indivíduo responsável por criar ou propor uma lei, emenda etc.

Base APEM - Base de Dados criada pelo Senado Federal com informações concernentes à ANC de 1987-88.

Comissão Temática - É o órgão parlamentar responsável pelo trabalho específico em determinada área, podendo ser permanente ou temporária.

Congresso Nacional - Representa o Poder Legislativo, sendo composto pela Câmara dos Deputados e pelo Senado Federal.

Deputado Constituinte - É o parlamentar da Câmara dos Deputados que integra a elaboração da Constituição Federal, através da ANC.

Diários da ANC - É o registro oficial das sessões da ANC, disponível fisicamente e por meio eletrônico pela Biblioteca da Câmara dos Deputados.

Emenda - Trata-se de uma proposição para adição, substituição, supressão ou modificação de uma legislação.

Emenda Substitutiva - Trata-se de uma emenda que requer a alteração substancial do texto de uma proposição anterior.

Emenda Aditiva - É a emenda que propõe a adição de novo conteúdo ao texto inicial.

Emenda Supressiva - Visa a retirada de parte do texto inicial.

Emenda Modificativa - São as que propõem mudanças pontuais no texto inicial, mantendo-se, contudo, seus objetivos principais.

Fases - Constituem, nas ANCs, as etapas de elaboração do texto constitucional e sua passagem pelas comissões temáticas. 
Justificativa - Trata-se da argumentação elaborada pelo legislador a fim de fundamentar sua proposição.

Legislação Ordinária - São as leis mais gerais e abstratas, estando presentes na Constituição Federal.

Parecer - É a opinião elaborada sobre um assunto, baseada em uma fundamentação.

Plenário - Trata-se do local onde ocorrem as sessões legislativas.

Promulgada - Trata-se da aprovação da Constituição pelos representantes do povo.

Outorgada - Trata-se da imposição de um texto constitucional ao povo pelo seu governante. 


\section{RESUMO}

COELHO, Elton Tony Souza Pondé. O perfil sanitarista do Parlamento brasileiro: caminho, interesses e conquistas da saúde nas Assembleias Nacionais Constituintes de 1946 e 1987-88. 2019. 195 f. Dissertação (Mestrado em Saúde Pública) - Faculdade de Saúde Pública, Universidade de São Paulo, 2019.

As conquistas dos direitos sociais brasileiros, especialmente à saúde, atrelam-se à dinâmica da 'representação democrática' no país. A lógica de composição do Congresso Nacional e, particularmente, das Assembleias Nacionais Constituintes importantes esferas de participação - representam avanços e retrocessos na pauta sanitária. Analisamos, nesta pesquisa, o 'perfil sanitário' do Parlamento brasileiro, a partir da formação escolar, filiação partidária e região geográfica dos constituintes nas ANCs de 1946 e 1987-88, que exprimiram a primeira incidência da pauta sanitária em um texto constitucional e a consolidação de luta da $8^{\text {a }}$ Conferência Nacional de Saúde, respectivamente. Ao contrário do que possa parecer, 'mais parlamentares da saúde' não representaram 'mais leis sanitárias'. O estudo demonstrou que o recrutamento político das profissões da saúde não logrou êxito determinante no avanço sanitário. As conquistas da ANC de 1987-88 foram alcançadas pelos movimentos sociais e pela própria consolidação do 'conceito de saúde', capitaneada por parlamentares solitários, frente ao corporativismo de outros seguimentos.

Descritores: Saúde Pública; Direito Sanitário; Parlamento; Legislação Sanitária. 


\begin{abstract}
COELHO, Elton Tony Souza Pondé. The sanitary profile of the Brazilian Parliament: path, interests and achievements of health in the National Constituent Assemblies of 1946 and 1987-88. 2019. 195 f. Dissertation (Master in Public Health) - Faculty of Public Health, University of São Paulo, 2019.

The achievements of Brazilian social rights, especially health, are tied to the dynamics of 'democratic representation' in the country. The logic of composition of the National Congress, and particularly of the National Constituent Assemblies important spheres of participation - represent advances and setbacks in the health agenda. In this research, we analyzed the Brazilian health profile of the Brazilian Parliament, based on school education, party affiliation and geographical region of the constituents in the 1946 and 1987-88 ANCs, who expressed the first incidence of the health agenda in a constitutional text and the consolidation of the 8th National Health Conference, respectively. Contrary to what might seem, 'more health parliamentarians' did not represent 'more sanitary laws'. The study showed that the political recruitment of the health professions did not make a decisive success in advancing health. The achievements of the ANC of 1987-88 were achieved by social movements and by the consolidation of the 'health concept', led by solitary parliamentarians, as opposed to the corporatism of other segments.
\end{abstract}

Keywords: Public Health; Health Law; Parliament; Health Legislation. 


\section{INTRODUÇÃO}

As conquistas dos direitos sociais brasileiros, especialmente à saúde, atrelam-se à dinâmica da 'representação democrática' no país. A princípio, roga-se ao recrutamento político dos 'sanitaristas' enquanto suficientes à pauta da saúde pública, 'mais parlamentares da área da saúde, mais leis sanitárias'. Há, contudo, outros fatores indissociáveis à questão: a permeabilidade das pautas sociais no Congresso Nacional - capitaneada pela pressão dos movimentos populares e por expoentes dessas causas eleitos - a ampliação dos próprios sentidos de 'saúde' e, por fim, a tradução disto na lei, ou seja, nas Constituições brasileiras, a que nos atemos aqui.

Ao longo da história do Brasil independente foram elaboradas, sendo promulgadas ou outorgadas, sete Constituições: iniciando-se em 1824, ainda no período imperial, já na história republicana as Constituições de 1891, 1934, 1937, 1946, 1967 e, em vigor hoje, a Constituição Federal de 1988. Houve, ainda, a Emenda Constitucional №. 1 de 30 de novembro de 1969, decretada pela Junta Militar, em razão do golpe de 1964. A saúde, enquanto garantia constitucional, contudo, surge no país, efetivamente, apenas com a Constituição de 1988, fruto de amplo debate na $8^{a}$ Conferência Nacional de Saúde e da mobilização de vários seguimentos da sociedade civil. Antes, de maneira incipiente, apenas a Constituição de 1946, que imputou à União a responsabilidade de legislar sobre 'normas gerais de defesa e proteção da saúde', tratou do tema.

As Constituições, enquanto normas superiores, remetendo-nos a Kelsen (1997), estabelecem os limites do poder legiferante das 'normas inferiores' e às quais, em certa medida, determinam-Ihe o conteúdo, servindo-as como 'fundamento imediato de validade', ou seja, a presença da 'saúde' nas Constituições brasileiras representou a efetivação deste direito e a sua asseguridade nas legislações delas decorrentes, donde sua importância na efetivação do direito à saúde no Brasil e a razão deste estudo. Vendo-se a lei 8.080 de 19 de setembro de 1990, que criou o Sistema Único de Saúde, marco sanitário no país, somente foi possível em razão das garantias constitucionais preconizadas na Constituição de 1988, promulgada a partir da Assembleia Nacional Constituinte de 1987-88, já no período democrático.

À dinâmica da 'representação democrática' nas ANCs, impõem-se os mecanismos de participação e recrutamento político das casas legislativas. Alguns 
trabalhos acadêmicos debruçaram-se sobre o 'recrutamento das profissões na política'. Sérgio Soares Braga (1998) aprofundou-se em 'quem foi quem' na elaboração da Constituição de 1946. Leôncio Martins Rodrigues (2009) evidenciou uma 'profissionalização da atividade de representação política'. Ambos identificaram a preponderância de determinadas áreas profissionais, recrutadas pelo sistema político. Rodrigues (2009) sinalizou para uma mudança, com a ascensão das classes populares e trabalhadoras aos espaços de poder, fruto de maior mobilização social.

Braga (1998) traçou o perfil da ANC de 1946, 'quem foi quem na Constituição de 46', sob aspectos sociais, políticos, partidários, regionais e profissionais. Evidenciou que dos 338 constituintes (297 deputados e 41 senadores), 56\% eram provenientes das carreiras jurídicas. $O$ recrutamento de advogados na política era seguido dos profissionais da saúde, que representaram 16\% (bem inferior à liderança), sendo a segunda área mais bem representada. Ainda que as eleições de 1945 tenham ampliado a representação partidária na ANC do ano seguinte, somente pequena parcela da população compunha o eleitorado.

Já a ANC de 1987-88 foi elaborada em condições diversas das precedentes, contando com um amplo corpo eleitoral, que alçou ao Parlamento $559^{3}$ constituintes, sendo 487 deputados federais eleitos em 1986 e 72 senadores, destes 23 eleitos em 1982 e 49 nas eleições de 1986. A profissão com maior incidência dentre os constituintes, em 1987-88, foi a advocacia com $43 \%$ dos representantes. Os profissionais da saúde representaram $11,5 \%$ dentre os constituintes. Um dos estudos da professora Sueli Dallari (2009) retratou a ampla participação da sociedade civil organizada neste processo, o que para Aith (2006) significou algo até então não atingido pelo Direito Sanitário - ramo que estuda o direito à saúde - no Brasil.

Reconhecidamente, a CF 88 representou um avanço sem precedentes na evolução do direito à saúde no país, ainda que o número de representantes do seguimento na ANC não seja o mais expressivo. A ANC contou, contudo, com uma forte movimentação prévia, movida pela $8^{\circ} \mathrm{CNS}$, focalizando seus objetivos em deputados-chaves, que foram os 'expoentes da causa'.

\footnotetext{
${ }^{3}$ Contudo, consideramos neste estudo os 593 parlamentares que assumiram mandato na ANC de 1987-88 (512 deputados e 81 senadores).
} 
Essa dinâmica da 'representação' na teoria política foi estudada por diversos autores. Hanna Pitkin (1972) dedicou-se aos vários sentidos da representação, enquanto forma, símbolo e ação, como correspondência com o todo e a representação como ação em nome de outrem. Problematizou, ainda, "a impossibilidade lógica de que, na esfera de poder, haja, identidade de vontade entre representante e representado" (CORVAL, 2015).

John Stuart Mill (1981) possui uma obra clássica, frequentemente, requerida ao tratar de representação. "Considerações sobre o Governo Representativo" preocupou-se, não apenas com a estrutura dos governos representativos mas também com a democracia atenta à qualificação dos cidadãos, assegurando-lhe a participação na esfera pública.

A representação da saúde nas ANCs de 1946 e 87-88, traduzida nas Constituições de 46 e 88, revela o poder de 'representação' dos movimentos originários dessas pautas e da capacidade de recrutamento do sistema político, sensível ou não às causas sanitárias. Realizamos uma pesquisa com dados da composição das ANCs e de sua dinâmica de funcionamento, evidenciando que não apenas 'as profissões da profissão política' são determinantes, mas também dois fatores: a mobilização da sociedade civil organizada e a lógica de representação desses seguimentos no sistema político.

Imaginar-se-ia, inicialmente, estreita correlação da profissão sanitária com emendas aos projetos das Constituições de 1946 e 1988. Não apenas o 'sistema político' dispersou esses agentes, como o próprio tema da 'saúde' não recebeu destaque na organização dos trabalhos constituintes. Em 1946, não houve qualquer menção à saúde nas denominações das comissões e subcomissões, os temas foram englobados em comissões genéricas, donde é difícil até mesmo classificar a pauta da saúde. Nesse contexto, apenas $27 \%$ dos sanitaristas envolveram-se em alguma comissão. Em 1987-88, por sua vez, a subcomissão responsável foi bem definida, porém sem destaque e permeada por outras pautas: 'Comissão de Saúde, de Seguridade e do Meio Ambiente'.

Dentre as preposições, 'poucos falaram por muitos' na luta dos sanitaristas. Os anseios da sociedade civil organizada foram expressados por parlamentares isolados. A maioria ateve-se à defesa da saúde privada, desde 1946, ou em proposições especificas de causas variadas (como os pecuaristas) ou inexpressivas no cenário nacional (causas regionais). Eduardo Jorge, constituinte paulista, foi 
responsável pelo envio de 24,5\% das emendas ao Projeto da Constituição de 1988, na maioria solicitando a inclusão de temas caros a 8ª CNS, sobre a comercialização de órgãos, distribuição de medicamentos, saúde do trabalhador, segurança alimentar etc.

Isto posto, buscamos neste trabalho estudar as Assembleias Nacionais Constituintes de 1946 e 1987-88 - cujo importância à pauta sanitária já foi abordada inicialmente - mas sobre a perspectiva inaugurada por Sérgio Braga de 'quem foi quem' na construção da saúde enquanto garantia constitucional, para tanto é imprescindível entendermos o contexto de elaboração destas cartas, 'quem eram' e 'quantos eram' os parlamentares sanitaristas, se estes de fato atuaram na causa, bem como, quais as influências carregaram para o Parlamento. As pistas, na ANC de 1987-88, estão incontornavelmente na 8 CNS. 1946 é o recurso comparativo, a base para confrontar o que queremos demonstrar: a atuação da sociedade civil foi fundamental e a atuação isolada, porém robusta, de 'parlamentares-chaves' foi o caminho percorrido pela saúde brasileira para consolidar-se na Constituição Federal de 1988.

Os ensejos desta pesquisa aqui no final desta introdução relatados - porém não menos importantes - provém dos aprendizados no Centro de Estudos e Pesquisas em Direito Sanitário, o CEPEDISA, da USP. Cujo espírito investigativo no levou a perguntas fundamentais: o que move os parlamentares a atuarem na causa sanitária? Qual diferença é possível inferir na legislação em prol da saúde? Quem fez e faz a saúde brasileira? São algumas perguntas que humildemente apontaremos a seguir. 


\section{A SAÚDE}

\section{A. O CONCEITO DE SAÚDE}

Em diversos contextos sociais e nos variados recortes temporais, há diferentes maneiras de enxergar e denominar o que se entenda por 'saúde'. A literatura atribui, frequentemente, o conceito de saúde à ausência de doença. Tal concepção está associada, historicamente, às descobertas científicas dos agentes causadores de moléstias e seu, consequente, isolamento, bem como, à invenção de fármacos, que possibilitaram a cura de muitas enfermidades. Não estar doente, portanto, era sinônimo de possuir saúde (DALLARI, S. G.; NÚNES JÚNIOR, 2010).

O conceito de saúde perpassa, contudo, por um longo processo histórico, construído desde a antiguidade até os dias atuais, possuindo tanto um caráter histórico quanto simbólico para cada sociedade. Aos gregos, por exemplo, 'saúde' significava 'hygieia': "o estado daquele que está bem com a vida". Incorporado a uma gama de saberes da medicina e aos conceitos de dietética e ginástica ${ }^{4}$, consideravam a dimensão e importância da cura. Já Platão alargou esse sentido, agregando o valor da alma, destacando o necessário equilíbrio desta com o corpo. $\mathrm{Na}$ antiguidade, então, a concepção de saúde estava associada ao estado de equilíbrio interno do homem e deste com a organização social; e a natureza é considerada sinônimo de saúde (DALLARI, S. G., 2005, p. 10).

O início da concepção atual de saúde que temos hoje se dá no Renascimento, em consonância com o surgimento do Estado Moderno. À época, a assistência pública (aos desamparados) e a assistência médica dependiam da ação de 'solidariedade da vizinhança' nas comunidades locais. O Estado intervia apenas onde essa se apresentava insuficiente. A ação subsidiária do Estado foi um primeiro passo para a concepção do que se consolidou, posteriormente, como serviço público de saúde. Com o Estado Liberal, a 'saúde' adquiriu seu escopo legal, atrelada com a polícia administrativa e com a proteção da saúde. Predominavam as ações de vigilância sanitária, que "eram em tudo coincidentes com os interesses da burguesia vitoriosa: valorizando sobremaneira o individualismo dominante, limitá-lo apenas naquilo estritamente necessário à preservação da segurança individual" (DALLARI, S. G. 2005, p. 11).

\footnotetext{
${ }^{4}$ Dietética ou Ciências dos Regimes e Ginástica ou Ciência dos Exercícios.
} 
Somente depois, o discurso sanitarista ganhou na Europa força no contexto nuclear da medicina social, com origens na polícia médica da Alemanha, na medicina urbana da França e na medicina da força do trabalho da Inglaterra. Contudo, o caráter social da medicina e da doença viria a eclodir apenas na segunda metade do século XIX, com um movimento, que se estenderia por toda a Europa, reunindo médicos, filósofos e pensadores. Surgem, nesse período, grandes questionamentos sobre o fim da política da tradição, das monarquias, da sucessão nas dinastias, como o direito divino, em meio a inúmeros problemas relacionados às precárias condições de vida da classe operária (FINKELMAN, 2002).

Segundo Galvão (2012), o final do século XIX representou grandes mudanças na saúde pública, sobretudo, em relação ao conhecimento médico sanitarista, que incorporou saberes experimentais ${ }^{5}$. Nas décadas seguintes, já no século $X X$, no contexto mundial, a Constituição da Organização Mundial de Saúde, de $1948^{6}$, e posteriormente, no brasileiro, a Constituição Federal de 1988, representaram a legitimação do direito sanitário, um novo conceito de saúde e os princípios para a construção dos direitos e deveres, públicos e privados, em vigor hoje (DALLARI, S. G.; NÚNES JÚNIOR, 2010).

A concepção mais ampla que se tem do conceito de saúde, associa-o a uma gama mais extensiva de direitos que, segundo a definição contida no preâmbulo da Constituição da Organização Mundial da Saúde, elaborada em 19467 , compreende: "saúde como o estado de completo bem-estar físico, mental e social e não meramente a ausência de doença ou enfermidade ${ }^{8 "}$ (WORLD HEALTH ORGANIZATION, 1958).

\footnotetext{
${ }^{5}$ Galvão destaca, em "O Tratado de Saúde Coletiva", o desenvolvimento da Bacteriologia e Microbiologia, baseados em aspectos experimentais, que contribuíram para o questionamento dos saberes tradicionais, como a teoria dos miasmas, em voga nos grandes centros capitalistas.

6 Encontra-se, frequentemente, referência a duas datas atribuídas à Constituição da Organização Mundial da Saúde, posto que em 1946 foi realizada a elaboração do texto, vigorando apenas a partir de 1948.

7 Data de elaboração do texto original, em 19 de junho de 1946, assinada em 22 de julho de 1946, com representantes de 61 estados membros.

${ }^{8}$ Tradução da versão original (em inglês) de "Health is a state of complete physical, mental and social well-being and not merely the absence of disease or infirmity" trecho retirado da Constitution of the World Health Organization.
} 


\section{B. A SÁUDE NAS CONSTITUIÇÕES BRASILEIRAS}

As construções históricas, sociais, políticas e conceituais do campo da saúde, no Brasil, perpassam pelas dimensões do desenvolvimento médico-científico no país, suas influências externas e suas peculiaridades internas, pelas perspectivas histórico-culturais, pelo campo da militância social, resistência e luta por direitos, bem como, pela feitura das leis no Parlamento, que regulam seu caráter legal, sua dimensão e sua obrigatoriedade.

Segundo Carvalho et al (2001), a história da saúde pública brasileira pode ser compreendida, a partir de quatro momentos: o sanitarismo campanhista (início do século XX até 1945), cuja principal estratégia de atuação eram as campanhas sanitárias; o de transição (período de 1945 a 1960) de passagem para o período seguinte; o modelo médico assistencial privatista (até o início da década de 80 ) e o modelo liberal (dias atuais) que inclui como sistema público, o SUS.

Sob o aspecto histórico, no período colonial, inexistia, no Brasil, um sistema de saúde formalmente estruturado. As ações de saúde, ainda incipientes, eram de caráter focal, utilizando-se, frequentemente, a medicina de "Folk"." Isso, contudo, não se referia à totalidade da população, a elite local tinha acesso a profissionais trazidos de Portugal para atendê-los. (BERTOLOZZI; GRECO, 1996).

A primeira Constituição do Brasil, já como país independente, data de 1824. Trata-se, quanto a sua vigência, do texto constitucional com a maior duração ${ }^{10}$ dentre as sete Constituições brasileiras - de 1824 a 1889, quando foi revogada (NOGUEIRA, 2015). Com a dissolução da Assembleia Constituinte pelo Imperador, o projeto foi redigido por membros do Conselho de Estado ${ }^{11}$. Uma das principais características desta carta magna foi a quadripartição do poder político em Poder Legislativo, Poder Moderador, Poder Executivo e Poder Judicial. Almejava-se, com o texto constitucional, concentrar poder na figura do Imperador, reforçando-se o cenário das oligarquias. Nesse contexto, a temática da saúde fica em plano inferior.

\footnotetext{
${ }^{9}$ Do inglês Folk (tradição, povo, tribo). Termo utilizado nos estudos antropológicos sobre a saúde, refere-se à medicina popular (tradicional) ligada aos saberes seculares e sagrados como xamanismo, o benzimento, a fitoterapia e outros.

${ }^{10}$ Segundo Nogueira (2015), o que assegura a eficácia de um documento constitucional é justamente a sua longevidade. Nas últimas décadas, o Brasil teve cinco Constituições, com uma duração média de, aproximadamente, dez anos para cada texto constitucional (NOGUEIRA, 2015 - coleção Constituição de 1834).

${ }^{11}$ Durante o Império do Brasil, foram criados 3 Conselhos de Estado. O segundo (de 1823 a 1834) foi fundamental na elaboração da Constituição de 1824, com uma composição variada, contando com 10 membros, dentre eles juristas, matemáticos, um filósofo e um militar de carreira.
} 
Ainda que se buscassem, nesta Constituição, ideais libertários, as grandes e difíceis desigualdades sociais não permitiram sua concretização. Apenas no art. 179, com 35 incisos sobre os direitos e garantias, é que se apresentou a inviolabilidade dos direitos de liberdade, igualdade, segurança individual e propriedade (RIBEIRO; JULIO, 1988).

Em seu inciso XXIV, o artigo 179 da Constituição do Brasil de 1824, previu que: "nenhum genero de trabalho, de cultura, indústria ou commercio póde ser prohibido, uma vez que não se opponha aos costumes publicos, à segurança e saude dos cidadãos". Observa-se, que a alusão à saúde se refere, claramente, às questões do trabalho, garantir-se a atividade laboral e não propriamente a saúde da população em seu sentido amplo. Ainda que fossem previstos os direitos fundamentais à saúde, tais direitos estariam voltados às classes dominantes, ou seja, aos grupos oligárquicos que ainda vigoravam no Brasil, tão vinculado, ainda, à cultura escravocrata e às condições desumanas de vida de grande parte de sua população (ASSEMBLEIA NACIONAL CONSTITUINTE, 1824).

Destacaram-se no período republicano as incipientes e crescentes correntes migratórias, que aliadas à falta de estrutura das cidades brasileiras, às difíceis condições sanitárias, e às diminutas ou ausentes políticas sociais e de saúde, resultaram condições propicias a uma eclosão de epidemias, como a febre amarela $^{12}$ e a peste bubônica ${ }^{13}$. Esse período representou significativo passo para a construção do sentido de saúde pública que temos hoje. Agregaram-se às correntes vigentes, o pensamento do Sanitarismo, engendrada pela vida urbana das cidades, dos portos e transportes. Eram, contudo, medidas pontuais, sob a forma de campanhas, para controlar surtos da época; sanados, logo eram esquecidas. Nesse contexto, iniciou-se a construção da prática médica, que vigoraria no Brasil (BERTOLOZZI; GRECO, 1996).

Contudo, na contramão desse cenário, a Constituição de 1891, a segunda do país, não tratou especificamente do tema saúde. Em seu artigo 72, encontramos uma referência às garantias e aos direitos, no qual se assegurava os direitos de liberdade, segurança e propriedade, bem como, os direitos de reunião, associação e o "habeas corpus", cabe ressaltar, no entanto, que o país encontrava-se fortemente

\footnotetext{
${ }^{12}$ Doença infecciosa grave, causada por vírus e transmitida por vetores, proliferada, principalmente, em área urbana, sem condições sanitárias adequadas (domicílios com acúmulo de água).

13 Conhecida popularmente como a "peste negra" é uma doença pulmonar ou septicêmica e infectocontagiosa.
} 
ligado ao coronelismo, fato que colava em cheque a garantia de acesso aos direitos de liberdade. Pouco houve de reforma neste texto constitucional, dado a dificuldade de aprovação de emendas (de 76 propostas, apenas 5 foram aprovadas) para dificultar o seu uso contra o poder político da época (RIBEIRO; JULIO, 1988).

Sobre a história social da saúde, suas ideias e autores, as primeiras décadas do período republicano adquiriram, segundo Luz (1982), características mais marcantes, com mudanças significativas na sociedade, desde a queda do modelo escravagista até a "hegemonia nacional do capitalismo". Nesse cenário, temos um momento de efervescência da medicina, com a descoberta de cura para as doenças e as primeiras empreitadas sanitaristas, com figuras ilustres na jornada pela legitimação da saúde pública, com as descobertas de Pasteur, na Europa, e as conquistas de Oswaldo Cruz, no Brasil.

Tratou a Constituição de 1934, a terceira do país, engendrada logo após as revoluções de 1930 e 1932, no inciso II do artigo 10, o tema saúde como sendo de competência concorrente da União e dos Estados. Destaca-se, nesta Constituição, o intuito de se implantar os direitos sociais no sistema jurídico brasileiro, mesmo que não tenha sido alcançado.

"Art. 10 - Compete concorrentemente à União e aos Estados:

I - velar na guarda da Constituição e das leis;

II - cuidar da saúde e assistência públicas;

(...)" (PORTO, 2012).

Em 1937, um novo texto constitucional é criado, no Governo Vargas, de duração curta e com caráter autoritário, excluindo-se os direitos fundamentais; ainda que fossem garantidos alguns direitos sociais, não se falou em direito à saúde. Cabe ressaltar, que o texto prevê no inciso XXVII do art. 16, que caberia à União legislar privativamente sobre as normas de defesa e proteção da saúde, sobretudo, a saúde da criança (RIBEIRO; JULIO, 1988).

"Constituição dos Estados Unidos do Brasil (1937):

Art. 16. Compete privativamente à União o poder de legislar sobre as seguintes matérias:

(...) XXVII - Normas fundamentais da defesa e protecção da saúde, especialmente da saúde da creança". (PORTO, 2012).

O necessário resguardar da 'saúde' nas normas jurídicas gerais - as Constituições do Brasil - ocorreu apenas, incipientemente, na $5^{\text {a }}$ Constituição do 
Período Republicano, a Constituição dos Estados Unidos do Brasil, de 1946. A ação legiferante, nesse contexto, preservou aspectos sanitários ligados ao trabalho e, timidamente, tratou da atuação da União e das garantias individuais. Havia, contudo, a noção de que a melhora na saúde, educação e bem-estar econômico levariam, consequentemente, ao desenvolvimento geral da nação (BALEEIRO, A., SOBRINHO, B. L., 2015, p. 13).

Movida pelo ensejo do fortalecimento do Constitucionalismo e dos Direitos Fundamentais, a Constituição de 1946 foi criada no pós 2a ${ }^{a}$ Guerra Mundial, apropriando-se da incipiente inovação do texto constitucional de 1891 e agregando os direitos econômicos, culturais e sociais. O texto constitucional de 1946, apesar de não fazer menção direta aos direitos sanitários, estabelece em seu artigo $5^{\circ}$ (inciso $\mathrm{XV}$ ) que seja de competência da União legislar sobre normas gerais de defesa e proteção da saúde, versando, ainda, sobre as liberdades individuais, a justiça, o trabalho digno e a educação alinhada à solidariedade humana. Ainda que não tenha a Carta Magna se apoiado, significativamente, no debate do Constitucionalismo que ocorria na Europa, ao pensar na proteção da pessoa humana, a Constituição Federal de 1946 apresenta grandes avanços, sobretudo, ao pensarmos que o Brasil acabara de sair de um regime autoritário e o contexto internacional estava recémsaído de uma guerra mundial (DALLARI, S. G., 1988).

No mesmo ano da edição da carta constitucional, a Organização Mundial de Saúde (OMS) estabeleceu, de maneira inovadora, o novo conceito de "saúde" na Constituição da Organização Mundial de Saúde de 1946, com as garantias legais do direito à saúde de maneira mais ampla e irrestrita, atingindo todo o ser humano, sem distinção de raça, credo político, religião e qualquer fator econômico, colando em foco o melhor estado de saúde possível de se atingir, ligando a saúde aos direitos sociais (NETO, 2014).

Durante o golpe militar de 1964, foi promulgada a Carta Constitucional de 1967, na qual se limitava as liberdades alcançadas no texto constitucional anterior, a fim de se implantar um regime autoritário, baseado na doutrinação da segurança nacional. Para tanto, no Ato Institucional de $n^{\circ}$ 4, convocou-se uma nova Constituinte para ficar a cargo de elaborar o novo texto. A questão da saúde, mais uma vez, foi negligenciada, limitando-se um capítulo a tratar dos Direitos e Garantias Fundamentais, que ficariam ainda a cargo da União, conforme previsto na Constituição de 1946. Apenas em 1969, através da Emenda Constitucional no 1, foi 
estabelecido em seu artigo 25 (parágrafo $4^{\circ}$ ) que os municípios aplicassem 6\% do repasse da União na área da saúde (RIBEIRO; JULIO, 1988). Destaca-se, a reserva de recursos públicos, previstos na Constituição, à saúde.

Marco determinante na consolidação dos direitos à saúde no Brasil, a Constituição Federal de $1988^{14}$, carta magna dirigente (TOJAL, 2003), cujo objetivo é a transformação social ${ }^{15}$, representou avanços ao apresentar, pela primeira vez, com grande participação da sociedade civil, o tema de maneira efetiva no texto constitucional. Quanto à obrigatoriedade com saúde, a Constituição da República de 1934 sugeria, timidamente, a possibilidade de conferir a competência, concorrente, de cuidar da saúde à União e aos Estados (DALLARI, S. G., 2009).

A 'saúde', enquanto 'direito de todos e dever do Estado', surgiu na Constituição, de fato, apenas em 1988 - fruto de um amplo debate e de sucessivos avanços na compreensão dos próprios direitos sociais no país. O movimento da Reforma Sanitária Brasileira e a criação de entidades - como o CEBES e a ABRASCO - foram fundamentais para a construção do imaginário sanitário a ser alcançado e, em grande parte, responsáveis por sua ressonância na Assembleia Nacional Constituinte de 1987-88, que resultou, anos mais tarde, na criação do Sistema Único de Saúde e em novas perspectivas de 'saúde'.

Na obra "Os caminhos da saúde pública no Brasil", delineia-se o processo histórico e gradual de consolidação do direito à saúde. É possível apreender os avanços decorrentes da nova Constituição Federal, dos quais destacamos: I) criação do SUS, o Sistema Único de Saúde, concebido nos princípios da universalidade, integralidade e solidariedade; II) maior atenção à saúde nas "Américas"; III) redefinição do papel do Estado, descentralização e o federalismo; IV) compromissos com a melhoria do serviço público e a distribuição de renda; e o V) desenvolvimento e consolidação dos SILOS, Sistemas Locais de Saúde (FINKELMAN, 2002).

A inovação das prerrogativas e garantias preconizadas pela Constituição de 1988 e, especificamente, com a implantação do SUS, segundo Filkelman (2002), é "geralmente entendida como a mais bem-sucedida reforma da área social empreendida sob o novo regime democrático". Cabe salientar, que vivemos, ainda,

${ }^{14}$ Concebida na redemocratização, após a Ditadura Militar de 1964, a Constituição Federal de 1988 ganhou forte acento "garantista", após longo período de cessação de direitos sociais;

${ }^{15} \mathrm{O}$ tema é a abordado pelo Prof. Dr. Sebastião Botto de Barros Tojal da Faculdade de Direito da USP, ao buscar o caráter determinante do texto constitucional. Considera-se a Constituição Federal de 1988 "dirigente", pois estava atrelada à grande transformação social e à ampla garantia de direitos. 
um déficit de efetividade de vários direitos, inclusive o direito à saúde (OLIVEIRA, 2015).

A partir da absorção da responsabilidade de cuidar da saúde assumida pelo Estado, várias foram as leis criadas para organizar a oferta e serviços de saúde, posto que caiba ao ente estatal fazer apenas aquilo que the reza a lei. O direito sanitário, amplamente avocado neste novo contexto, acirrou as exigências por uma nova posição do Estado ante a assumir a responsabilidade pela promoção, proteção e a recuperação da saúde (DALLARI, S. G., 1988).

Nesse contexto, tornou-se imprescindível enveredarmos nossos olhares para a construção das Constituições do Brasil, a fim de compreendermos os caminhos, interesses e conquistas alcançadas pela saúde como marco legal. O Parlamento como responsável pela feitura destas leis foi o foco desta análise, através do perfil de seus membros (profissional, partidário e regional). Neste aspecto, a ANC de 1946 representou o início da jornada sanitarista no Parlamento, enquanto a ANC de 198788 constituiu o mais completo arcabouço de reconhecimento e garantias do direito sanitário, enquanto norma jurídica e concepção cidadã.

A seguir, apresentamos o Quadro Comparativo: Constituições do Brasil Independente (1824 a 1988). 
Tabela 1: Quadro Comparativo: Constituições do Brasil Independente (1824 a 1988) ${ }^{16}$

\begin{tabular}{|c|c|c|c|c|c|c|c|c|c|c|}
\hline \multicolumn{11}{|c|}{ CONTITUIÇÕES DO BRASIL - QUADRO COMPARATIVO } \\
\hline \multirow{2}{*}{ Constituição } & \multicolumn{2}{|c|}{ Membros } & \multicolumn{2}{|c|}{ Regime Político } & \multicolumn{3}{|c|}{ Período de Vigência } & \multirow{2}{*}{$\begin{array}{l}\text { Número } \\
\text { de } \\
\text { Emendas }\end{array}$} & \multirow{2}{*}{$\begin{array}{c}\text { Artigos e } \\
\text { Disposições } \\
\text { Transitórias }^{17}\end{array}$} & \multirow{2}{*}{ Funcionamento e Recrutamento } \\
\hline & Deputados & Senadores & Governo & Governante & Início & Fim & Duração & & & \\
\hline
\end{tabular}

$1824^{18}$ $100^{19} \rightarrow$ $88^{20}$ $0^{21}$ Império D. Pedro
1824 1889 $\operatorname{anos}^{22}$

Em 19.06.1822 expediram-se as orientações para as eleições, cujos eleitores e elegíveis eram as elites locais, agrárias e escravistas. A ANC foi implantada em 03.05.1823 e dissolvida em 12.11.1823 por D. Pedro I. A sua conclusão ficou a cargo do Conselho de Estado, pelo imperador indicado.

${ }^{16}$ Baseado nos estudos e arquivos do CPDOC-FGV.

${ }^{17}$ Conforme texto integral publicado em edição do Senado Federal, em 2015.

${ }^{18} \mathrm{~A}$ Constituição de 1824 ficou conhecida como a 'Constituição da Mandioca' em razão de serem considerados eleitores apenas aqueles que possuíssem em renda, ao menos, o equivalente a 150 alqueires de farinha de mandioca. Ou seja, reafirmavam-se as elites locais, agrárias e escravistas.

${ }^{19} \mathrm{Em}$ razão de conflitos políticos entre os dois centros de poder (Rio de Janeiro e Lisboa), não se possibilitou a realização de eleições nas províncias de Cisplatina, Piauí, Maranhão e Pará. A Bahia também não conseguiu completar o seu número de representantes, portanto, da ideia inicial de 100 deputados, apenas 88 participaram da ANC.

${ }^{20}$ Rio de Janeiro (8), Bahia (11), Espírito Santo (01), Minas Gerais (20), São Paulo (09), Goiás (01), Pernambuco (12), Ceará (07), Rio Grande do Norte (01), Mato Grosso (05), Alagoas (04), Santa Catarina (01), Rio Grande do Sul (04).

${ }^{21}$ A criação do Senado Federal data de 06.05.1826.

${ }^{22}$ Quanto à vigência é considerada a mais longa, tendo vigorado por 65 anos, até 1889, quando foi revogada.

${ }^{23} \mathrm{O}$ projeto da constituinte a ser apresentado ao 'Congresso Nacional Constituinte' ficou a cargo de uma comissão indicada através do Decreto n’. 29 de 3 de dezembro de 1889, durante o Governo Provisório liderado pelo Marechal Deodoro da Fonseca. O grupo ficou conhecido como Comissão de Petrópolis ou 'Comissão dos 5' e era composto por Joaquim Saldanha Marinho (presidente), Américo Brasiliense de Almeida Melo, Antônio Luiz dos Santos Werneck, Francisco Rangel Pestana e José Antônio Pedreira de Magalhães Castro.

${ }^{24}$ Minas Gerais teria 37 cadeiras; Bahia e São Paulo, 22; Pernambuco e Rio de Janeiro, 17; Rio Grande do Sul, 16; Ceará e Distrito Federal, 10; Pará e Maranhão, 7; Alagoas, 6; Paraíba, 5; Piauí, Rio Grande do Norte, Sergipe, Paraná e Santa Catarina, 4; Goiás, 3; Amazonas, Espírito Santo e Mato Grosso, 2.

25 Três representantes de cada Estado. 
Fonseca

disposições

transitórias

'deputados

0

Rev. 1930

Getúlio
Vargas

1934

$1937 \quad 03$ anos

01

187 artigos -

26

disposições

transitórias

187 artigos,

Elaborada por G. Vargas;

F. Campos; A. Costa; E.

1937

Reis; M. Brandão;

Est. Novo

Getúlio

1937

Vargas

Capanema

e A.

Magalhães

conforme o 'Regulamento Alvim'26. À Câmara, possuir mais de 7 anos como cidadão brasileiro, no Senado, 9 anos, além de ser maior de 35 anos de idade. Sufrágio direto em cada Estado ocorrido em 15.09.1890, com ampla vitória dos republicanos. A 'Comissão dos Cinco' encarregou-se da elaboração dos projetos. 3 foram esboçados e com alterações chegou-se ao anteprojeto final em 23.10.1890, através do Decreto ㄲo. 914-A do Governo Provisório. Caracterizou-se por um viés centralizador e pelo modelo federativo.

Primeira eleição em vigor do novo Código Eleitoral, que possibilitou o alistamento de mulheres e a eleição da primeira mulher nas ANCs. As eleições foram realizadas em 03 de maio de 1933. O Decreto $n^{\circ}$. 21.402 de 1932, do Governo Provisório, criou uma comissão responsável pela feitura do anteprojeto, sob a presidência do Ministro da Justiça, tendo se reunido 51 vezes.

Conhecida como Constituição polaca, dada sua semelhança à carta constitucional da Polônia, foi escrita principalmente por Francisco Campos. A Carta reforçava o poder Executivo, com prerrogativas de indicar autoridades estaduais e interventores. Contextualizada no Golpe de Estado de Getúlio Vargas, a Constituição de 1937 que aumentava os poderes do

\footnotetext{
${ }^{26}$ As eleições do Congresso Constituinte foram regidas pelo Decreto $n^{\circ} .511$, que ficou conhecido como 'Regulamento Alvim' em alusão ao seu organizador, o ministro do Interior, José Cesário de Faria Alvim.

${ }^{27}$ Cadeiras: São Paulo (22), Minas Gerais (31), Rio Grande do Sul (13), Pernambuco (17) e Distrito Federal (10).
} 
chefe do Executivo, foi outorgada pelo presidente.

\begin{tabular}{|c|c|c|c|c|c|c|c|c|c|}
\hline 1946 & 297 & Redemoc. & $\begin{array}{l}\text { Gaspar } \\
\text { Dutra }\end{array}$ & 1946 & 1967 & 21 anos & 27 & $\begin{array}{l}218 \text { artigos - } \\
36 \\
\text { disposições } \\
\text { transitórias }\end{array}$ & $\begin{array}{l}\text { Em 1945, foram realizadas eleições para a ANC, que se } \\
\text { instalou em 1946. A Constituição de } 1946 \text { não contou } \\
\text { com anteprojeto na sua elaboração. Assim, } \\
\text { inicialmente, foi necessária a criação de um projeto } \\
\text { para aprovação do plenário e a criação de um novo } \\
\text { regimento. Foi criada uma comissão responsável pela } \\
\text { elaboração do projeto com } 37 \text { membros. }\end{array}$ \\
\hline 1967 & $\begin{array}{ll}\text { Elaborada por L. } \\
\text { Carneiro; M. Fagundes; } \\
\text { O. Nonato e T. Cavalcanti }\end{array}$ & Rev. 1964 & $\begin{array}{l}\text { Castelo } \\
\text { Branco }\end{array}$ & 1967 & 1969 & 02 anos & - & $\begin{array}{l}189 \text { artigos, } \\
\text { incluindo } \\
\text { disposições } \\
\text { transitórias }\end{array}$ & $\begin{array}{l}\text { Foram realizadas eleições para o Congresso Nacional } \\
\text { em 1966. Em clima de instabilidade política, a ANC } \\
\text { buscava apresentar normalidade e dar respaldo ao } \\
\text { golpe militar de } 1964 \text {. Porém, o texto fora concebido por } \\
\text { um grupo. }\end{array}$ \\
\hline $\begin{array}{l}\text { EMENDA № } \\
1 \text { de } \\
30.11 .1969\end{array}$ & Junta Militar & $\mathrm{Al}-5$ & $\begin{array}{l}\text { Garrastazu } \\
\text { Médici }\end{array}$ & 1969 & 1987 & 18 anos & 26 & - & $\begin{array}{l}\text { Em 30.11.1969 entrou em vigor a Emenda №. 1, } \\
\text { decretada pela Junta Militar, alterando profundamente a } \\
\text { Constituição de } 1967 \text {. }\end{array}$ \\
\hline 1988 & 512 & Redemoc. & José Sarney & 1988 & - & $\begin{array}{l}30 \text { anos } \\
\text { (até } \\
\text { agora) }\end{array}$ & $99^{28}$ & $\begin{array}{l}245 \text { artigos - } \\
70 \\
\text { disposições } \\
\text { transitórias }\end{array}$ & $\begin{array}{l}\text { Eleições Diretas (1982 e 1986). Realizada no período } \\
\text { de redemocratização do país, ficou conhecida como } \\
\text { Constituição Cidadã. Seus trabalhados foram divididos } \\
\text { em comissões e contou com grande participação da } \\
\text { sociedade civil. }\end{array}$ \\
\hline
\end{tabular}

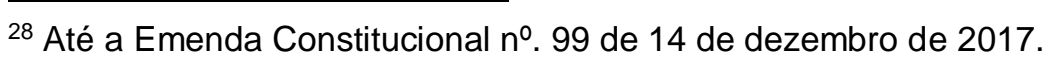




\section{O DIREITO À SAÚDE E AS CONSTITUIÇÕES}

A noção de saúde infere, certamente, na construção do direito a ela atrelada. Observe-se, por exemplo, a nova conceituação empregada em 1946 pela Organização das Nações Unidas. No Brasil, sobretudo, a partir da década de 70, percebe-se que a literatura se ateve ao fenômeno do Direito Sanitário, frequentemente, relacionando-o conceitualmente à noção de saúde. Sueli G. Dallari (1988, 1992, 2005, 2009, 2013), por exemplo, possui amplo estudo acerca dos fundamentos históricos que forjaram este emergente campo jurídico.

Notoriamente, no arcabouço das lutas e conquistas que permearam o reconhecimento da saúde como um direito, o campo emergente do Direito Sanitário requereu a sua criação como parte específica da ciência jurídica. Como bem assegura Fernando Aith, essa nova realidade no ordenamento jurídico tornou-se indelével, dado a sua importância no Estado de Direito brasileiro, voltado à promoção, proteção e recuperação da saúde no país, assim, define-o, em sua Teoria Geral, como "conjunto de normas jurídicas, que tem por finalidade a concretização do Direito humano fundamental à saúde". (AITH, 2006).

A reivindicação do direito à saúde, contudo, é algo moderno. Segundo Dallari, há uma variedade de significados concernentes à expressão direito à saúde, dado, sobretudo, à imprecisão do próprio conceito de saúde. Seguindo, apenas, a definição da Organização Mundial de Saúde, teríamos, com sua amplitude, dois núcleos de definição, um básico e outro mais completo. Saúde, pela OMS, seria tanto a ausência de doença - núcleo básico do conceito como também, o completo bem-estar físico, mental e social - o que Dallari classificou como "halo nebuloso". (DALLARI, S. G., 1988).

A definição de Direito Sanitário requereria, portanto, a identificação do conjunto de normas que contemplassem esse núcleo básico - ausência de doença - bem como, o núcleo mais completo, com bem-estar físico, mental e social. Uma tarefa difícil é, ainda, separar as regras específicas do Direito Sanitário das demais, que visem igualmente melhorar a condição social dos 
indivíduos. Esse campo, portanto, é parte do direito social, assim como o direito ao trabalho e da segurança social, exemplifica S. Dallari. (ibid, 2008).

Poderíamos, ainda, segundo Fernando Aith, incluí-lo no que se convencionou chamar de Direitos Humanos de segunda geração. Também, na Constituição Federal de 1988, o direito à saúde aparece (C.F., art. 6º) expressamente com direito social. E, como tal, requer do Estado brasileiro "ações concretas e efetivas para a promoção, proteção e recuperação da saúde". O Estado deve, assim, intervir na dinâmica social, a fim de garantir a proteção do direito à saúde (construção de hospitais, programas de vacinação, contratação de médicos). (AITH, 2006).

De fato, o direto à saúde enquanto dever do Estado não foi tema específico das Constituições brasileiras anteriores, aparecendo significativamente, apenas, na Constituição Federal de 1988. Antes disso, a Constituição da República dos Estados Unidos do Brasil, promulgada em 16 de julho de 1934, tratou tangencialmente do tema, conferindo a possibilidade de os estados atuarem na saúde, concorrente à União. Além disso, abordou, também, uma preocupação em restringir a mortalidade e morbidade infantil, bem como conter a propagação de doenças transmissíveis e "cuidar da higiene mental e incentivar a luta contra os venenos sociais (art. 138, $f$ e $g$ )". E um pouco mais significativamente na Constituição de 1946 (DALLARI, S. G, 2009).

No campo da Teoria Constitucional, segundo Pontes de Miranda (1953), o ramo do Direito Público responsável por fixar os fundamentos estruturais do Estado, denomina-se Direito Constitucional:

"O que nele entra e o que nele não entra é questão que não se decide a priori. Depende, em grande parte, de certas condições sociais, notadamente da simples inclusão, ou não-inclusão, na Constituição ou nas leis reputadas 'constitucionais'. Aliás, o fato de se consignar nos seus textos algum princípio, ainda que básico, de uma instituição não torna 'constitucional' toda a instituição. Por outro lado, a técnica legislativa dos nossos dias dispõe de inumeráveis expedientes de mantença, alusão e referência constitucional a matérias de direito público e de direito privado" (MIRANDA, Pontes. 1953, p. 129).

Pontes de Miranda (1953) define Constituição como 'ato do poder estatal' estabelecido através do poder constituinte, que persiste na 
continuidade da ordem jurídica, renovada a cada Constituição. Mudar-se-á esse poder em razão da ação do poder estatal (a vontade de alguns que se tornará a vontade de povo) ou mesmo pela mudança 'radical' da opinião política do povo. Por quanto persista a vontade atual, com a vontade inicial da elaboração da lei, a Constituição permanecerá, até que ocorra a divergência dessa vontade e a ação de renová-la. Tratamos aqui do Direito Constitucional aquele imediato do Estado, "que dá vida e norma aos órgãos do Estado, que os cria e disciplina” (MIRANDA, P. 1953. p. 138).

Para Pontes de Miranda (1953) "toda Constituição contemporânea precisa ser obra meditada, profunda, de ciência política e de arte política, de ciência jurídica e de técnica jurídica” (ibid. 1953. p. 140).

Em seus "Comentários à Constituição de 1946", Pontes de Miranda (1953), na seção III, destina-se à 'técnica das Constituições'. As Constituições, segundo Pontes, devem possuir objetivo próprio, o que não requer que sejam sempre os mesmos, nem que predeterminem matérias especificamente obrigatórias. O que se espera "é que elas exigem mínimo de discriminação do que pode o círculo social mais largo, ou se só ele pode (unitarismo puro), e apontam onde reside o poder estatal e quem faz a lei, inclusive a própria reforma constitucional". A isso, Pontes considera o cerne do Direito Constitucional (ibid. p. 150).

Pontes de Miranda (1953) ressalta que nem tudo cabe no texto constitucional. A Constituição, cientificamente, pode ser "precisa de muito pouco: de simples princípio de ordem que seja o ponto de apoio em que se possam firmar os grupos e os indivíduos para se conferir ou se impor aos fatos políticos (ou políticos e econômicos, ou sociais de outra natureza) certa juridicidade básica (ibid. p. 151).

$\mathrm{Na}$ perspectiva positivista ${ }^{29}$ do direito de Hans Kelsen (1881-1973), importante jurista e filósofo austríaco, célebre elaborador da Teoria Pura do Direito - cujo objetivo principal era encontrar a essência do direito nele mesmo

\footnotetext{
${ }^{29}$ Refere-se ao Positivismo Jurídico ou Juspositivismo, teoria que rejeita o Jusnaturalismo no Direito, centrando-se no próprio direito, independente de outros fatores, cujo Hans Kelsen fora um dos seus expoentes.
} 
- evidencia-se a preocupação do direito em regular a sua própria criação, ou seja, o processo no qual uma norma determina a criação de outra, algo superior cujas demais leis estão ligadas, o seu fundamento imediato de validade. Estabelece-se, assim, segundo Kelsen, a norma superior, donde se originam as demais, denominadas normas inferiores. Nesta interpretação, a norma maior determina os limites do poder legiferante sobre a norma menor, e em certa medida, até mesmo o seu conteúdo. Nessa escalonação, diz Kelsen (ibid., 1997, p. 155):

"A ordem jurídica não é um sistema de normas jurídicas ordenadas no mesmo plano, situadas umas ao lado das outras, mas é uma construção escalonada de diferentes camadas ou níveis de normas jurídicas" (KELSEN, H., 1997, p. 155).

Se o Direito impõe essa dinâmica, onde uma norma é criada e validada sobre a salvaguarda de outra superior, temos, em última instância, uma norma fundamental. Segundo Kelsen, essa norma tal elevada no último escalão do Direito positivo, é justamente a Constituição, donde se regulam as normas jurídicas gerais (ibid., 1997, p. 155).

As Constituições - esse conjunto de normas que regem a produção do direito - podem ser classificadas, segundo a teoria da Constituição kelseniana, em materiais ou formais. Ocupemo-nos, aqui, das materiais. Essas, por sua vez, podem originar-se via consuetudinária (não escrita) - produzida pelo costume; ou através do ato de um ou mais indivíduos - um ato legislativo (escrita). Constituindo-se por um ato legislativo, resulta-se sempre em um documento escrito, que condensa suas disposições, com caráter vinculante (ibid., 1997, p. 155).

Kelsen (1997) distingue ainda os aspectos formais na classificação de uma Constituição escrita. Nessas se encontram não apenas as normas que regulam a produção das normas gerais (legislação: leis e decretos) que falávamos anteriormente, mas também normas concernentes a outros assuntos politicamente importantes - as leis constitucionais - que se diferem das demais leis, posto que sua extinção requeira processos mais rigorosos e severos. Esses preceitos garantem maior estabilização da Constituição e do próprio 
Estado. Explica Kelsen: "Quer isto dizer que a Constituição prescreve para a sua modificação ou supressão um processo mais exigente, diferente do processo legislativo usual; que, além da forma legislativa, existe uma específica forma constitucional" (ibid., 1997, p. 155-157).

A teoria da Constituição de Hans Kelsen aborda, ainda, a questão da inconstitucionalidade. Uma "lei inconstitucional", segundo Kelsen, já se apresenta enquanto um contradictio inadjecto - terminologia romanística à contradição de termos - posto que a premissa para criação de uma lei seja justamente a sua constitucionalidade. Ao posto que uma lei possa ser alterada por outra lei ou revogada conforme a Constituição - enquanto vigorar preservase sua constitucionalidade (ibid., 1997, p. 189).

Ferdinand Lassalle (1825-1864), economista polonês, abordou o aspecto sociológico das Constituições, produzindo duas importantes obras sobre 0 tema, a saber: "A essência da Constituição" e "O que é uma Constituição30?". A indagação inicial - O que é uma Constituição? - é sugestivamente apresentada na obra questionando hipoteticamente a um jurisconsulto. A possível resposta, transcrevemos a seguir: "Constituição é um pacto juramentado entre o rei e o povo, estabelecendo os princípios alicerçais da legislação e do governo dentro de um país" (LASSALLE, 1993, p. 07).

Em geral, segundo Lassalle (1993), as respostas a sua indagação recaiam em descrever exteriormente as Constituições ou a explicar suas funções. Para além, Lassalle busca o que denomina "essência da Constituição". A Constituição "é a fonte primitiva da qual nascem a arte e a sabedoria constitucional". Para explicá-la recorre ao seguinte método: "compararmos a coisa cujo conceito não sabemos com outra semelhante a ela, esforçando-nos para penetrar clara e nitidamente nas diferenças que afastam uma da outra" (ibid., 1993, p. 08).

Nessa linha, Lassalle compara lei (em tese algo conhecido) e Constituição (o que se quer conhecer). Para tanto, explicita afinidades e

\footnotetext{
${ }^{30} \mathrm{Em}$ algumas traduções utiliza-se o título "O que é uma Constituição política", noutras suprimese o termo "política" - utilizaremos, aqui, usualmente o enunciado "O que é uma Constituição" cuja opção é a mesma da edição escolhida.
} 
desassemelhanças - tanto as leis quanto as Constituições são regidas com a aprovação legislativa - uma semelhança. Todavia as Constituições não são simples leis, criadas e alteradas constantemente. Em muitos países, quando alteradas suas Constituições, há grande mobilização social favorável ou contrária e não são atos costumeiros - uma desassemelhança. $O$ autor ressalta a disposição necessária, na maioria dos países para uma alteração constitucional, em geral, composta por dois terços de votos ou mesmo por uma nova assembleia constituinte exclusiva para tal fim. Prossegue o autor: "(...) todos esses fatos demonstram que, no espírito unânime dos povos, uma Constituição deve ser qualquer coisa de mais sagrado, de mais firme e de mais imóvel que uma lei comum" (ibid., 1993, p. 09).

No caso brasileiro, por exemplo, as PEC (Propostas de Emenda à Constituição) que são proposições de alteração ao texto constitucional, necessitam - quando iniciativa dos parlamentares - da assinatura de no mínimo um terço dos membros da casa, ou seja, ao menos 171 deputados para serem recebidas e processadas, sendo aprovada apenas com 3/5 dos votos. As propostas podem, ainda, originarem-se nas Assembleias das unidades da federação ou enquanto proposta da Presidência da República. Excetuam-se de propostas de emenda as chamadas cláusulas pétreas - que não podem sofrer alteração dado seu caráter basilar na CF: (I) a forma federativa; (II) o direito universal de escolha de nossos representantes; (III) a independência e harmonia dos poderes; e (IV) os direitos e garantias fundamentais dos cidadãos. (PACHECO, L. B. 2013, p. 28-29).

\section{A REPRESENTAÇÃO}

Decorrente do nosso modelo constitucional, está incontornavelmente o sistema político-eleitoral. Evidentemente, quando falamos em 'voto' e 'escolha' estamos tratando, nesse sistema, da 'representação' - algo muito mais complexo do que atribuir a alguém suas prerrogativas. Hanna Pitkin (1972) dedicou-se aos estudos da representação, em seus paradoxos, constituindo 
uma importante reflexão na teoria política. Partimo-nos do significado, segundo a autora, de 'representação':

\begin{abstract}
"representar (...) significa agir no interesse dos representados, de uma forma que se constitua como resposta em relação a eles. $O$ representante deve agir de forma independente; a sua ação deve desenvolver discrição e juízo; deve ser ele quem age. Os representados devem ser (concebidos como) capazes também, de ação e juízo independentes, não como sendo somente protegidos. E, apesar do potencial resultante para a existência de conflito entre representantes e representados, acerca do que é suposto fazer, esse conflito não deve ocorrer normalmente. O representante deve agir de tal forma que não haja conflito ou, se ocorrer, uma explicação é exigida. Ele não deve estar persistentemente em dívida com os desejos dos representados sem que haja uma boa razão no que respeita aos seus interesses; sem que haja uma boa explicação do porquê de os seus desejos não estarem de acordo com os seus interesses" (PITKIN, 1967, p. 90-91).
\end{abstract}

O primeiro aspecto que pode-se destacar no excerto acima é que a relação representante-representado prevê a ação independente de ambos, porém com 'sincronicidade de desejos'. Na analogia às disputas eleitorais, poderíamos refletir sobre a relação 'promessas-ações' no período eleitoral e a atuação dos parlamentares nos mandatos. Esse conflito de interesses muitas vezes é amenizado pelo distanciamento do processo político, o que não descarta um descontentamento amplo com a classe política, justamente pela dissonância entre a ação política dos eleitos e seus eleitores. O que Pitkin identificou foi "a impossibilidade lógica de que, na esfera de poder, haja identidade de vontade entre representante e representado" (CORVAL, 2015, p. 245).

Segundo Pitkin (1972), a representação na teoria política pode ser interpretada de vários sentidos: a representação como forma, descrição, símbolo e ação; a representação como correspondência com o todo; e representação como ação em nome de outrem. O que mais tarde (1989) a autora traduziu em 'paradoxos da representação'. Analisaremos a seguir a reconstrução feita por Corval (2015) do pensamento de Pitkin. 
Pitkin (1969) traça um percurso histórico do sentido de 'representação'. Houve época em que não existia esse sentido. Os gregos, por exemplo, não possuíam esse conceito em sua linguagem, inexistindo em seu idioma alguma palavra que o descrevesse - as instituições, por sua vez, também não tinham esse papel na vida política dos gregos: "as vezes eles enviavam um indivíduo para falar em nome de um grupo organizado, por exemplo, um embaixador enviado de uma pólis para outra", mas ainda sim o modo grego de pensar não contemplava, nessa época, a noção de representação em um único conceito. Os romanos, de outro lado, utilizam o verbo 'repraesentare', que significava "fazer presente, manifestar ou apresentar pela segunda vez" e se referia exclusivamente aos objetos inanimados, ou seja, em "em nada se aproximada da ideia de pessoas representares outras pessoas, ou o Estado romano" (PITKIN, 1969).

O conceito de representação - e as instituições ao modo que conhecemos hoje - começaram a surgir apenas na Idade Média, houve uma expansão daqueles conceitos iniciais (reapresentare) pelo campo religioso. $O$ papa e os cardeais eram vistos enquanto representares de Cristo e dos Apóstolos. Ainda a Idade Média, "presenciou o desenvolvimento, em muitas partes da Europa, das primeiras instituições de representação política". Reis e papas instituíram conselhos consultivos. Na Inglaterra, o Conselho dos Lordes inicia-se, a priori, como "algo administrativo e politicamente conveniente ao rei". O Parlamento não era constituindo, ainda, como 'legislativo', encarregado de fazer leis (ibid, p. 10).

Contudo, para Pitkin, "o passo final em direção ao nascimento da ideia moderna de representação através de um agente e à ideia de agir por outros, $e$ ligando as instituições à democracia e às questões de Direito - foi dado no século XIX". A representação enquanto um dos direitos tradicionais dos ingleses tornou-se algo pelo qual almejava-se lutar, constituindo-se um dos "Direitos Universais do Homem". A institucionalização desse direito trouxe para a sociedade o desafio de introduzir instituições representativas, onde não 
existiam, ampliar o sufrágio, e tornar de certa maneira os governos responsáveis perante os representados. Nesse ensejo, segundo a autora:

"Na medida em que o governo e a política são considerados como meio, um disposto prático para promover os interesse essencialmente isolados e privados e para proteger os direitos individuais dos governados, o principal problema parece o de como criar uma máquina de representação realmente eficiente" (ibid, 1969, p. 11).

Certo ponto, Pitkin (1969) traz à luz a grande problemática da representação: "como selecionar os representantes certos, ou como controlar os selecionados de modo que eles respondam efetivamente às necessidades $e$ interesses das pessoas". Nesse preâmbulo, a autora apresenta o paradoxo lógico inerente à relação entre representantes e representados, que sustenta a sua teoria sobre a representação. Segundo Alkmim (2013):

"O paradoxo da representação política pode ser denotada como a impossibilidade de igualdade dos termos da $A=B$, pois na esfera de poder esta igualdade é logicamente impossível, porque um sujeito ou vontade pessoal não pode se expressar através de outro sujeito ou vontade. Desta forma, problemas relativos à participação política seriam reduzidos à gênese da própria representação" (ALKIMIN, 2013, p. 57).

Alkmim (2013) aborda algumas questões inerentes ao paradoxo da representação política:

I - "A formulação lógica da representação política não se sustenta, ou seja, seria impossível $B$ representar A, pois a vontade não se representa;

II - A identidade dos representados não coincide com a identidade dos representantes, do ponto de vista tanto da opinião como da segmentação social;

III - A obscuridade do sufrágio universal secreto, que não pode ser considerado um pacto diretamente formado pelos cidadãos;

IV - Qualquer pacto político firmado não pode ter valor para as gerações seguintes;

$\mathrm{V}$ - O processo político, na forma da representação parlamentar, atende interesses dentro da estrutura de classes da sociedade, mas não é aí o centro da gravidade do poder;

VI - Atomização e serialização do eleitorado como efeito do sufrágio universal, através do voto secreto, dificulta ou impede a formação de uma consciência coletiva, não alienada" (ibid, 2013). 
Stuart Mill em "Considerações sobre o Governo Representativo" apresenta caminhos da ideia de representação na teoria democrática, sustentando uma variável da democracia concernente à qualificação do cidadão, a fim de assegurar-lhe a imersão na esfera pública e "por conta disso, bastante aproximada das correntes participacionistas que percebem e valorizam a democracia como processo educativo" (CORVAL, 2015, p. 246).

Segundo Corval (2015), Stuart Mill:

"Reconhece as verdades em cada perspectiva e sustenta que as instituições constitutivas das formas de governo são artificiais e passíveis de mudança pela ação humana. Todavia, essa mudança é condicionada por elementos contextuais atinentes ao próprio agente político: o desejo de aceitar a forma de governo, o desejo e a capacidade de fazer o necessário para mantê-lo funcionando e o desejo e a capacidade de fazer o que for exigido para atingir os objetivos da forma de governo aceita" (ibid, 2015, p. 263).

O desejo e a capacidade de fazer e não fazer, ou seja, as condições de ação e autocontrole são, para Mill, as virtudes básicas do agente político. " $A$ representação possibilitaria filtrar os elementos sectários e fazer emergir, em cada lado do conflito, aqueles agentes políticos dotados das capacidades morais de coser, pacificamente, em favor do bem-estar geral, as parcialidades de indivíduos e classes" (ibid, 2015, p. 265).

O governo, contudo, não pode ser uma arena única, mas sim um meio de "promoção das finalidades dele esperadas", alcançando seus objetivos pela "promoção do conjunto de qualidades do ser humano que forma a sociedade sobre a qual exercerá o seu poder", essa promoção, segundo Corval, seguindo a agenda democrática, logrará êxito quando incluir os interesses e "pontos de vistas valorativos das mais diferentes pessoas na própria maquinaria governamental" (ibid, 2015, p. 266).

Por fim, Corval (2015) entende que Stuart Mill:

"(...) diferencia a essência do governo representativo das suas formas particulares, conceituando o governo representativo como aquele no qual o povo inteiro ou uma parte numerosa dele exerce através dos 
deputados periodicamente eleitos pelo povo, o extremo poder controlador que, em qualquer constituição, deve residir alguma parte. O governo é apenas um instrumento para a representação; mecanismo que, entretanto, para Mill, à sua época, mostra-se em termos práticos o único viável e, por isso, para ser o mais produtivo possível, carecedor de aperfeiçoamentos funcional (ibid, 2015, p. 267).

Alkimim (2013) inspirado em Hanna Pitkin, traça um modelo de classificação das possibilidades representativas, colocando Stuart Mill no modelo constituído pela "identidade". Trata-se do "modelo descritivo de representação que encontra em John Stuart Mill um dos principais defensores. Baseia-se na identidade ou sintonia entre os elos na relação de representação. A representação é vista como um "retrato em miniatura, mapa, espelho, amostra da população, quanto aos seus atributos sociais, demográficos, segmentos de opinião. Defesa da representação das minorias". 


\section{ASSEMBLEIAS NACIONAIS CONSTITUINTES 1946 E 1987-88}

\section{A. A ANC DE 1946}

Em linhas gerais, a Constituição de 46 representou a consolidação da derrocada da ditadura Vargas e um significativo avanço democrático, através de um texto constitucional, que se tornou importante referência, inclusive à $\mathrm{CF}$ de 1988. Recuperou-se o princípio federativo - valorizando a autonomia de Estados e Municípios, garantiu-se a liberdade de culto, além da "total liberdade de pensamento, limitada apenas no que dizia respeito aos espetáculos e diversões públicas". Restringiu o cerceamento as liberdades e garantias individuais, ao limitar expedientes autoritários e ao reservar unicamente ao Congresso Nacional a aprovação do estado de sítio (BONAVIDES, P. ANDRADE, P. 1991, p. 409).

No campo político, a organização partidária era livre - ainda que houvesse uma ressalva que impedia a criação de partidos ou associações, que contrariassem o 'regime democrático', em seus programas ou projetos. Com importante avanço, estabeleceu-se a ideia de tripartição e equipotência dos três poderes. "Ela buscava desenvolver ao Legislativo e ao Judiciário a dignidade $e$ as prerrogativas características de um regime efetivamente democrático". Linha de pensamento que não logrou êxito nos anos que seguiram. (ibid, p. 409).

Getúlio Vargas foi presidente ininterruptamente por 15 anos, dos quais 8 em regime ditatorial.

"Os jogos e intercâmbios políticos, que tinham seu canal natural de expressão - O Parlamento - coarctados, acabaram por penetrar todas as camadas da burocracia, fazendo com que as decisões políticas ganhassem cada vez mais um caráter intransparente, espesso e incontrolável. O corporativismo alastrou-se por todos os níveis da sociedade. Com isso, o Poder Legislativo tomou ares imperiais, inchando de modo a hipertrofiar o Legislativo e o Judiciário". (ibid, p. 410). 


\title{
1. O PROCESSO CONSTITUINTE
}

\begin{abstract}
"Os benefícios que ao Brasil já trouxe à Constituição de 1946 são grandes. Vê-los-ão maiores os que tiverem de apreciar dentro de alguns decênios. Serviu, além disso, a mostrar a vocação democrática e liberal do povo brasileiro. As dificuldades provêm dos tempos que mediaram entre 1930 e 1945, período de difícil liquidação, tal a atividade de elementos intelectuais e políticos, antidemocráticos, de direito e de esquerda, contra qualquer permanência de ordem constitucional em que se assegurem liberdade e democracia. Pode-se dizer que é o Brasil mesmo que resiste; e ao Congresso Nacional, principalmente ao exercer a sua função de fiscalização é que se há dever o bom êxito da Constituição de 1946. Ainda sem emenda dos textos, pode ele obter a plenitude de sua eficiência, através dos arts. 53,54, 55, 59, 41, IV, 62, I e II, 63, 65, VII, da Constituição de 1946 (MIRANDA, Pontes. 1953, p. 5).
\end{abstract}

A preparação da ANC de 1946 se inicia com as eleições de $1945^{31}$, que resultou em uma ampla representação partidária, embora apenas 15\% da população brasileira tenham comparecido às urnas, o que não permitiu auferir 'segurança' à popularidade de Vargas, ainda que evidente nas classes mais simples. (BONAVIDES, P. e ANDRADE, P. 1991, p. 410).

O PSD contou com maior número de representantes, seguido da UDN e do PTB. A bancada da UDN agregou as candidaturas do PR (comandado pelo ex-presidente Artur Bernardes) e da Esquerda Democrática. Outros partidos, menores, também alcançaram destaque: o Partido Comunista - que elegeu 15 representantes; o Partido Social Progressista - comandado por Adhemar de Barros; e o Democrata Cristão (BALEEIRO, A. 2012. p. 09).

Ao todo foram realizadas duas sessões preparatórias, a Sessão de Instalação da ANC e dez sessões de trabalho.

\section{SESSÕES PREPARATÓRIAS}

Sob a presidência do Ministro Valdemar Falcão, presidente do Tribunal Superior Eleitoral, instalou-se, a ANC de 1946, em $1^{\circ}$ de fevereiro de 1946, em

\footnotetext{
${ }^{31}$ Realizadas em 2 de dezembro de 1945, no pleito foram escolhidos o Presidente da Repúblicas e os constituintes.
} 
Sessão Preparatória, no Palácio Tiradentes, sede da Câmara dos Deputados. Em seu discurso destacou a sua impressão das eleições de 1945 e a importância da ANC, diz:

\begin{abstract}
"É para mim grande satisfação ocupar tão elevado posto, neste momento, após uma eleição em que coube aos Juízes e Tribunais Eleitorais a árdua tarefa de assegurar os direitos de todos os cidadãos e proclamá-los mediante um pleito livre, honesto e disputado, como foi o processo eleitoral de 2 de dezembro último". (ibid, v. 1 p. 3).
\end{abstract}

No dia anterior, 31 de janeiro de 1946, tomava posse o general Eurico Gaspar Dutra no cargo de Presidente da República, conforme relata:

"Ontem empossou-se o Presidente eleito da República, hoje começam a reunir-se os representantes da Nação nesta magna Assembleia para cumprir a tarefa grandiosa de recompor em moldes democráticos o país e dar-Ihe a Carta Constitucional condigna aos destinos do povo brasileiro" (ANAIS, CD, 1946, v. 1 p. 3).

1a SESSÃO PREPARATÓRIA- na primeira sessão, em 01.02.1946, foram apresentadas as considerações iniciais do ministro Valdermar Falcão sobre o processo eleitoral e os ensejos atribuídos ao novo processo constituinte; o projeto de normas regimentais - aquelas que norteariam o funcionamento da ANC, assinado por, entre outros, Carlos Marighela, Luis Carlos Prestes e Jorge Amado; houve algumas questões de ordem, inclusive, intervenções solicitando que a condução imediata do processo fosse transferida a um Senador ou Deputado Constituinte; na ocasião foi apresentado um protesto encabeçado pelo constituinte Carlos Marighela, representando a bancada comunista; um apelo do Dep. João Amazonas à ANC ainda sobre a condução dos trabalhos e, por fim, a chamada dos constituintes e entrega dos diplomas.

2a SESSÃo PREPARATÓRIA - no dia 04 de fevereiro de 1946, realizou-se a Segunda Sessão Preparatória, ainda presidida pelo Sr. Valdermar Falcão. A primeira pauta tratou novamente da questão regimental. Tratou-se, a 
seguir, dos constituintes que não tomaram posse, em virtude de assumirem cargos no Executivo e dos suplentes - relação dos suplentes diplomados; procedeu-se atenção ao requerimento de Café Filho que dispunha sobre o regimento interno, neste sugeria-se a condução dos trabalhos com a utilização do regimento da Assembleia Constituinte de 1933 - transcrevemos, abaixo, as considerações do Sr. Presidente do TSE:

\begin{abstract}
“(...) cumpre-me, na qualidade de Presidente do Superior Tribunal Eleitoral, apenas a função de executar, nesta etapa, os preceitos de lei que regulam, provisoriamente, os trabalhos desta Assembleia. Não poderei submeter à discussão o requerimento, nem fazê-lo objeto de deliberação imediata, na presente sessão, reservando essa formalidade para quando eleito o Presidente da Assembleia". (ibid, p. 22).
\end{abstract}

Procedida a votação, promulgou-se Fernando de Mello Viana, Presidente da ANC de 1946, com ampla maioria de votos (200 votos no universo de 229, em $2^{\circ}$ lugar ficou Luis Carlos Prestes, com 15 votos). No encerramento da sessão, houve o agradecimento ao Ministro do TSE pela condução inicial dos trabalhos e, ainda, a leitura de uma proposição do constituinte João Gomes Martins, em elogio ao presidente do TSE, a fim de que se retirassem o termo "corpo estranho" utilizado anteriormente na ANC por um deputado ao se referir ao magistrado.

Em 05 de fevereiro de 1946, instalou-se a ANC, durante sessão solene. Constitui-se uma mesa provisória, uma vez que apenas o presidente havia sido eleito. Após a chamada dos Constituintes, seguiu-se a discussão em torno do regimento e o Presidente da ANC fez suas considerações. Os constituintes prestaram o compromisso, conforme trecho a seguir:

"Prometo guardar a Constituição Federal que for adotada, desempenhar fiel e legalmente o mandato que me foi confiado e sustentar a união, a integridade e a independência do Brasil". (ibid, p. 32-33).

O partido comunista, também, apresentou as suas propostas ao novo governo e aos constituintes, estabelecendo a sua linha de atuação. 


\section{O PERFIL DO PARLAMENTO}

A evidência do "recrutamento político da saúde ou sanitário", dá-se de diversas maneiras, permeadas pelas questões de interesses e grupos de representação. Buscamos conhecer cada variável:

\section{Tabela 2: Perfil dos Parlamentares}

\begin{tabular}{|c|c|}
\hline Perfil & Características \\
\hline Pessoal & $\begin{array}{l}\text { Constitui-se de dados concernentes a sua vida familiar e } \\
\text { individual, natividade, ascendência e descendência (quanto } \\
\text { relevantes ao estudo), idade e linhagem familiar }\end{array}$ \\
\hline Profissional & $\begin{array}{l}\text { Retrata a atuação profissional }{ }^{33} \text { do Constituinte, exterior as } \\
\text { atividades legislativas, compreendendo, também, a } \\
\text { escolaridade (nível de graduação e formação). }\end{array}$ \\
\hline Político-Partidária & $\begin{array}{l}\text { Aborda, baseado em informações oficiais do Parlamento e do } \\
\text { Tribunal Superior Eleitoral, o partido político }{ }^{34} \text { do constituinte, } \\
\text { bem como, sua atuação formal nas Comissões de Trabalho. }\end{array}$ \\
\hline Regional & $\begin{array}{l}\text { A procedência geográfica circunscreve, significativamente, a } \\
\text { atuação parlamentar, em razão das necessidades e } \\
\text { prioridades regionais de determinada população em seu } \\
\text { território. Isto posto, a "distribuição de alimentos ou o } \\
\text { fornecimento de água" traduz necessidades urgentes de áreas } \\
\text { secas, enquanto "poluição do ar" pode apresentar-se demanda } \\
\text { prioritária das regióes do hemisfério sul. Nesta variável, } \\
\text { portanto, são compiladas as procedências regionais dos } \\
\text { Constituintes, conforme dados fornecidos aos órgãos oficiais. }\end{array}$ \\
\hline
\end{tabular}

\footnotetext{
32 Há, conhecidamente, diversas famílias com larga tradição na política institucional, aliado à presença regionalizada em todos os níveis e poderes, a exemplo, relações de parentesco predominantes entre executivo, judiciário e legislativo. Questão, parcialmente, sanada após a Súmula 13 do Supremo Tribunal Federal, que veda as relações parentais na mesma esfera de poder.

${ }^{33}$ Considera-se a auto-declaração profissional, constante nos registros da Câmara dos Deputados, bem como, salvo raras exceções, conhecimento público de perfil profissional, evidenciado em outras fontes de registros como discursos e jornais. A atividade legislativa, quando assim declarada "profissão", será considerada na ausência de registro outro, sendo destacada tal ocorrência.

${ }^{34}$ Considerar-se-á, sempre, a declaração partidária pelo qual o parlamentar foi eleito à Assembleia Nacional Constituinte, no caso de mudança de sigla, uma vez que retrata a agremiação pelo qual foi eleito.
} 


\section{MESA DA ASSEMBLEIA - COMPOSIÇÃO}

A Mesa da Assembleia foi composta predominantemente por advogados, sob a presidência do Senador Fernando de Melo Viana, do PSD, de Minas Gerais. Nas posições de comando da ANC (presidência, vicepresidência, secretariado e suplente) não houve ocupação por nenhum constituinte proveniente da carreira médica ou outras áreas da saúde. Destacando-se a presença massiva de advogados em mais da metade das posições de comanda da mesa diretora $(55,5 \%)$.

Tabela 3: Composição da Mesa da ANC de 1946

\begin{tabular}{|c|c|c|c|c|}
\hline Constituinte & Função & Partido & Estado & Profissão \\
\hline Sen. Fernando de Melo Viana & Presidente & PSD & MG & Advogado \\
\hline Dep. Otávio Mangabeira & $\begin{array}{l}\text { 10 Vice- } \\
\text { Presidente }\end{array}$ & UDN & BA & Engenheiro \\
\hline Dep. Berto Condé & $\begin{array}{l}2^{\circ} \text { Vice- } \\
\text { Presidente }\end{array}$ & PTB & RJ & Advogado \\
\hline Sen. Georgino Avelino & 1 Secretário & PSD & $\mathrm{RN}$ & Advogado \\
\hline Dep. Lauro Sodré Lopes & $2^{\circ}$ Secretário & PSD & PR & Advogado \\
\hline Dep. Lauro Bezerra Montenegro & 3 Secretário & PSD & PB & Agrônomo \\
\hline Dep. Rui da Cruz Almeida & 4오 Secretário & PTB & MA & Militar \\
\hline Dep. Hugo Ribeiro Carneiro & Suplente & PSD & PA & Advogado \\
\hline Dep. Carlos Marighela & Suplente & PCB & BA & Poeta \\
\hline
\end{tabular}

\section{AS COMISSÕES DA ANC DE 1946}

Depois da elaboração do Regimento Interno, os partidos políticos, através de seus líderes, procederam a indicação de seus representantes junto à Comissão de Constituição, considerada a "Grande Comissão", que contou com 37 membros. As demais comissões foram assim organizadas:

\section{Tabela 4: Organização das Comissões e Subcomissões da ANC 46}

\begin{tabular}{c} 
Comissões e Subcomi \\
\hline I - Comissão de Constituição (“Grande Comissão"): \\
I-a. Subcomissão de Organização Federal \\
I-b. Subcomissão de Discriminação de Rendas \\
I-c. Subcomissão do Poder Legislativo \\
I-d. Subcomissão do Poder Executivo \\
I-e. Subcomissão do Poder Judiciário
\end{tabular}




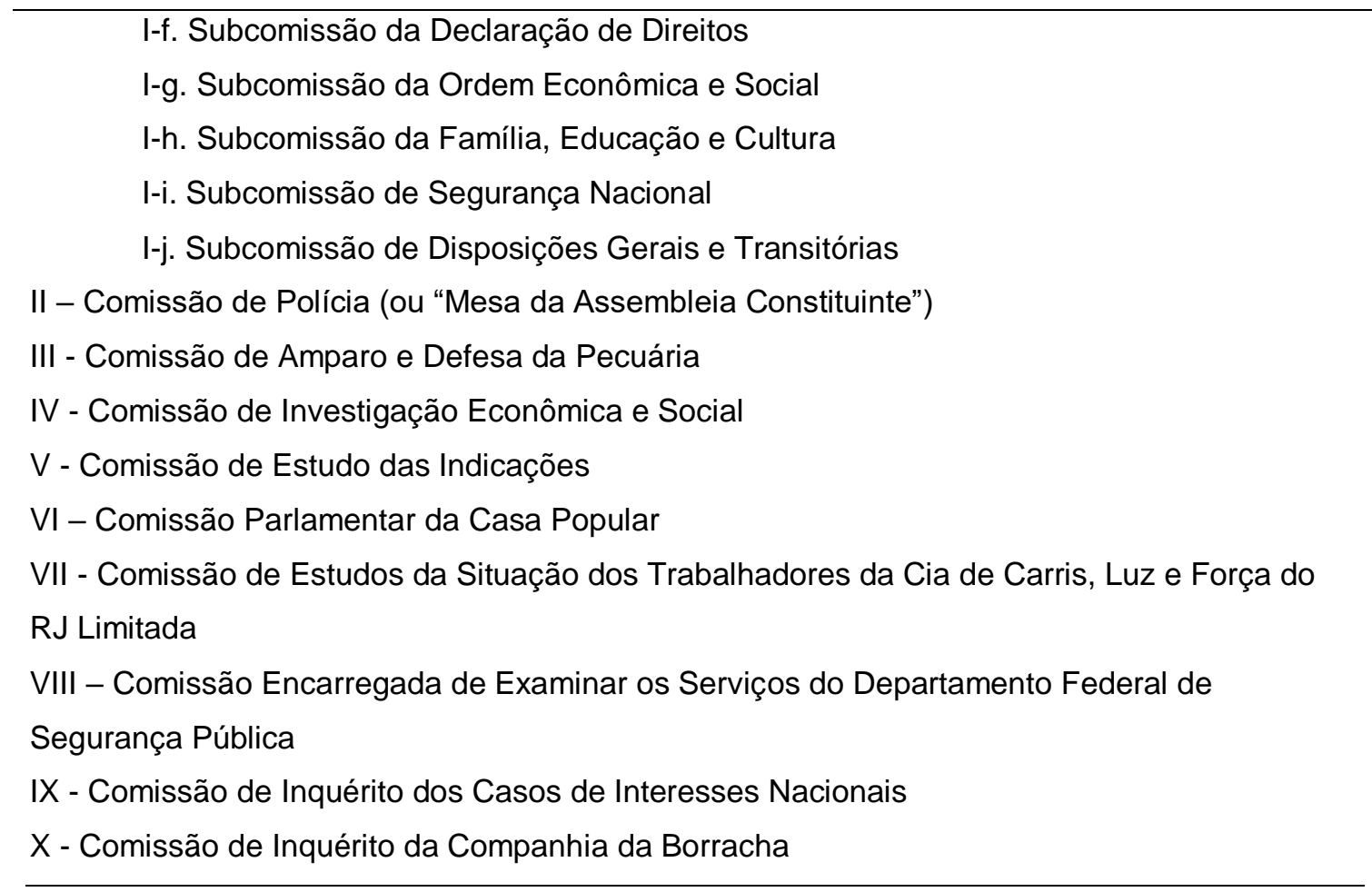

Não havia, em 1946, uma comissão/subcomissão específica para o tema da saúde. Dentre os 56 constituintes das carreiras médicas/sanitárias apenas $15(27 \%)$ integraram alguma comissão, sendo os temas mais variados possíveis (comissão da borracha ou mesmo dos assuntos da 'light', por exemplo). Interessante observar a descrição de Braga (1998) sobre alguns dos constituintes:

\footnotetext{
"João Abdala (PSD) - Atuação constituinte: Parlamentar pouco atuante em plenário, por via das dúvidas optou por não se manifestar sobre assuntos relevantes, nem apresentar emendas ao Projeto de Constituição" (BRAGA, 1998, p. 673).
}

Alguns constituintes provenientes de formação médica/sanitária não exerceram nenhuma atividade atinente à pauta sanitária, se quer propuseram emendas ao anteprojeto sobre o assunto. É o caso de José Maria de Melo (PSD - AL), médico de formação, teve uma atuação pequena na ANC de 1946, fazendo poucos pronunciamentos e sem propor nenhuma emenda, sua participação limitou-se ao tema dos municípios. João Abdala (PSD - SP), de outro lado, apesar de sua formação médica, ainda que tenha atuado na área, 
exerceu diversas atividades atinentes ao mundo empresarial e dos negócios, tendo sido proprietário de vários empreendimentos. Alguns constituintes ainda que não tenham integrado alguma comissão na ANC de 1946, exerceram sua atuação na área por intermédio de emendas. Veja, por exemplo, a atuação de Fernando Teles (UDN - CE):

"Fernando Teles (UDN) - Atuação constituinte: Parlamentar pouco atuante em plenário, concentrou-se na abordagem de questões referentes à organização da saúde pública e ao problema educacional, tendo efetuado pronunciamentos e enviado à Mesa da Assembleia requerimentos e indicações sobre estes assuntos" (ibid, p. 243).

Fernandes Teles (UDN - CE), embora médico, a maioria de suas emendas foram favoráveis ao setor privado na saúde. Dentre elas, destacamse a emenda $n^{\circ}$. 2.525, que requeria a retirada da prerrogativa do Congresso Nacional em legislar sobre a celebração de contratos com entidades privadas brasileiras para o combate de epidemias e endemias. A atuação de Fernando Teles em favor de entidades privadas de saúde foi descrita por Braga (1998) no excerto abaixo:

\footnotetext{
"Apresentou 5 emendas ao Projeto de Constituição, a maior parte delas facilitando a remessa de verbas governamentais para instituições privadas de saúde. Destacam-se as de ํㅡㄴ.525, retirando do Congresso Nacional a prerrogativa de deliberar sobre a celebração de contratos com entidades particulares brasileiras para o combate a epidemias ou endemias; $n$ - 2.974,facultando a abertura de créditos extraordinários para o combate às epidemias; e a de oㅡ 2.978, destinando percentagem da receita líquida da União para o desenvolvimento do ensino, saúde pública e rodovias" (ibid, 1998, p. 243).
}

De outro lado, a ANC 46 teve constituintes provenientes de formação médica/sanitária que atuaram em áreas diversas a sua formação universitária e atuação profissional. Manuel Cavalcanti de Novais (UDN - BA), por exemplo, médico de formação e profissional com atuação em saúde pública na Bahia, legislou em defesa da industrialização e do desenvolvimento econômico: tendo apresentado duas emendas, uma tratando do plano econômico do vale do rio 
São Francisco, outra sobre o funcionalismo público. Eduardo Fróis da Mota (PSD - BA) formou-se médico e, também atuou como pecuarista. Na ANC 46, contudo, não apresentou nenhuma emenda com a pauta sanitária, tendo legislado em prol de obras na sua região e na questão do petróleo. João Batista Luzardo (PSD - RS), médico, pecuarista e advogado, não apresentou nenhuma emenda ao texto, tendo uma passagem rápida e pouco atuante na ANC, licenciando-se do cargo para ocupar a Embaixada do Brasil na Argentina. Seu suplente, o também médico Aristóteles Bayard Lucas de Lima (PSD RS) teve uma participação pequena, encaminhando apenas 1 emenda, sobre os municípios e suas fronteiras.

Luis Régis Pacheco Pereira (PSD - BA) formou-se médico e montou uma clínica para atendimento em sua região, embora em sua atuação constituinte tenha centrado na questão pecuarista. Teófilo Lins Albuquerque (PPS - BA) médico que exerceu a medicina em sua trajetória profissional, na ANC trabalhou em prol da pauta religiosa, do desenvolvimento econômico e do produtor rural.

Pautas sanitárias como 0 amparo à infância $\mathbf{e}$ à maternidade permearam a atuação de alguns parlamentares. João Ferreira Lima (PSD PE), médico, industrial e proprietário de terras (pecuarista e plantador de cana), apresentou no total 3 emendas ao Projeto da Constituição, dentre eles um que destinava $20 \%$ da arrecadação com Imposto de Renda ao amparo à infância e à maternidade. O tema também foi objeto de emenda do constituinte Aluísio Alves (UDN - RN), o mais jovem da ANC de 46. Antonio Maria Resende de Correia (UDN - PI), médico e professor, dentre as suas emendas ao Projeto da Constituição, também propôs a aplicação de verbas para os serviços de assistência à infância e à maternidade. Na mesma linha, procedeu Alcedo Coutinho (PCB - PE), médico, que veio a ocupar uma vaga na Assembleia.

Tema de grande importância nacional, as endemias foram objeto de emenda do constituinte Jarbas Maranhão (PSD - PE), que apresentou propostas sobre a obrigatoriedade da União na resolução de problemas com as inundações e epidemias no nordeste. 
José Augusto Varela (PSD - RN), médico, professor e proprietário de terras, fez importantes contribuições ao projeto da Constituição. Dentre eles, destacamos a solicitação de criação do Ministério da Saúde, independente das pastas de educação e cultura, o que viria a ocorrer apenas em 1953 no Brasil.

Rafael Cincurá de Andrade (UDN-BA) foi um advogado e proprietário de terras baiano, ainda que pouco atuante em plenário, apresentou 10 emendas ao Projeto da Constituição, entre elas a no. 2.136, que tratou da obrigatoriedade da União, em criar hospitais regionais nos Estados.

Muitos constituintes, ainda que não tenham exercido atuação expressiva na ANC 46, assinaram conjuntamente diversas propostas de colegas, que eram membros de comissões ou integravam as mesmas bancadas. Na tabela a seguir (Comissões da ANC de 1946) é possível identificar os constituintes por comissão.

Tabela 5: Comissões da ANC de 1946

\begin{tabular}{|c|c|c|c|c|}
\hline NOME & & PARTIDO & UF & COMISSÕES \\
\hline Agostinho Monteiro & $\begin{array}{l}\text { Médico, Proprietário } \\
\text { de Terras e } \\
\text { Jornalista }\end{array}$ & UDN & PA & $\begin{array}{l}\text { Comissão de } \\
\text { Investigação } \\
\text { Econômica e Social }\end{array}$ \\
\hline Alcedo Coutinho & Médico & PCB & PE & $\begin{array}{l}\text { Comissão de } \\
\text { Investigação } \\
\text { Econômica e Social }\end{array}$ \\
\hline Alfredo Neves & $\begin{array}{l}\text { Médico, Professor e } \\
\text { Jornalista }\end{array}$ & PSD & RJ & $\begin{array}{l}\text { Comissão de } \\
\text { Investigação } \\
\text { Econômica e Social }\end{array}$ \\
\hline Caires de Brito & Médico e Jornalista & PCB & SP & $\begin{array}{l}\text { Comissão da } \\
\text { Declaração de } \\
\text { Direitos }\end{array}$ \\
\hline Diógenes Magalhães & Médico & PSD & GO & $\begin{array}{l}\text { Comissão Enc. de } \\
\text { Examinar os Serviços } \\
\text { do Dep. Fed. de Seg. } \\
\text { Pública }\end{array}$ \\
\hline Epílogo de Campos & Médico e Fazendeiro & UDN & PA & $\begin{array}{l}\text { Comissão de } \\
\text { Inquérito da } \\
\text { Companhia da } \\
\text { Borracha }\end{array}$ \\
\hline Fernandes Távora & $\begin{array}{l}\text { Médico, Jornalista e } \\
\text { Professor }\end{array}$ & UDN & CE & $\begin{array}{l}\text { Comissão de } \\
\text { Inquérito da } \\
\text { Companhia da } \\
\text { Borracha }\end{array}$ \\
\hline Hamilton Nogueira & Médico e Professor & UDN & DF & $\begin{array}{l}\text { Comissão de Estudos } \\
\text { da Situação dos Trab. } \\
\text { Da Light }\end{array}$ \\
\hline
\end{tabular}




\begin{tabular}{|c|c|c|c|c|}
\hline Janduí Carneira & Médico & PSD & PB & $\begin{array}{l}\text { Comissão de } \\
\text { Inquérito da } \\
\text { Companhia da } \\
\text { Borracha }\end{array}$ \\
\hline João Henrique & $\begin{array}{l}\text { Médico e Proprietário } \\
\text { de Terras }\end{array}$ & PSD & MG & $\begin{array}{l}\text { Comissão de Amparo } \\
\text { e Defesa } \\
\text { Agropecuária }\end{array}$ \\
\hline Juscelino Kubitschek & Médico & PSD & MG & $\begin{array}{l}\text { Comissão } \\
\text { Parlamentar da Casa } \\
\text { Popular }\end{array}$ \\
\hline Moreira da Rocha & Médico & PSD & CE & $\begin{array}{l}\text { Comissão de } \\
\text { Inquérito da } \\
\text { Companhia da } \\
\text { Borracha }\end{array}$ \\
\hline Olinto Fonseca & Médico e Jornalista & PSD & MG & $\begin{array}{l}\text { Comissão de } \\
\text { Inquérito dos Casos } \\
\text { de Interesse Nacional }\end{array}$ \\
\hline Raul Pilla & Médico & PL & RS & $\begin{array}{l}\text { Comissão Poder } \\
\text { Executivo }\end{array}$ \\
\hline Régis Pacheco & Médico & PSD & BA & $\begin{array}{l}\text { Comissão de } \\
\text { Inquérito da } \\
\text { Companhia da } \\
\text { Borracha } \\
\text { Comissão de Amparo } \\
\text { e Defesa } \\
\text { Agropecuária }\end{array}$ \\
\hline
\end{tabular}

O quadro acima apresentou a participação de 15 profissionais da saúde que integraram alguma comissão na ANC de 1946. A maior incidência de representantes foi na 'Comissão de Inquérito da Companhia da Borracha', seguido da 'Comissão de Investigação Econômica e Social'. Não houve, contudo, uma comissão específica para tratar do tema da saúde, cuja pauta emergiu em diferentes contextos, ainda que incipientemente.

\section{A) ARTIGO 5 DA CONSTITUIÇÃO DE 1946}

O amplo art. 5을 da CF 46 versou sobre as competências da União, incorporando as relações internacionais, os tratados de guerra e paz, o estado de sítio, dispôs sobre as forças armadas e as forças estrangeiras, o comércio bélico e a organização das polícias marítima, aérea e de fronteiras; previu também a competência da União em legislar sobre o direito civil, comercial, penal, processual, eleitoral, aeronáutico e do trabalho, bem como, em várias 
áreas desde financeiras até a proteção da saúde e seguridade, como observado no inciso XV:

\author{
Art. 5․ Compete à União: \\ (...) \\ $\mathrm{XV}$ - legislar sobre: \\ a) direito civil, comercial, penal, processual, eleitoral, aeronáutico e \\ do trabalho; \\ b) normas gerais de direito financeiro; de seguro e previdência \\ social; de defesa e proteção da saúde; e de regime penitenciário; \\ $(\ldots)$
}

Neste a parte, houve apenas uma intervenção de Gustavo de Capanema, que sugeria pequena alteração da redação inicial, suprimindo-se o termo "e os serviços neles reservados à União", permanecendo simplesmente "legislar sobre", com a aprovação da Emenda Supressiva.

Tabela 6: Emendas ao Art. 5 da Constituição de 1946

\begin{tabular}{|c|c|c|}
\hline Emenda & Autor & Teor \\
\hline $\begin{array}{l}\mathrm{s} / \mathrm{n}^{35} \text { ao Art. } \\
164\end{array}$ & $\begin{array}{l}\text { Gustavo } \\
\text { Capanema }\end{array}$ & $\begin{array}{l}\text { "No art. } 164 \text { é desnecessária a frase "em todo o território nacional". O } \\
\text { que parece indispensável é dizer que a obrigação de proteger a } \\
\text { maternidade e a infância cabe aos poderes públicos. Deve, } \\
\text { mesmo, ficar declarado que esse dever incumbe à União, aos } \\
\text { Estados, ao Distrito Federal e aos Municípios". (Diário da Assembleia, } \\
17 / 09 / 46, \text { p. 4994). }\end{array}$ \\
\hline $\begin{array}{l}\text { s/n aos Arts. } \\
163 \text { e } 164\end{array}$ & $\begin{array}{l}\text { Gustavo } \\
\text { Capanema }\end{array}$ & $\begin{array}{l}\text { "Diz o art. } 163 \text { que a família "terá direito à proteção especial do } \\
\text { Estado". E o art. } 164 \text { acrescenta: "A lei instituirá o amparo das } \\
\text { famílias de prole numerosa". As duas declarações versam sobre o } \\
\text { mesmo assunto, e poderiam, reunir-se, ou contrair-se, num só artigo". } \\
\text { (Diário da Assembleia, } 17 / 09 / 46, \text { p. } 4994 \text { e 4995). }\end{array}$ \\
\hline
\end{tabular}

Fonte: Dados compilados a partir das emendas publicadas no Diário da Assembleia de 1946.

Observa-se, segundo a análise de Pontes de Miranda (1953) que o tema é tratado enquanto 'normas gerais', ou seja, as “(...) que a União considera essenciais plano ou programa geral de defesa e proteção da saúde, ainda que se especialize a respeito de endemias ou epidemias, ou a respeito da infância, da maternidade, ou da velhice". Não se trata de um efeito limitador - como

\footnotetext{
${ }^{35}$ As contribuições de Capanema foram enviadas após o período estabelecido, contudo, o então presidente da ANC, determinou a publicação de suas considerações: "Emendas apresentadas após a extinção do prazo e mandadas publicar por ordem do Sr. Presidente", conforme publicado no Dário da Assembleia de 17 de setembro de 1946.

${ }^{36}$ Grifos Nossos.
} 
possa parecer - e sim que "(...) o legislador recomenda a legislação de defesa e de proteção da saúde". Se uma legislação estadual, por exemplo, contradizer a norma geral: se for anterior a essa, será revogada; se posterior será inconstitucional. Nesse artigo, o legislador deixa livre a atuação dos Estados no setor, respeitando-se o preceito supracitado. (MIRANDA, P. 1953, vol. I, p. 371).

\title{
6. REDAÇÃO FINAL
}

A versão antecedente à conclusiva contou com várias emendas, sobretudo, alusivas à questão vernacular. Não obstante, desde os últimos códigos, o Congresso Nacional já recorrera, no tocante extra-parlamentar, aos filólogos e etimólogos, a fim de exaurir "incorreções vernáculas, de despautérios, de dissonâncias, de cacofonias, de aliterações ${ }^{37}$, elisões ${ }^{38}$, em suma, vícios de linguagem que se encontram no texto". Nesta fase, portanto, passou-se a enumerar os erros contidos no texto, quanto à sua forma, tendo-o já sido revisto o seu conteúdo. (DUARTE, J. Constituição Brasileira 1946, p. 138).

Segundo o deputado constituinte Aliomar Baleeiro, membro da Grande Comissão:

\begin{abstract}
"No seio deste, recebeu milhares de emendas, que sofreram a triagem dos relatores na Comissão. Esta refundiu o projeto com as emendas por ela aprovadas e - novo texto desceu a plenário, permitindo-se o "destaque" das emendas refutadas para discussão e votação de cada um deles assim admitidas, depois de aprovado, globalmente, aquele projeto da Comissão, "salvo emendas". A redação final de Prado Kelly ainda passou pela revisão do filólogo José de Sá Nunes". (BALEEIRO, A. 2012. p. 10).
\end{abstract}

Após a conclusão dos trabalhos de redação, pôs-se em votação e fora promulgada em 18 de setembro de 1946, a Constituição dos Estados Unidos

\footnotetext{
${ }^{37}$ Figura de linguagem que consiste na repetição de sons de consoantes iguais ou semelhantes.

${ }^{38}$ Supressão de frase ou palavra em uma frase.
} 
do Brasil e o Ato Constitucional das Disposições Provisórias. (DUARTE, J. Constituição Brasileira 1946, p. 138).

\section{COMPOSIÇÃO}

l) Profissões - área da saúde:

Analisaremos a composição da Assembleia Nacional Constituinte de 1946, a partir dos indicadores partidários, regionais e profissionais dos seus membros. A tabela a seguir apresenta os constituintes de acordo com a profissão declarada, dentre os profissionais da saúde, além do partido político cujo constituinte fora eleito e o Estado que representava.

Tabela 7: Deputados e Senadores Constituintes

\begin{tabular}{llccl}
\hline & \multicolumn{1}{c}{ NOME } & PARTIDO & ESTADO & PROFISSÃO \\
\hline 1 & Ademar Rocha & UDN & PI & Médico \\
2 & Afonso Matos & PSD & MA & Médico \\
3 & Agostinho Monteiro & UDN & PA & Médico \\
4 & Agrícola de Barros & UDN & MT & Médico \\
5 & Alarico Pacheco & UDN & MA & Médico \\
6 & Alcedo Coutinho & PCB & PE & Médico \\
7 & Alfredo Neves & PSD & RJ & Médico \\
8 & Antônio Correia & UDN & PI & Médico \\
9 & Aramis Ataíde & PSD & PR & Médico \\
10 & Augusto Varela & PSD & RN & Médico \\
11 & Bastos Tavares & PSD & RJ & Médico \\
12 & Batista Luzardo & PSD & RS & Médico \\
13 & Bayard de Lima & PSD & RS & Médico \\
14 & Benjamin Farah & PTB & DF & Médico \\
15 & Carlos Nogueira & PSD & PA & Dentista \\
16 & Caires de Brito & PCB & SP & Médico \\
17 & Diógenes Magalhães & PSD & GO & Médico \\
18 & Durval Cruz & PR & SE & Médico \\
19 & Epílogo de Campos & UDN & PA & Médico \\
20 & Erasto Gaertner & UDN & PR & Médico \\
21 & Felipe Balbi & PR & MG & Médico \\
22 & Fernandes Távora & UDN & CE & Médico \\
23 & Fernandes Teles & UDN & CE & Médico \\
24 & Ferreira Lima & PSD & PE & Médico
\end{tabular}




\begin{tabular}{llccc}
25 & Fontes Romero & PSD & DF & Médico \\
26 & Fróis da Mota & PSD & BA & Médico \\
27 & Hamilton Nogueira & UDN & DF & Médico \\
28 & Janduí Carneira & PSD & PB & Médico \\
29 & João Abdala & PSD & SP & Médico \\
30 & João d'Abreu & PSD & GO & Dentista \\
31 & João Henrique & PSD & MG & Médico \\
32 & Joaquim Libânio & PSD & MG & Médico \\
33 & José Candido & UDN & PI & Médico \\
34 & José Maria & PSD & AL & Médico \\
35 & Juscelino Kubitschek & PSD & MG & Médico \\
36 & Leão Sampaio & UDN & CE & Médico \\
37 & Levindo Coelho & PSD & MG & Médico \\
38 & Lino Machado & PR & MA & Médico \\
39 & Lopes Ferraz & PSD & SP & Médico \\
40 & Manuel Novaes & UDN & BA & Médico \\
41 & Mércio Teixeira & PSD & RS & Médico \\
42 & Miguel Couto & PSD & RJ & Médico \\
43 & Moreira da Rocha & PSD & CE & Médico \\
44 & Nicolau Vergueiro & PSD & RS & Médico \\
45 & Novelli Júnior & PSD & SP & Médico \\
46 & Odilon Soares & PSD & MA & Médico \\
47 & Olinto Fonseca & PSD & MG & Médico \\
48 & Pedro Ludovido & PSD & GO & Médico \\
49 & Raul Pilla & PL & RS & Médico \\
50 & Régis Pacheco & PSD & BA & Médico \\
51 & Romão Júnior & UDN & RJ & Médico \\
52 & Rui Santos & UDN & BA & Médico \\
53 & Sigefredo Pacheco & PSD & PI & Médico \\
54 & Teódulo Albuquerque & PSP & BA & Médico \\
55 & Silvio de Campos & PSD & SP & Médico \\
56 & Vaspasiano Martins & UDN & MT & Médico \\
\hline & & & & \\
\end{tabular}

Observa-se a majoritária incidência da classe médica, que representou 96,42\% (54) dos constituintes da área da saúde, contra 3,57\% (02) dentistas. 
Figura 1: Distribuição das profissões na área da saúde dos parlamentares que participaram da constituinte de 1946 - Deputados.

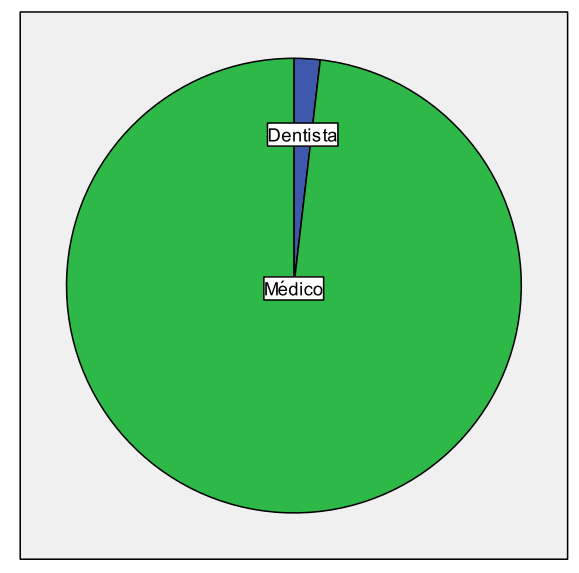

Tabela 8: Distribuição das profissões na área da saúde dos parlamentares que participaram da constituinte de 1946 - Deputados.

\begin{tabular}{ccc}
\hline \multicolumn{3}{c}{ Parlamentares com profissão na área da saúde } \\
\hline Profissão & $\begin{array}{c}\text { Frequência } \\
\text { Absoluta }\end{array}$ & Porcentagem \\
\hline Médica & 54 & 96,42 \\
Dentista & 2 & 3,57 \\
Total & 56 & 100,0 \\
\hline
\end{tabular}

II) Partidos Políticos e Região (UF):

Nas figuras seguintes é possível identificar a predominância do PSD e da UDN, entre os partidos com maior número de constituintes. Quanto ao perfil regional, temos destaque para os Estados de Minas Gerais, Rio Grande do Sul e Bahia, seguidos de São Paulo, Rio de Janeiro, Piauí, Maranhão e Ceará. 
Figura 2: Distribuição dos parlamentares por partido político.

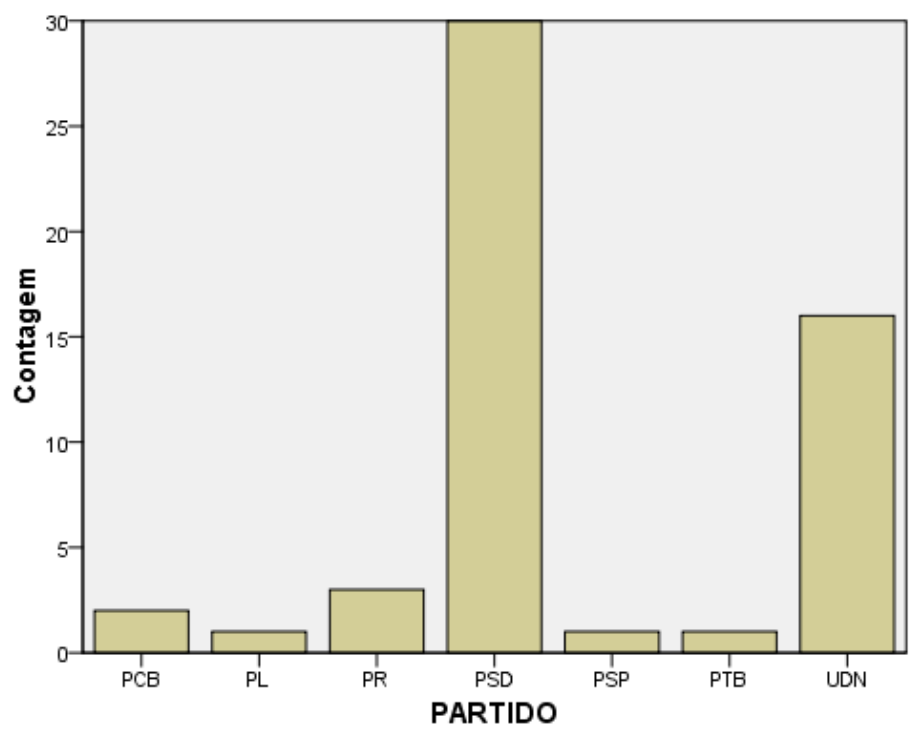

Figura 3: Distribuição dos parlamentares por Estado.

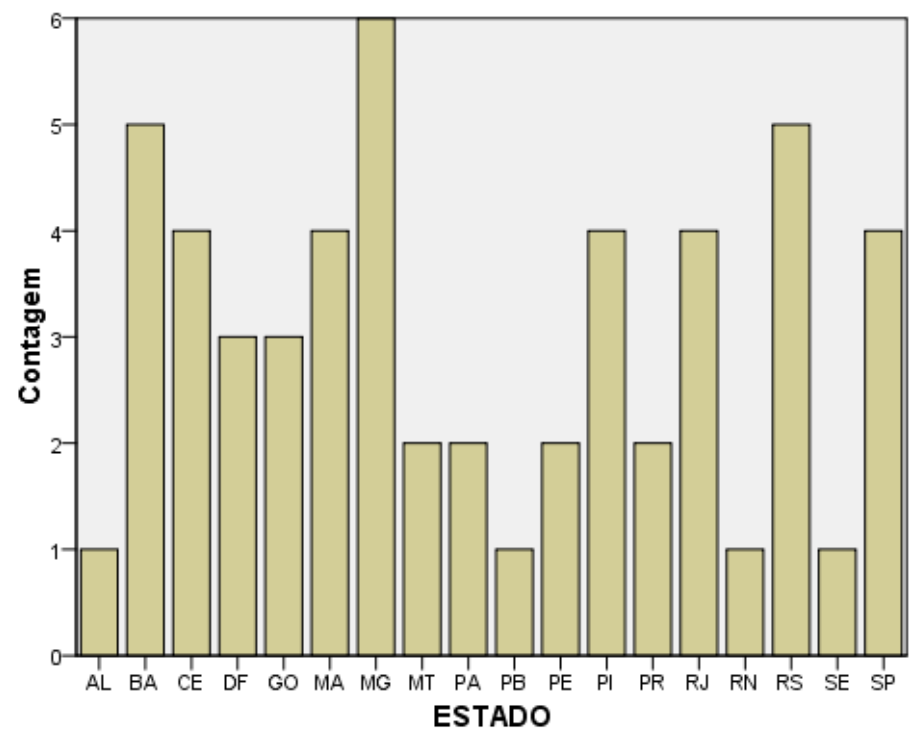


Figura 4: Dispersão dos parlamentares profissionais de saúde em relação ao partido político e ao estado - constituinte de 1946 - Deputados.

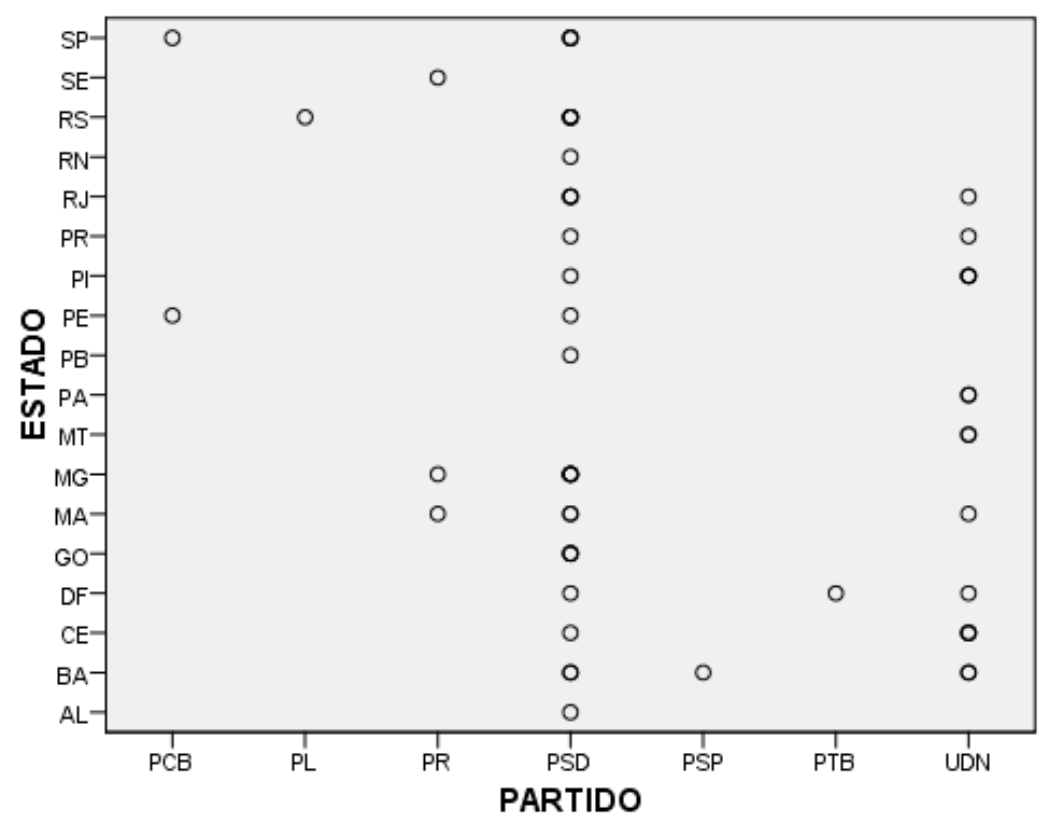




\title{
B. A REFORMA SANITÁRIA BRASILEIRA
}

\begin{abstract}
"Está em curso uma reforma democrática não anunciada ou alardeada na área da saúde. A Reforma Sanitária brasileira nasceu na luta contra a ditadura, com o tema Saúde e Democracia, e estruturou-se nas universidades, no movimento sindical, em experiências regionais de organização de serviços. Esse movimento social consolidou-se na $8^{\text {a }}$ Conferência Nacional de Saúde, em 1986, na qual, pela primeira vez, mais de cinco mil representantes de todos os seguimentos da sociedade civil discutiram um novo modelo de saúde para o Brasil. O resultado foi garantir na Constituição, por meio de emenda popular, que a saúde é um direito do cidadão e um dever do Estado." (AROUCA, S. 1998).
\end{abstract}

O movimento da reforma sanitária brasileira está largamente associado a dois acontecimentos notórios no campo da saúde no país: a $8^{\text {a }}$ Conferência Nacional de Saúde e a criação da Comissão Nacional da Reforma Sanitária, a CNRS, em meados da década de 80. A CNRS, criada a partir da $8^{a}$ Conferência, contou com grande representatividade, dada pela ampla participação naquele evento. À Conferência, em março de 1986, compareceram cerca de cinco mil pessoas, entre delegados e representantes de todo o país (CNS, 1986, DOC. II, p. 07).

O termo, originário da reforma sanitária italiana, permaneceu esquecido até ser recuperado nos debates de preparação para a $8^{\underline{a}} \mathrm{CNS}$, posteriormente sendo amplamente utilizado a se referir ao "conjunto de ideias que se tinha em relação às mudanças e às transformações necessárias na área da saúde". Às mudanças acresciam todo o sistema de saúde, introduzindo uma nova ideia, cujo resultado se traduzia em melhores condições de vida a toda população. "Era um conjunto de pessoas com ideias comuns para o campo da saúde". (FIOCRUZ, 2019).

Apesar desses dois significativos momentos, a origem do movimento, contudo, é anterior, provém da segunda metade da década dos anos 1970 e coincide com a criação de duas importantes instituições na área da saúde no país: a criação do CEBES - Centro Brasileiro de Estudos da Saúde (em 1976) e, posteriormente, da ABRASCO - Associação Brasileira de Saúde Coletiva 
(em 1979). Podemos dizer, ainda, que os primeiros ensejos de uma reforma sanitária nasceram do desenvolvimento da medicina preventiva, desde a década de 50, acompanhada da profunda insatisfação com os regimes autoritários no Brasil, onde se acreditava que apenas a derrocada destes representaria a possibilidade de criação de um sistema de saúde eficiente e democrático. (PAIVA, C; TEIXEIRA, L. 2014, p. 21).

Segundo Paim (2007), na década de 70, enquanto as contradições eram aprofundadas no âmbito da saúde, houve um 'renascimento' dos movimentos sociais, composto pela classe trabalhadora, pelos estudantes e representantes dos setores populares, intelectuais e profissionais da classe média, traduzindose na possibilidade de articulação desses setores, enquanto forças sociais contrárias às políticas de saúde 'autoritárias e privatizantes' (PAIM, J. 2007, p. 75).

A criação do CEBES, durante a 32a Reunião Anual da Sociedade Brasileira para o Progresso da Ciência (SBPC), mobilizou homens e mulheres para pensar e mudar a saúde, constituindo um movimento pela democratização da saúde, "a partir da socialização da produção acadêmica crítica da emergente Saúde Coletiva brasileira". O CEBES organizou reuniões em parceria com a SBPC, publicou livros entre outras diversas atividades, constituindo um conjunto de elementos que, posteriormente, se traduziria na ideia de uma 'reforma sanitária'. Paim (2007) cita Escorel (1995) para traduzir este momento - onde se constituiu "uma pedra fundamental, embora não a única, do movimento sanitário como movimento social organizado" (ibid. 2007, p. 76).

Paim (2007) destaca na atuação do CEBES - dentre tantas mobilizações políticas - a apresentação do documento 'A questão democrática da Saúde' (CEBES, 1980), no I Simpósio de Política Nacional de Saúde, da Comissão de Saúde (CÂMARA DOS DEPUTADOS, 1980). Neste documento foi proposto, pela primeira vez, a criação do SUS - representando um marco na reforma sanitária brasileira: "ou seja, não se trata mais de uma ideia da necessidade de uma reforma, mas de um conjunto de preposições" (ibid, p. 78). 
O movimento seguinte foi a criação da ABRASCO, que segundo Paim (2007) se traduzia mais em um 'movimento' do que, propriamente, uma entidade (PAIM, J. 2007, p. 78). Essas instituições são consideradas peçaschave na construção da identidade desta área do conhecimento que ficou conhecida como 'Saúde Coletiva':

"No lugar de uma perspectiva autoritária, a ABRASCO e o CEBES defenderam participação social; no lugar de políticas de controle de doenças, notadamente transmissíveis, a promoção da saúde e melhoria da qualidade geral de vida; no lugar de um setor dividido entre saúde pública e medicina previdenciária, um sistema unificado e universal" (PAIVA, C. TEIXEIRA, L. 2014, p. 22).

\title{
1. COMISSÃO NACIONAL DA REFORMA SANITÁRIA - CNRS
}

A Comissão Nacional da Reforma Sanitária (CNRS) foi constituída por uma comissão interministerial (Ministros da Saúde, Educação e Previdência e Assistência Social) durante o governo de Jose Sarney, que participou da $8^{a}$ CNS e manifestou-se em um discurso em defesa da participação social, da qualidade de vida da população e da assistência médica. $O$ presidente destacou, ainda, a importância da $8^{\text {a }}$ Conferência nos trabalhos da futura ANC: "Faço votos de que esta conferência (...) represente a pré-Constituinte da saúde no Brasil" (CNRS, Doc. I, p. 9).

\section{2. $8^{a}$ CONFERÊNCIA NACIONAL DE SAÚDE - CNS}

\begin{abstract}
"Trata-se de marco político importante: é quando a saúde é trazida para a arena de um amplo debate público. Para além do evento específico, ela envolveu uma série de debates prévios e de conferências posteriores por temáticas específicas após sua realização, em março de 1986. Representou ela, ainda, a grande arrancada para o embate público que haveria quando da eleição e instalação da Assembleia Nacional Constituinte". (COHN, A. 1989).
\end{abstract}

A 8 a Conferência Nacional de Saúde, realizada entre 17 e 21 de março de 1986, contou com ampla participação de entidades da sociedade civil. Foram realizadas pré-conferências preparatórias estaduais e municipais, 
decorrendo na escolha de quase 1.000 delegados. Após um grande processo de trabalho, foi apresentado o documento para aprovação em plenária, contando com relato consolidado dos 135 grupos de trabalho (38 de delegados e 97 de participantes), versando sobre os eixos: I) Saúde como Direito; II)Reformulação do Sistema Nacional de Saúde; e III) Financiamento do Setor de Saúde (CNRS, Doc. I, p. 11).

Segundo o relatório final, a realização da $8^{a}$ CNS foi permeada pela participação democrática:

\footnotetext{
"O processo altamente participativo, democrático e representativo que permeou todo o debate na 8. a CNS permitiu um alto grau de consenso, caracterizando uma unidade quanto ao encaminhamento das grandes questões, apesar da diversidade de propostas quanto às formas de implantação implementadas" (ibid, $p$. $11)$.
}

O relatório final destacou ainda quatro outros pontos concernentes aos debates e cuja importância transcende os eixos temáticos supracitados: I) a mudança necessária vai além da reforma administrativa e financeira; II) a questão da estatização do serviço de saúde - e se imediata ou progressiva; III) a separação ou não da saúde e seguridade social; e IV) princípios que deveriam nortear o financiamento da saúde (ibid, p. 12).

A 'Saúde como Direito', um dos quatro temas da $8^{\text {a }} \mathrm{CNS}$, foi abordada sobre treze aspectos. O primeiro, em sua relação à desigualdade de vida e como produto de múltiplos aspectos (alimentação, habitação, educação, renda, meio ambiente, trabalho, transporte, emprego, lazer, liberdade, acesso e posse da terra e serviços de saúde). O segundo definiu 'saúde' não apenas como um conceito abstrato, mas algo pertinente a um contexto histórico de determinada sociedade, em certo momento de desenvolvimento e que deveria ser construída na luta diária pela população. $\mathrm{O}$ terceiro aspecto entende o 'direito à saúde' como algo a ser garantido pelo Estado, ao levar condições dignas de vida a toda a população, com acesso igualitário e universal aos seus serviços, em todos os níveis e em todo território nacional. O quarto discorreu no tocante ao 'direito à saúde' ser de atuação estatal; concluiu-se que o tema não deveria 
estar apenas no texto constitucional, mas traduzir-se em uma prioridade efetiva do Governo, através de suas políticas públicas. (ibid, p. 13). O quinto item da $8^{\text {a }}$ CNS sobre o 'direito à saúde' apresentou esse conceito sobre um espectro mais amplo, concluindo-o como uma conquista social indissociável de outros elementos determinantes para o seu pleno exercício: I) trabalho; II) alimentação; III) moradia; (V) educação; V) meio ambiente; VI) transporte; VII) repouso, lazer e segurança; VIII) controle social; IX) liberdade; e X) acesso universal e igualitário (ibid., p. 13).

Do sexto ao décimo item foram abordados aspectos concernentes à sociedade brasileira e às vicissitudes do sistema político em detrimento ao pleno exercício do 'direito à saúde'. O sexto item esclareceu a natureza estrutural dos problemas ligados à saúde, enquanto o sétimo aspecto elencado os associaram a uma sociedade extremamente hierarquizada e estratificada, com elevada concentração de renda, em que coexistem condições precárias de trabalho e avançada tecnologia capitalista. O 'Documento I - Relatório da CNRS' atribuiu, em seu oitavo item, parte disso aos governos autoritários e ao regime militar, que intensificaram a desigualdade social. Essas vicissitudes, segundo o item nove, favoreceram - no campo da saúde - a prevalência dos interesses dos empresários da área médico-hospitalar no sistema. Esses fatores foram gerados, sobretudo - segundo o décimo item - por fatores como: não prioridade do governo com a saúde; política de mercantilização da saúde; debilidade da organização da sociedade civil no controle social da saúde; modelo social excludente; falta de transparência nos recursos; formação inadequada de recursos humanos; controle multinacional de medicamentos e equipamentos; aplicação de recursos públicos na rede privada; interferências clientelistas nas contratações; e, por fim, centralização em nível federal (ibid., p. 14).

A oitava conferência também atribuiu ao Estado papel fundamental na efetivação do 'direito à saúde'. Nos itens seguintes - onze e doze - foi retratada a necessária atuação do Estado frente a garantir melhores condições de vida, através de políticas sociais e econômicas, o financiamento da saúde, a descentralização dos serviços de saúde e a fiscalização de padrões de 
qualidade. A efetivação desse direito, contudo, requer a imprescindível realização de uma ANC, o resguardo do direito a uma vida digna através da CF, o rompimento com a dívida externa, a implementação da reforma agrária, assegurar o controle social, a realização da reforma fiscal e tributária e a previsão orçamentária de recursos à saúde. Por fim, o item treze do 'direito à saúde' do Relatório Final, conhecido como 'Documento III' reforçou que a 'saúde' deveria ser entendida como interesse coletivo, dever do Estado e prioridade nas políticas sociais, com acesso igualitário e em todos os níveis em âmbito nacional, através de serviços públicos e natureza essencial:

\footnotetext{
"É necessário que se intensifique o movimento de mobilização popular para garantir que a Constituinte inclua a saúde entre as questões que merecerão atenção prioritária. Com este objetivo, a partir da 8. ${ }^{a}$ Conferência Nacional de Saúde, deverá ser deflagrada uma campanha nacional em defesa do direito universal à saúde, contra a mercantilização da medicina e pela melhoria dos serviços públicos" (ibid., p. 15).
}

O segundo grande tema da 8" CNS foi a 'Reformulação do Sistema Nacional de Saúde'. O documento apresentou vinte e sete tópicos para a reforma, versando desde a criação do Sistema Único de Saúde - em sua maior parte - até a propaganda de medicamentos, e também integrou o 'Documento l' da CNRS. A premissa do tema - integrando o item 1 do relatório apresentou a criação de um 'Sistema Único de Saúde', como resultado da reestruturação do Sistema Nacional de Saúde, representando um "novo arcabouço institucional" e a separação definitiva entre 'saúde' e 'previdência', através de uma ampla Reforma Sanitária. O item 2 estabeleceu que a organização desse sistema deveria ser coordenada, em nível federal, pelo Ministério da Saúde e reproduzida nos Estados e municípios (ibid., p. 17).

Dentre os princípios do SUS, previstos no item 3, estabeleceram-se três frentes: a) organização dos serviços; b) condições de acesso e qualidade; e c) política de recursos humanos. Quanto à organização (a) destacou-se o fortalecimento dos municípios, a descentralização dos serviços, a regionalização e hierarquização. As condições de acesso (b) previram a universalização à cobertura populacional - priorizando as áreas mais carentes 
e desassistidas, equidade, atendimento oportuno conforme as necessidades, respeito à dignidade do usuário e inovou ao garantir o direito de acompanhamento ao paciente - principalmente às crianças, e o direito à assistência psicológica. Sobre a política de recursos humanos (c) previu uma remuneração condigna e a isonomia salarial, a capacitação e reciclagem, o ingresso por concurso público, a estabilidade no emprego, a composição multiprofissional das equipes, o cumprimento da carga horária e incentivo à dedicação exclusiva, o direito à greve, a formação dos profissionais, a inclusão das práticas alternativas no currículo do ensino de saúde e a incorporação dos 'agentes populares de saúde' como atividade remunerada, dedicando-se principalmente à educação para a saúde e aos cuidados primários (ibid., p. 18).

O tocante ao item 4 , que tratou da prestação estatal dos serviços de saúde e dos serviços privados, foi objeto de grande debate, mais adiante, na Comissão da Ordem Social, na ocasião da ANC 87-88. O texto da CNRS colocou como objetivo principal da Reforma Sanitária “(...) o Sistema Único de Saúde, com expansão e fortalecimento do setor estatal em níveis federal, estadual e municipal, tendo como meta uma progressiva estatização do setor". A saúde privada foi posta como serviço subordinado e fiscalizado pelo Estado, coibidos os lucros abusivos e previsto a sua expropriação na inobservância das normas estabelecidas pelo Poder Público. Esse debate figurou como ponto divergente $\mathrm{e}$ alvo de várias emendas na FASE $\mathrm{B}$ dos trabalhos da Subcomissão de Saúde, Seguridade e Meio Ambiente da ANC de 87-88 (ibid., p. 18).

O item 5 reforçou o caráter descentralizado proposto pela RSB, cujo perfil federativo da República brasileira estabeleceu o poder político, administrativo e financeiro dos Estados e Municípios. No item seguinte, traçaram-se as principais atribuições, em nível federal, do SUS: formulação e condução da Política Nacional de Saúde, regulação da relação público-privado na saúde, acompanhamento da cobertura assistencial, condução de programas emergenciais não contemplados pelos outros entes federativos, além da "definição das políticas setoriais de tecnologia, saneamento, recursos humanos, insumos básicos, financiamento e informações; determinação de 
padrões de qualidade homogêneos para os setores público e privado" (ibid., p. 18).

Ainda em nível federal, o item 7 previu a manutenção em seu poder dos serviços de referência nacional, bem como, os considerados estratégicos ao sistema de saúde, como por exemplo, a produção de imunobiológicos, medicamentos e equipamentos, além dos órgãos de pesquisa. Assim, os demais serviços - que tratou o item 8 - aqueles que possuíam caráter local e caracterizavam-se pelo atendimento à população deveriam ser repassados para Estado e municípios, juntamente com seus recursos humanos, materiais e financeiros (ibid., p. 19).

O item 9 tratou das atribuições dos Estados. A 8 a CNS previu a responsabilidade dos Estados na elaboração de seus planos diretores para a área da saúde e a criação de subsistemas estaduais de saúde, seguindo as determinações federais e considerando as peculiaridades regionais e municipais. Ainda, indica a responsabilidade estadual, prioritariamente, na prestação de serviços de atenção secundária e terciária, àquelas consideradas complexas e insuficientes pelos municípios. No bojo das questões municipais, o relatório indicou as grandes cidades como responsáveis pela gestão integral do Sistema Municipal de Saúde, sendo amparadas em sua impossibilidade pelos governos Estaduais e Federal, que ficariam ainda responsáveis pela assistência aos municípios menores, conforme tratou o item 11 (ibid., p. 19).

A 8 ${ }^{a}$ CNS indicou, também, no item 12, que os hospitais universitários e os das Forças Armadas deveriam estar totalmente integrados ao Sistema Único de Saúde. Sobre a iniciativa privada, abordada nos itens 13 e 14, estabeleceu que o 'relacionamento público-privado' deveria ocorrer através do controle efetivo do público sobre o privado. Indicou às parcerias já existentes junto ao INAMPS a celebração de um novo contrato, baseado no Direito Público, no qual o serviço privado passaria a ser um concessionário do Estado. Esses contratos deveriam se pautar por critérios de "adequação ao perfil epidemiológico da população a ser coberta e de parâmetros de desempenho e qualidade". Mais do que isso, o relatório previu que, a partir de 30 de março daquele ano, tornar-se-iam vedadas as novas concessões. Reforçou-se a 
possibilidade de expropriação dos serviços privados de saúde em caso de fraude ou conduta dolosa - adotando-se sistemas de proteção da sociedade. Previu, também, a revisão dos incentivos estatais à medicina de grupo. (ibid., p. 20).

No item 15, aos locais onde houvesse escassez de oferta dos serviços públicos de saúde, em vez de medicina de grupo, o relatório ocupou-se de solucionar essa questão com duas medidas: redirecionamento de recursos públicos e corte de financiamentos à rede privada. A fim de solucionar deficiências do serviço público, o relatório sugeriu - em seu item 16 - o aprimoramento dos processos gerenciais, almejando maior eficiência e resolubilidade indo ao encontro dos anseios da população, posto que "a maior participação do setor público como prestador de serviços é viável, justa e socialmente desejável" (ibid., p. 20).

A CNRS apresentou enquanto necessária a intervenção para estatização de setores estratégicos da saúde no país. Propôs-se, no item 17, o fortalecimento dos laboratórios e indústrias estatais direcionados à saúde, a estatização de serviços considerados estratégicos - como a produção de imunobiológicos, produção e comercialização de sangue e hemoderivados, além da estatização da indústria farmacêutica. Nos itens de 19 a 22, essa discussão foi posta com a indicação da formulação de uma política para o desenvolvimento científico e tecnológico da produção de insumos inerentes aos serviços de saúde. Sugeriu-se, ainda, a preservação da soberania nacional, com a reavaliação do relacionamento do Brasil com as indústrias internacionais, além da intensificação da produção brasileira na área da saúde (ibid, p. 20).

Retornando ao item 18, outro ponto debatido na $8^{\text {a }}$ CNS foi a publicidade de medicamentos. Decidiu-se pelo indicativo de proibição de propagandas comerciais de medicamentos e outros produtos nocivos à saúde. (ibid., p. 20).

Nos itens seguintes - 23 a 26 - foi abordada uma questão recorrente na 8 a CNS, o Controle Social. Sugeriu-se inclusive ao texto constitucional, a criação de um Sistema Nacional de Informação. Visando à ampliação da participação, além de transparência, propôs-se a criação do Conselho Nacional 
de Saúde - e similares nos níveis locais. Por fim, o item 27 apresentou os trabalhos da 8a CNS como instrumentos para a realização da ANC, sugerindo, inclusive, a criação de um comitê executivo da Reforma Sanitária (ibid., p. 21).

A $8^{a}$ CNS teve como terceiro grande tema o 'financiamento da saúde', no qual foram levantadas 9 propostas. Logo no primeiro item, o relatório requereu a criação de um 'orçamento social', que, dentre outras áreas, contemplaria a saúde. Os recursos destinados à saúde constituiriam o "Fundo Único Federal de Saúde", formando-se, ainda, fundos específicos em nível estadual e municipal. No item 2, o relatório indicou a gestão conjunta desse fundo entre gestores públicos e os conselhos populares. E avançou, no item 3, ao estipular a necessária destinação percentual de recursos à saúde, algo há ainda ser debatido na ANC (ibid., p. 23).

Mais uma vez, reforçou-se o papel do Estado na Reforma Sanitária. O item 4 expressou diretamente a obrigatoriedade Estatal de financiamento do sistema de saúde. A questão da previdência foi atrelada ao trabalhador, no item 5, prevendo a exclusividade da destinação orçamentária. $O$ item 6 previu a substituição gradual dos recursos da previdência no financiamento da saúde por recursos próprios. Nos itens seguintes - 7 e 8 - foram indicadas as seguintes medidas: redução de cobranças no salário do trabalhador e supressão de descontos nos proventos dos aposentados, a fim de que gozem de uma boa renda e melhor qualidade de vida. Pelo relatório, a distribuição de recursos públicos na saúde deveria primar não apenas pela questão populacional de determinada região e a arrecadação fiscal dali, mas considerar, também, as condições de vida no local (CNRS, Doc. I, p. 23).

Atrelado à descentralização, o item 9 abordou a reforma tributária prevendo uma revisão do financiamento da saúde, que estabeleceria fontes estáveis de receita, aumento de recursos aos Estados e municípios, eliminação de isenções de pessoas jurídicas de gastos com saúde e consideraria o gasto familiar, deduzindo-o nesse caso do valor do Imposto de Renda, a taxação de empresas poluentes, e, por fim, tributando as empresas em razão de acidentes de trabalho (ibid., p. 23). 
O amplo debate da $8^{\text {a }}$ CNS foi fundamental no subsídio aos debates sanitários da ANC de 1987-88, tendo sua pauta apresentada e debatida pelos constituintes, sobretudo, por expoentes isolados que levantaram proposições importantes do debate produzido na conferência e avançando significativamente em assuntos específicos como a pauta dos medicamentos, participação da iniciativa privada na saúde, vacinação, epidemias etc. 


\section{A ANC DE $1987-88$}

Em 07 de agosto de 1984, o movimento chamado "Frente Liberal", composto pelo PMDB e pelo grupo situacionista dissidente, lançou um documento-base para a transição democrática, intitulado: "O Compromisso da Aliança Democrática". A sua elaboração contou com a participação de Tancredo Neves, José Sarney, Ulysses Guimarães e Marco Maciel - que destinava os finais de semana em Brasília para recolher as sugestões ao texto - entre outros colaboradores. No âmbito da saúde, dentre os compromissos fundamentais do documento, associado às carências básicas da população, estavam "o direcionamento de recursos e estímulos para o aumento substancial da oferta de bens e serviços indispensáveis à satisfação das carências básicas da população no campo de alimentação, saúde, educação e habitação" (BONAVIDES, P. ANDRADA, P. 1991, p. 801).

Assim, aos 27 dias de novembro de 1985, através da Emenda Constitucional ํo. 26 - promulgada conjuntamente pela CD e pelo SF realizava-se a Convocação da ANC. No Art. $1^{\circ}$ da EC 26, estabeleceu-se a reunião 'livre' e 'soberana' dos constituintes em 19 de fevereiro de 1987, sobre presidência inicial e temporária do presidente do STF. Previu, ainda, a 'promulgação' do texto, após dois turnos de discussão e votação, por maioria absoluta dos membros da ANC. A EC 26 foi importante, ademais, no processo de redemocratização do país, ao conceder anistia aos perseguidos por motivação política (EC 26 de 27/11/85). Iniciava-se, assim, o processo constituinte de elaboração da nova Constituição do Brasil.

\section{O PROCESSO CONSTITUINTE}

Em razão da complexidade que permeia a elaboração de uma nova Constituição, de modo congressional, contando com um número expressivo de constituintes, fez-se necessário, nesta pesquisa, um maior entendimento dos mecanismos de funcionamento da ANC. Um dos trabalhos mais relevantes neste aspecto, que inclusive tem sido fonte de várias pesquisas, trata-se do 
estudo elaborado por Mauro Márcio Oliveira (1993), assessor legislativo do Senado Federal, que reuniu em uma compilação os processos de funcionamento. Tal grandiosidade é retratada, segundo o pesquisador, pelos expressivos números dos acervos decorrentes da ANC 87/88: 212 mil registros eletrônicos relativos a emendas, projetos e destaques, 2 mil caixas de documentos originais, 308 exemplares do "Diário da Assembleia Nacional Constituinte", 215 fitas de videocassete, 1.270 fotos e 2.865 fitas sonoras de gravação dos trabalhos, além dos documentos catalogadas pelas bibliotecas. (M. OLIVEIRA, 1993).

Os trabalhos da Assembleia Nacional Constituinte 87/88 perduraram de $1^{\circ}$ de fevereiro de 1987 a 5 de outubro de 1988, quando foi promulgada a Constituição Federal de 1988. Desenvolveu-se em 7 etapas, que decorreram em 25 (se contarmos a inicial) fases distintas. Oliveira (1993) elaborou uma sistematização das etapas, que adaptamos no quadro abaixo:

Tabela 9: Quadro: Organização dos Trabalhos da ANC 87/88

\begin{tabular}{|c|c|c|c|}
\hline & Etapas & & Fases \\
\hline Etapa 1 & Preliminar & (inicial) & $\begin{array}{l}\text { - Definição do Regimento Interno da ANC } \\
\text { - Sugestões: Cidadãos, Constituinte e Entidades } \\
\text { Anteprojeto do Relator }\end{array}$ \\
\hline Etapa 2 & Subcomissões Temáticas & 1 a 3 & $\begin{array}{l}\text { Emenda ao Anteprojeto do Relator } \\
\text { Anteprojeto da Subcomissão } \\
\text { Emenda ao Anteprojeto da Subcomissão; na } \\
\text { Comissão }\end{array}$ \\
\hline Etapa 3 & Comissões Temáticas & 4 a 7 & $\begin{array}{l}\text { Substitutivo do Relator } \\
\text { Emenda ao Substitutivo } \\
\text { Anteprojeto da Comissão } \\
\text { Anteprojeto de Constituição } \\
\text { Emenda Mérito (CS) ao Anteprojeto } \\
\text { Emenda Adequação (CS) ao Anteprojeto }\end{array}$ \\
\hline Etapa 4 & $\begin{array}{l}\text { Cistematização - CS } \\
\text { Sissao de }\end{array}$ & 8 a 15 & $\begin{array}{l}\text { Emenda (1P) de Plenário e Populares } \\
\text { Substitutivo } 1 \text { do Relator } \\
\text { Emenda ao Substitutivo (ES) } 1 \\
\text { Substitutivo } 2 \text { do Relato } \\
\text { Projeto A (início } 1 .^{\circ} \text { turno) } \\
\text { Ato das Disposições Transitórias }\end{array}$ \\
\hline Etapa 5 & Plenário & $\begin{array}{c}16^{39} a \\
21\end{array}$ & $\begin{array}{l}\text { Emenda }(2 \mathrm{P}) \text { de Plenário } \\
\text { Projeto } \mathrm{B}\left(\text { fim } 1 .^{\circ} \text {; início } 2 .^{\circ} \text { turno) }\right. \\
\text { Emenda }(2 \mathrm{~T}) \text { ao Projeto } \mathrm{B} \\
\text { Projeto } \mathrm{C} \text { (fim } 2 .^{\circ} \text { turno) }\end{array}$ \\
\hline Etapa 6 & Comissão de Redação & 22 e 23 & $\begin{array}{l}\text { Proposta exclusivamente de redação } \\
\text { Proieto D - redacão final }\end{array}$ \\
\hline Etapa 7 & Epílogo & 24 & Promulgação \\
\hline
\end{tabular}

${ }^{39}$ A partir da fase 16 teve início um novo Regimento Interno. 


\section{O PLEITO ELEITORAL}

Sob condições fundamentalmente diferentes das Constituições precedentes, a preparação da Constituição Federal de 1988 foi realizada, extraordinariamente, sob amplo corpo eleitoral, segundo cita Walter Costa Porto, ex-presidente do Tribunal Superior Eleitoral, no preâmbulo da coletânea das "Constituições Brasileiras" publicada pelo Senado Federal, em 2015. O alargamento eleitoral no país alcançou a marca de 69 milhões de votantes habilitados no pleito de $1986^{40}$. (TACITO, C. 1988).

Durante a Chefia de Governo, exercida interinamente no período de 15 de março a 21 de abril de 1985, o presidente José Sarney deu início as medidas de convocação da ANC, através da Mensagem Presidencial ํ․ 330, de 28 de junho de 1985, submetida em proposta ao Poder Legislativo, que originou na Emenda Constitucional №. 26 de 27 de novembro de 1985 de convocação dos constituintes. As pautas dos debates da campanha eleitoral de $1986^{41}$ orbitaram, expressivamente, em torno disso, gerando uma grande renovação no Congresso Nacional (GUIMARÃES, U., 1987).

Esperava-se, segundo Ulysses Guimarães - presidente da Assembleia Nacional Constituinte - a realização de uma nova Constituição desde o regime autoritário, ideia defendida por Tancredo de Almeida Neves, então candidato à presidência, e seus correligionários a fim de "reduzir o hiato democrático do período de 1964 a 1984, indo ao encontro das lídimas aspirações nacionais". (ibid, 1987).

A compilação de trabalhos ${ }^{42}$, fotográficos e jornalísticos, intitulada "Sociedade no Parlamento", apresentou o estabelecimento da primeira sessão,

\footnotetext{
${ }^{40} \mathrm{~A}$ evolução do eleitorado brasileiro pode ser mais bem compreendida, ainda, segundo Walter Costa Porto: em 1872, realizou-se o primeiro recenseamento no país, indicando uma população de aproximadamente 10 milhões de habitantes; contudo, ainda em 1889 eram apenas 200 mil eleitores. Em 1910, foi realizada a "primeira eleição verdadeiramente disputada" que contou com a disputa entre Hermes da Fonseca e Rui Barbosa, com 700 mil eleitores, cerca de $3 \%$ do eleitorado. Somente na escolha da Assembleia Nacional Constituinte de 1946, os eleitores representaram mais de $10 \%$ da população (TÁCITO, C. 1998).

41 As eleições ocorreram em 15 de novembro de 1986.

42 Em 2008, o Centro de Informação e Documentação da Câmara dos Deputados reuniu e publicou a edição intitulada "Sociedade no Parlamento", fruto do trabalho do Serviço Fotográfico da CD, que registrou no período entre 1987 e 1988, aproximadamente 28 mil fotos, que traduzem, com riqueza, a intensa atividade parlamentar e popular no processo constituinte.
} 
unicameral, presidida pelo presidente do Supremo Tribunal Federal, em $1^{\circ}$ de fevereiro de 1987, como “(...) um passo decisivo na superação do regime autoritário implantado em 1964, uma vitória do movimento pela democratização do país". (BACKES, 2008). Destacou-se, a deferência à participação social, cuja importância deu-se no embasamento e intuito da edição publicada pela Câmara dos Deputados.

Um dos estudos da professora Dallari (2009) traçou os caminhos da construção da saúde no Brasil, destacando a importância atribuída à questão da saúde na Constituição Federal de 1988. Tal destaque ocorreu, especialmente, em razão de grande participação popular, através de movimentos da sociedade civil. A introdução da saúde neste rol de direitos sociais deve-se a força imprescindível dos movimentos populares no processo de redemocratização do país (DALLARI, S. G., 2009). Os movimentos sociais, segundo Aith, conseguiram inserir grande parte de seus anseios na nova Constituição. Isto pôde ser entendido como um "fôlego", até então não atingido pelo Direito Sanitário no Brasil. (AITH, 2006).

\section{OS PARTIDOS POLÍTICOS NA ANC 1988}

No quadro abaixo é possível identificar a composição da ANC, em razão das bancadas partidárias. Observa-se a disparidade de representantes entre os partidos maiores (PMDB e PFL) e os menores (PSC e PMB). O PMDB contou com $303(54,2 \%)$ representantes na ANC, representando mais da metade dos constituintes. O PSDB foi criado durante a constituinte, em junho de 1988.

Tabela 10: Composição das Bancadas Partidárias na instalação da ANC de 198788

\begin{tabular}{|c|c|c|c|c|c|c|c|c|c|c|c|c|c|c|}
\hline \multicolumn{15}{|c|}{ Composição das bancadas partidárias na instalação da ANC ${ }^{43}$ de 1987-88. } \\
\hline Partido & PMDB & PFL & PDS & PDT & РTB & PT & $\mathrm{PL}$ & PDC & PCB & $\begin{array}{l}\text { PCdo } \\
\text { B }\end{array}$ & PSB & PSC & PMB & TOTAL \\
\hline Bancada & 303 & 135 & 38 & 26 & 18 & 16 & 07 & 06 & 03 & 03 & 02 & 01 & 01 & 559 \\
\hline
\end{tabular}

\footnotetext{
${ }^{43}$ Levantamento feito pela edição "Sociedade no Parlamento".
} 
Destacou-se nesse período a atuação de um bloco suprapartidário, com viés de centro e direita, criado no final do primeiro ano da Constituinte (1987), conhecido como 'Centrão'. O objetivo do bloco, formado após a dissidência da Aliança Democrática (PMDB-PFL), era a priori prestar apoio ao Governo Sarney. Inicialmente, o bloco era composto por lideranças do PMDB, PFL, PDS e PTB, que juntos somavam 494 (88,4\%) parlamentares.

A relação do grupo e o planalto, contudo, que antes era basilar ao governo e garantiu os 05 anos de mandato a José Sarney, ficou abalada no decorrer do processo constituinte. Alguns parlamentares conseguiram ocupar funções importantes no Governo (com cargos e verbas), mas marcaram uma derrocada com o avanço da impopularidade do presidente e o acirramento das crises social e econômica, aliadas às denúncias de corrupção. Muitos migraram em apoio ao candidato Fernando Collor de Mello, nas eleições de 1989. Dentre os líderes do Centrão estavam dois representantes das classes sanitárias: Carlos Santana (PMDB - BA) e Daso Coimbra (PMDB - RJ).

PMDB e PFL enquanto maiores partidos, aglutinaram também o maior número de constituintes provenientes das carreiras sanitárias. No quadro abaixo, temos a correlação de parlamentares por partidos políticos, dentre os profissionais de saúde: 
Figura 5: Gráfico: número de deputados(as) x partido

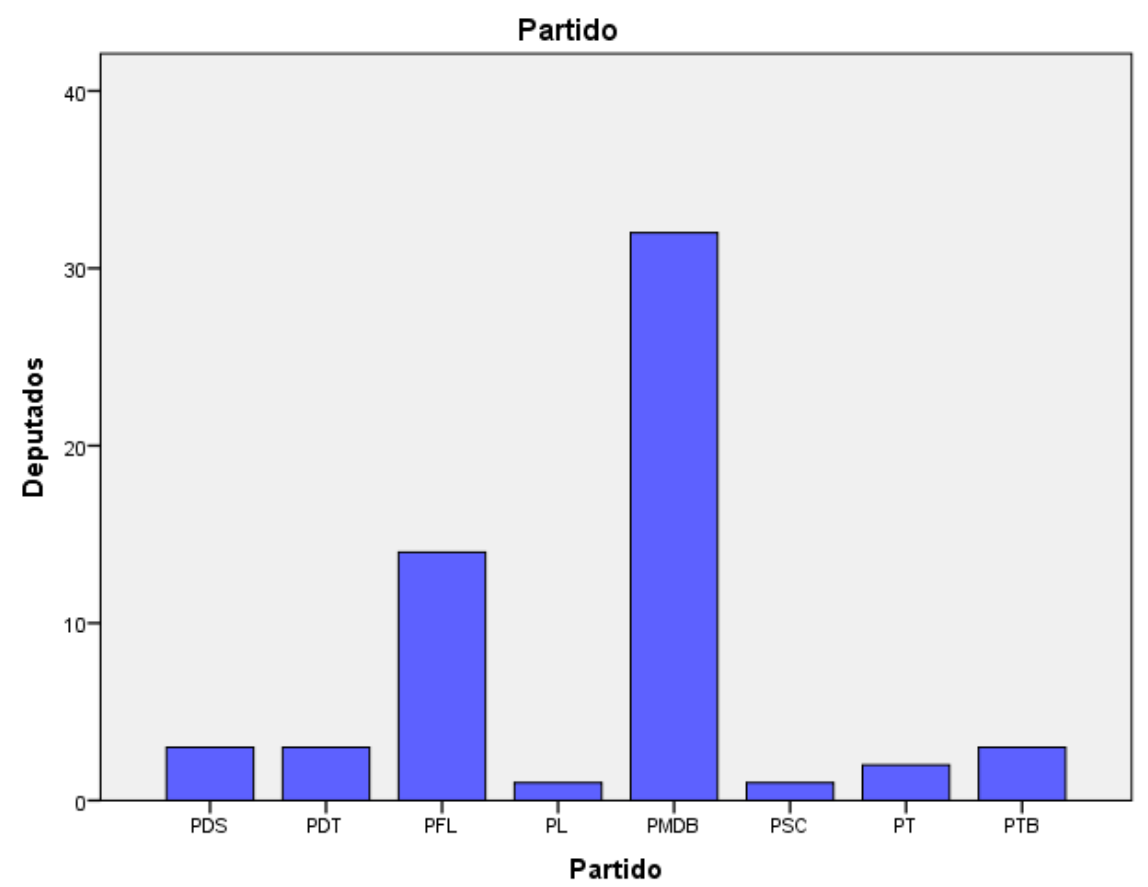

\section{PERFIL REGIONAL}

No quadro global da $\mathrm{ANC}^{44}$, os parlamentares das regiões Norte, Nordeste e Centro-Oeste tinham maioria na Constituinte (292, num total de 559). No Senado, cada Estado tinha 3 representantes, e os territórios, Roraima e Amapá, nenhum. Deputados por unidade da Federação: Norte: Acre (8) Amazonas (8) Pará (17), Rondônia (8) Roraima (4) e Amapá (4), Nordeste: Alagoas (9), Bahia (39), Ceará, (22), Maranhão (18), Paraíba (12), Pernambuco (25), Piauí (10), Rio Grande do Norte. (8) e Sergipe (8), Centro-Oeste: Distrito Federal (8) Goiás (17), Mato Grosso (8) e Mato Grosso do Sul (8).

Ao analisarmos o perfil regional dos constituintes, atrelado ao perfil sanitarista, temos predominância de representantes da região Sudeste. Na tabela abaixo, temos a frequência e percentual de representantes (deputados e deputadas constituintes) dentre as profissões classificadas como sanitárias:

\footnotetext{
${ }^{44}$ Considerando-se apenas os titulares das vagas.
} 
Tabela 11: Quadro: Perfil regional dos(as) deputados(as) constituintes - CF $87 / 88$

\begin{tabular}{|c|c|c|c|}
\hline \multicolumn{4}{|c|}{ Deputados e Deputadas Constituintes - Perfil Regional } \\
\hline Estado & UF & Frequência & Percentual \\
\hline Acre & $\mathrm{AC}$ & 1 & 1,7 \\
\hline Bahia & BA & 6 & 10,2 \\
\hline Ceará & CE & 4 & 6,8 \\
\hline Distrito Federal & DF & 2 & 3,4 \\
\hline Espírito Santo & ES & 1 & 1,7 \\
\hline Goiás & GO & 1 & 1,7 \\
\hline Maranhão & MA & 1 & 1,7 \\
\hline Minas Gerais & MG & 9 & 15,3 \\
\hline Mato Grosso do Sul & MS & 1 & 1,7 \\
\hline Mato Grosso & MT & 2 & 3,4 \\
\hline Paraíba & PB & 1 & 1,7 \\
\hline Pernambuco & $\mathrm{PE}$ & 2 & 3,4 \\
\hline Paraná & PR & 6 & 10,2 \\
\hline Rio de Janeiro & RJ & 3 & 5,1 \\
\hline Rio Grande do Norte & $\mathrm{RN}$ & 1 & 1,7 \\
\hline Rondônia & $\mathrm{RO}$ & 1 & 1,7 \\
\hline Roraima & $\mathrm{RR}$ & 2 & 3,4 \\
\hline Rio Grande do Sul & RS & 3 & 5,1 \\
\hline Santa Catarina & $\mathrm{SC}$ & 3 & 5,1 \\
\hline Sergipe & SE & 2 & 3,4 \\
\hline São Paulo & SP & 7 & 11,9 \\
\hline & Total & 59 & 100,0 \\
\hline
\end{tabular}

$\mathrm{Na}$ análise seguinte, é possível perceber a disposição dos (as) representantes em razão da região, com maior número de representantes nas 
regiões Nordeste e Sudeste. No perfil sanitarista, observamos a ausência de representantes dos Estados do Amazonas, Pará, Amapá, Tocantins, Alagoas e Piauí.

Tabela 12: Percentual de Constituintes Sanitaristas $x$ Região

Perfil regionalizado da composição da ANC 1988, segundo o perfil sanitário

\begin{tabular}{lccccc}
\hline Região & Norte & $\begin{array}{c}\text { Centro- } \\
\text { Oeste }\end{array}$ & Sul & Nordeste & Sudeste \\
Constituintes & $04(6,8 \%)$ & $06(10,2 \%)$ & $12(20,4 \%)$ & $17(28,9 \%)$ & $20(34 \%)$ \\
\hline
\end{tabular}

Na demonstração global, percebe-se a incidência dos estados de Minas Gerais (maior número de representantes sanitaristas) e, em segundo lugar, São Paulo, seguidos de Paraná e Bahia, ambos com 6 representantes.

Figura 6: Frequência de Constituintes x UF

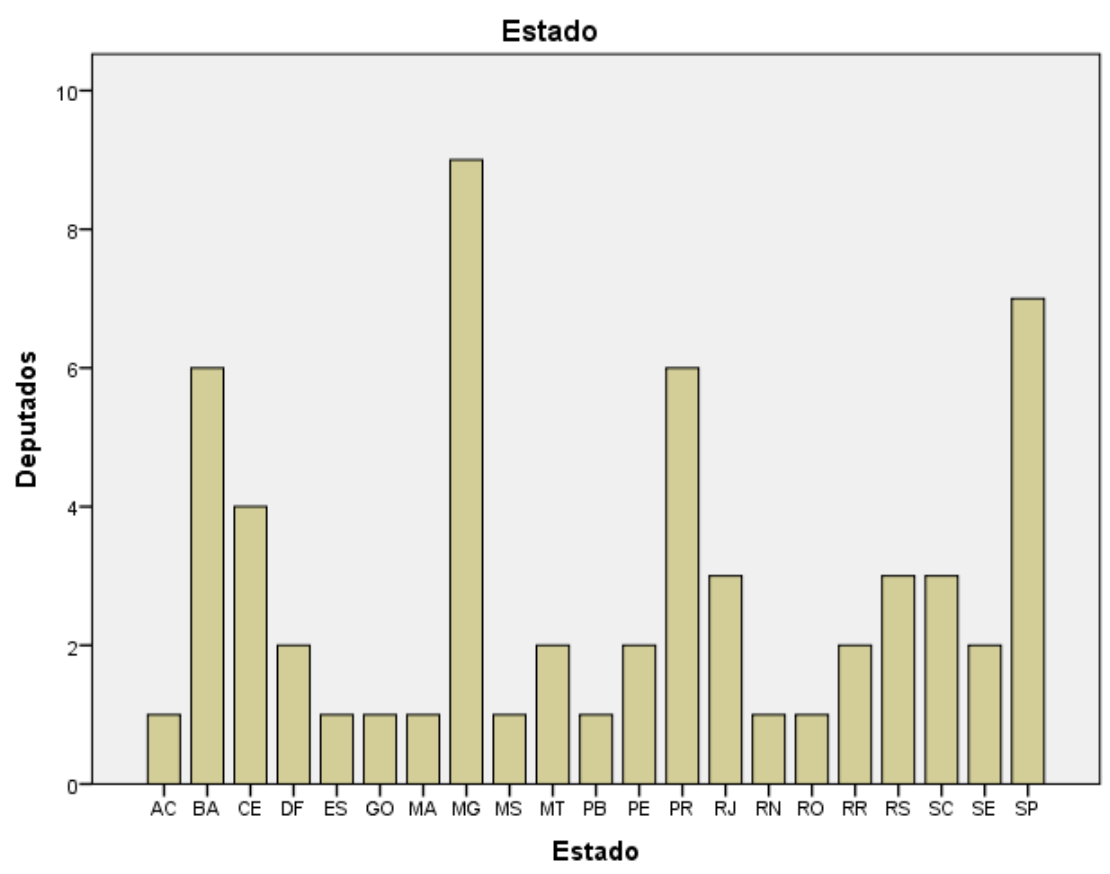




\section{O PERFIL SANITARISTA NA ANC (87/88)}

A grande inovação da Constituição de 88 , que deu novo significado à 'saúde', foi a marca cidadã enunciada até mesmo no discurso de promulgação. A participação de diversos setores da sociedade civil organizada representou uma diversidade de pensamentos e o fortalecimento de causas populares, como do direito à saúde. Evidentemente, isso ocorreu em razão de dois fatores. Primeiramente, diferente das Constituições antecessoras, a CF 88 foi elaborada, como já vimos, sob uma significativa ampliação do corpo eleitoral e do quadro de constituintes, preenchido por profissionais de diversos setores. Além disso, outro aspecto deve ser considerado, especialmente na área da saúde: as lutas sanitárias nesse período ganharam mais escopo, dentre outros fatores, fruto das lutas da 8ª Conferência Nacional de Saúde. Havia, ainda, uma nova consciência do conceito de saúde, ampliada desde a Declaração da Organização das Nações Unidas.

No bojo das motivações democráticas de renovação política no país, a inserção de novos atores no quadro político representou novos avanços de representatividade e inclusão de pautas, frutos da mobilização popular e de setores organizados. A presença de profissionais ligados à saúde não sinalizou, contudo, o crescimento da pauta sanitária no texto constitucional, como veremos a seguir. Dentre os 512 deputados constituintes, 59 (11,52\% do total) eram formados e/ou trabalhavam em profissões ligadas à área da saúde, segundo informaram à Câmara dos Deputados. Esse número é um pouco menor do que em 1946, mas segue uma tendência.

O estudo demonstrou que mesmo com profissionais da saúde nas ANCs isso não é uma condição sine qua non do avanço da pauta sanitária. Pois são encontradas diversas situações: não sanitaristas agindo em prol de pautas sanitárias; sanitaristas atuando exclusivamente em outras áreas e expoentes isolados, como Eduardo Jorge, aglutinando grandes demandas e enunciando debates cruciais.

O estudo mais recente do cientista político Leôncio Martins Rodrigues (2006), a despeito das mudanças na classe política brasileira, debruçou-se 


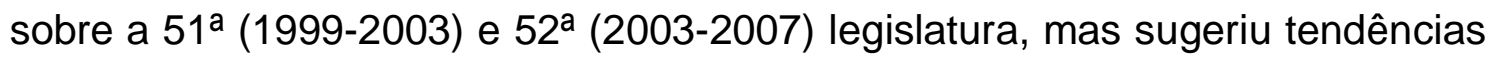
quanto à dinâmica de composição das casas legislativas de modo geral. Nesse levantamento, uma das hipóteses aventadas é, justamente, de que a importância dos grupos econômicos e profissionais dentro das casas legislativas depende do perfil social dos partidos vencedores e perdedores. $\mathrm{Ou}$ seja, a presença de partidos políticos ideologicamente de direita, em geral, aumenta a incidência de empresários e representantes da classe alta. E, por conseguinte, o aumento de partidos de esquerda eleva a presença de professores, sindicalistas, servidores públicos e trabalhadores manuais (Rodrigues, 2006, p. 17).

A pesquisa desenvolvida por Rodrigues (2009), no recorte que a aproxima da temática saúde, revelou a presença de significativo percentual de profissionais liberais na $51^{\text {a }}$ e $52^{\text {a }}$ legislatura. Esses profissionais aparecem como segundo grupo de maior importância, em número de representantes, na Câmara dos Deputados. O número de médicos representou o grupo mais significativo, contando com 12 e $11 \%$ de representantes, respectivamente, nas $51^{\text {a }}$ e $52^{\text {a }}$ legislaturas da Câmara dos Deputados. Segundo Rodrigues (2009), esses dados "sugerem que a própria atividade médica (em hospitais públicos e outras instituições de saúde, além de postos importantes em órgãos do Estado ligados à rede de saúde) pode ser um bom trampolim para a entrada na vida pública. O Brasil, aliás, possui tradição de ter médicos entre grandes chefes políticos. Para citar apenas alguns poucos exemplos mais conspícuos: Adhemar de Barros (...) Juscelino Kubitschek (...)" (RODRIGUES, 2009).

Outro estudo mais recente de Vial, é relevante, sobretudo, pela eficiência do aspecto metodológico aplicado traçaram o perfil das classes profissionais dos parlamentares da Câmara dos Deputados, no período entre a

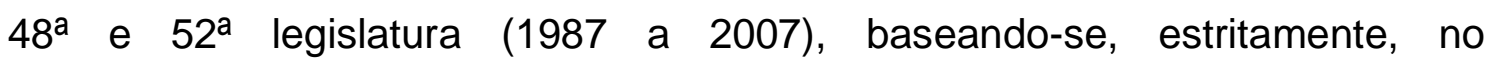
levantamento dos dados e sua, posterior, análise. A partir dos dados levantados, podemos aferir que das 28 profissões/ocupações, entre os 589 deputados da época, entre ocupantes de vaga e suplentes, 54 eram médicos $(9,16 \%)$, 3 farmacêuticos $(0,50 \%)$, e 3 assistentes sociais $(0,50 \%)$. Alguns 
parlamentares também se identificaram em mais de uma profissão (VIAL, 2007).

Enquanto na $52^{\mathrm{a}}$ legislatura, compreendida no período de 2003 a 2007, foram analisados os perfis profissionais de 629 deputados, entre titulares e suplentes que vieram a assumir uma vaga. Sendo possível aferir 46 profissões, frente às 28 da legislatura comparada, nas seguintes ocupações ligadas à saúde: 73 médicos $(11,60 \%)$ - 4a posição, 3 enfermeiras $(0,47 \%), 1$ farmacêutica $(0,15 \%)$. É interessante notar as relações de gênero neste contexto, em que há a presença de 3 enfermeiras e 1 farmacêutica. O número reduzido e descrito no gênero feminino releva a baixa e desigual representatividade das mulheres no Parlamento. Esse estudo permitiu, ainda, concluir que houve uma mudança, com a redução de seguimentos tradicionais e a inclusão de novas profissões/ocupações na Câmara dos Deputados. A profissão/ocupação mais presente foi a de advogado, porém a descrição "médico" ocupou a $6^{\mathrm{a}}$ e $4^{\mathrm{a}}$ posição nas $48^{\mathrm{a}}$ e $52^{\mathrm{a}}$ legislatura, respectivamente (ibid, 2007).

\section{Figura 7: Quadro Profissional dos Constituintes de 87/88 em relação à área da} saúde

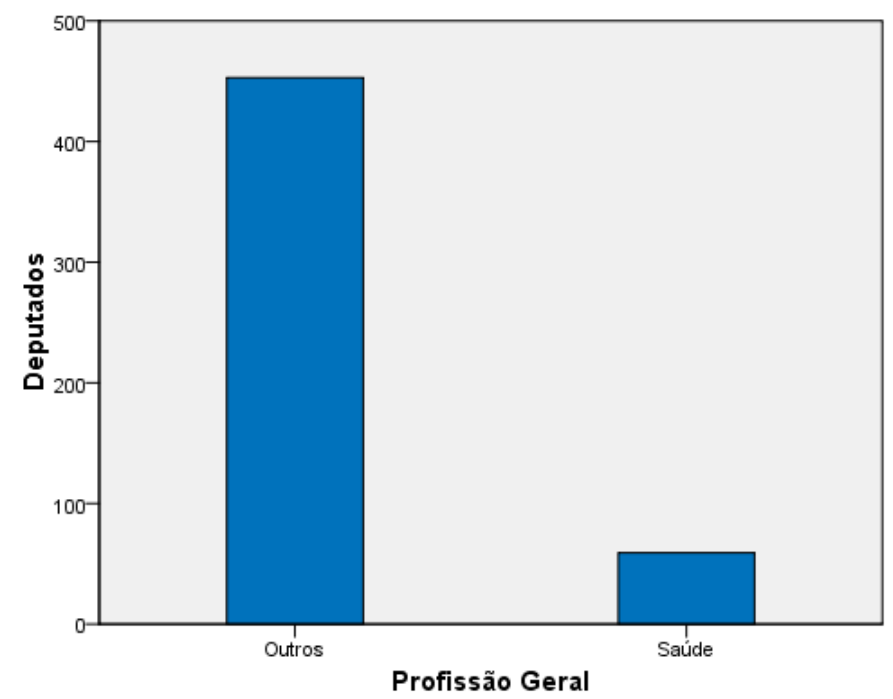

Ao analisarmos especificamente dentre as profissões da área da saúde, temos que a classe médica correspondeu $74,6 \%$ dos membros da ANC $87 / 88$. 
Isso revela a forte mobilização deste seguimento e, por outro lado, uma tendência em eleger médicos a cargos representativos, associado possivelmente à imagem de figuras de importância social, benevolentes e sábias.

Figura 8: Distribuição das profissões na área da saúde dos parlamentares que participaram da constituinte de 1988 - Deputados

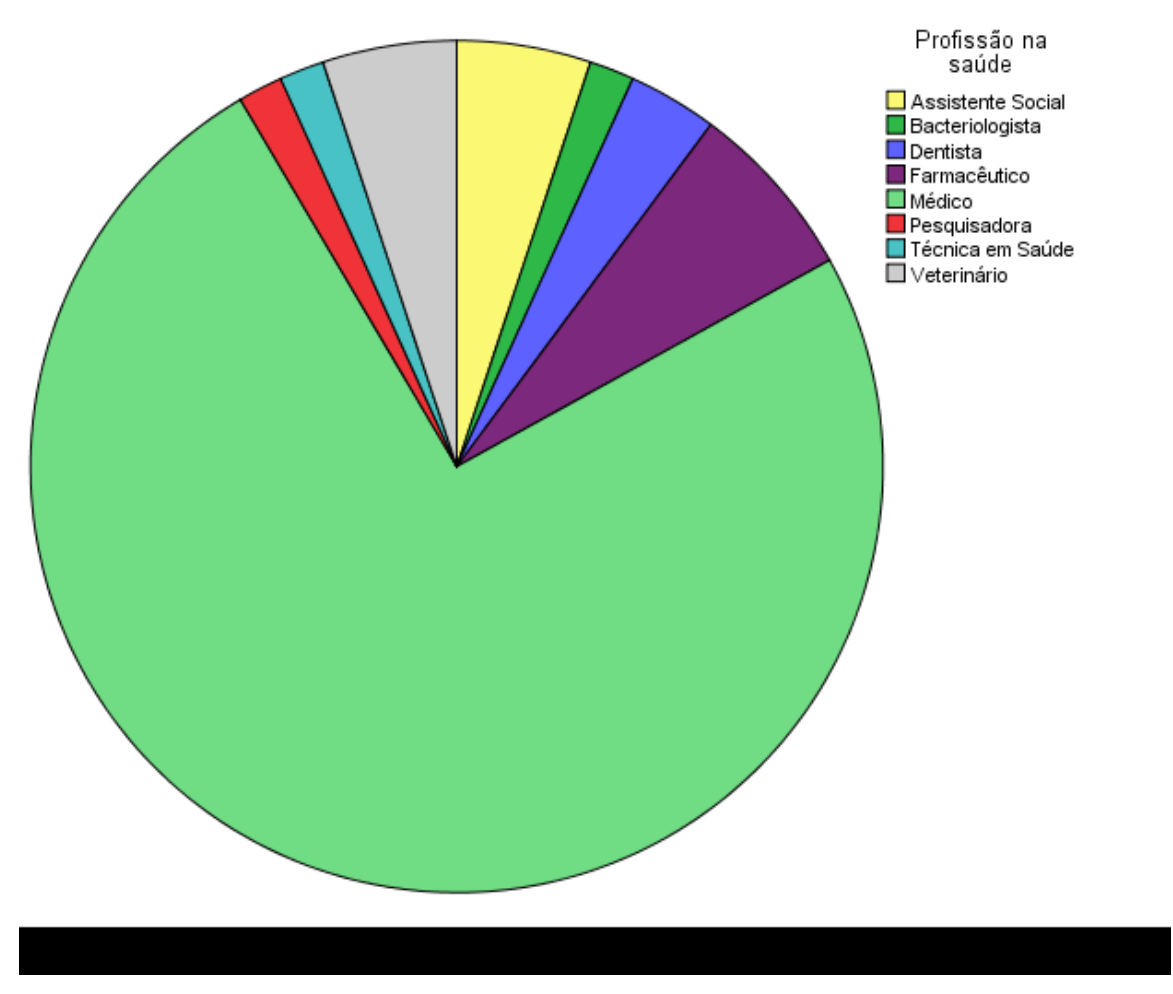

Outras profissões também contaram com representação. Farmacêuticos contaram com 4 membros, Veterinários e Assistentes Sociais, ambas com 3, Dentista 2, enquanto Pesquisadora, Bacteriologista e Técnica de Saúde possuíram, cada uma, um representante. 
Tabela 13: Distribuição das profissões na área da saúde dos parlamentares que participaram da constituinte de 1988 - Deputados

\begin{tabular}{ccc}
\hline \multicolumn{3}{c}{ Parlamentares com profissão na área da saúde } \\
\hline Profissão & $\begin{array}{c}\text { Frequência } \\
\text { Absoluta }\end{array}$ & Porcentagem \\
\hline Médica & 44 & 74,6 \\
Farmacêutico & 4 & 6,8 \\
Veterinário & 3 & 5,1 \\
Assistente Social & 3 & 5,1 \\
Dentista & 2 & 3,4 \\
Pesquisadora & 1 & 1,7 \\
Técnica em Saúde & 1 & 1,7 \\
Bacteriologista & 1 & 1,7 \\
Total & 59 & 100,0 \\
\hline
\end{tabular}

6. A PARTICIPAÇÃO DAS MULHERES NA ANC (87/88)

Em relação às Constituições precedentes, houve significativo alargamento da participação feminina na realização dos trabalhos constituintes de 88 , ainda que o número de deputadas seja mínimo frente à presença massiva de representantes do sexo masculino. Foram, ao total, 26 deputadas constituintes e nenhuma senadora, frente a 486 deputados e 82 senadores. 
Figura 9: Gráfico relação de gênero na composição da ANC 87/88

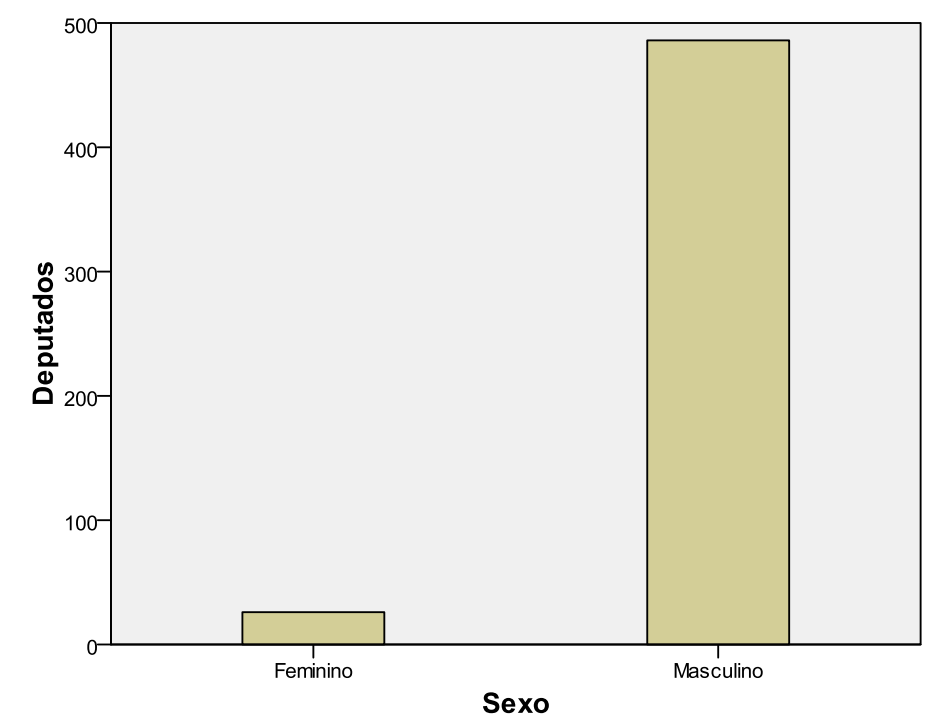

Quanto ao percentual de gênero, na composição geral da ANC 87/88, temos que $95 \%$ dos membros eram do gênero masculino, enquanto apenas 05\% eram representantes do gênero feminino, conforme tabela abaixo:

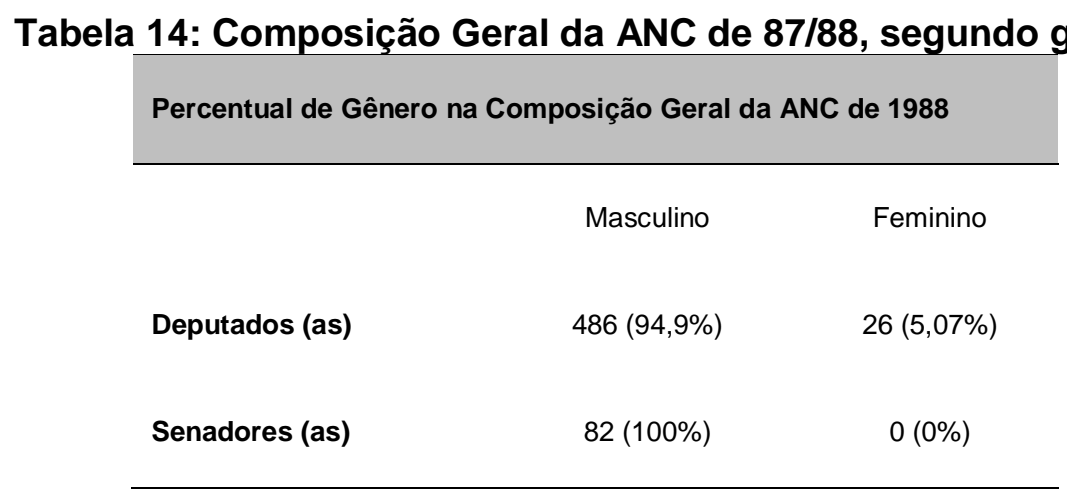

O número reduzido de representantes não ofuscou, contudo, a participação ativa da bancada feminina na formulação da carta constitucional. Trabalhos como o de Nelsina Melo Dias (1991), da Universidade Federal da Paraíba, evidenciam a participação das mulheres na condução da saúde pública no Brasil. "Mulheres: sanitaristas de pés descalços" fala sobre a mulher da classe operária e sua batalha diária na prática sanitária em suas comunidades. Essa preocupação feminina com a pauta sanitária se reflete 
também na ANC. Dentre as profissões sanitárias, temos, segundo o gênero, a seguinte frequência:

Tabela 15: Frequência de gênero na ANC x profissões sanitaristas

\begin{tabular}{lcc} 
& Frequência & Percentagem \\
\hline Feminino & 7 & 11,9 \\
Masculino & 52 & 88,1 \\
Total & 59 & 100,0 \\
\hline
\end{tabular}

Das profissionais do gênero feminino que compuseram a ANC, $26 \%$ provinham de profissões ligadas à área da saúde, enquanto apenas $9 \%$ dos profissionais que declararam-se do gênero masculino, possuíam formação ou atuavam em profissões sanitárias. Como vimos anteriormente, o pleito de 1986, realizado no contexto de redemocratização do país, foi marcado por uma ampliação do corpo eleitoral, com expressivo número de candidatos e eleitores. O número de mulheres eleitas foi, na ocasião, o maior se comparado as Constituições anteriores. A CF 88 é considerada um marco na participação feminina.

A primeira Constituição a contar com a participação feminina, por exemplo, foi a de 1934, na Era Vargas, com uma única mulher em meio a 214 deputados - as Constituições posteriores a 1934 e anteriores a 1988 não constaram a participação de deputadas ou senadoras em sua elaboração. Em 1986, foram eleitos 536 constituintes, sendo 487 à Câmara dos Deputados e 49 ao Senado Federal, somando-se aos 23 senadores, que foram eleitos em 1982 ao mandato de oito anos, totalizando-se 559 membros à ANC. A $47^{\text {a }}$ legislatura (1983-87) contou com apenas sete parlamentares provenientes da área da saúde, frente às 26 eleitas em 1986 para a ANC 87/88.

Evidencia-se a atuação feminina em diversos trabalhos, dentre estes Costa, Bahia e Conte (2007) destacaram a busca por novos espaços de participação e atuação das mulheres, que na década de 80 conquistaram a criação de conselhos (nacional e estaduais) de atenção à mulher, além das delegacias de defesa da mulher. Segundo as pesquisadoras: 
"A participação de sanitaristas feministas, comprometidas com as instâncias relacionadas ao setor da Saúde, aliadas às representações femininas na Câmara Federal e no Poder Legislativo de estados e municípios, fortaleceu o debate nos fóruns, organizados pelos movimentos de mulheres, e no movimento sanitário pela necessidade de mudanças profundas no sistema da Saúde" Costa, Bahia e Conte (2007).

A despeito do baixo número percentual de mulheres que compunham a ANC - cerca de 5\% do total de membros, alcançou-se um marco expressivo de participação e atuação feminina. As 26 constituintes compunham um grupo que ficou conhecido com a "bancada feminina" da ANC. No quadro 45 a seguir, é possível identificar a composição do grupo por nome, filiação partidária, profissão e região:

Tabela 16: Composição da Bancada Feminina (nome, partido, estado e profissão)

\begin{tabular}{lccl}
\hline \multicolumn{1}{c}{ NOME } & PARTIDO & ESTADO & \multicolumn{1}{c}{ PROFISSÃO } \\
\hline Abigail Feitosa & PMDB & BA & Médica \\
\hline Anna Maria Rattes & PMDB & RJ & Advogada \\
\hline Benedita da Silva & PT & RJ & $\begin{array}{l}\text { Aux. de Enf./Assist. } \\
\text { Social }\end{array}$ \\
\hline Bete Mendes & PMDB & SP & Atriz \\
Beth Azize & PSB & AM & Advogada \\
Cristina Tavares & PMDB & PE & Jornalista \\
Dirce Tutu Quadros & PSC & SP & Pesquisadora \\
Eunice Michiles & PFL & AM & Professora \\
Irma Passoni & PT & SP & Professora \\
Lídice da Mata & PC DO B & BA & Economista \\
Lúcia Braga & PFL & PB & Assistente Social \\
Lúcia Vânia & PMDB & GO & Jornalista \\
Márcia Kubitschek & PMDB & DF & Jornalista \\
Maria de Lourdes Abadia & PFL & DF & Assistente Social \\
Maria Lúcia & PMDB & AC & Professora \\
Marluce Pinto & PTB & RR & Empresária \\
Moema São Thiago & PDT & CE & Advogada \\
Myriam Portella & PDS & PI & Advogada
\end{tabular}

${ }^{45}$ Elaborado a partir de registros bibliográficos da Câmara dos Deputados, disponíveis em meio eletrônico no sítio www.camara.leg.br (acessado em 13.01.2018). 


\begin{tabular}{lccl} 
Raquel Cândido & PMDB & RO & Técnica em Saúde \\
Raquel Capiberibe & PMDB & AP & Professora \\
Rita Camata & PMDB & ES & Jornalista \\
Rita Furtado & PFL & RO & Jornalista \\
Rose de Freitas & PMDB & ES & Jornalista \\
Sadie Hauache & PFL & AM & Jornalista \\
Sandra Cavalcanti & PFL & RJ & Professora \\
Wilma Maia & PDS & RN & Professora \\
\hline
\end{tabular}

Dentre os partidos políticos, observa-se que o PMDB elegeu um número maior de mulheres no pleito eleitoral de 1986 , onze representantes $(42,3 \%$ do número total de deputadas), seguido do PFL com seis representantes. A Bancada Feminista era composta, ainda, por PDS, PT, PSB, PCdoB, PDT e PSC.

Quanto ao perfil profissional, a Banca Feminista contou com cinco diferentes profissões em sua composição. Destacamos, aqui, as concernentes à área da Saúde. São seis as Deputadas com formação na área de Assistência Social, Técnica de Saúde, Auxiliar de Enfermagem, Médica ou Pesquisadora. Benedita da Silva (PT-RJ) possuía formação em Auxiliar de Enfermagem e, também, em Assistência Social. A constituinte aparece com as duas nomenclaturas profissionais. Dirce Tutu Quadros (PSC-SP), que figura na bibliografia oficial da Câmara dos Deputados como Pesquisadora, formou-se em Ciências e PhD em Citologia pela Universidade do Texas, EUA. No quadro abaixo, encontramos a sistematização do perfil profissional, em termos percentuais:

Tabela 17: Distribuição das profissões na área da saúde dos parlamentares que participaram da constituinte de 1988 - bancada feminina

\begin{tabular}{ccc}
\hline \multicolumn{3}{c}{ Parlamentares com profissão na área da saúde } \\
\hline Profissão & $\begin{array}{c}\text { Frequência } \\
\text { Absoluta }\end{array}$ & Porcentagem \\
\hline Assistente Social & 3 & 42,9 \\
Médica & 1 & 14,3 \\
Pesquisadora & 1 & 14,3 \\
\hline
\end{tabular}




\begin{tabular}{ccc}
\hline Técnica em Saúde & 1 & 14,3 \\
Total & 7 & 100,0 \\
\hline
\end{tabular}

Dentre a Bancada Feminina, as profissões que compunham a área sanitária, destacaram-se pela presença de quase metade (3 constituintes) das constituintes provenientes da Assistência Social (42,9\%), as demais profissões contaram cada uma com uma representante: 01 médica (14,3\%), 01 pesquisadora da área da Citologia (14,3\%) e 01 técnica de saúde (14,3\%).

Figura 10: Distribuição das profissões na área da saúde dos parlamentares que participaram da constituinte de 1988 - bancada feminina

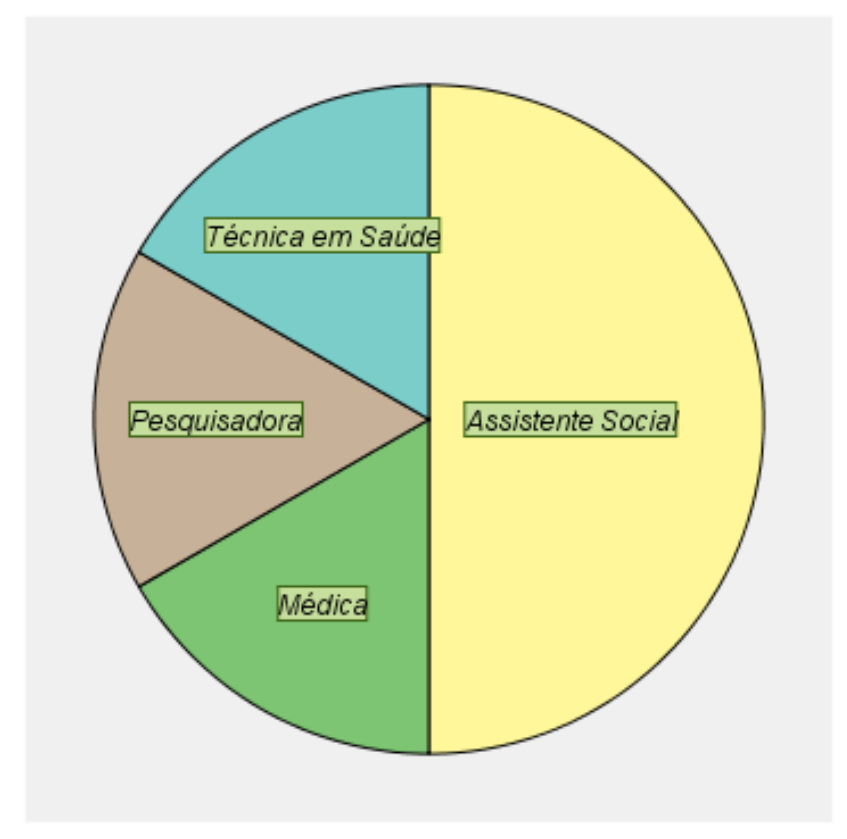

Abigail Feitosa (PMDB-BA), médica, foi Deputada Estadual e médica do INAMPS na Secretaria Estadual de Saúde da Bahia. Foi membro da Subcomissão de Saúde, Seguridade e do Meio Ambiente e da Comissão da Ordem Social (suplente), na ANC 87/88 participou, ainda, da Comissão de Sistematização (titular). Entre 1980-82, foi vice-presidente da Associação 
Baiana de Medicina e, em 1985, Coordenadora-Geral do Movimento de Unidade Popular, o MUP.

Maria Lourdes Abadia (PFL-DF), assistente social, professora, possui titulações internacionais e condecorações, integrou diversas comissões, programas e projetos, além de ocupar vários cargos no legislativo e no executivo. Foi, ainda, vice-presidente da União dos Estudantes de Brasília, DF - 1966-68 e Presidente da União Latino-Americana de Mulheres, em 1999.

Raquel Cândido (PMDB - RO), técnica em saúde, participou de diversas comissões, dentre elas da Subcomissão de Saúde, Seguridade e do Meio Ambiente. No quadro abaixo, é possível ver a participação das sanitaristas em relação à composição total da Bancada Feminina na ANC 87/88:

\section{Figura 11: Gráfico com as profissões das parlamentares que participaram da constituinte de 1988 - bancada feminina}

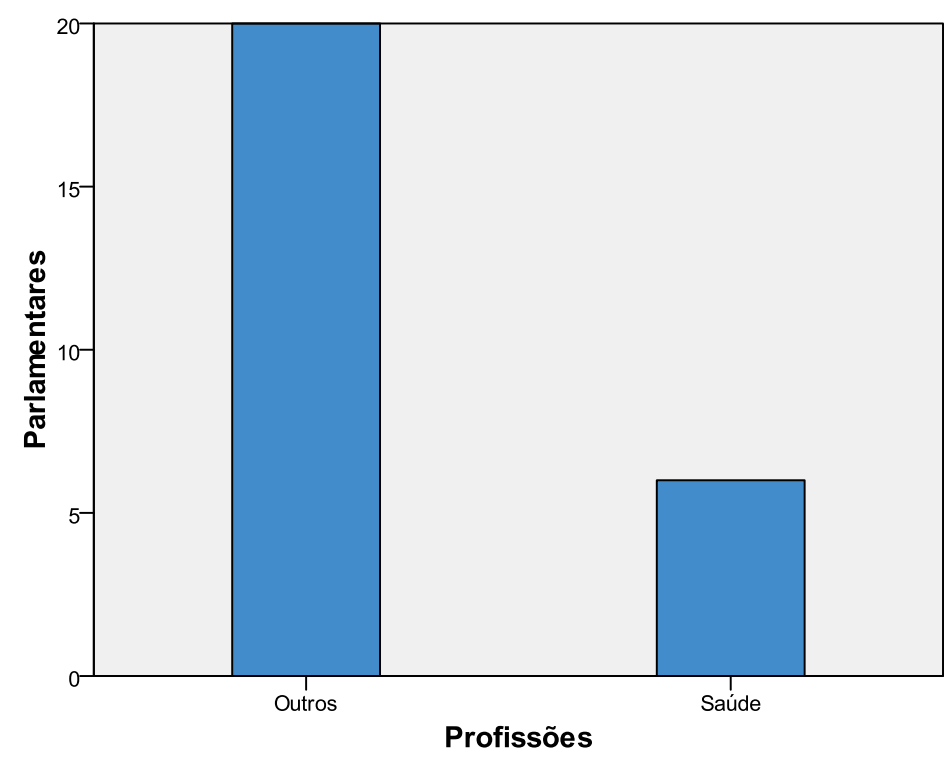

Embora o pleito de 1986 tenha permitido a ascensão de novos candidatos (em primeira eleição), parte dos membros da ANC 87/88 provinha de famílias tradicionais na política, dentre as parlamentares "sanitaristas", destacamos Dirce Tutu Quadros e Lúcia Braga. Dirce era filha de Jânio Quadros, ex-presidente do Brasil, já Lúcia era mulher do ex-governador 
paraibano Wilson Braga). Algumas já haviam ocupado função no legislativo, como Raquel Cândido (ex-vereadora).

\section{ANÁLISE DAS VARIÁVEIS}

A análise do perfil dos constituintes da ANC 87/88 permitiu concluir uma presença maior do gênero masculino, não apenas na composição geral, mas também nas profissões inerentes ao campo da saúde. Enquanto Veterinário, Dentista e Bacteriologista foram representadas apenas pelo gênero masculino, Técnica em Saúde, Pesquisadora e Assistente Social foram representadas apenas pelo gênero feminino. As profissões médica e farmacêutica foram as únicas que contaram com representantes de ambos os gêneros, mantendo-se a predominância masculina. Vejamos na dispersão a seguir: 
Figura 12: Dispersão dos parlamentares profissionais de saúde em relação ao gênero - constituinte de 1988 - Deputados

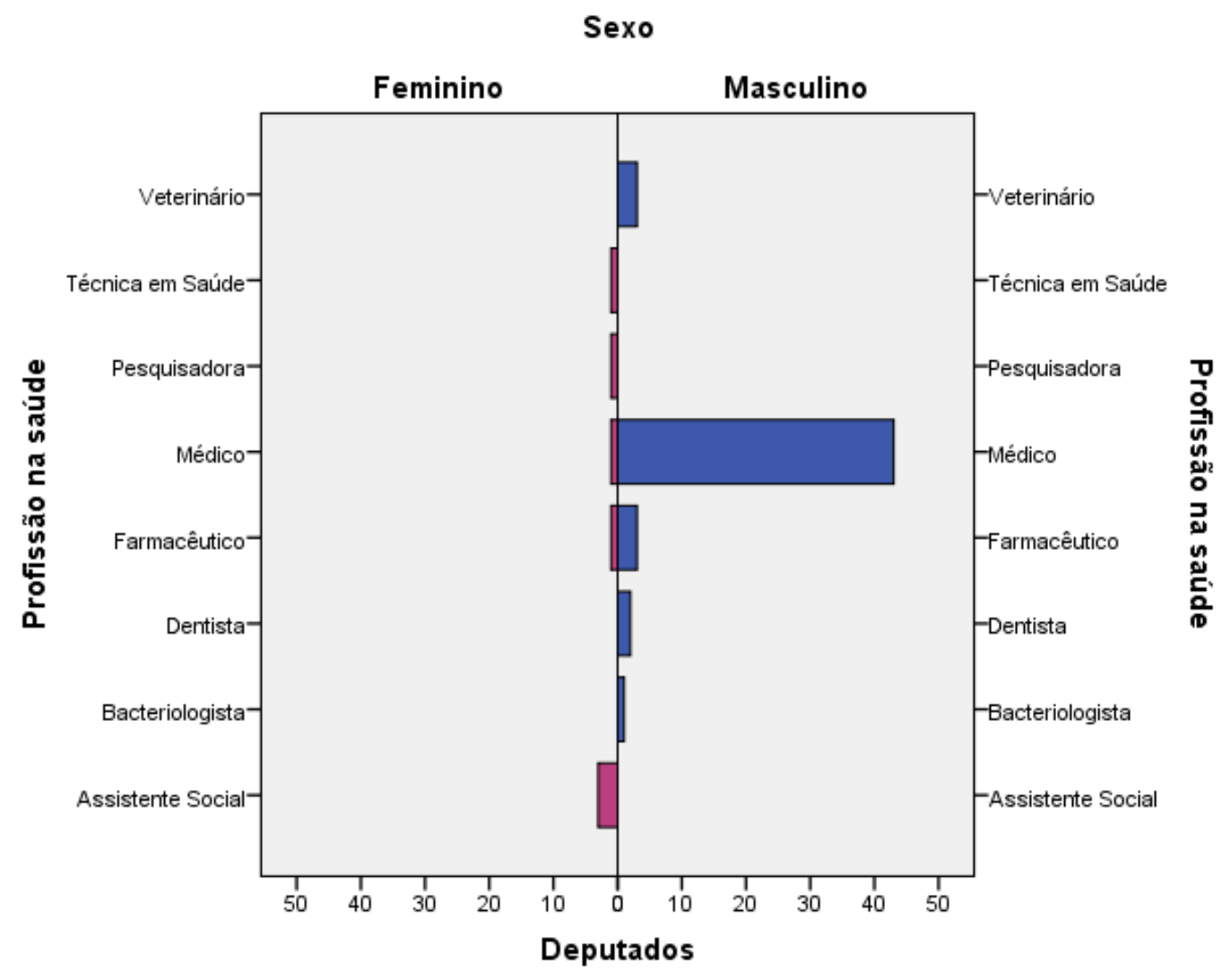

No panorama geral, os Estados de São Paulo, Sergipe, Santa Catarina e Rio Grande do Sul prevaleceram na presença de profissionais da saúde. Dentre as profissões, nestes Estados, o predomínio foi da profissão médica e o maior partido em número de representantes foi o PMDB. 
Figura 13: Dispersão dos parlamentares profissionais de saúde em relação ao partido político e ao estado - constituinte de 1988 - Deputados

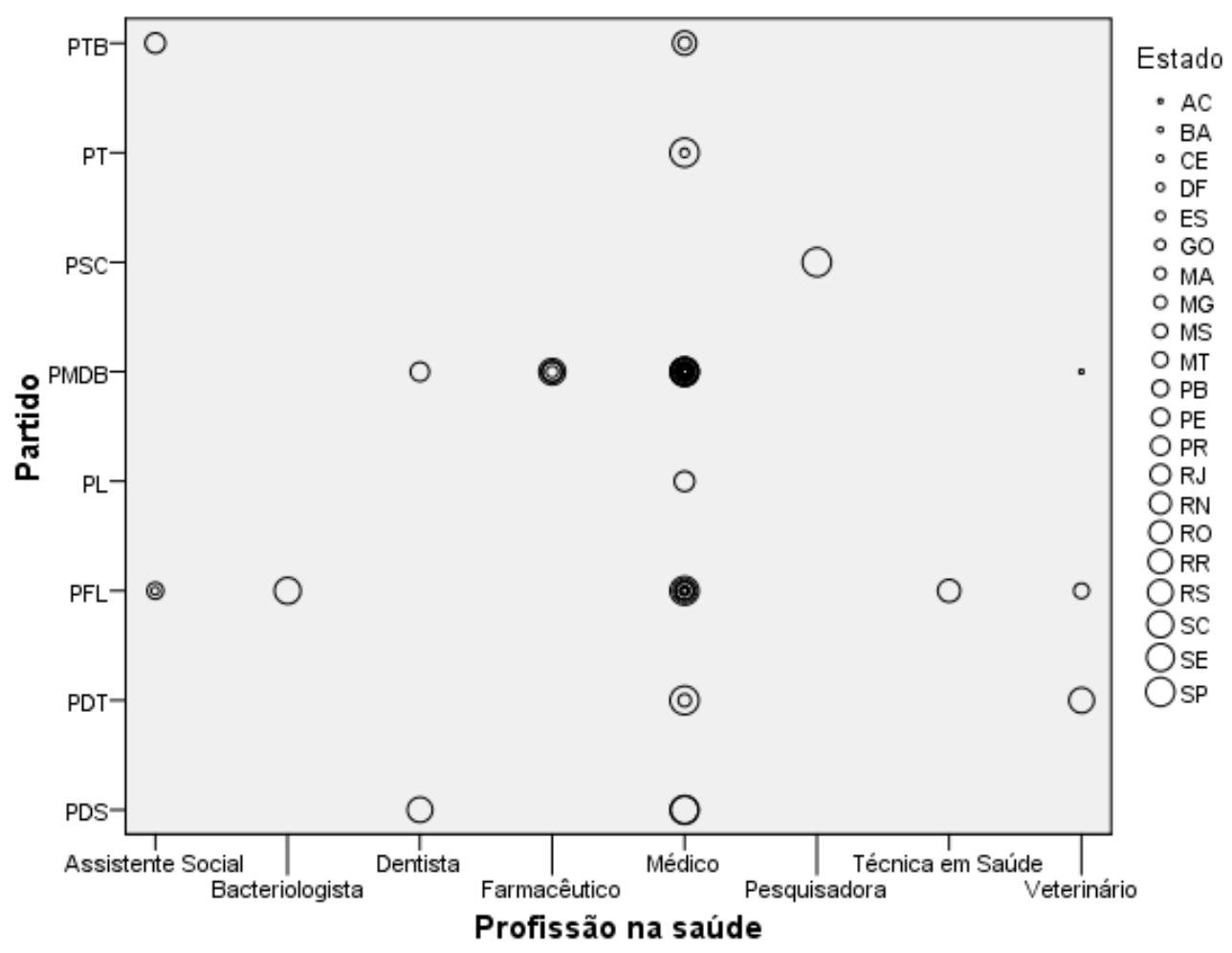

Em 1946, dentre os 338 constituintes, considerando-se titulares e suplentes, 297 deputados e 41 senadores, 56 (16,5\%) eram provenientes da área sanitária. Em 1987-88, dentre os 593 constituintes, considerando também titulares e suplentes, 512 deputados e 82 senadores, 68 (11\%) eram oriundos da saúde. Com uma pequena redução, os índices mantiveram-se entre $10 \mathrm{e}$ $20 \%$, considerando-se que em 1987-88 houve uma significativa mudança na formação universitária no Brasil, com uma larga ampliação dos cursos superiores e, consequentemente, o aumento da variedade de profissionais de áreas diferentes na ANC.

$\mathrm{Na}$ ANC de 1987-88, também, devemos considerar o alcance das classes populares às camadas de poder, o que também representou uma ampliação do leque de formação dos parlamentares - cursos técnicos, secundaristas etc. - posto a elitização do ensino superior no Brasil. As lutas sociais refletiram em uma mudança necessária no Parlamento. 
Considerando-se o avanço qualitativo da pauta sanitária no Brasil, não houve correlação com a incidência de novos agentes públicos provenientes das classes médicas, porém a atuação isolada de expoentes dos movimentos populares e da RSB representaram significativos avanços para a pauta. Eduardo Jorge, por exemplo, foi um dos grandes artífices da ANC 1987-88, ao propor mudanças significativas para o avanço das pautas sanitárias, trazendo inclusive conceitos nunca presentes no texto constitucional. Muitas dessas pautas foram resultantes da $8^{\mathrm{a}} \mathrm{CNS}$.

\section{O ANTEPROJETO}

Carlos Mosconi, deputado constituinte, foi o relator do Anteprojeto da Constituição Federal para a Subcomissão de Saúde, Seguridade e Meio Ambiente da Comissão da Ordem Social. Segundo o relatório do anteprojeto, foram ouvidas trinta e duas entidades "mais representativas do país" nas áreas de saúde, seguridade e meio ambiente. Totalizaram-se oito reuniões regimentais para elaboração do anteprojeto e, extraordinárias, mais sete.

"O elenco de Informações recebidas enriquecidas pelos debates aqui
realizados, permitem considerar que os membros dessa
Subcomissão foram suficientemente esclarecidos sobre as demandas
sociais referente aos temas abordados. Em acréscimo, houve a
oportunidade singular da realização de viagem de trabalho, quando
se visualizou mais de perto a realidade brasileira, mormente no que
tange ao meio ambiente" (MOSCONI, C. p.1).

4ª Reunião da Subcomissão de Saúde, Seguridade e Meio Ambiente.

A quarta reunião da Subcomissão de Saúde, Seguridade e Meio Ambiente ocorreu no dia 13 de abril de 1987, sob as seguintes pautas: I) discussão das entidades a serem convocadas para audiências públicas na Subcomissão; II) discussão do plano mínimo de trabalho. Outras pautas 
adjacentes: III) Visitas (delegações) às regiões do Pantanal, Angra dos Reis e Cubatão. Foram realizadas intervenções ${ }^{46}$ dos seguintes constituintes, sob a presidência de Fábio Feldman: Adylson Motta, Eduardo Moreira, Raimundo Bezerra, Eduardo Jorge, Jorge Uequed, Carlos Mosconi, Osvaldo Almeida, José Elias Murad e Maria de Lourdes Abadia.

Sr. Adylson Motta - intervenção: "que se visitasse também a zona carvoeira de Santa Catarina, alguma parte daquela região carbonífera".

Sr. Fábio Feldman (presidente interino) - intervenção: “(..) Plano de Trabalho, que determinou que haveria visita em três verificações no Pantanal, dias 25 e 26 de abril, sábado e domingo, e Angra dos Reis e Cubatão, dias 2 e 3 de maio.

(...) exatamente no dia 26 de abril faz um ano do acidente da usina de Chernobyl na União Soviética.

(...) a região lacustre de Cananéia e de Paranaguá e a região de Cubatão, porque ambas são regiões de mata atlântica, mata exuberante, e uma delas é praticamente intacta, a região estuarina lagunar de Cananéia, Iguape e Paranaguá, que se situa ao norte do Estado do Paraná e ao sul do Estado de São Paulo, e que tem sido objeto de uma grande depredação, através de uma ocupação absolutamente irracional e predatória.

Sr. Adylson Motta - intervenção (sobre a Usina de Candiota): "Porque temos lá $80 \%$ do carvão nacional. Só em Candiota há 20 bilhões de toneladas de carvão em reservas (...).

Sr. Raymundo Bezerra - intervenção:(..) aproveitando essas sugestões de viagens, para se visitar a periferia, talvez não de São Paulo, mas principalmente de uma Capital do Nordeste, Recife ou Fortaleza, porque sabemos que as condições de insalubridade, as condições de higiene, de saneamento, praticamente não existem e a interferência direta quanto à saúde da população é por demais importante".

Sr. Eduardo Jorge ${ }^{47}$ - intervenção: “(...) volto à questão da convocação da reunião com relação às entidades com as audiências públicas".

${ }^{46}$ No que tange aspectos concernentes à saúde, saúde ambiental, etc.

47 O Constituinte Eduardo Jorge foi convidado pelo presidente em exercício da reunião, Fábio Feldman, a compor a Mesa e auxiliar na condução dos trabalhos. 
Sr. Carlos Mosconi - intervenção: "(...) a sugestão que fiz para que também visitássemos duas áreas relacionadas com a saúde: uma região urbana e outra rural".

Sr. Osvaldo Almeida - intervenção: "Li aqui, na ata da última reunião, qualquer coisa que dizia respeito à Comissão Nacional da Reforma Sanitária, que, ao que me consta, é alguma coisa palpável que tem o Ministério da Saúde, onde eles falam também na Ceme, Central de Medicamentos".

Sr. Eduardo Jorge - intervenção: “(...) fiz um estudo do problema da Saúde. Vemos que essas quatro audiências aqui estão divididas em: 1) entidades estatais; 2) entidades patronais; 3) entidades de trabalhadores; 4) entidades científicas e éticas".

“(..) seja convidada a Comissão Nacional da Reforma Sanitária (...) o presidente do Conselho Nacional da Secretaria de Saúde do Estado e um representante do Conselho de Secretarias Municipais de Saúde. Aí teremos uma visão em três faixas - municipal, estadual e federal. Importante a Comissão de Reforma Sanitária, inclusive porque há representante dos vários Ministérios na área. Esta, a primeira audiência".

\section{(...)}

"Na segunda audiência - entidades patronais e prestadores de serviço -, arrolo aqui as seguintes entidades: a Sociedade de Medicina de Grupo, a Federação Brasileira de Hospitais, a Federação de Santas Casas de Misericórdia, a Representação da Federação das Cooperativas Médicas, e representantes de Confederações Patronais que tiverem interesse em comparecer".

\section{(...)}

"Na terceira audiência seriam ouvidas entidades da área científica e de ética. Então, convidaria os Conselhos, inclusive o Conselho Federal de Medicina, algumas associações Nacionais, como a ABEM, $A B M$, a Abrasco, uma associação que trata da questão do ensino da saúde coletiva, e a Associação Paulista de Saúde Pública (...)".

\section{5a Reunião da Subcomissão de Saúde, Seguridade e Meio Ambiente.}

A 5 ${ }^{\mathrm{a}}$ Reunião da Subcomissão de Saúde, Seguridade e Meio Ambiente ocorreu aos 14 dias do mês de abril de 1987, sob a presidência de constituinte José Elias Murad e contou com a presença dos seguintes membros: Luiz 
Soyer, Floriceno Paixão, Eduardo Jorge, Fábio Feldman, Maria de Lourdes Abadia, Oswaldo Almeida, Carlos Mosconi, Paulo Macarini e Raimundo Bezerra. Como ocorrido anteriormente, não houve quórum suficiente e a reunião foi conduzida sobre o formato de uma conversa informal, conforme ata publicada no DANC.

A pauta orbitou em torno do prazo para elaboração do anteprojeto pela Subcomissão, as áreas a serem visitadas, o estabelecimento de um calendário para as audiências e visitas, bem como, a elaboração de um plano e cronograma de trabalho a ser realizado no âmbito da Subcomissão. $\mathrm{Na}$ ocasião, foi informado que o presidente da ANC, Sr. Ulysses Guimarães, promoveria uma reunião a fim de viabilizar os recursos necessários às delegações da Subcomissão.

Durante as comunicações da reunião, o Sr. José Elias Murad, presidente da Subcomissão, destacou o expediente do Conselho Federal de Medicina, que solicitou participação em audiências. Através do presidente da Comissão da Ordem Social também foram apresentadas correspondência da Associação Brasileira de Pós-Graduação e Saúde Coletiva - Abrasco solicitando, também, participação e do Plenário dos Trabalhadores em Saúde Mental de São Paulo, que tratou da menção que o II Congresso de Trabalhadores de Saúde Mental do Estado de São Paulo sobre a discriminação da mulher, com propostas para carta constitucional. O presidente Murad destacou, ainda, que a Fundação Oswaldo Cruz encaminharia um documento pertinente à Reforma Sanitária. Seguem algumas intervenções sobre a questão sanitária:

Sr. Edme Tavares (presidente da Comissão da Ordem Social) intervenção: “(...) Várias regiões periféricas da marginalidade urbana em péssimas condições de saúde. Como a Favela do Paranoá, só conheço os Alagados da Bahia. Assim, proponho nesta parte da saúde, a visita da Comissão à Favela do Paranoá".

Sr. Raimundo Bezerra - intervenção: (...) Como não está nessa programação a possibilidade de ser visitado um Estado do Nordeste, principalmente da periferia, para que esta subcomissão, in loco, pudesse além de avaliar o estado deplorável da saúde, também uma participação de comunidades, de sindicatos, de áreas diretamente ligadas à saúde (...) incluindo uma visita a Salvador, ou a Fortaleza, 
ou a Recife, objetivando um conhecimento melhor dessas condições deploráveis de saúde".

Sra. Maria de Lourdes Abadia - intervenção: "Interessante visitar a periferia. Sugiro uma visita à Favela do Paranoá (...)".

\section{AUDIÊNCIAS PÚBLICAS.}

\section{1a Audiência Pública de 21 de abril de 1987.}

A 1a Audiência Pública, 6aㅡ reunião da Subcomissão, concentrou suas discussões na área da seguridade: "previdência privada" e "Sistema Único de Previdência Social de Planos e Benefícios”. Foram expositores: Amaury Soares Silveira (presidente da Associação Nacional da Previdência Privada - ANPP), João Reis Ricardo dos Santos (presidente da Superintendência de Seguros Privados - SUSESP) e Obed Dornelles Vargas (presidente da Confederação Brasileira de Aposentados e Pensionistas). Ressalva-se o recebimento de comunicações das entidades sanitárias:

Confederação das Misericórdias do Brasil (representando as Santas Casas de Misericórdia): "Solicitamos seu interesse sentido referendar relatório final VIII Conferência Nacional de saúde, que, pelo seu processo de elaboração e propostas nele contidos, possibilita a reversão do atual quadro sanitário do país".

Conselho Federal de Farmácia: "Os farmacêuticos brasileiros, integrantes do setor Saúde, representados pelo Conselho Federal de Farmácia, vêm, por meio deste, apresentarem,

\section{2ª Audiência Pública de 22 de abril de 1987.}

Durante a 2a Audiência Pública, 7aㅗ reunião da Subcomissão, os principais temas debatidos foram: "Sistema Nacional de Saúde", "Reforma Sanitária", "Sistema Unificado de Saúde" e "Ações Integradas de Saúde". Os expositores convidados foram: Laércio Moreira Valença (presidente do 
Conselho Nacional de Secretários de Saúde), Arlindo Fábio Gomes de Souza (Comissão Nacional da Reforma Sanitária), Roney Edmar Ribeiro (Conselho Nacional de Secretários de Saúde), Hésio Albuquerque Cordeiro (presidente do INAMPS), Roberto Chabo (presidente da Federação Nacional dos Médicos), José Luiz Riani Costa (Secretário de Segurança e Medicina do Trabalho - MT), Geraldo Justo (superintendente da Confederação das Misericórdias do Brasil), João José Cândido da Silva (coordenador da Assessoria de Saúde do MEC), Maria José dos Santos Rossi (presidente da Associação Brasileira de Enfermagem), Maria Luiza Jaeger (CUT), Cristina Albuquerque (Fiocruz), José Alberto Hermógenes de Souza (coordenador da Comissão Nacional de Reforma Sanitária) e Nelson Rodrigues dos Santos (representante do Conselho Nacional dos Secretários Municipais de Saúde).

\section{3a Audiência Pública de 22 de abril de 1987.}

A 3a Audiência Pública, 8aㅡ reunião da Subcomissão, tratou do tema da "política de previdência social", cujo único expositor foi Raphael de Almeida Magalhães (Ministro da Previdência e Assistência Social).

\section{4a Audiência Pública de 23 de abril de 1987.}

A 4⿳亠口冋 Audiência Pública, durante a 9a reunião da Subcomissão, versou sobre os seguintes temas: "desenvolvimento das sociedades humanas", "medicina de grupo", "estatização" e "privatização". Participaram os seguintes expositores: Silio Andrade (da Federação Nacional dos Hospitais), Alexandre Lourenço (da Associação Brasileira de Medicina de Grupo), Francisco Ubiratan Dellape (da Associação Nacional dos Estabelecimentos de Serviços de Saúde) e o Senador Albano Franco (da Confederação Nacional das Indústrias). 
5ª Audiência Pública de 28 de abril de 1987.

Durante a $5^{\mathrm{a}}$ Audiência Pública, $10^{\mathrm{a}}$ reunião da Subcomissão, foram abordados os seguintes temas: "Seguridade Social", "Questão da Saúde" e "Direito à Saúde". Participaram os seguintes expositores: Francisco dos Santos, Maria Luiza Jaeger (CUT), Sônia Republicano (do Sindicato dos Empregados de Estabelecimentos de Serviços de Saúde), Regina Senna (da Coordenação Nacional de Entidades Sindicais e Pré-sindicais de Enfermagem, CONESPSE), Roberto Chabo (da Federação Nacional dos Médicos) e Maria Aladilce de Souza (da Confederação Geral dos Trabalhadores - CGT).

\section{6a Audiência Pública de 29 de abril de 1987.}

A temática da 6⿳亠丷厂 Audiência Pública, 10 reunião da Subcomissão, foi: "reorganização do serviço de saúde"; "Sistema Único de Saúde"; "Direito à saúde"; "saúde"; "qualidade do alimento"; "laboratórios particulares"; "setor de análises clínicas", "vertente sócio sanitária", "vertente tecnológica industrial" e "Instituições filantrópicas". Tendo sido convidados os seguintes expositores: Moisés Goldbaum e Eleutério Rodrigues Neto (ambos da Associação Brasileira de Saúde Coletiva - Abrasco), Pedro Demitrov (da Associação Paulista de Saúde Pública), Célia Chaves, Renato Baruffaldi e Antônio Carlos Lyra (ambos do Conselho Federal de Farmácia), Francisco Álvaro Barbosa Costa (do Conselho Federal de Medicina), Marta Nóbrega Martinez (da Central de Medicamentos - Ceme), Nelson Proença (da Associação Médica Brasileira), Maria José dos Santos Rossi (da Associação Brasileira de Enfermagem), Arimar Ferreira Bastos(da Confederação das Misericórdias do Brasil), Ogari de Castro Pacheco (da Associação dos Laboratórios Farmacêuticos Nacionais Alanac), Hosana Garcez Moreira e Wolney Garrafa (ambos do Conselho Regional de Odontologia do Distrito Federal). 


\section{EMENDAS}

O artigo primeiro contou com grande quantidade de emendas a sua redação. No quadro abaixo estão separadas as iniciativas e cada fase da elaboração:

Tabela 18: Quadro de Emendas ao Artigo 1‥

\begin{tabular}{|c|c|c|}
\hline \multicolumn{3}{|c|}{ Quadro de Emendas ao Artigo $1^{\circ}$} \\
\hline Fase & Comissão & Número de Emendas \\
\hline $\mathrm{B}$ & Subcomissão da Nacionalidade, da Soberania e das Relações Internacionais & 16 \\
\hline $\mathrm{B}$ & Subcomissão dos Direitos Políticos, dos Direitos Coletivos e Garantias & 03 \\
\hline $\mathrm{B}$ & Subcomissão da União, Distrito Federal e Territórios & 08 \\
\hline $\mathrm{B}$ & Subcomissão dos Municípios e Regiões & 01 \\
\hline$E$ & Comissão da Soberania e dos Direitos e Garantias do Homem e da Mulher & 14 \\
\hline G & Comissão da Soberania e dos Direitos e Garantias do Homem e da Mulher & 05 \\
\hline $\mathrm{E}$ & Comissão de Organização do Estado & 16 \\
\hline $\mathrm{E}$ & Comissão de Organização do Estado & 17 \\
\hline JeK & Comissão de Sistematização & 27 \\
\hline M & Comissão de Sistematização & 137 \\
\hline $\mathrm{O}$ & Comissão de Sistematização & 83 \\
\hline$S$ & Plenário & 03 \\
\hline$U$ & Plenário & 04 \\
\hline w & Comissão de Redação & 10 \\
\hline
\end{tabular}

Conforme o parágrafo $4^{\circ}$ do artigo $59^{\circ}$ do Regimento Interno da Assembleia Nacional Constituinte, as emendas são as proposições apresentadas enquanto acessórias de outras, podendo ser classificadas em 
"supressiva", "aditiva", "substitutiva" ou "modificativa". Segundo o parágrafo $2^{\circ}$ do artigo $23^{\circ}$ foram vedadas as emendas que modificassem integralmente 0 projeto ou que tratem de mais de um dispositivo, excetuando-se as que tratam de modificações correlatas que inferiam no outro. As emendas foram elaboradas em formulário específico previsto no regimento e, obrigatoriamente, deveriam constar uma justificativa da proposição.

À Subcomissão de Saúde, Seguridade e Meio Ambiente da Comissão da Ordem Social foram apresentadas, na "FASE B", 152 emendas ao Anteprojeto, elaborado pelo relator Dep. Carlos Mosconi. Dessas, 49 (32\%) eram concernentes a temas ligados à saúde exclusivamente ou a este estavam correlacionadas. Nos quadros a seguir é possível identificar a prevalência de duas temáticas. A pauta da saúde privada aparece em 19 (38,7\%) das 49 propostas de emendas apresentadas pelos constituintes ao anteprojeto. $O$ segundo tema com maior incidência de emendas é a questão dos medicamentos, presente em 13 (26,5\%) propostas.

O tema da saúde privada aparece, em linhas gerais, atrelado a três grandes questionamentos: I) a livre iniciativa - ou seja, a permissão constitucional da atuação privada no setor; II) a desapropriação ou expropriação dos serviços privados de saúde e, por fim: III) a saúde privada enquanto suplementar, em caráter colaborativo. A atuação da saúde privada foi objetivo de emendas de alguns constituintes que fizeram proposições apenas nesta área, em detrimento aos outros debates sanitários. Citamos os constituintes: Cunha Bueno (PDS), Ruy Nedel (PMDB), José Agripino (PFL), Abigail Feitosa (PMDB), Rose de Freitas (PMDB), cuja matéria foi tratada em todas as suas proposições e - não exclusivamente, porém com grande incidência - em Bosco França (PMDB) e Domingos Leonelli (PMDB).

O tema dos medicamentos - segundo maior item presente nas emendas apresentadas - é tratado sobre a perspectiva dos modos de organização e distribuição, bem como, quanto à automedicação e sua veiculação nas propagandas comerciais. Frequentemente, a matéria aparece atrelada ao tabaco e outras drogas como as bebidas alcoólicas. Houve, ainda, a contribuição do Dep. Mário Maia (PDT) que através da Emenda 7B0031-5 
tratou da obrigatoriedade do Poder Público em assegurar um Plano de Atenção Básica de Saúde e Assistência Farmacêutica.

Tabela 19: Quadro de Temas das Emendas ao Anteprojeto na "FASE B"

\begin{tabular}{|c|c|c|}
\hline \multicolumn{3}{|c|}{ Quadro de Temas das Emendas ao Anteprojeto na "FASE B" } \\
\hline Tema Central & Subtemas e Proponentes & Ocorrências \\
\hline Órgãos & $\begin{array}{l}\text { - Comercialização de Órgãos (Eduardo Jorge) } \\
\text { - Transplantes de órgãos (Jofran Frejat) } \\
\text { - Doação de Órgãos (Sadie Hauache) } \\
\text { - Doação de Órgãos (Meira Filho) }\end{array}$ & 04 \\
\hline $\begin{array}{l}\text { Medicamentos } \\
\text { e Drogas }\end{array}$ & $\begin{array}{l}\text { - Organização e distribuição de medicamentos (Eduardo Jorge) } \\
\text { - Controle de Drogas e substâncias tóxicas (José Elias Murad) } \\
\text { - Propaganda comercial de medicamentos (José Elias Murad) } \\
\text { - Assistência farmacêutica (Mario Maia) } \\
\text { - Políticas públicas de medicamentos (Nilson Gibson) } \\
\text { - Automedicação (Nilson Gibson) } \\
\text { - Consumo de bebidas alcoólicas e tabaco (Homero Santos) } \\
\text { - Consumo de bebidas alcoólicas e tabaco (Borges da Silveira) } \\
\text { - Produção de medicamentos e outros (Borges da Silveira) } \\
\text { - Propaganda de medicamentos e tabacos (Borges da Silveira) } \\
\text { - Propaganda de medicamentos, tabacos e outros (Heráclito Fortes) } \\
\text { - Importação de insumos para medicamentos (Walmor de Luca) } \\
\text { - Propaganda de Medicamentos, tabacos e bebidas alcoólicas (Raimundo } \\
\text { Rezende) }\end{array}$ & 13 \\
\hline $\begin{array}{l}\text { Saúde do } \\
\text { Trabalhador }\end{array}$ & $\begin{array}{l}\text { - Proteção, Segurança e Higiene no Trabalho (Eduardo Jorge) } \\
\text { - Trabalho insalubre (Eduardo Jorge) } \\
\text { - Auxílio doença. (Eduardo Jorge) } \\
\text { - Seguridade do Trabalhador Insalubre (Eduardo Jorge) }\end{array}$ & 04 \\
\hline Dignidade & $\begin{array}{l}\text { - Reabilitação da Saúde e condições dignas de vida (Eduardo Jorge) } \\
\text { - Saúde como dever do Estado, sem qualquer discriminação (Felipe Mendes) }\end{array}$ & 02 \\
\hline Direito à Saúde & $\begin{array}{l}\text { - Direito à saúde (Eduardo Jorge) } \\
\text { - Direito à Saúde (Borges da Silveira) } \\
\text { - Direito à assistência integral à saúde (Moema São Thiago) }\end{array}$ & 03 \\
\hline Alimentação & $\begin{array}{l}\text { - Segurança Alimentar (Eduardo Jorge) } \\
\text { - Qualidade dos alimentos, medicamentos e outros (José Elias Murad) }\end{array}$ & 02 \\
\hline Eutanásia & - Eutanásia (Eduardo Jorge) & 01 \\
\hline Poder Público & $\begin{array}{l}\text { - Deveres do Poder Público (Eduardo Jorge) } \\
\text { - Promoção da Saúde (Jofran Frejat) } \\
\text { - Recursos financeiros à saúde (Borges da Silveira) } \\
\text { - Dever do Estado (Felipe Mendes) } \\
\text { - Diretrizes da Saúde, enquanto dever do Estado (Paulo Macarini) }\end{array}$ & 05 \\
\hline $\begin{array}{l}\text { Instituições } \\
\text { sem fins }\end{array}$ & $\begin{array}{l}\text { - Instituições Filantrópicas (Geraldo Alckmin) } \\
\text { - Veda os fins lucrativos na saúde aos prestadores de serviço público (Eduardo }\end{array}$ & 02 \\
\hline
\end{tabular}




\begin{tabular}{|c|c|c|}
\hline lucrativos & Jorge) & \\
\hline Saúde Privada & $\begin{array}{l}\text { - Livre iniciativa na saúde (Cunha Bueno) }{ }^{48} \\
\text { - Livre iniciativa na saúde (Cunha Bueno) } \\
\text { - Livre iniciativa na saúde (Cunha Bueno) } \\
\text { - Saúde Complementar (Jofran Frejat) } \\
\text { - Livre exercício profissional da saúde (Jofran Frejat) } \\
\text { - Serviços privados de saúde (Ruy Nedel) } \\
\text { - Atuação mediante contrato de Direito Público (Anna Maria Rattes) } \\
\text { - Saúde Suplementar (Abigail Feitosa) } \\
\text { - Livre iniciativa na Saúde (Rose de Freitas) } \\
\text { - Desapropriação de serviços de saúde privados (Bosco França) } \\
\text { - Serviços Privados de Saúde e incentivos fiscais (Bosco França) } \\
\text { - Direito à Saúde e a Livre Iniciativa Privada (Bosco França) } \\
\text { - Direito à Saúde e a Livre Iniciativa Privada (Bosco França) } \\
\text { - Serviços públicos e excepcionalmente privados (Domingos Leonelli) } \\
\text { - Desapropriação ou expropriação de serviços de saúde privados (Raimundo } \\
\text { Rezende) } \\
\text { - Desapropriação ou expropriação de serviços de saúde privados, mediante } \\
\text { indenização (Borges da Silveira) } \\
\text { - Desapropriação ou expropriação de serviços de saúde privados (Borges da } \\
\text { Silveira) } \\
\text { - Desapropriação ou expropriação de serviços de saúde privados (Felipe } \\
\text { Mendes) } \\
\text { - Desapropriação ou expropriação de serviços de saúde privados (Jose } \\
\text { Agripino) }\end{array}$ & 19 \\
\hline $\begin{array}{l}\text { Sistema de } \\
\text { Saúde }\end{array}$ & $\begin{array}{l}\text { - Sistema Único (Nilson Gibson) } \\
\text { - Plano Nacional de Desenvolvimento da Saúde (Cesar Carls Neto) } \\
\text { - Organização da saúde (Moema São Thiago) } \\
\text { - Saúde coletiva e individual (Felipe Mendes) } \\
\text { - Sistema Único de Saúde (Felipe Mendes) } \\
\text { - Municipalização da Saúde (Jorge Vianna) } \\
\text { - Diretrizes da Saúde (Bosco França) } \\
\text { - Trata do acesso, financiamento e outros (Jitahy Magalhães) }\end{array}$ & 08 \\
\hline $\begin{array}{c}\text { Assistência } \\
\text { Multiprofission } \\
\text { al }\end{array}$ & - Assistência Terapêutica Multiprofissional (Moema São Thiago) & 01 \\
\hline Negligência & - Crime na área da saúde (Mauricio Nasser) & 01 \\
\hline Experimentos & - Uso de cobaias (Mauricio Nasser) & 01 \\
\hline $\begin{array}{l}\text { Primeiros } \\
\text { Socorros }\end{array}$ & - Atendimento de gravidade (Eliel Rodrigues) & 01 \\
\hline
\end{tabular}

${ }^{48}$ As emendas 7B0012-9, 7B0013-7 e 7B0014-5 possuem o mesmo teor. 


\begin{tabular}{clc}
\hline $\begin{array}{c}\text { Medicina } \\
\text { Informal }\end{array}$ & - Assegura o exercício da medicina informal (Flavio Pamier da Veiga) & 01 \\
\hline $\begin{array}{c}\text { Saúde da } \\
\text { Mulher }\end{array}$ & - Assistência integral à saúde da mulher (Anna Maria Rattes) & 01 \\
\hline Danos à Saúde & - Controle da produção de substâncias nocivas à saúde (Mendes Thame) & 01 \\
\hline $\begin{array}{c}\text { Financiamento } \\
\text { da Saúde }\end{array}$ & - Recursos à Saúde (Luiz Alfredo Salomão) & 02 \\
\hline Natalidade & - Direito à livre natalidade (Luiz Alfredo Salomão) & 01 \\
\hline
\end{tabular}

No quadro a seguir, apresentamos as emendas propostas na área da saúde em relação ao total de emendas na 'Fase B'. Observa-se a quantidade de proposições realizadas por Eduardo Jorge, que apresentou $1 / 4$ dos projetos de saúde na ANC 1987-88:

Tabela 20: Quadro de Emendas ao Anteprojeto - FASE B

\begin{tabular}{|c|c|c|c|c|}
\hline \multicolumn{5}{|c|}{ Quadro de Emendas ao Anteprojeto - "FASE B" } \\
\hline Constituinte & Profissão & $\begin{array}{c}\text { Número } \\
\text { de } \\
\text { Emendas }\end{array}$ & $\begin{array}{l}\text { Percentual } \\
\text { na Saúde }\end{array}$ & $\begin{array}{l}\text { Percentual } \\
\text { Total }\end{array}$ \\
\hline Abigail Feitosa & Médica & 02 & $4 \%$ & $1,3 \%$ \\
\hline Ademar de Barros & Industrial / Químico & 01 & $2 \%$ & $0,65 \%$ \\
\hline Adylson Motta & Dentista / Advogado & 01 & $2 \%$ & $0,65 \%$ \\
\hline Alarico Abib & Médico / Agropecuarista & 03 & $6 \%$ & $2 \%$ \\
\hline Anna Maria Rattes & Advogada & 03 & $6 \%$ & $2 \%$ \\
\hline Antero de Barros & Jornalista / Radialista & 01 & $2 \%$ & $0,65 \%$ \\
\hline Brandão Monteiro & Advogado / Bancário & 03 & $6 \%$ & $2 \%$ \\
\hline Borges da Silveira & $\begin{array}{c}\text { Médico / } \\
\text { Agropecuarista }\end{array}$ & 07 & $14,3 \%$ & $4,6 \%$ \\
\hline Bosco França & Médico / Empresário & 05 & $10,2 \%$ & $3,3 \%$ \\
\hline Célio de Castro & Médioa / Professor & 07 & $14,3 \%$ & $4,6 \%$ \\
\hline Cesar Carls Neto & Economista & 01 & $2 \%$ & $0,65 \%$ \\
\hline Cunha Bueno & $\begin{array}{c}\text { Economista / Corretor } \\
\text { de Seguros }\end{array}$ & 03 & $6 \%$ & $2 \%$ \\
\hline Domingos Leonelli & Publicitário & 01 & $2 \%$ & $0,65 \%$ \\
\hline Doreto Campanari & Médico & 01 & $2 \%$ & $0,65 \%$ \\
\hline Eduardo Jorge & Médico & 17 & $24,5 \%$ & $7,9 \%$ \\
\hline Eduardo Moreira & Médico & 02 & $4 \%$ & $1,3 \%$ \\
\hline Eliel Rodrigues & Engenheiro & 01 & $2 \%$ & $0,65 \%$ \\
\hline Eliezer Moreira Filho & $\begin{array}{l}\text { Advogado / Serv. } \\
\text { Público }\end{array}$ & 01 & $2 \%$ & $0,65 \%$ \\
\hline Felipe Mendes & Economista & 05 & $10,2 \%$ & $3,3 \%$ \\
\hline França Teixeira & Advogado / Empresário & 01 & $2 \%$ & $0,65 \%$ \\
\hline
\end{tabular}




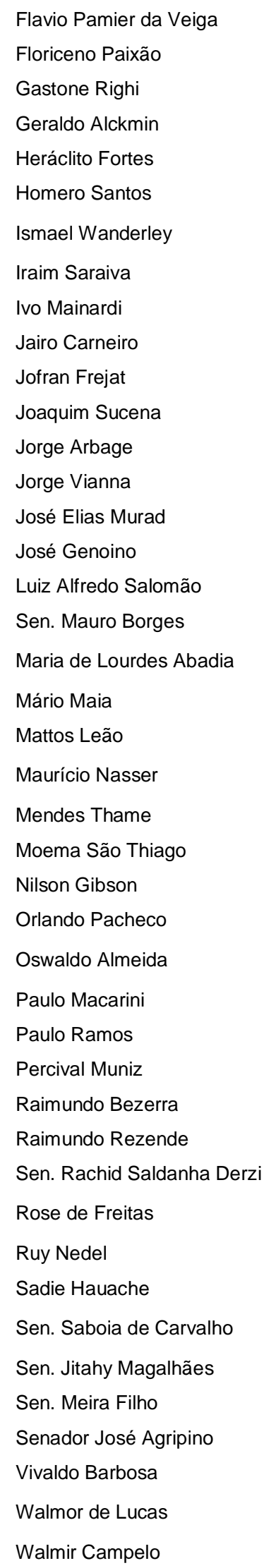

\begin{tabular}{|c|c|c|c|}
\hline Advogado / Professor & 01 & $2 \%$ & $0,65 \%$ \\
\hline Advogado / Editor & 02 & $4 \%$ & $1,3 \%$ \\
\hline Advogado / Professor & 01 & $2 \%$ & $0,65 \%$ \\
\hline Médico & 02 & $2 \%$ & $0,65 \%$ \\
\hline Advogado & 01 & $2 \%$ & $0,65 \%$ \\
\hline Advogado & 01 & $2 \%$ & $0,65 \%$ \\
\hline $\begin{array}{l}\text { Advogado / } \\
\text { Administrador }\end{array}$ & 02 & $4 \%$ & $1,3 \%$ \\
\hline Advogado & 01 & $2 \%$ & $0,65 \%$ \\
\hline Advogado & 01 & $2 \%$ & $0,65 \%$ \\
\hline Advogado & 01 & $2 \%$ & $0,65 \%$ \\
\hline Médico & 04 & $8 \%$ & $2,6 \%$ \\
\hline Médico & 03 & $6 \%$ & $2 \%$ \\
\hline Advogado & 01 & $2 \%$ & $0,65 \%$ \\
\hline Médico e Agricultor & 01 & $2 \%$ & $0,65 \%$ \\
\hline Médico & 04 & $6 \%$ & $2 \%$ \\
\hline Professor & 01 & $2 \%$ & $0,65 \%$ \\
\hline Economista & 03 & $6 \%$ & $2 \%$ \\
\hline Militar & 01 & $2 \%$ & $0,65 \%$ \\
\hline $\begin{array}{c}\text { Professora / Assistente } \\
\text { Social }\end{array}$ & 03 & $6 \%$ & $2 \%$ \\
\hline Advogado & 01 & $2 \%$ & $0,65 \%$ \\
\hline Médico / Agropecuarista & 02 & $4 \%$ & $1,3 \%$ \\
\hline $\begin{array}{l}\text { Administrador de } \\
\text { Empresas }\end{array}$ & 02 & $4 \%$ & $1,3 \%$ \\
\hline Advogado e Agrônomo & 01 & $2 \%$ & $0,65 \%$ \\
\hline Advogada & 03 & $6 \%$ & $2 \%$ \\
\hline Advogado / Economista & 03 & $6 \%$ & $2 \%$ \\
\hline Professor Teologia & 01 & $2 \%$ & $0,65 \%$ \\
\hline $\begin{array}{l}\text { Agricultor / Economista / } \\
\text { Militar }\end{array}$ & 07 & $14,3 \%$ & $4,6 \%$ \\
\hline Advogado & 01 & $2 \%$ & $0,65 \%$ \\
\hline Advogado / Militar & 03 & $6 \%$ & $2 \%$ \\
\hline Agricultor / Topógrafo & 01 & $2 \%$ & $0,65 \%$ \\
\hline Médico & 01 & $2 \%$ & $0,65 \%$ \\
\hline Médico & 02 & $4 \%$ & $1,3 \%$ \\
\hline Médico / Agropecuarista & 01 & $2 \%$ & $0,65 \%$ \\
\hline $\begin{array}{l}\text { Jornalista, Professora e } \\
\text { Produtora Rural }\end{array}$ & 01 & $2 \%$ & $0,65 \%$ \\
\hline Médico & 01 & $2 \%$ & $0,65 \%$ \\
\hline Jornalista e Empresária & 01 & $2 \%$ & $0,65 \%$ \\
\hline $\begin{array}{c}\text { Advogado / Professor / } \\
\text { Radialista }\end{array}$ & 01 & $2 \%$ & $0,65 \%$ \\
\hline Administrador Público & 04 & $6 \%$ & $2 \%$ \\
\hline Advogado & 01 & $2 \%$ & $0,65 \%$ \\
\hline Advogado & 01 & $2 \%$ & $0,65 \%$ \\
\hline Advogado / Professor & 01 & $2 \%$ & $0,65 \%$ \\
\hline $\begin{array}{l}\text { Farmacêutico- } \\
\text { Bioquímico }\end{array}$ & 01 & $2 \%$ & $0,65 \%$ \\
\hline Comunicador Social & 01 & $2 \%$ & $0,65 \%$ \\
\hline
\end{tabular}


As propostas de Eduardo Jorge (PT) em sua maioria foram inovadoras no conteúdo e na concepção. O constituinte abordou temas polêmicos e de interesse nacional, apresentou temas relacionados à saúde do trabalhador e, até mesmo, à comercialização de órgãos no Brasil. A maioria das pautas apresentadas pelo constituinte foram debatidas na $8^{\underline{a}} \mathrm{CNS}$ :

\begin{tabular}{|c|c|c|c|}
\hline \multicolumn{4}{|c|}{ Emendas - Constituinte: EDUARDO JORGE (PT) } \\
\hline Número & Artigo & Área & Síntese \\
\hline $\begin{array}{l}7 B 0001-3 \\
(14 / 05 / 87)\end{array}$ & $8^{\circ} \S 3^{\circ}$ & Comercialização de Órgãos. & $\begin{array}{l}\text { Proibição da comercialização de órgãos, } \\
\text { elementos e tecidos. }\end{array}$ \\
\hline $\begin{array}{l}\text { 7B0002-1 } \\
(14 / 05 / 87)\end{array}$ & $5^{\circ} \S$ único & Medicamentos. & $\begin{array}{l}\text { Estabelecer a obrigação estatal na organização } \\
\text { e distribuição de medicamentos e outros. }\end{array}$ \\
\hline $\begin{array}{l}7 \mathrm{~B} 0003-0 \\
(14 / 05 / 87)\end{array}$ & $6^{\circ} \S 1^{\circ}$ e $2^{\circ}$ & $\begin{array}{l}\text { Proteção, segurança e higiene } \\
\text { do trabalho. }\end{array}$ & $\begin{array}{l}\text { Fiscalizar e controlar as condições dos } \\
\text { equipamentos, dos ambientes e da organização } \\
\text { do trabalho. }\end{array}$ \\
\hline $\begin{array}{l}\text { 7B0004-8 } \\
(14 / 05 / 87)\end{array}$ & $1^{\circ}$ e $2^{\circ}$ & $\begin{array}{l}\text { Condição digna de vida e } \\
\text { direitos. }\end{array}$ & $\begin{array}{l}\text { Garantir os direitos da parcela da população que } \\
\text { socialmente e tradicionalmente está muito ligada } \\
\text { à questão saúde. }\end{array}$ \\
\hline $\begin{array}{l}\text { 7B0007-2 } \\
(14 / 05 / 87)\end{array}$ & $\begin{array}{l}\text { Onde } \\
\text { couber }\end{array}$ & Nutrição e Segurança alimentar. & $\begin{array}{l}\text { Cria o subsistema de Nutrição e Segurança } \\
\text { Alimentar. }\end{array}$ \\
\hline $\begin{array}{l}\text { 7B0017-0 } \\
(15 / 05 / 87)\end{array}$ & $10^{\circ}$ & Eutanásia. & $\begin{array}{l}\text { Visa suprimir o artigo para posterior debate e } \\
\text { diferenciar eutanásia passiva, ativa, voluntária e } \\
\text { involuntária. }\end{array}$ \\
\hline $\begin{array}{l}\text { 7B0019-6 } \\
(15 / 05 / 87)\end{array}$ & $1^{\circ} \S$ único & Reabilitação da Saúde. & $\begin{array}{l}\text { Garantir condições dignas de vida e acesso } \\
\text { igualitário à promoção, proteção, recuperação e } \\
\text { reabilitação da saúde. }\end{array}$ \\
\hline $\begin{array}{l}7 \mathrm{~B} 0020-0 \\
(15 / 05 / 87)\end{array}$ & $2^{o}$ & Poder Público e a Saúde. & $\begin{array}{l}\text { Estabelece deveres ao Poder Público na } \\
\text { promoção da Saúde. }\end{array}$ \\
\hline $\begin{array}{l}7 B 0021-8 \\
(15 / 05 / 87)\end{array}$ & $4^{\circ} \S 1^{0}$ & $\begin{array}{l}\text { Instituições de Saúde sem fins } \\
\text { lucrativos. }\end{array}$ & $\begin{array}{l}\text { Veda a prestação de serviços com fins lucrativos } \\
\text { às concessionárias, que prestem serviços } \\
\text { públicos de saúde. }\end{array}$ \\
\hline $\begin{array}{l}\text { 7B0105-2 } \\
(18 / 05 / 87)\end{array}$ & $6^{\circ} \S 1^{\circ}$ e $2^{\circ}$ & Trabalho Insalubre. & $\begin{array}{l}\text { Utilização de medidas tecnológicas para eliminar } \\
\text { as condições de trabalho insalubre. }\end{array}$ \\
\hline $\begin{array}{l}\text { 7B0106-1 } \\
(18 / 05 / 87)\end{array}$ & $2^{\circ}$ e $4^{\circ}$ & Auxílio Doença. & $\begin{array}{l}\text { Estabelece direito à seguridade devido acidente, } \\
\text { doença, tempo de serviço, velhice, licença } \\
\text { médica e outros. }\end{array}$ \\
\hline $\begin{array}{l}\text { 7B0107-9 } \\
(18 / 05 / 87)\end{array}$ & $5^{\circ}$ & $\begin{array}{l}\text { Seguridade ao Trabalhador em } \\
\text { condições insalubres. }\end{array}$ & $\begin{array}{l}\text { Garante direito à seguridade aos trabalhadores } \\
\text { em condições insalubres entre outros. }\end{array}$ \\
\hline $\begin{array}{l}\text { 7B0154-1 } \\
(19 / 05 / 87)\end{array}$ & $\mathrm{NI}$ & Saúde da Mulher e natalidade. & $\begin{array}{l}\text { Prevê assistência integral à saúde da mulher e } \\
\text { livre natalidade. }\end{array}$ \\
\hline $\begin{array}{l}\text { 7B0193-1 } \\
(19 / 05 / 87)\end{array}$ & $5^{\circ} \S 2^{\circ}$ & Sistema Único de Saúde & $\begin{array}{l}\text { Visa a política de recursos humanos no SUS, } \\
\text { com plano de carreira, isonomia de salários e } \\
\text { outros. }\end{array}$ \\
\hline
\end{tabular}




\begin{tabular}{|c|c|c|c|}
\hline $\begin{array}{l}\text { 7B0294-6 } \\
(19 / 05 / 87)\end{array}$ & $\begin{array}{l}\text { Onde } \\
\text { couber }\end{array}$ & Acidente de Trabalho & $\begin{array}{l}\text { Estabelece o Seguro de Acidente de Trabalho, } \\
\text { ao trabalhador vitimado por doença ocupacional. }\end{array}$ \\
\hline $\begin{array}{l}7 B 0295-4 \\
(19 / 05 / 87)\end{array}$ & $\begin{array}{l}\text { Onde } \\
\text { couber }\end{array}$ & Acidentes de Trânsito & $\begin{array}{l}\text { Estabelece o Seguro à vítima de acidente de } \\
\text { trânsito. }\end{array}$ \\
\hline $\begin{array}{l}\text { 7B0296-2 } \\
(19 / 05 / 87)\end{array}$ & $\begin{array}{c}4^{\circ} \text { } \S 1^{\circ} 0 \\
\text { Disposições } \\
\text { Transitórias. }\end{array}$ & Serviços Privados de Saúde. & $\begin{array}{l}\text { Suprimi o artigo que trata dos serviços privados } \\
\text { de saúde em colaboração à cobertura } \\
\text { assistência, por tratar de mesmo tema nas } \\
\text { disposições transitórias. E dá redação às } \\
\text { disposições transitórias. Limita em } 10 \text { anos o } \\
\text { prazo máximo para transferência de recursos à } \\
\text { iniciativa privada. Estabelece que o serviço } \\
\text { complementar reger-se-á por contrato de direito } \\
\text { público, estando vedada a participação de } \\
\text { empresa com finalidade lucrativa. }\end{array}$ \\
\hline
\end{tabular}

Raimundo Rezende (PMDB) apresentou 2 propostas de emenda ao projeto da Constituição de 88 , versando sobre medicamento e o recorrente tema dos serviços privados de saúde no Brasil:

\begin{tabular}{|c|c|c|c|}
\hline \multicolumn{4}{|c|}{ Emendas - Constituinte: RAIMUNDO REZENDE (PMDB) } \\
\hline Número & Artigo & Área & Síntese \\
\hline $\begin{array}{l}\text { 7B0005-6 } \\
(14 / 05 / 87)\end{array}$ & $7^{0}$ & $\begin{array}{l}\text { Propaganda de medicamentos, } \\
\text { tabacos e bebidas alcoólicas. }\end{array}$ & $\begin{array}{l}\text { Aprimorar o texto considerando a necessidade } \\
\text { de não impedir a divulgação cientifica junto aos } \\
\text { profissionais de saúde. }\end{array}$ \\
\hline $\begin{array}{l}\text { 7B0006-4 } \\
(14 / 05 / 87)\end{array}$ & $4^{\circ} \S 2^{\circ}$ & $\begin{array}{l}\text { Desapropriação ou expropriação } \\
\text { de serviços de saúde privados. }\end{array}$ & $\begin{array}{l}\text { Desapropriação ou expropriação dos serviços } \\
\text { de saúde privados pelo poder público } \\
\text { necessários ao alcance dos objetivos da política } \\
\text { nacional do setor. }\end{array}$ \\
\hline
\end{tabular}

José Elias Murad (PTB) dedicou-se à questão dos medicamentos, alimentos e das drogas. Além disso, buscou garantir condições dignas de vida e acesso igualitário aos serviços de saúde:

\begin{tabular}{|c|c|c|c|}
\hline \multicolumn{4}{|c|}{ Emendas - Constituinte: JOSÉ ELIAS MURAD (PTB) } \\
\hline Número & Artigo & Área & Síntese \\
\hline $\begin{array}{l}\text { 7B0008-1 } \\
(14 / 05 / 87)\end{array}$ & $5^{\circ} \S 2^{\circ}$ & $\begin{array}{l}\text { Controle de Drogas e } \\
\text { Substâncias Tóxicas. }\end{array}$ & $\begin{array}{l}\text { Estado exercer o controle das drogas de abuso } \\
\text { e demais produtos tóxicos inebriantes e } \\
\text { estabelecer princípios básicos para a prevenção } \\
\text { de seu uso. }\end{array}$ \\
\hline $\begin{array}{l}7 B 0010-2 \\
(14 / 05 / 87)\end{array}$ & 90 & $\begin{array}{l}\text { Qualidade dos Alimentos, } \\
\text { Medicamentos e outros. }\end{array}$ & $\begin{array}{l}\text { Fiscalização da qualidade dos alimentos, } \\
\text { medicamentos e outros produtos de consumo e } \\
\text { uso humano. }\end{array}$ \\
\hline
\end{tabular}




\begin{tabular}{|c|c|c|c|}
\hline $\begin{array}{l}\text { 7B0011-1 } \\
(14 / 05 / 87)\end{array}$ & $7^{0}$ & $\begin{array}{l}\text { Propaganda Comercial de } \\
\text { Medicamentos. }\end{array}$ & $\begin{array}{l}\text { Veda a propaganda comercial de } \\
\text { medicamentos, formas de tratamento, tabaco e } \\
\text { bebidas alcoólicas. }\end{array}$ \\
\hline $\begin{array}{l}\text { 7B0156-7 } \\
(19 / 05 / 87)\end{array}$ & & $\begin{array}{l}\text { Condições dignas e acesso } \\
\text { igualitário. }\end{array}$ & $\begin{array}{l}\text { Prevê condições dignas de vida e acesso } \\
\text { igualitário nos serviços de saúde; }\end{array}$ \\
\hline
\end{tabular}

Cunha Bueno (PDS) dedicou-se exclusivamente, nas emendas, à atividade médico-hospitalar independente do sistema de saúde, a livre iniciativa:

\begin{tabular}{|c|c|c|c|}
\hline \multicolumn{4}{|c|}{ Emendas - Constituinte: CUNHA BUENO (PDS) } \\
\hline Número & Artigo & Área & Síntese \\
\hline $\begin{array}{l}\text { 7B0012-9 } \\
(14 / 05 / 87)\end{array}$ & $2^{\circ}$ e $4^{\circ}$ & Livre Iniciativa na Saúde & $\begin{array}{l}\text { O sistema único não excluirá o desenvolvimento } \\
\text { da atividade médico-hospitalar liberal. }\end{array}$ \\
\hline $\begin{array}{l}\text { 7B0013-7 } \\
(14 / 05 / 87)\end{array}$ & $2^{\circ}$ e $4^{\circ}$ & $\begin{array}{l}\text { Mesmo teor da Emenda } \\
\text { 7B0012949 }\end{array}$ & Mesmo teor da Emenda 7B0012-9 \\
\hline $\begin{array}{l}\text { 7B0014-5 } \\
(14 / 05 / 87)\end{array}$ & $2^{\circ}$ e $4^{\circ}$ & Mesmo teor da Emenda 7B00129 & Mesmo teor da Emenda 7B0012-9 \\
\hline
\end{tabular}

Jofran Frejat (PFL) destacou temas em alta na ANC, como o livre exercício profissional da saúde e a saúde complementar. Porém, inovou em abordar a questão do transplante de órgãos:

\begin{tabular}{|c|c|c|c|}
\hline \multicolumn{4}{|c|}{ Emendas - Constituinte: JOFRAN FREJAT (PFL) } \\
\hline Número & Artigo & Área & Síntese \\
\hline $\begin{array}{l}\text { 7B0023-4 } \\
(16 / 05 / 87)\end{array}$ & $1^{\circ}$ & Promoção da Saúde. & $\begin{array}{l}\text { Obriga o Poder Público a prevenir doenças } \\
\text { promover a saúde. }\end{array}$ \\
\hline $\begin{array}{l}\text { 7B0025-1 } \\
(16 / 05 / 87)\end{array}$ & $8^{\circ}$ & Transplante de Órgãos. & Prevê o transplante de órgãos e tecidos. \\
\hline $\begin{array}{l}7 \mathrm{~B} 0026-9 \\
(16 / 05 / 87)\end{array}$ & $4^{0}$ & Saúde Complementar. & $\begin{array}{l}\text { Trata da competência decisória sobre a atuação } \\
\text { da saúde privada em complementaridade à } \\
\text { pública. }\end{array}$ \\
\hline $\begin{array}{l}\text { 7B0027-7 } \\
(16 / 05 / 87)\end{array}$ & $4^{\circ} \S 2^{\circ}$ & $\begin{array}{l}\text { Livre exercício profissional na } \\
\text { Saúde e Saúde privada. }\end{array}$ & $\begin{array}{l}\text { Assegura o livre exercício profissional na saúde } \\
\text { e a organização de serviços privados de Saúde. }\end{array}$ \\
\hline
\end{tabular}

${ }^{49}$ As emendas 7B0013-7 e 7B0014-5 abordam o mesmo conteúdo, contendo, porém alterações de vocábulo e justificativa. 
Ruy Nedel (PMDB) apresentou apenas uma sugestão ao projeto, que versou sobre a atuação do setor privado de saúde:

\begin{tabular}{cccc}
\hline \multicolumn{5}{c}{ Emendas - Constituinte: RUY NEDEL (PMDB) } \\
\hline Número & Artigo & Área & Síntese \\
\hline $\begin{array}{c}\text { 7B0024-2 } \\
(16 / 05 / 87)\end{array}$ & $4^{\circ} \S 1^{\circ}$ a $3^{\circ}$ & Serviços Privados de Saúde. & Prevê a atuação do Setor Privado na Saúde. \\
\hline
\end{tabular}

Mário Maia (PDT) fez apenas uma proposição sobre Assistência Farmacêutica:

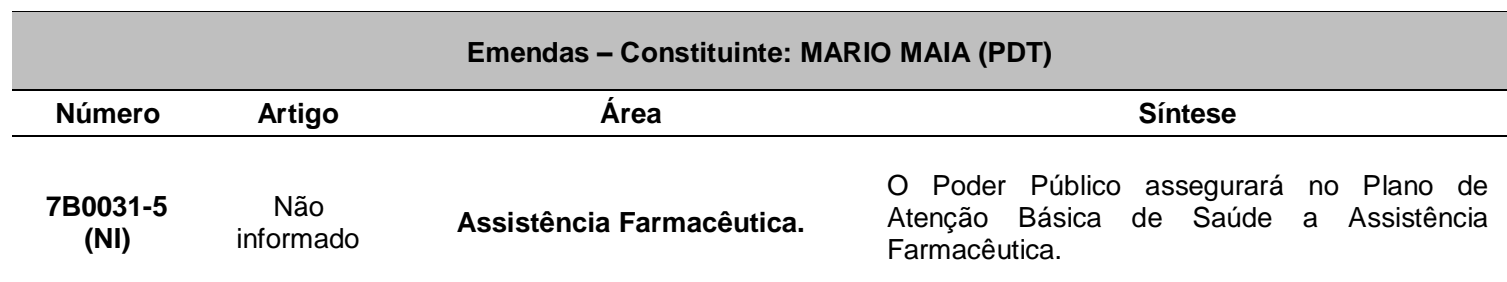

Nilson Gibson (PMDB) concentrou as suas propostas na área de medicamentos e da organização do sistema de saúde:

\begin{tabular}{|c|c|c|c|}
\hline \multicolumn{4}{|c|}{ Emendas - Constituinte: NILSON GIBSON (PMDB) } \\
\hline Número & Artigo & Área & Síntese \\
\hline $\begin{array}{l}\text { 7B0032-3 } \\
(17 / 05 / 87)\end{array}$ & $2^{\circ}$ e $3^{\circ}$ & Sistema de Saúde. & $\begin{array}{l}\text { As ações e serviços constituíam um Sistema } \\
\text { Único, hierarquizado e regionalizado. }\end{array}$ \\
\hline $\begin{array}{l}\text { 7B0075-7 } \\
(18 / 05 / 87)\end{array}$ & $\mathrm{NI}$ & Medicamentos. & Trata das políticas públicas de medicamentos. \\
\hline $\begin{array}{l}7 \mathrm{~B} 0085-4 \\
(18 / 05 / 87)\end{array}$ & $\mathrm{NI}$ & Automedicação. & $\begin{array}{l}\text { Proibição da propaganda de medicamentos, a } \\
\text { fim de evitar a automedicação. }\end{array}$ \\
\hline
\end{tabular}

Cesar Carls Neto (PDS) propôs o estabelecimento de um plano nacional de desenvolvimento na Saúde:

\begin{tabular}{cccc}
\hline \multicolumn{4}{c}{ Emendas - Constituinte: CESAR CARLS NETO (PDS) } \\
\hline Número & Artigo & Área & Síntese \\
\hline
\end{tabular}




\begin{tabular}{|c|c|c|c|c|}
\hline $\begin{array}{l}\text { 7B0037-4 } \\
(17 / 05 / 87)\end{array}$ & $\begin{array}{l}\text { Onde } \\
\text { couber }\end{array}$ & $\begin{array}{l}\text { Plano Nacional de } \\
\text { Desenvolvimento. }\end{array}$ & $\begin{array}{l}\text { Estabelecer o plano nacional } \\
\text { desenvolvimento na Saúde e outros. }\end{array}$ & de \\
\hline
\end{tabular}

Homero Santos (PFL) apresentou emenda para que o tema do consumo de bebidas alcoólicas e tabaco fosse retirados do projeto da $\mathrm{CF}$, por entender que não se tratava de matéria constitucional:

\begin{tabular}{cccc}
\hline \multicolumn{4}{c}{ Emendas - Constituinte: HOMERO SANTOS (PFL) } \\
\hline Número & Artigo & Área & Síntese \\
\hline $\begin{array}{c}\text { 7B0038-2 } \\
(\mathbf{1 8 / 0 5 / 8 7 )}\end{array}$ & $\begin{array}{c}\text { Suprime-se } \\
7^{0}\end{array}$ & $\begin{array}{c}\text { Consumo de Bebidas Alcoólicas } \\
\text { e Tabaco. }\end{array}$ & Alega não se tratar de matéria constitucional. \\
\hline
\end{tabular}

Borges da Silveira (PMDB) tratou de vários aspectos da saúde: medicamentos, bebidas alcoólicas e tabaco, recursos financeiros, setor privado de saúde e direito à saúde.

\begin{tabular}{|c|c|c|c|}
\hline \multicolumn{4}{|c|}{ Emendas - Constituinte: BORGES DA SILVEIRA (PMDB) } \\
\hline Número & Artigo & Área & Síntese \\
\hline $\begin{array}{l}\text { 7B0043-9 } \\
(18 / 05 / 87)\end{array}$ & $4^{\circ} \S 1^{\circ} 0$ & $\begin{array}{c}\text { Consumo de Bebidas Alcoólicas } \\
\text { e Tabaco. }\end{array}$ & Alega não se tratar de matéria constitucional. \\
\hline $\begin{array}{l}\text { 7B0044-7 } \\
(18 / 05 / 87)\end{array}$ & $4^{\circ} \S 2^{\circ}$ & $\begin{array}{l}\text { Desapropriação ou expropriação } \\
\text { serviços de saúde privados. }\end{array}$ & $\begin{array}{l}\text { Prevê a desapropriação ou expropriação, } \\
\text { mediante indenização. }\end{array}$ \\
\hline $\begin{array}{l}\text { 7B0045-5 } \\
(18 / 05 / 87)\end{array}$ & $\begin{array}{l}\text { Suprime-se } \\
4^{\circ} \S 2^{\circ}\end{array}$ & $\begin{array}{l}\text { Desapropriação ou expropriação } \\
\text { serviços de saúde privados. }\end{array}$ & $\begin{array}{l}\text { Prevê a supressão do artigo, posto a sua } \\
\text { regulação na legislação existente. }\end{array}$ \\
\hline $\begin{array}{l}7 \mathrm{~B} 0046-3 \\
(18 / 05 / 87)\end{array}$ & $5^{\circ}$ & $\begin{array}{l}\text { Produção e distribuição de } \\
\text { medicamentos e outros. }\end{array}$ & $\begin{array}{l}\text { Disciplina a produção e distribuição de } \\
\text { medicamentos, imunobiológicos } \\
\text { hemoderivados. }\end{array}$ \\
\hline $\begin{array}{l}\text { 7B0047-1 } \\
(18 / 05 / 87)\end{array}$ & $7^{\circ}$ & $\begin{array}{l}\text { Propaganda de medicamentos, } \\
\text { bebidas alcoólicas e tabaco. }\end{array}$ & $\begin{array}{l}\text { Delega a lei especial disciplinar a propaganda } \\
\text { de medicamentos e outros. }\end{array}$ \\
\hline $\begin{array}{l}\text { 7B0048-0 } \\
(18 / 05 / 87)\end{array}$ & $3^{\circ} \S 2^{\circ}$ & Recursos Financeiros à Saúde. & $\begin{array}{l}\text { Prevê que os dispêndios federais com a saúde } \\
\text { sejam superiores a } 10 \% \text { do PIB e os recursos } \\
\text { estaduais } 15 \% \text { de suas receitas. }\end{array}$ \\
\hline $\begin{array}{l}\text { 7B0049-8 } \\
(18 / 05 / 87)\end{array}$ & $1^{\circ} \S 2^{\circ}$ & Direito à Saúde. & $\begin{array}{l}\text { Defende que a lei determine a maneira de } \\
\text { efetivação do direito à saúde. }\end{array}$ \\
\hline
\end{tabular}


Moema São Thiago (PDT) ao organizar as ações de saúde, propôs o direito à assistência integral e terapêutica multiprofissional:

\begin{tabular}{|c|c|c|c|}
\hline \multicolumn{4}{|c|}{ Emendas - Constituinte: MOEMA SÃO THIAGO (PDT) } \\
\hline Número & Artigo & Área & Síntese \\
\hline $\begin{array}{l}\text { 7B0051-0 } \\
(18 / 05 / 87)\end{array}$ & $\mathrm{NI}$ & Assistência Multiprofissional. & $\begin{array}{l}\text { Garantir assistência terapêutica multiprofissional } \\
\text { à saúde. }\end{array}$ \\
\hline $\begin{array}{l}\text { 7B0052-8 } \\
(18 / 05 / 87)\end{array}$ & $\mathrm{NI}$ & Assistência Integral à Saúde. & $\begin{array}{l}\text { Todo cidadão tem o direito à assistência integral } \\
\text { à saúde. }\end{array}$ \\
\hline $\begin{array}{l}7 B 0053-6 \\
(18 / 05 / 87)\end{array}$ & $\mathrm{NI}$ & Organização da Saúde. & $\begin{array}{l}\text { Estabelece a saúde como direito e organiza as } \\
\text { ações de saúde e sistemas. }\end{array}$ \\
\hline
\end{tabular}

Felipe Mendes (PDS) ocupou-se em propostas de organização do Sistema Único de Saúde, com ações e serviços hierarquizados e regionalizados, além das questões de normatização, execução e controle. Mas tratou também dos serviços privados de saúde e da substituição do termo saúde relacionado à 'soberania nacional' por 'saúde coletiva e individual'.

\begin{tabular}{|c|c|c|c|}
\hline \multicolumn{4}{|c|}{ Emendas - Constituinte: FELIPE MENDES (PDS) } \\
\hline Número & Artigo & Área & Síntese \\
\hline $\begin{array}{l}\text { 7B0056-1 } \\
(18 / 05 / 87)\end{array}$ & 5ㅇ § único & Saúde Coletiva e Individual. & $\begin{array}{l}\text { Substitui a expressão "soberania nacional" por } \\
\text { "saúde coletiva e individual". }\end{array}$ \\
\hline $\begin{array}{l}\text { 7B0057-9 } \\
(16 / 05 / 87)\end{array}$ & $4^{\circ} \S 2^{\circ}$ & $\begin{array}{l}\text { Desapropriação ou expropriação } \\
\text { serviços de saúde privados. }\end{array}$ & $\begin{array}{l}\text { Prevê a supressão do artigo, por ser tratado em } \\
\text { legislação específica. }\end{array}$ \\
\hline $\begin{array}{l}\text { 7B0058-7 } \\
(16 / 05 / 87)\end{array}$ & $4^{\circ}$ & Saúde: dever do Estado. & $\begin{array}{l}\text { Obrigatoriedade do Estado nas ações de saúde } \\
\text { (normatização, execução e controle). }\end{array}$ \\
\hline $\begin{array}{l}\text { 7B0059-5 } \\
(16 / 05 / 87)\end{array}$ & $2^{\circ}$ & Sistema Único de Saúde. & $\begin{array}{l}\text { As ações e serviços públicos de saúde serão } \\
\text { hierarquizados, regionalizados e constituirão um } \\
\text { sistema único. }\end{array}$ \\
\hline $\begin{array}{l}\text { 7B0071-4 } \\
(18 / 05 / 87)\end{array}$ & $1 \stackrel{0}{1}$ & Saúde: dever do Estado. & $\begin{array}{l}\text { A saúde como dever do Estado, sem qualquer } \\
\text { discriminação. }\end{array}$ \\
\hline
\end{tabular}

Heráclito Fortes (PMDB) tratou da propaganda de medicamentos, bebidas alcoólicas e tabaco: 


\begin{tabular}{cccl}
\hline \multicolumn{3}{c}{ Emendas - Constituinte: HERÁCLITO FORTES (PMDB) } \\
\hline Número & Artigo & Área & Síntese \\
\hline $\begin{array}{c}\text { 7B0065-0 } \\
(\mathbf{1 8 / 0 5 / 8 7 )}\end{array}$ & $7^{0}$ & $\begin{array}{c}\text { Propaganda de Medicamentos, } \\
\text { Bebidas Alcoólicas e Tabaco. }\end{array}$ & $\begin{array}{l}\text { Lei disciplinará a propaganda de bebidas } \\
\text { alcoólicas, tabaco, medicamentos e outros. }\end{array}$ \\
\hline
\end{tabular}

Mauricio Nasser (PMDB) tratou dos crimes na área da saúde, como a negligência, omissão e imperícia, e do uso de seres humanos como cobaias em pesquisas.

\begin{tabular}{|c|c|c|c|}
\hline \multicolumn{4}{|c|}{ Emendas - Constituinte: MAURICIO NASSER (PMDB) } \\
\hline Número & Artigo & Área & Síntese \\
\hline $\begin{array}{l}\text { 7B0066-8 } \\
(18 / 05 / 87)\end{array}$ & $\mathrm{NI}$ & Crime na área da saúde. & $\begin{array}{l}\text { São crimes a transmissão de infecção } \\
\text { hospitalar, a negligência, omissão e imperícia no } \\
\text { tratamento. }\end{array}$ \\
\hline $\begin{array}{l}\text { 7B0067-6 } \\
(18 / 05 / 87)\end{array}$ & $\mathrm{NI}$ & Uso de cobaias. & $\begin{array}{l}\text { É proibido o uso de seres humanos como } \\
\text { cobaias em pesquisas médico-científicas e em } \\
\text { experimentos. }\end{array}$ \\
\hline
\end{tabular}

O senador José Agripino (PFL) tratou apenas dos serviços privados de saúde:

\begin{tabular}{cccl}
\hline & & Emendas - Constituinte: SEN. JOSE AGRIPINO (PFL) \\
\hline Número & Artigo & Área & Síntese \\
\hline $\begin{array}{c}\text { 7B0068-4 } \\
(\mathbf{1 8 / 0 5 / 8 7 )}\end{array}$ & $\begin{array}{c}\text { Suprima-se } \\
7^{0}\end{array}$ & $\begin{array}{c}\text { Desapropriação ou expropriação } \\
\text { serviços de saúde privados. }\end{array}$ & $\begin{array}{l}\text { Prevê a supressão do artigo, por ser tratado em } \\
\text { legislação específica. }\end{array}$ \\
\hline
\end{tabular}

Eliel Rodrigues (PMDB) tratou apenas, nas emendas, do tema dos primeiros socorros.

\begin{tabular}{|c|c|c|c|}
\hline \multicolumn{4}{|c|}{ Emendas - Constituinte: ELIEL RODRIGUES (PMDB) } \\
\hline Número & Artigo & Área & Síntese \\
\hline $\begin{array}{l}\text { 7B0070-6 } \\
(18 / 05 / 87)\end{array}$ & $\mathrm{NI}$ & Primeiros Socorros. & $\begin{array}{l}\text { Em caso de gravidade, qualquer serviço de } \\
\text { saúde (público ou privado) deve prestar } \\
\text { atendimento. }\end{array}$ \\
\hline
\end{tabular}


Sadie Hauache (PFL) abordou a questão da doação de órgãos no Brasil:

\begin{tabular}{cccc}
\hline \multicolumn{5}{c}{ Emendas - Constituinte: SADIE HAUACHE (PFL) } \\
\hline Número & Artigo & Área & Síntese \\
\hline $\begin{array}{l}\text { 7B0087-1 } \\
(\mathbf{1 8 / 0 5 / 8 7 )}\end{array}$ & $8^{\circ}$ & Doação de Órgão. & $\begin{array}{l}\text { Prevê a retirada de órgãos tecidos de } \\
\text { cadáveres, mediante autorização. }\end{array}$ \\
\hline
\end{tabular}

Paulo Macarini (PMDB) estabeleu diretrizes para a saúde, enquanto dever do Estado:

\begin{tabular}{|c|c|c|c|}
\hline \multicolumn{4}{|c|}{ Emendas - Constituinte: PAULO MACARINI (PMDB) } \\
\hline Número & Artigo & Área & Síntese \\
\hline $\begin{array}{l}\text { 7B0088-9 } \\
(18 / 05 / 87)\end{array}$ & $\mathrm{NI}$ & Diretrizes da Saúde. & $\begin{array}{l}\text { Estabelece diretrizes para Saúde como dever do } \\
\text { Estado. }\end{array}$ \\
\hline
\end{tabular}

Flavio Pamier da Veiga (PMDB) tratou da medicina informal:

\begin{tabular}{cccc}
\multicolumn{4}{c}{ Emendas - Constituinte: FLAVIO PAMIER DA VEIGA (PMDB) } \\
\hline Número & Artigo & Área & Síntese \\
\hline $\begin{array}{c}7 \text { B0094-3 } \\
(18 / 05 / 87)\end{array}$ & $\mathrm{NI}$ & Medicina Informal. & Assegura o direito à medicina informal. \\
\hline
\end{tabular}

Anna Maria Rattes (PMDB) tratou da saúde da mulher, do setor privado e do capital estrangeiro na saúde:

\begin{tabular}{|c|c|c|c|}
\hline \multicolumn{4}{|c|}{ Emendas - Constituinte: ANNA MARIA RATTES (PMDB) } \\
\hline Número & Artigo & Área & Síntese \\
\hline $\begin{array}{l}\text { 7B0096-0 } \\
(18 / 05 / 87)\end{array}$ & $2^{\circ}$ & Saúde da Mulher. & $\begin{array}{l}\text { Assistência integral e gratuita à saúde da } \\
\text { mulher. }\end{array}$ \\
\hline $\begin{array}{l}\text { 7B0148-6 } \\
(19 / 05 / 87)\end{array}$ & $4^{\circ} \S 1^{\circ}$ & Setor Privado na Saúde. & $\begin{array}{l}\text { Estabelece que o Setor Privado possa atuar na } \\
\text { cobertura assistencial à Saúde, mediante } \\
\text { contrato de Direito Público. }\end{array}$ \\
\hline $\begin{array}{l}\text { 7B0263-6 } \\
(19 / 05 / 87)\end{array}$ & $5^{\circ}$ & Capital Estrangeiro na Saúde. & $\begin{array}{l}\text { É vedada a participação de capital estrangeiro } \\
\text { nos serviços de saúde. }\end{array}$ \\
\hline
\end{tabular}


Meira Filho (PMDB) tratou da doção de órgãos no país:

\begin{tabular}{cccc}
\multicolumn{5}{c}{ Emendas - Constituinte: MEIRA FILHO (PMDB) } \\
\hline Número & Artigo & Área & Síntese \\
\hline $\begin{array}{c}7 \text { B0097-8 } \\
(18 / 05 / 87)\end{array}$ & $8^{\circ}$ & Doação de Órgãos. & Permite a doação de órgão e tecidos. \\
\hline
\end{tabular}

Jorge Viana (PMDB) abordou a questão da municipalização dos serviços de saúde:

\begin{tabular}{cccc}
\hline & & Emendas - Constituinte: JORGE VIANNA (PMDB) \\
\hline Número & Artigo & Área & Síntese \\
\hline $\begin{array}{c}7 \text { (B0097-8 } \\
(18 / 05 / 87)\end{array}$ & $8^{\circ}$ & Municipalização das ações de \\
saúde. & $\begin{array}{c}\text { Propõe a municipalização das ações de saúde e } \\
\text { a criação do Conselho Municipal de Saúde. }\end{array}$ \\
\hline
\end{tabular}

Abigail Feitosa (PMDB) tratou da saúde suplementar e da licença maternidade:

\begin{tabular}{|c|c|c|c|}
\hline \multicolumn{4}{|c|}{ Emendas - Constituinte: ABIGAIL FEITOSA (PMDB) } \\
\hline Número & Artigo & Área & Síntese \\
\hline $\begin{array}{l}\text { 7B0109-5 } \\
(18 / 05 / 87)\end{array}$ & $4^{\circ} \S 1^{\circ}$ & Saúde Suplementar. & $\begin{array}{l}\text { Prevê a existência de serviços privados de } \\
\text { saúde a fim de complementar a assistência } \\
\text { pública. }\end{array}$ \\
\hline $\begin{array}{l}\text { 7B0198-2 } \\
(19 / 05 / 87)\end{array}$ & $\mathrm{NI}$ & Licença Maternidade. & $\begin{array}{l}\text { Fica garantida a licença maternidade de } 180 \\
\text { dias. }\end{array}$ \\
\hline
\end{tabular}

Mendes Thame (PFL), agrônomo, abordou a questão das substâncias que causam danos à saúde e ao meio ambiente: 


\begin{tabular}{cccc}
\hline Número & Artigo & Área & \multicolumn{1}{c}{ Síntese } \\
\hline $\begin{array}{l}\text { 7B0115-0 } \\
(\mathbf{1 8 / 0 5 / 8 7 )}\end{array}$ & $3^{\circ}-$ XIII & $\begin{array}{c}\text { Substâncias que causam danos } \\
\text { à saúde e ao Meio Ambiente. }\end{array}$ & $\begin{array}{l}\text { Prevê o controle da produção, comercialização, } \\
\text { técnicas e utilização de substâncias nocivas à } \\
\text { saúde e ao ambiente. }\end{array}$ \\
\hline
\end{tabular}

Luiz Alfredo Salomão (PDT) previu recursos à saúde e tratou da natalidade:

\begin{tabular}{|c|c|c|c|}
\hline \multicolumn{4}{|c|}{ Emendas - Constituinte: LUIZ ALFREDO SALOMÃO (PDT) } \\
\hline Número & Artigo & Área & Síntese \\
\hline $\begin{array}{l}\text { 7B0126-5 } \\
(18 / 05 / 87)\end{array}$ & $11^{\circ}$ & Recursos à Saúde. & $\begin{array}{l}\text { Suprime no artigo a frase: “... assim que os } \\
\text { dispêndios nacionais com o Setor (saúde) } \\
\text { totalizem } 10 \% \text { do PIB". }\end{array}$ \\
\hline $\begin{array}{l}\text { 7B0127-3 } \\
(18 / 05 / 87)\end{array}$ & $3^{\circ} \S 2^{\circ}$ & Recursos à Saúde. & $\begin{array}{l}\text { Suprimi o parágrafo que trata da destinação à } \\
\text { saúde de valor superior a } 10 \% \text { do PIB. }\end{array}$ \\
\hline $\begin{array}{l}\text { 7B0140-1 } \\
(19 / 05 / 87)\end{array}$ & $1^{\circ}$ & Natalidade. & $\begin{array}{l}\text { Garante o direito de determinar o número de } \\
\text { filhos. }\end{array}$ \\
\hline
\end{tabular}

Walmor de Luca (PMDB) tratou dos medicamos e insumos:

\begin{tabular}{|c|c|c|c|}
\hline \multicolumn{4}{|c|}{ Emendas - Constituinte: WALMOR DE LUCA (PMDB) } \\
\hline Número & Artigo & Área & Síntese \\
\hline $\begin{array}{l}\text { 7B0131-1 } \\
(18 / 05 / 87)\end{array}$ & 5o § único & $\begin{array}{l}\text { Importação de insumos para } \\
\text { medicamentos. }\end{array}$ & $\begin{array}{l}\text { Estabelece o monopólio da União na importação } \\
\text { de insumos químicos, biológicos e } \\
\text { farmacêuticos para produção de medicamentos. }\end{array}$ \\
\hline
\end{tabular}

Rose de Freitas (PMDB) tratou da livre iniciativa na saúde:

\begin{tabular}{|c|c|c|c|}
\hline \multicolumn{4}{|c|}{ Emendas - Constituinte: ROSE DE FREITAS (PMDB) } \\
\hline Número & Artigo & Área & Síntese \\
\hline $\begin{array}{l}\text { 7B0139-7 } \\
(18 / 05 / 87)\end{array}$ & $\mathrm{NI}$ & Livre Iniciativa na Saúde. & $\begin{array}{l}\text { A assistência à saúde será baseada na livre } \\
\text { iniciativa, sobe a administração e controle do } \\
\text { Poder Público. }\end{array}$ \\
\hline
\end{tabular}


Bosco França (PMDB) tratou de vários temas, dentre eles: saúde privada, diretrizes da saúde e livre iniciativa na saúde.

\begin{tabular}{|c|c|c|c|}
\hline \multicolumn{4}{|c|}{ Emendas - Constituinte: BOSCO FRANÇA (PMDB) } \\
\hline Número & Artigo & Área & Síntese \\
\hline $\begin{array}{l}7 \mathrm{~B} 0141-9 \\
(18 / 05 / 87)\end{array}$ & $4^{\circ} \S 2^{\circ}$ & $\begin{array}{l}\text { Desapropriação de Serviços de } \\
\text { Saúde da iniciativa privada. }\end{array}$ & $\begin{array}{l}\text { Prevê que o Poder Público poderá intervir para } \\
\text { desapropriação de serviços de saúde da } \\
\text { iniciativa privada para viabilização da política } \\
\text { nacional de saúde. }\end{array}$ \\
\hline $\begin{array}{l}\text { 7B0142-7 } \\
(18 / 05 / 87)\end{array}$ & $2^{2-}-$ I, II, III e & Diretrizes da Saúde. & $\begin{array}{l}\text { Estabelece diretrizes da saúde, tais como: } \\
\text { integralidade, rede regionalizada e } \\
\text { hierarquizada, entre outros. }\end{array}$ \\
\hline $\begin{array}{l}\text { 7B0143-5 } \\
(18 / 05 / 87)\end{array}$ & $1^{\circ}$ & Saúde Privada. & $\begin{array}{l}\text { Prevê a livre prestação de serviços privados de } \\
\text { saúde e incentivos fiscais. }\end{array}$ \\
\hline $\begin{array}{l}\text { 7B0144-3 } \\
(18 / 05 / 87)\end{array}$ & 10 & $\begin{array}{l}\text { Direito à saúde e a livre } \\
\text { iniciativa. }\end{array}$ & $\begin{array}{l}\text { Trata a saúde como dever do Estado e direito do } \\
\text { povo e assegura a livre iniciativa privada na } \\
\text { saúde. }\end{array}$ \\
\hline $\begin{array}{l}\text { 7B0145-1 } \\
(18 / 05 / 87)\end{array}$ & $4^{\circ} \S 1^{\circ}=$ & Saúde Pública e Privada. & $\begin{array}{l}\text { A prestação de serviços de saúde ficará a cargo } \\
\text { do poder público e da iniciativa privada, } \\
\text { mediante contrato de trabalho. }\end{array}$ \\
\hline
\end{tabular}

Jitahy Magalhães (PMDB) tratou de princípio da saúde, da saúde física e mental, da doação de órgãos e do direito à saúde:

\begin{tabular}{|c|c|c|c|}
\hline \multicolumn{4}{|c|}{ Emendas - Constituinte: JUTAHY MAGALHÃES (PMDB) } \\
\hline Número & Artigo & Área & Síntese \\
\hline $\begin{array}{l}\text { 7B0146-0 } \\
(18 / 05 / 87)\end{array}$ & $\mathrm{NI}$ & Princípios da Saúde. & $\begin{array}{l}\text { Estabelece atenção à saúde pelo Poder Público } \\
\text { e iniciativa privada, trata dos preceitos de saúde, } \\
\text { acesso e financiamento. }\end{array}$ \\
\hline $\begin{array}{l}\text { 7B0158-3 } \\
(19 / 05 / 87)\end{array}$ & $\mathrm{NI}$ & Saúde física e mental. & Prevê a proteção à saúde física e mental. \\
\hline $\begin{array}{l}\text { 7B0158-3 } \\
(19 / 05 / 87)\end{array}$ & $\mathrm{NI}$ & Direito à saúde. & $\begin{array}{l}\text { A proteção da saúde é um direito de todos, } \\
\text { dever do Estado e responsabilidade social de } \\
\text { empresas e profissionais. }\end{array}$ \\
\hline $\begin{array}{l}\text { 7B0159-1 } \\
(19 / 05 / 87)\end{array}$ & $\mathrm{NI}$ & Doação de Órgãos. & $\begin{array}{l}\text { Permite o transplante de órgãos e tecidos entre } \\
\text { vivos maiores e capazes e a utilização para fins } \\
\text { terapêuticos e outros post mortem. }\end{array}$ \\
\hline
\end{tabular}

Domingos Leonelli (PMDB) abordou a atuação da saúde privada e pública: 


\begin{tabular}{|c|c|c|c|}
\hline \multicolumn{4}{|c|}{ Emendas - Constituinte: DOMINGOS LEONELLI (PMDB) } \\
\hline Número & Artigo & Área & Síntese \\
\hline $\begin{array}{c}\text { 7B00147-8 } \\
(19 / 05 / 87)\end{array}$ & $1^{\circ} \S 2^{\circ}$ & Saúde Pública e Privada. & $\begin{array}{l}\text { Prevê que os serviços de saúde serão } \\
\text { promovidos pelo Poder Público e, } \\
\text { excepcionalmente, pela iniciativa privada. }\end{array}$ \\
\hline
\end{tabular}

Geraldo Alckmin (PMDB), médico, propôs emendas referentes às instituições filantrópicas e saúde da mulher e natalidade:

\begin{tabular}{|c|c|c|c|}
\hline \multicolumn{4}{|c|}{ Emendas - Constituinte: GERALDO ALCKMIN (PMDB) } \\
\hline Número & Artigo & Área & Síntese \\
\hline $\begin{array}{l}\text { 7B0150-8 } \\
(19 / 05 / 87)\end{array}$ & $4^{\circ} \S 3^{\circ}$ & Instituições Filantrópicas. & $\begin{array}{l}\text { Estabelece que os serviços de saúde sejam } \\
\text { prestados preferencialmente por instituições } \\
\text { filantrópicas, subvencionadas pelo poder } \\
\text { público. }\end{array}$ \\
\hline $\begin{array}{l}\text { 7B0180-0 } \\
(19 / 05 / 87)\end{array}$ & $1 \stackrel{0}{1}$ & Saúde da Mulher e Natalidade. & $\begin{array}{l}\text { Assistência integral e gratuita à mulher, e } \\
\text { liberdade à natalidade. }\end{array}$ \\
\hline
\end{tabular}

Ivan Mainardi (PMDB) tratou dos medicamentos:

\begin{tabular}{|c|c|c|c|c|c|}
\hline \multicolumn{6}{|c|}{ Emendas - Constituinte: IVAN MAINARDI (PMDB) } \\
\hline Número & Artigo & Área & Síntese & & \\
\hline $\begin{array}{l}\text { 7B0153-2 } \\
(19 / 05 / 87)\end{array}$ & $7^{0} \underline{0}$ & Propaganda de Medicamentos. & $\begin{array}{l}\text { Veda a propaganda } \\
\text { medicamentos. }\end{array}$ & comercial & de \\
\hline
\end{tabular}

Persival Muniz (PMDB) tratou das questões atinentes à política de saúde:

\begin{tabular}{|c|c|c|c|}
\hline \multicolumn{4}{|c|}{ Emendas - Constituinte: PERSIVAL MUNIZ (PMDB) } \\
\hline Número & Artigo & Área & Síntese \\
\hline $\begin{array}{l}\text { 7B0157-5 } \\
(19 / 05 / 87)\end{array}$ & $\mathrm{NI}$ & Política de Saúde. & $\begin{array}{l}\text { Prevê a criação de uma política nacional } \\
\text { integrada de assistência à saúde. }\end{array}$ \\
\hline
\end{tabular}

Antero de Barros (PMDB) tratou das atividades insalubres: 


\begin{tabular}{cccc}
\hline Número & Artigo & Área & \multicolumn{1}{c}{ Síntese } \\
\hline $\begin{array}{c}\text { 7B0161-3 } \\
(19 / 05 / 87)\end{array}$ & 2 o & $\begin{array}{c}\text { Condutas deletérias a Saúde } \\
\text { Pública. }\end{array}$ & $\begin{array}{l}\text { Considera crimes inafiançáveis as condutas } \\
\text { deleterias ao Meio Ambiente e a Saúde Pública. }\end{array}$
\end{tabular}

Ismael Wanderley (PMDB) tratou da alimentação e assistência farmacêutica:

\begin{tabular}{|c|c|c|c|}
\hline \multicolumn{4}{|c|}{ Emendas - Constituinte: ISMAEL WANDERLEY (PMDB) } \\
\hline Número & Artigo & Área & Síntese \\
\hline $\begin{array}{l}\text { 7B0166-4 } \\
(19 / 05 / 87)\end{array}$ & $1 \stackrel{0}{1}$ & Alimentação. & $\begin{array}{l}\text { Inclui nos direitos inalienáveis do homem, o } \\
\text { direito a se alimentar. }\end{array}$ \\
\hline $\begin{array}{l}\text { 7B0167-2 } \\
(19 / 05 / 87)\end{array}$ & $1 \stackrel{0}{1}$ & Assistência Farmacêutica. & $\begin{array}{l}\text { Inclui o direito à assistência farmacêutica no } \\
\text { Plano de Atenção Básica à Saúde. }\end{array}$ \\
\hline
\end{tabular}

Lezio Gomes Sathler (PMDB) tratou do direito à saúde e à natalidade:

\begin{tabular}{|c|c|c|c|}
\hline \multicolumn{4}{|c|}{ Emendas - Constituinte: LEZIO GOMES SATHLER (PMDB) } \\
\hline Número & Artigo & Área & Síntese \\
\hline $\begin{array}{l}\text { 7B0174-5 } \\
(19 / 05 / 87)\end{array}$ & $1^{0}$ & $\begin{array}{l}\text { Direito à saúde e direito à } \\
\text { natalidade. }\end{array}$ & $\begin{array}{l}\text { Garante o direito à saúde e estabelece a } \\
\text { liberdade quanto à natalidade. }\end{array}$ \\
\hline
\end{tabular}

Gonzaga Patriota (PMDB) tratou da produção de medicamentos e dos serviços privados de saúde.

\begin{tabular}{|c|c|c|c|}
\hline \multicolumn{4}{|c|}{ Emendas - Constituinte: GONZAGA PATRIOTA (PMDB) } \\
\hline Número- & Artigo & Área & Síntese \\
\hline $\begin{array}{l}\text { 7B0182-6 } \\
(19 / 05 / 87)\end{array}$ & $4^{\circ} \S 2^{\circ}$ e $3^{\circ}$ & $\begin{array}{l}\text { Desapropriação dos Serviços } \\
\text { Privados e educação para a } \\
\text { saúde. }\end{array}$ & $\begin{array}{l}\text { Prevê a expropriação dos serviços privados em } \\
\text { caso de fraude e a educação para saúde como } \\
\text { objetivos da política nacional do setor. }\end{array}$ \\
\hline $\begin{array}{l}\text { 7B0184-2 } \\
(19 / 05 / 87)\end{array}$ & $5^{\circ}$ & $\begin{array}{c}\text { Produção de Medicamentos e } \\
\text { outros. }\end{array}$ & $\begin{array}{l}\text { Cabe ao poder público assegurar a produção de } \\
\text { medicamentos e outros visando a soberania } \\
\text { nacional. }\end{array}$ \\
\hline
\end{tabular}


Célia de Castro (PMDB) tratou de vários temas, dentre eles a eutanásia e o financiamento da saúde:

\begin{tabular}{|c|c|c|c|}
\hline \multicolumn{4}{|c|}{ Emendas - Constituinte: CÉLIA DE CASTRO (PMDB) } \\
\hline Número & Artigo & Área & Síntese \\
\hline $\begin{array}{l}\text { 7B0196-6 } \\
(19 / 05 / 87)\end{array}$ & $10^{\circ}$ & Eutanásia. & $\begin{array}{l}\text { Propõe que seja tratado em legislação } \\
\text { específica. }\end{array}$ \\
\hline $\begin{array}{l}\text { 7B0197-4 } \\
(19 / 05 / 87)\end{array}$ & $\mathrm{NI}$ & Política Nacional de Saúde. & $\begin{array}{l}\text { Estabelece os princípios da política nacional de } \\
\text { saúde: acesso universal, igualitário, gratuito e } \\
\text { outros. }\end{array}$ \\
\hline $\begin{array}{l}\text { 7B0199-1 } \\
(19 / 05 / 87)\end{array}$ & $\begin{array}{l}\text { Onde } \\
\text { couber }\end{array}$ & Sistema Nacional de Saúde. & $\begin{array}{l}\text { Estabelece a organização do Sistema Nacional } \\
\text { de Saúde, assistência sanitária preventiva e } \\
\text { outros. }\end{array}$ \\
\hline $\begin{array}{l}\text { 7B0200-8 } \\
(19 / 05 / 87)\end{array}$ & $4^{\circ}$ & $\begin{array}{l}\text { Normatização dos Serviços de } \\
\text { Saúde e Saúde Privada. }\end{array}$ & $\begin{array}{l}\text { Atribui ao Poder Público a normatização dos } \\
\text { serviços de saúde e prevê os serviços privados } \\
\text { de saúde. }\end{array}$ \\
\hline $\begin{array}{l}\text { 7B0201-6 } \\
(19 / 05 / 87)\end{array}$ & $3^{\circ}$ & Financiamento da Saúde. & $\begin{array}{l}\text { Estabelece os meios de financiamento dos } \\
\text { serviços públicos de saúde. }\end{array}$ \\
\hline $\begin{array}{l}\text { 7B0202-4 } \\
(19 / 05 / 87)\end{array}$ & $2^{\circ}$ & Sistema Nacional de Saúde. & Organiza o Sistema Nacional de Saúde. \\
\hline $\begin{array}{l}\text { 7B0203-2 } \\
(19 / 05 / 87)\end{array}$ & 10 & Direito à Saúde. & $\begin{array}{l}\text { A saúde é um direito do cidadão e um dever do } \\
\text { Estado. }\end{array}$ \\
\hline
\end{tabular}

Mauro Borges (PDC) tratou da doação de órgãos:

\begin{tabular}{cccc}
\hline \multicolumn{3}{c}{ Emendas - Constituinte: MAURO BORGES (PDC) } \\
\hline Número & Artigo & Área & Síntese \\
\hline $\begin{array}{l}\text { 7B0205-9 } \\
(19 / 05 / 87)\end{array}$ & $8^{0}$ & Doação de Órgãos. & $\begin{array}{l}\text { Dispõe sobre a autorização para doação de } \\
\text { órgãos e tecidos de cadáveres. }\end{array}$ \\
\hline
\end{tabular}

Stélio Dias (PFL) tratou do Sistema Único de Saúde: 


\begin{tabular}{cclc}
\hline Número & Artigo & \multicolumn{1}{c}{ Área } & \multicolumn{1}{c}{ Síntese } \\
\hline $\begin{array}{l}\text { 7B0206-7 } \\
(19 / 05 / 87)\end{array}$ & $2^{\circ}$ & Sistema Único de Saúde. & $\begin{array}{l}\text { Trata das ações e serviços de saúde, } \\
\text { hierarquizadas e regionalizadas, para } \\
\text { constituírem um Sistema Único de Saúde. }\end{array}$
\end{tabular}

Floriceno Paixão (PDT) tratou de medicamentos e assistência social:

\begin{tabular}{|c|c|c|c|}
\hline \multicolumn{4}{|c|}{ Emendas - Constituinte: FLORICENO PAIXÃO (PDT) } \\
\hline Número & Artigo & Área & Síntese \\
\hline $\begin{array}{l}\text { 7B0207-5 } \\
(19 / 05 / 87)\end{array}$ & $2^{\circ}$ & Medicamentos. & $\begin{array}{l}\text { Constitui monopólio da União, as matérias- } \\
\text { primas para produção de medicamentos. }\end{array}$ \\
\hline $\begin{array}{l}\text { 7B0208-3 } \\
(19 / 05 / 87)\end{array}$ & $1^{0}$ & Assistência Social e Médica. & $\begin{array}{l}\text { Assegura assistência social e médica gratuita as } \\
\text { pessoas carentes. }\end{array}$ \\
\hline
\end{tabular}

Gastone Righi (PTB) tratou do direto à saúde e do SUS:

\begin{tabular}{cccc}
\hline \multicolumn{4}{c}{ Emendas - Constituinte: GASTONE RIGHI (PTB) } \\
\hline Número & Artigo & Área & \multicolumn{1}{c}{ Síntese } \\
\hline $\begin{array}{c}7 \text { 7B0212-1 } \\
(\mathbf{1 9 / 0 5 / 8 7 )}\end{array}$ & $1^{\circ}$ a $4^{\circ}$ & $\begin{array}{c}\text { Direito à Saúde e Sistema Único } \\
\text { de Saúde. }\end{array}$ & $\begin{array}{l}\text { Estabelece o direito à saúde e as diretrizes do } \\
\text { Sistema Único de Saúde. }\end{array}$ \\
\hline
\end{tabular}

Rachid Saldanha Derzi (PMDB) tratou do direito à greve:

\begin{tabular}{cccc}
\hline \multicolumn{3}{c}{ Emendas - Constituinte: RACHID SALDANHA DERZI (PMDB) } \\
\hline Número & Artigo & Área & Síntese \\
\hline $\begin{array}{l}7 \mathrm{~B} 0214-8 \\
(\mathbf{1 8} / 05 / 87)\end{array}$ & $1^{\circ}$ a $4^{\circ}$ & Direito à greve. & $\begin{array}{l}\text { Veda o direito à greve aos profissionais da } \\
\text { saúde que atuem em serviços de emergência. }\end{array}$ \\
\hline
\end{tabular}

Walmir Campelo (PFL) tratou das substâncias nocivas à saúde:

\begin{tabular}{|c|c|c|c|}
\hline \multicolumn{4}{|c|}{ Emendas - Constituinte: WALMIR CAMPELO (PFL) } \\
\hline Número & Artigo & Área & Síntese \\
\hline $\begin{array}{l}\text { 7B0223-7 } \\
(19 / 05 / 87)\end{array}$ & $1^{\circ}$ a $4^{\circ}$ & Substâncias Nocivas. & $\begin{array}{l}\text { Prevê controle na comercialização e substâncias } \\
\text { que são nocivas à Saúde. }\end{array}$ \\
\hline
\end{tabular}


Jairo Carneiro (PFL) tratou do direito à maternidade:

\begin{tabular}{|c|c|c|c|}
\hline \multicolumn{4}{|c|}{ Emendas - Constituinte: JAIRO CARNEIRO (PFL) } \\
\hline Número & Artigo & Área & Síntese \\
\hline $\begin{array}{l}\text { 7B0225-3 } \\
(19 / 05 / 87)\end{array}$ & $\mathrm{NI}$ & Direito à saúde e à maternidade. & $\begin{array}{l}\text { Estabelece diversos direitos à saúde, a } \\
\text { maternidade e a assistência aos desamparados. }\end{array}$ \\
\hline
\end{tabular}

Eliézer Moreira Filho (PFL) tratou do direito à saúde e à natalidade:

\begin{tabular}{cccc}
\hline & \multicolumn{1}{c}{ Emendas - Constituinte: ELIÉZER MOREIRA FILHO (PFL) } \\
\hline Número & Artigo & \multicolumn{1}{c}{ Área } \\
\hline $\begin{array}{l}\text { 7B0227-0 } \\
(19 / 05 / 87)\end{array}$ & $\mathrm{NI}$ & Direito à saúde e natalidade. & $\begin{array}{l}\text { Estabelece a livre escolha quanto ao número de } \\
\text { filhos. }\end{array}$ \\
\hline
\end{tabular}

Doreto Campanari (PMDB) tratou da doação de órgãos:

\begin{tabular}{|c|c|c|c|}
\hline \multicolumn{4}{|c|}{ Emendas - Constituinte: DORETO CAMPANARI (PMDB) } \\
\hline Número & Artigo & Área & Síntese \\
\hline $\begin{array}{l}\text { 7B0234-2 } \\
(19 / 05 / 87)\end{array}$ & $\mathrm{NI}$ & Doação de Órgãos. & $\begin{array}{l}\text { Permite a remoção de órgãos e tecidos de } \\
\text { cadáveres, salvo manifestação contrária. }\end{array}$ \\
\hline
\end{tabular}

Orlando Pacheco (PFL) tratou, nas emendas, apenas da saúde privada:

\begin{tabular}{cccc}
\hline & \multicolumn{3}{c}{ Emendas - Constituinte: ORLANDO PACHECO (PFL) } \\
\hline Número & Artigo & Área & Síntese \\
\hline $\begin{array}{c}7 \text { (19242-3 } \\
(19 / 05 / 87)\end{array}$ & $\mathrm{NI}$ & Saúde Privada. & $\begin{array}{l}\text { Prevê que o Poder Público exerça a saúde } \\
\text { pública suplementar aos serviços privados. }\end{array}$ \\
\hline
\end{tabular}

Saboia de Carvalho (PMDB) tratou da cidadania:

$$
\text { Emendas - Constituinte: SENADOR CID SABOIA DE CARVALHO (PMDB) }
$$

$\begin{array}{llll}\text { Número } & \text { Artigo } & \text { Área } & \text { Síntese }\end{array}$




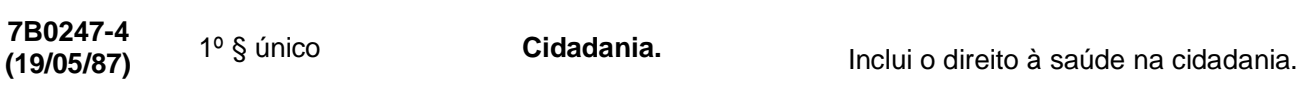

Raimundo Bezerra (PMDB) tratou da medicina preventiva:

\begin{tabular}{|c|c|c|c|}
\hline \multicolumn{4}{|c|}{ Emendas - Constituinte: RAIMUNDO BEZERRA (PMDB) } \\
\hline Número & Artigo & Área & Síntese \\
\hline $\begin{array}{l}7 B 0249-1 \\
(19 / 05 / 87)\end{array}$ & $2^{\circ} \S 5^{\circ}$ & Medicina Preventiva. & $\begin{array}{l}\text { Prioriza ações preventivas como pesquisa, } \\
\text { imuno-biologia, saneamento básico, alimentação } \\
\text { (...). }\end{array}$ \\
\hline
\end{tabular}

José Genoino (PT) tratou do dever do Estado, da discriminação e da questão da natalidade:

\begin{tabular}{cccc}
\hline \multicolumn{4}{c}{ Emendas - Constituinte: JOSÉ GENUINO NETO (PT) } \\
\hline Número & Artigo & Área & Síntese \\
\hline $\begin{array}{c}\text { 7B02450-4 } \\
(\mathbf{1 9 / 0 5 / 8 7 )}\end{array}$ & $1^{\circ}$ & $\begin{array}{c}\text { Dever do Estado } \\
\text { Discriminação } \\
\text { Liberdade à natalidade. }\end{array}$ & $\begin{array}{c}\text { Estabelece a saúde como dever do Estado, sem } \\
\text { discriminação e com direito à natalidade. }\end{array}$ \\
\hline
\end{tabular}

Paulo Ramos (PMDB) tratou da comercialização de sangue:

\begin{tabular}{|c|c|c|c|}
\hline \multicolumn{4}{|c|}{ Emendas - Constituinte: PAULO RAMOS (PMDB) } \\
\hline Número & Artigo & Área & Síntese \\
\hline $\begin{array}{l}\text { 7B02453-9 } \\
(19 / 05 / 87)\end{array}$ & $8^{\circ} \S 3^{\circ}$ & Comercialização de Sangue. & $\begin{array}{l}\text { Veda a comercialização de sangue, órgãos e } \\
\text { tecidos. }\end{array}$ \\
\hline $\begin{array}{l}\text { 7B0254-7 } \\
(19 / 08 / 87)\end{array}$ & $8^{\circ}$ & Doação de Órgãos. & $\begin{array}{l}\text { Suprimi no artigo } 8^{\circ} \text { a expressão: "e nem } \\
\text { manifestação proibitiva da família". }\end{array}$ \\
\hline $\begin{array}{l}7 B 0255-6 \\
(19 / 08 / 87)\end{array}$ & $1^{\circ}$ & $\begin{array}{l}\text { Dever do Estado } \\
\text { Discriminação } \\
\text { Liberdade à natalidade. }\end{array}$ & $\begin{array}{l}\text { Estabelece a saúde como dever do Estado, sem } \\
\text { discriminação e com direito à natalidade. }\end{array}$ \\
\hline
\end{tabular}

AdyIson Motta (PDS) tratou do livre exercício da atividade médica:

Emendas - Constituinte: ADYLSON MOTTA (PDS)

\begin{tabular}{llll} 
Número Artigo & Área & Síntese \\
\hline
\end{tabular}



Médica.

Mattos Leão (PMDB) tratou dos serviços privados de saúde:

\begin{tabular}{|c|c|c|c|}
\hline \multicolumn{4}{|c|}{ Emendas - Constituinte: MATTOS LEÃO (PMDB) } \\
\hline Número & Artigo & Área & Síntese \\
\hline $\begin{array}{l}7 \mathrm{~B} 0259-8 \\
(19 / 05 / 87)\end{array}$ & $4^{\circ} \S 2^{\circ}$ & $\begin{array}{l}\text { Intervenção nos Serviços de } \\
\text { Saúde Privados. }\end{array}$ & $\begin{array}{l}\text { Prevê que em casos de guerra ou calamidade } \\
\text { pública poderá o Estado intervir nos serviços } \\
\text { privados de Saúde. }\end{array}$ \\
\hline $\begin{array}{l}7 B 0260-1 \\
(19 / 05 / 87)\end{array}$ & $4^{\circ} \S 3^{\circ}$ & Saúde Pública e Saúde Privada. & $\begin{array}{l}\text { O Poder Público deve dar tratamento igualitário } \\
\text { aos serviços públicos e privados de saúde, } \\
\text { permitindo a livre escolha do cidadão. }\end{array}$ \\
\hline
\end{tabular}

Alarico Abibi (PMDB) tratou dos direitos à maternidade, e da criança e adolescente:

\begin{tabular}{|c|c|c|c|}
\hline \multicolumn{4}{|c|}{ Emendas - Constituinte: ALARICO ABIB (PMDB) } \\
\hline Número & Artigo & Área & Síntese \\
\hline $\begin{array}{c}\text { 7B02644 } \\
(19 / 05 / 87)\end{array}$ & $\mathrm{NI}$ & Proteção à maternidade. & $\begin{array}{l}\text { Garante o direto à maternidade, às gestantes e } \\
\text { aos pais adotantes. }\end{array}$ \\
\hline $\begin{array}{l}\text { 7B0265-2 } \\
(19 / 05 / 87)\end{array}$ & $\mathrm{NI}$ & $\begin{array}{l}\text { Recursos à Saúde e } \\
\text { Saúde Materno-Infantil. }\end{array}$ & $\begin{array}{l}\text { Estabelece percentual de mínimo de } \\
\text { investimento em saúde em } 12 \% \text { à União e } 20 \% \\
\text { aos Estados, DF e municípios. } \\
\text { Prioriza o repasse à saúde materno-infantil. }\end{array}$ \\
\hline $\begin{array}{l}\text { 7B0266-1 } \\
(19 / 05 / 87)\end{array}$ & $1 \stackrel{0}{1}$ & Criança e Adolescente. & $\begin{array}{l}\text { Assegura a todos e especialmente às crianças e } \\
\text { adolescentes atenção à saúde. }\end{array}$ \\
\hline
\end{tabular}

Jorge Arbage (PDS) tratou dos recursos à saúde:

\begin{tabular}{|c|c|c|c|}
\hline \multicolumn{4}{|c|}{ Emendas - Constituinte: JORGE ARBAGE (PDS) } \\
\hline Número & Artigo & Área & Síntese \\
\hline $\begin{array}{l}\text { 7B0273-3 } \\
(19 / 05 / 87)\end{array}$ & $3^{\circ} \S 2^{\circ}$ & Recursos à Saúde. & $\begin{array}{l}\text { Estabelece o percentual mínimo de } 10 \% \text { do } \mathrm{PIB} \\
\text { de recursos destinados à saúde. }\end{array}$ \\
\hline
\end{tabular}

Adhemar de Barros (PDT) tratou da livre iniciativa na saúde: 
Emendas - Constituinte: ADHEMAR DE BARROS FILHO (PDT)

\begin{tabular}{cccc}
\hline Número & Artigo & Área & Síntese \\
\hline $\begin{array}{c}7 \mathrm{~B} 0276-8 \\
(19 / 05 / 87)\end{array}$ & $\mathrm{NI}$ & Livre Iniciativa na Saúde. & $\begin{array}{l}\text { Assegura a livre iniciativa na saúde com } \\
\text { fiscalização do Estado. }\end{array}$ \\
\hline
\end{tabular}

Eduardo Moreira (PMDB) tratou da natalidade, pesquisa e serviços privados na saúde:

\begin{tabular}{|c|c|c|c|}
\hline Número & Artigo & Área & Síntese \\
\hline $\begin{array}{l}\text { 7B0277-6 } \\
(19 / 05 / 87)\end{array}$ & $\mathrm{NI}$ & $\begin{array}{l}\text { Liberdade à Natalidade; } \\
\text { Pesquisas em Humanos. }\end{array}$ & $\begin{array}{l}\text { Garante a liberdade à escolha do número de } \\
\text { filhos, estabelece políticas de educação quanto } \\
\text { à fertilidade; Estabelece regulamentação das } \\
\text { pesquisas em seres humanos. }\end{array}$ \\
\hline $\begin{array}{l}\text { 7B0280-6 } \\
(19 / 05 / 87)\end{array}$ & $4^{\circ} \S 2^{\circ}$ & $\begin{array}{l}\text { Desapropriação ou expropriação } \\
\text { de serviços privados de saúde. }\end{array}$ & $\begin{array}{l}\text { Prevê a intervenção, desapropriação ou } \\
\text { expropriação devido a grave irregularidade. }\end{array}$ \\
\hline
\end{tabular}

Joaquim Sucena (PMDB) tratou, dentre outros assuntos, da eutanásia e da doação de órgãos:

\begin{tabular}{|c|c|c|c|}
\hline \multicolumn{4}{|c|}{ Emendas - Constituinte: JOAQUIM SUCENA (PMDB) } \\
\hline Número & Artigo & Área & Síntese \\
\hline $\begin{array}{l}7 B 0282-9 \\
(19 / 05 / 87)\end{array}$ & $\begin{array}{l}\text { Onde } \\
\text { couber }\end{array}$ & $\begin{array}{l}\text { Livre exercício da atividade } \\
\text { médico-hospitalar. }\end{array}$ & $\begin{array}{l}\text { Assegura o livre exercício da atividade médico- } \\
\text { hospitalar para complementar o sistema único } \\
\text { de Saúde. }\end{array}$ \\
\hline $\begin{array}{l}\text { 7B0283-1 } \\
(19 / 05 / 87)\end{array}$ & $8^{\circ}$ e $10^{\circ}$ & $\begin{array}{l}\text { Doação de Órgãos; } \\
\text { Eutanásia. }\end{array}$ & $\begin{array}{l}\text { Suprime os artigos sobre doação de órgãos e } \\
\text { eutanásia, por considerar tema de legislação } \\
\text { ordinária. }\end{array}$ \\
\hline
\end{tabular}

Brandão Monteiro (PDT) tratou de medicamentos, doação de órgãos e intervenção nos serviços de saúde: 


\begin{tabular}{|c|c|c|c|}
\hline Número & Artigo & Área & Síntese \\
\hline $\begin{array}{l}\text { 7B0289-0 } \\
(19 / 05 / 87)\end{array}$ & $5^{\circ}$ & Medicamentos. & $\begin{array}{l}\text { Torna monopólio estatal a importação de } \\
\text { matéria-prima para produção de medicamentos. }\end{array}$ \\
\hline $\begin{array}{l}7 B 0290-3 \\
(19 / 05 / 87)\end{array}$ & $8^{\circ}$ & Doação de Órgãos. & $\begin{array}{l}\text { Trata da doação de órgãos, tecidos e líquidos } \\
\text { em vida e, na ausência de manifestação } \\
\text { contrária, em morte. }\end{array}$ \\
\hline $\begin{array}{l}\text { 7B0291- } \\
(19 / 05 / 87)\end{array}$ & $1^{0}$ & $\begin{array}{c}\text { Interdição nos serviços de } \\
\text { saúde. }\end{array}$ & $\begin{array}{l}\text { No interesse da saúde pública, o Estado poderá } \\
\text { intervir em projetos e obras públicas ou } \\
\text { privadas. }\end{array}$ \\
\hline
\end{tabular}

Vivaldo Barbosa (PDT) tratou do dever do Estado, entre outros:

\begin{tabular}{|c|c|c|c|}
\hline \multicolumn{4}{|c|}{ Emendas - Constituinte: VIVALDO BARBOSA (PDT) } \\
\hline Número & Artigo & Área & Síntese \\
\hline $\begin{array}{l}\text { 7B0292-0 } \\
(19 / 05 / 87)\end{array}$ & $1^{\circ}$ a $6^{\circ}$ & $\begin{array}{l}\text { Dever do Estado; } \\
\text { Sistema Nacional de Saúde; } \\
\text { Direito à Saúde; }\end{array}$ & $\begin{array}{l}\text { Saúde como bem social e direito fundamental do } \\
\text { indivíduo e da sociedade; princípio do Sistema } \\
\text { Nacional de Saúde; Decorre sobre o Direito à } \\
\text { Saúde, entre outros. }\end{array}$ \\
\hline
\end{tabular}

Maria de Lourdes Abadia (PFL) tratou, entre outros assuntos, da saúde alternativa:

\begin{tabular}{|c|c|c|c|}
\hline Número & Artigo & Área & Síntese \\
\hline $\begin{array}{l}\text { 7B0299-7 } \\
(19 / 05 / 87)\end{array}$ & $1^{\circ}$ & $\begin{array}{l}\text { Dever do Estado; } \\
\text { Direito à Saúde; } \\
\text { Discriminação. }\end{array}$ & $\begin{array}{l}\text { Estabelece a Saúde como dever do Estado e } \\
\text { um direito de todos, sem discriminação. }\end{array}$ \\
\hline $\begin{array}{l}\text { 7B0301-2 } \\
(19 / 05 / 87)\end{array}$ & $\mathrm{NI}$ & Livre Natalidade. & $\begin{array}{l}\text { Assegura a mulher a livre escolha ao número de } \\
\text { filhos. }\end{array}$ \\
\hline $\begin{array}{l}\text { 7B0326-8 } \\
(19 / 05 / 87)\end{array}$ & $4^{\underline{0}}$ & Sistemas alternativos de terapia & $\begin{array}{l}\text { Prevê os sistemas alternativos de diagnóstico, } \\
\text { terapia e imunologia. }\end{array}$ \\
\hline
\end{tabular}

Oswaldo Almeida (PL) tratou de vários assuntos, dentre eles o conceito de saúde:

Emendas - Constituinte: OSWALDO ALMEIDA (PL)

Número Artigo Área Síntese




\begin{tabular}{|c|c|c|c|}
\hline $\begin{array}{l}\text { 7B0305-5 } \\
(19 / 05 / 87)\end{array}$ & $\begin{array}{l}6^{\circ} \text { à } 10^{\circ} \text { e } \\
\text { Disposições } \\
\text { Transitórias }\end{array}$ & $\begin{array}{l}\text { Saúde Ocupacional; Propaganda } \\
\text { de Medicamentos e outros; } \\
\text { Doação de Órgãos; Fiscalização } \\
\text { de Alimentos e outros; } \\
\text { Eutanásia. }\end{array}$ & $\begin{array}{l}\text { Alega que os dispositivos são passíveis de } \\
\text { transformação durante do tempo, o que não } \\
\text { requer a sua presença na CF e sim em } \\
\text { legislação ordinária. }\end{array}$ \\
\hline $\begin{array}{l}\text { 7B0306-3 } \\
(19 / 05 / 87)\end{array}$ & $3^{\circ}$ e $6^{\circ}$ & $\begin{array}{l}\text { Financiamento da Saúde; } \\
\text { Saúde Ocupacional. }\end{array}$ & $\begin{array}{l}\text { Suprime-se o art. } 3^{\circ} \text { (financiamento da Saúde) } \\
\text { pelo art. } 6^{\circ} \text { (saúde ocupacional). }\end{array}$ \\
\hline $\begin{array}{l}\text { 7B0308-0 } \\
(19 / 05 / 87)\end{array}$ & $4^{\circ} \S 1^{\circ}$ & Serviços Privados de Saúde. & $\begin{array}{l}\text { Prevê a prestação de serviços privados de } \\
\text { saúde, conforme legislação ordinária. }\end{array}$ \\
\hline $\begin{array}{l}\text { 7B0309-8 } \\
(19 / 05 / 87)\end{array}$ & $5^{\circ}$ & $\begin{array}{l}\text { Diretrizes do Sistema Único de } \\
\text { Saúde. }\end{array}$ & $\begin{array}{l}\text { Estabelece que o Sistema de Saúde deverá } \\
\text { promover pesquisar, formar recursos humanos, } \\
\text { insumos e equipamentos científicos. }\end{array}$ \\
\hline $\begin{array}{l}\text { 7B0310-1 } \\
(19 / 05 / 87)\end{array}$ & $2^{\circ}$ e $3^{\circ}$ & $\begin{array}{l}\text { Organização do Sistema Único } \\
\text { de Saúde. }\end{array}$ & $\begin{array}{l}\text { Estabelece que as ações e serviços do Sistema } \\
\text { de Saúde integrem uma rede regionalizada e } \\
\text { hierarquizada, mediante lei ordinária. }\end{array}$ \\
\hline $\begin{array}{l}\text { 7B0311-0 } \\
(19 / 05 / 87)\end{array}$ & 10 & Conceito de Saúde. & $\begin{array}{l}\text { Direito à saúde compreende assistência } \\
\text { preventiva, médica, farmacêutica e } \\
\text { odontológica, ambulatorial e hospitalar, e } \\
\text { reabilitação. }\end{array}$ \\
\hline $\begin{array}{l}\text { 7B0312-8 } \\
(19 / 05 / 87)\end{array}$ & $1^{\circ}$ & Discriminação. & $\begin{array}{l}\text { Acrescenta que o direito à saúde seja garantido } \\
\text { a todos os brasileiros, sem qualquer distinção, } \\
\text { de acordo com mecanismos estabelecidos em } \\
\text { lei ordinária. }\end{array}$ \\
\hline
\end{tabular}

França Teixeira (PMDB) tratou, também, do dever do Estado:

\begin{tabular}{cccc}
\hline & Emendas - Constituinte: FRANÇA TEIXEIRA (PMDB) \\
\hline Número & Artigo & Área & Síntese \\
\hline $\begin{array}{l}\text { 7B0324-1 } \\
(\mathbf{1 9} / \mathbf{0 5} / \mathbf{8 7})\end{array}$ & $4^{\circ} \S 1^{\circ}$ e $2^{\circ}$ & $\begin{array}{c}\text { Dever do Estado; } \\
\text { Saúde Privada; }\end{array}$ & $\begin{array}{l}\text { Estabelece a saúde como serviço público, ao } \\
\text { qual cabe ao Estado fiscalizar; prevê a } \\
\text { existência da saúde privada suplementar e a } \\
\text { desapropriação de serviços privados de saúde. }\end{array}$ \\
\hline
\end{tabular}

Iram Saraiva (PMDB) tratou dos serviços de saúde nos municípios:

\begin{tabular}{|c|c|c|c|}
\hline \multicolumn{4}{|c|}{ Emendas - Constituinte: IRAM SARAIVA (PMDB) } \\
\hline Número & Artigo & Área & Síntese \\
\hline $\begin{array}{l}\text { 7B0329-2 } \\
(19 / 05 / 87)\end{array}$ & $\mathrm{NI}$ & $\begin{array}{l}\text { Prestação de Serviços de Saúde } \\
\text { nos Municípios. }\end{array}$ & $\begin{array}{l}\text { Estabelece que os municípios apenas prestarão } \\
\text { outros níveis de serviços de saúde, quando } \\
\text { tiverem atingidos satisfatoriamente a prestação } \\
\text { de serviços primários de saúde. }\end{array}$ \\
\hline
\end{tabular}




\section{A CONSTITUIÇÃO FEDERAL DE 1988}

\section{A. DO TEXTO DA CARTA CONSTITUCIONAL}

A Constituição Federal de 1988, fundamento jurídico-normativo do Estado Democrático de Direito, versa no caput do seu artigo $5^{\circ}$ sobre a "inviolabilidade do direito à vida, à liberdade, à igualdade, à segurança e à propriedade". São reconhecidos e protegidos, portanto, não apenas os direitos individuais, civis e políticos, como, também, os direitos sociais, considerados: “(...) a educação, a saúde, o trabalho, a moradia, o lazer, a segurança, a previdência social, a proteção à paternidade e à infância, a assistência aos desamparados, na forma desta Constituição". (AITH, 2006).

Segundo a professora Dallari, a reivindicação do "Direito à Saúde" é algo mais recente, moderno, embora esteja agregada ao rol dos "Direitos Humanos", uma busca antiga. (DALLARI, S. G, 1988). No quadro abaixo, pertencente ao primeiro título, "Dos Princípios Fundamentais", temos abordadas as questões inerentes à cidadania e à dignidade da pessoa humana, traços indissociáveis do conceito amplo de saúde e dos direitos basilares dos indivíduos, como à alimentação, à moradia digna e ao saneamento básico, por vezes, engendrado e negligenciado frente à pobreza, à marginalização e à discriminação, em dissonância ao que reza os objetivos fundamentais da República Federativa do Brasil, art. 3o, incisos III e IV.

\section{B. ANÁLISE DOS DISPOSITIVOS CONSTITUCIONAIS - SAÚDE}

\section{ART. $1^{\circ}-$ CIDADANIA E DIGNIDADE DA PESSOA HUMANA.}

O artigo $1^{\circ}$ da Constituição Federal do Brasil possui cinco incisos, que versam sobre soberania, cidadania, dignidade da pessoa humana, valores sociais do trabalho e da livre iniciativa e pluralismo político. Está situado no Título I - que trata dos Princípios Fundamentais, e possui outros três artigos sendo antecedido pelo preâmbulo a seguir: 
Preâmbulo - Nós, representantes do povo brasileiro, reunidos em Assembleia Nacional Constituinte para instituir um Estado Democrático, destinado a assegurar o exercício dos direitos sociais e individuais, a liberdade, a segurança, o bem-estar, o desenvolvimento, a igualdade e a justiça como valores supremos de uma sociedade fraterna, pluralista e sem preconceitos, fundada na harmonia social e comprometida, na ordem interna e internacional, com a solução pacífica das controvérsias, promulgamos, sob a proteção de Deus, a seguinte CONSTITUIÇÃO DA REPÚBLICA FEDERATIVA DO BRASIL.

Tabela 21: CF 88: Dos Princípios Fundamentais

Título I - Dos Princípios Fundamentais

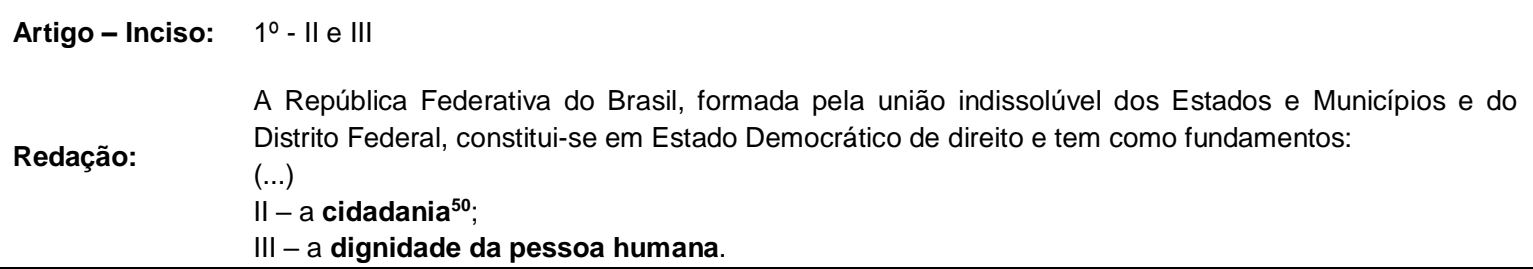

\section{Sugestões:}

As discussões preliminares do escopo do artigo 10, inaugural da carta constitucional, revelaram a preocupação em garantir o espírito norteador da nova Constituição. Situado no campo dos princípios fundamentais, o artigo $1^{\circ}$ recebeu 37 sugestões de alteração da redação. Destas, 5 versaram sobre "dignidade da pessoa humana" ou "cidadania" condições sine qua non para existência de saúde. O tema, ainda, orbitou transversalmente em "respeito ao Estado de Direito Democrático", "Garantia dos Direitos e Liberdades Individuais" e "Promoção da Justiça Social e da Pessoa Humana", através das Sugestões no. 00588, 00691, 05370, 09816 apresentadas entre abril e maio de 1987, por iniciativa dos constituintes: Irma Passoni, Jamil Haddad, Antônio Britto, José Ignácio Ferreira e Ismael Wanderley, respectivamente.

${ }^{50}$ Grifos nossos. 
Irma Passoni (Sugestão 00588) reforça ${ }^{51}$ o amparo dos princípios apresentados no artigo $1^{\underline{a}}$ no projeto constitucional elaborado pelo professor Fábio Komparato, a pedido do Partido dos Trabalhadores (PT). Segundo a constituinte, "Nesses artigos procura-se ampliar a definição clássica das finalidades do poder, colocando-se o Estado explicitamente a serviço do povo a quem é obrigado a garantir condições de vida digna e feliz". O texto final suprimiu o termo "vida digna e feliz", substituindo-o por "dignidade da pessoa humana".

As sugestões de Jamil Haddad, José Ignácio Ferreira e Ismael Wanderley versaram, em linhas gerais, sobre o "Estado Democrático de Direito" e foram parcialmente incorporadas no texto constitucional:

Sugestão 00691 (Jamil Haddad) - "A República Federativa do Brasil (...) é um estado de direito democrático fundado na soberania popular, no respeito e na garantia dos direitos e liberdades fundamentais do ser humano e no pluralismo de ideias e organização democráticas (...)".

Sugestão 05370 (José Ignácio Ferreira) - “(...) embora podendo-se argumentar que o Estado de Direito democrático seja dedutível do sistema de dispositivo da Constituição - e não de um só - achamos oportuna a presença de referência expressa, já no limiar do texto constitucional, quando da definição do Estado brasileiro (...)".

Sugestão 09816 (Ismael Wanderley) - "Será necessário que a Constituição traga estampada a configuração do Estado, na forma democrática, além de representativo, porque o exercício do poder popular estará, dessa forma, adequado à Constituição, consoante é o anseio da sociedade (...)".

Suprimido do artigo $1^{\circ}$ da Constituição Federal, o constituinte Antonio Britto apresentou sugestão de inclusão na redação final, enquanto premissa do Estado Democrático de Direito e do respeito à dignidade da pessoa humana, a

\footnotetext{
${ }^{51}$ Seu inteiro teor pode ser consultado no Diário da Assembleia Nacional Constituinte, em 29/04/87 p. 222.
} 
punição à discriminação, bem como, a garantia de igualdade entre homens e mulheres.

Sugestão 06707 (Antonio Britto) - “(..) § Ninguém será discriminado pelo nascimento, raça, cor, sexo, estado civil, religião, trabalho urbano ou rural, convicções políticas ou filosóficas, deficiência física ou mental, situação econômica ou social. § Homens e mulheres têm iguais direitos ao pleno exercício da cidadania. $\S \mathrm{A}$ lei punirá como crime inafiançável qualquer atentado aos direitos humanos.".

2. ART. 6o - DIREITOS SOCIAIS.

"Art. $6^{\circ}$ São direitos sociais a educação, a saúde, o trabalho, o lazer, a segurança, a previdência social, a proteção à maternidade e à infância, a assistência aos desamparados, na forma desta Constituição". (CF, 1988) - texto promulgado em 05.10.1988.

Foram enviados à ANC, três sugestões de elaboração do dispositivo ${ }^{52}$ concernente aos direitos sociais no país, a saber:

Sugestão 08406 - recebida em 06.05.1987. Autor: Siqueira de Campos (PDC-GO). Texto resumido: "Sugere que seja assegurado a todos o direito ao trabalho remunerado, à moradia, saúde, alimentação, educação e assistência social".

Sugestão 10359 - recebida em 22.05.1987. Entidade: Rede Mulher São Paulo - SP. Texto resumido: "Sugere sejam garantidos ao homem e à mulher direito de trabalho, moradia, educação, saúde, lazer, segurança, reforma agrária, urbana e administrativa, e dá outras providências".

Sugestão 10397 - recebida em 25.05.1987. Entidade: Conselho Federal de Nutricionistas - Neli Rodrigues Davidovich - presidente. Texto resumido: "Sugere seja assegurado a todos o direito à saúde, mediante condições dignas de trabalho, moradia, saneamento básico, educação e respeito ao meio ambiente".

Audiências Públicas - não houve.

${ }^{52}$ Baseado levantamento realizado pela Câmara dos Deputados. 
A matéria surgiu na FASE C - Anteprojeto da Subcomissão. A primeira análise da elaboração do dispositivo ocorreu na Subcomissão dos Direitos dos Trabalhadores e Servidores Públicos.

\section{DEMAIS ARTIGOS.}

O artigo $3^{\circ}$ situa-se, ainda, dentro do Título I - Dos Princípios Fundamentais. Trata dos objetivos fundamentais da República Federativa do Brasil, em seus quatro incisos.

Tabela 22: CF 88: Dos Princípios Fundamentais

Título I - Dos Princípios Fundamentais

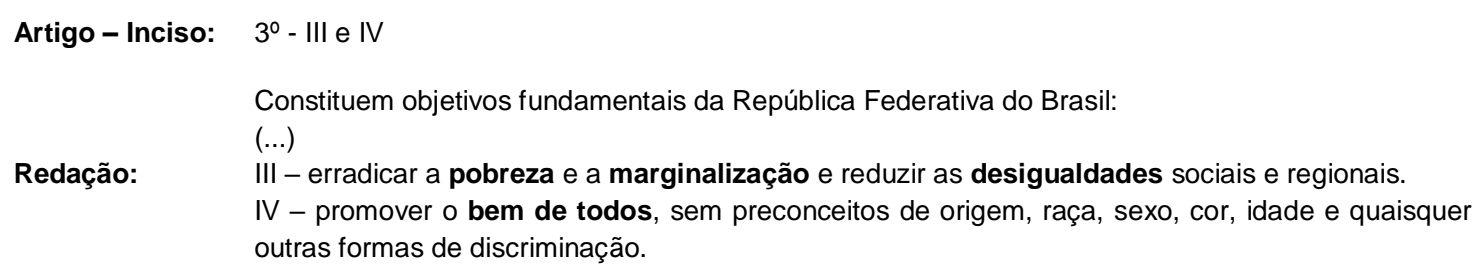

Questão indissociável da pauta sanitária, combate à pobreza e marginalização - objetivos fundamentais do país - relacionam-se diretamente às desigualdades regionais. Dois trabalhos interessantes, publicados em livros, retratam o cenário desfavorável do Brasil neste aspecto. Ricardo Abramovay (1991) apresenta os conflitos permeados pela questão da fome má-distribuição dos alimentos, subalimentação, consumismo - ressaltando o seu caráter social e econômico, para além da questão alimentícia. Manuel Correia de Andrade (1988) aborda as questões regionais e as pautas nacionais, destacando as divergências regionais. De fato, a Constituição Federal de 1988, por seu viés dirigente, ao mesmo tempo em que garante os direitos à cidadania e à dignidade, sinalizam a prioridade da erradicação da pobreza, da marginalidade e a redução da desigualdade, questões fundamentais do Direito Sanitário. 


\title{
Tabela 23: CF: Dos Direitos e das Garantias Fundamentais (Capítulo I)
}

Título II - Dos Direitos e das Garantias Fundamentais (Capítulo I)

\author{
CAPÍTULO I Dos Direitos e Deveres Individuais e Coletivos
}

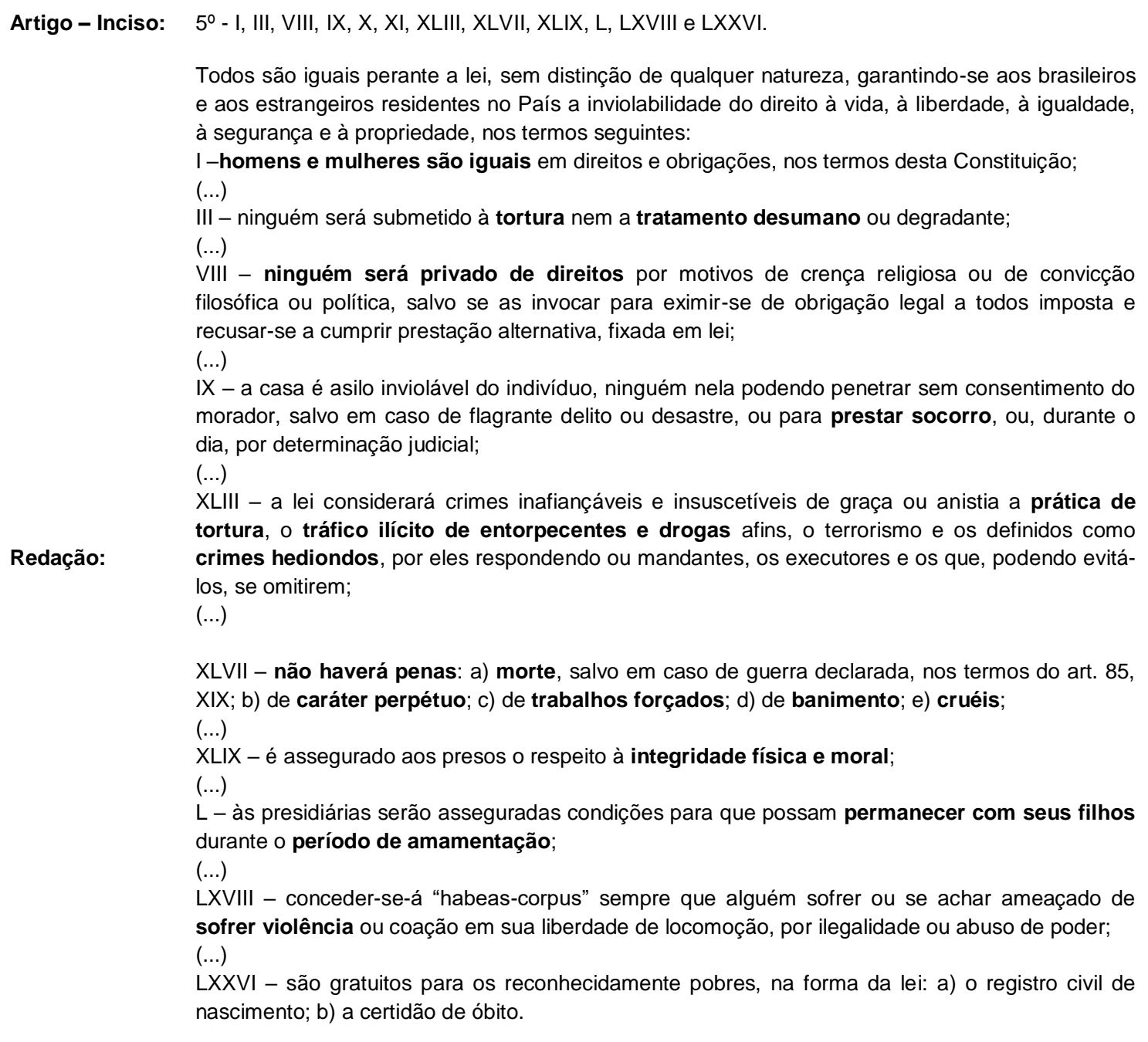

As questões sanitárias aparecem, também, nos "Direitos Sociais" - ladeadas ao direito à educação, ao trabalho, ao lazer, à segurança e à previdência social. Sendo reforçado no amparo à maternidade e na assistência ao desamparado. 
Tabela 24: CF 88: Dos Direitos e das Garantias Fundamentais (Capítulo II)

Título II - Dos Direitos e das Garantias Fundamentais (Capítulo II)

CAPÍTULO II Dos Direitos Sociais

Artigo-Inciso: $\quad 6^{\circ}$

São direitos sociais a educação, a saúde, o trabalho, o lazer, a segurança, a previdência social, a proteção à maternidade e à infância, a assistência aos desamparados, na forma desta Constituição.

Artigo - Inciso: $\quad 7^{0}-I V, I X, X I I, X I I, X V, X V I I, X V I I, X I X, X X, X X I I, X X I I, X X I V, X X V, X X V I, X X V I I, X X V I I, X X X$ XXXI, XXXIII e parágrafo único.

São direitos dos trabalhadores urbanos e rurais, além de outros que visem à melhoria de sua condição social:

$(\ldots)$

IV - salário mínimo, fixado em lei, nacionalmente unificado, capaz de atender a suas necessidades vitais básicas e às de sua família com moradia, alimentação, educação, saúde, lazer, vestuário, higiene, transporte e previdência social, com reajustes periódicos que the preservem o poder aquisitivo, sendo vedada sua vinculação para qualquer fim;

$(\ldots)$

IX - remuneração do trabalho noturno superior à do diurno;

$(\ldots)$

XII - salário-família para seus dependentes;

XIII - duração do trabalho normal não superior a oito horas diárias e quarenta e quatro semanais, facultada a compensação de horários e redução da jornada, mediante acordo ou convenção coletiva de trabalho;

$(\ldots)$

$\mathrm{XV}$ - repouso semanal remunerado, preferencialmente aos domingos;

$(\ldots)$

$\mathrm{XVII}$ - gozo de férias anuais remuneradas com, pelo menos, um terço a mais do que o salário normal;

XVIII - licença à gestante, sem prejuízo do emprego e do salário, com a duração de cento e vinte dias;

Redação: $\quad$ XIX - licença-paternidade, nos termos fixados em lei;

$X X$ - proteção do mercado de trabalho da mulher, mediante incentivos específicos, nos termos da lei;

$(\ldots)$

XXII - redução dos riscos inerentes ao trabalho, por meio de normas de saúde, higiene e segurança;

XXIII - adicional de remuneração para atividades penosas, insalubres ou perigosas, na forma da lei;

XXIV - aposentadoria;

XXV - assistência gratuita aos filhos e dependentes desde o nascimento até seis anos de idade em creches e pré-escolas;

XXVII - proteção em face da automação, na forma da lei;

XXVIII - seguro contra acidentes de trabalho, a cargo do empregador, sem excluir a indenização a que este está obrigado, quando incorrer em dolo ou culpa;

$(\ldots)$

XXX - proibição de diferença de salários, de exercício de funções e de critério de admissão por motivo de sexo, idade, cor ou estado civil;

XXXI - proibição de qualquer discriminação no tocante a salário e critérios de admissão do trabalhador portador de deficiência;

$(\ldots)$

XXXIII - proibição de trabalho noturno, perigoso ou insalubre aos menores de dezoito e de qualquer trabalho a menores de quatorze anos, salvo na condição de aprendiz;

Parágrafo único. São assegurados à categoria dos trabalhadores domésticos os direitos 
previstos nos incisos IV, VI, VIII, XV, XVII, XVIII, XIX, XXI e XXIV, bem como a sua integração à previdência social.

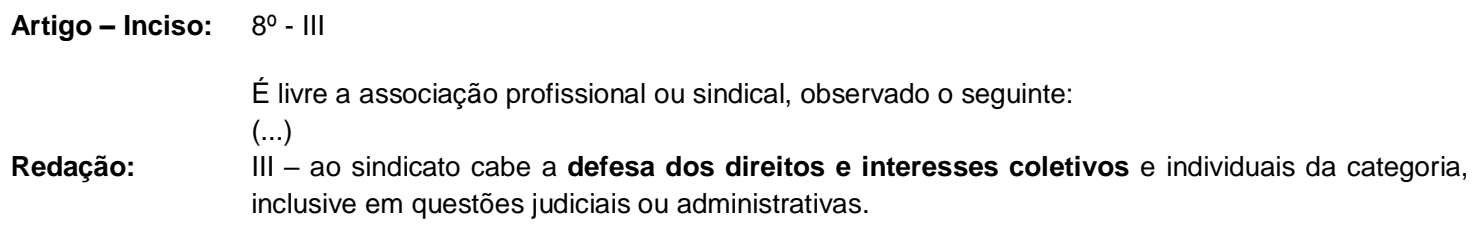

Redação: É assegurado o direito de greve, competindo aos trabalhadores decidir sobre a oportunidade de exercê-lo e sobre os interesses que devam por meio dele defender.

\section{Quanto à organização do Estado:}

\section{Tabela 25: CF 88: Da Organização do Estado (Capítulo II)}

\section{Título III - Da Organização do Estado (Capítulo II)}

\section{CAPÍTULO II Da União}

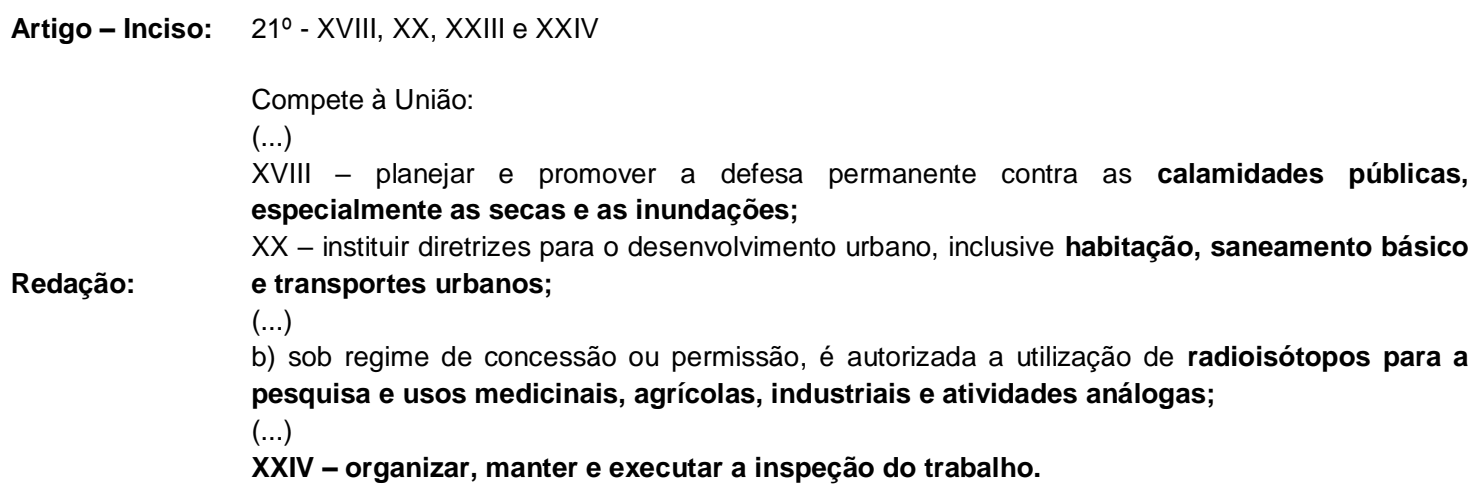

Artigo - Inciso: $\quad 23^{\circ}-$ II, V, VI, VII, VIII, IX e X Redação: 
É competência comum da União, dos Estados, do Distrito Federal e dos Municípios:

(...)

II - cuidar da saúde e assistência pública, da proteção e garantia das pessoas portadoras de deficiência;

(...)

$\mathrm{V}$ - proporcionar os meios de acesso à cultura, à educação e à ciência;

$\mathrm{VI}$ - proteger o meio ambiente e combater a poluição em qualquer de suas formas;

VII - preservar as florestas, a fauna e a flora;

VIII - fomentar a produção agropecuária e organizar o abastecimento familiar;

IX - promover programas de construção de moradias e melhoria das condições habitacionais e do saneamento básico;

$\mathrm{X}$ - combater as causas da pobreza e os fatores de marginalização, promovendo a integração social dos setores desfavorecidos.

Artigo - Inciso: 24ำ - VI, XII, XIV e XV

Compete à União, aos Estados e ao Distrito Federal legislar concorrentemente sobre:

$(\ldots)$

$\mathrm{VI}$-florestas, caça, pesca, fauna, conservação da natureza, defesa do solo e dos recursos naturais, proteção do meio ambiente e controle da poluição;

Redação: (...)

XII - previdência social, proteção e defesa da saúde

$(\ldots)$

XIV - proteção e integração social das pessoas portadoras de deficiência;

$\mathrm{XV}$ - proteção à infância e à juventude.

No âmbito da competência dos Estados, a Constituição prevê a instituição de lei complementar a fim de integrar regiões em ações de interesse comum como, por exemplo, ações de saúde.

Tabela 26: CF 88: Da Organização do Estado (Capítulo III)

Título II - Da Organização do Estado (Capítulo III)

\section{CAPÍTULO III Dos Estados Federados}

Artigo-Inciso: $\quad 25^{\circ}-\S 3^{\circ}$

Os Estados organizam-se e regem-se pelas Constituições e leis que adotarem, observados os princípios desta Constituição.

(..)

Redação: $\quad \S 3^{0}$ Os Estados poderão, mediante lei complementar, instituir regiões metropolitanas, aglomerações urbanas e microrregiões, constituídas por agrupamentos de municípios limítrofes, para integrar a organização, o planejamento e a execução de funções públicas de interesse comum.

Reza o artigo $30^{\circ}$, em seu inciso VII, que aos municípios compete a prestação de serviços de atendimento de saúde, com cooperação técnica e financeira da União e do Estado. 
Tabela 27: CF 88: Da Organização do Estado (Capítulo IV)

Título II - Da Organização do Estado (Capítulo IV)

\begin{tabular}{ll} 
CAPÍtULO IV & Dos Municípios \\
\hline Artigo-Inciso: & $30^{\circ}$ - VII \\
& $\begin{array}{l}\text { Compete aos Municípios: } \\
(\ldots) \\
\text { VII - prestar, com a cooperação técnica e financeira da União e do Estado, serviços de } \\
\text { atendimento à saúde da população. }\end{array}$ \\
\hline
\end{tabular}

No campo do trabalho, a CF 88 aborda as garantias ao trabalhador, que porventura de acidentes de trabalho ou problemas de saúde, necessitar de aposentadoria ou afastamento do serviço.

Tabela 28: CF 88: Da Organização do Estado (Capítulo VII)

Título II - Da Organização do Estado (Capítulo VII)

CAPÍtULO VII Da Administração Pública - SEÇÃO II Dos Servidores Públicos Civis

$\begin{array}{ll}\text { Artigo - Inciso: } & 40 \text { o } \\ & \text { O servidor será aposentado: } \\ & \text { I - por invalidez permanente, sendo os proventos integrais quando decorrentes de acidentes em } \\ & \text { serviço, moléstia profissional ou doença grave, contagiosa ou incurável, especificadas em } \\ & \text { lei, e proporcionais nos demais casos; } \\ & \text { (...) } \\ & \text { Redação: } \\ & \text { exercício de atividades consideradas penosas, insalubres ou perigosas. }\end{array}$




\section{CONCLUSÃO}

À guisa de conclusão, cabe-nos algumas reflexões importantes, ressaltadas neste estudo. Assunto de suma importância social, a saúde pública fora tratada, enquanto matéria constitucional, tardiamente pelos agentes mandatários do país. Percebe-se isso desde a instigação ao debate, ou melhor, a ausência da matéria no cenário político brasileiro, até o seu tratamento quando chegada às casas legislativas. Vários foram os motivos aqui elencados: primeiro, o próprio conceito de saúde não pairava em nossas mentes enquanto 'completo bem estar físico, mental e social', ou seja, uma completa anacronia com a própria Organização Mundial de Saúde, cujo o tema já era visto com espectro 'amplo da vida' na década de 40 , momento de nossa primeira alusão incipiente, quase ingênua, na Constituição de 1946. Garantir recursos financeiros poderia significar investimento, mas sem uma mudança na 'concepção de saúde', pouco êxito alcançou-se no que foi preconizado pela OMS. Um segundo aspecto, comprovado em 1987-88, é que sem mobilização social, a pauta sanitária não ganharia força na Constituinte, os assuntos de certa maneira chegaram 'amadurecidos' nas emendas ao anteprojeto, fruto principalmente da $8^{\text {a }}$ Conferência Nacional de Saúde. De fato, foram necessários 'condutores' desse processo, parlamentares solitários que efetivaram a presença da pauta sanitária no texto constitucional, como Eduardo Jorge, que apresentou $1 / 4$ das preposições à $C F$ 88, versando sobre temas cruciais ainda hoje à saúde. Cabe ressaltar, num terceiro aspecto, já dito no decorrer da pesquisa, que as eleições para a ANC 1987-88 representaram uma profunda mudança no cenário político brasileiro, ascendendo ao poder representantes da classe trabalhadora e dos movimentos sociais, como nunca antes visto - ainda que minoritariamente. Esses constituintes além de expoentes de 'outras vozes' até então caladas no Parlamento, representaram o incômodo necessário para que as pautas sociais emergissem no debate nacional. De outro lado, a princípio, imaginar-se-ia o recrutamento político das carreiras sanitárias enquanto suficientes à pauta da saúde pública, 'mais parlamentares da área da saúde, mais leis sanitárias'. Vimos que muitos 
sanitaristas já chegaram ao Parlamento comprometidos com causas adversas e bandeiras específicas. Evidenciamos a dinâmica da composição do parlamento brasileiro nas ANCs de 1946 e 1987-88, que demonstrou o recrutamento político de profissões tradicionais na sociedade brasileira advocacia e medicina - o que nos possibilitou incidir sobre o 'perfil sanitário' dos constituintes responsáveis pela elaboração das cartas de 1946 e 1988. Os dados comparativos indicaram que se manteve a proporção de representantes das duas áreas - direito e saúde - com uma ligeira queda em 1988, em razão de alguns fatores: surgimento de novos cursos de graduação (administração de empresas, por exemplo) e a ascensão das classes populares ao parlamento (com baixa escolaridade). O estudo identificou, também, que nem todos os profissionais da saúde atuaram em defesa desta nas ANCs, além disso, houve grande interferência de parlamentares de outras áreas em defesa, por exemplo, da participação da iniciativa privada na saúde. Assim, pudemos concluir que os avanços e as conquistas de direitos expressos nas Constituições estudadas são oriundos do progresso da pauta sanitária nos movimentos sociais, na ampliação da participação política e da atuação isolada de parlamentares que se tornaram expoentes da luta sanitária brasileira. Portanto, o recrutamento político das profissões da saúde não logrou êxito determinante no avanço sanitário. As conquistas da ANC de 1987-88 foram alcançadas pelos movimentos sociais e pela própria consolidação do 'conceito de saúde', capitaneada por esses parlamentares solitários, frente ao corporativismo de outros seguimentos. A 'luz no fim do túnel', concluímos, está no fortalecimento da sociedade civil organizada e da ocupação dos espaços de participação política por representantes forjados na luta sanitária brasileira. 


\section{REFERÊNCIAS}

\section{Anais das Assembleias Nacionais Constituintes:}

ANAIS da Assembleia Geral Constituinte e Legislativa de 1823 (versão eletrônica: http://www2.camara.gov.br/publicacoes);

ANAIS da Assembleia Geral Constituinte e Legislativa de 1890-91 (versão eletrônica: http://www2.camara.gov.br/publicacoes);

ANAIS da Assembleia Geral Constituinte e Legislativa de 1933-34 (versão eletrônica: http://www2.camara.gov.br/publicacoes);

ANAIS da Assembleia Geral Constituinte e Legislativa de 1946 (versão eletrônica: http://www2.camara.gov.br/publicacoes);

ANAIS da Assembleia Geral Constituinte e Legislativa de 1987-88 (versão eletrônica: http://www2.camara.gov.br/publicacoes).

(versões eletrônicas:http://www2.camara.leg.br/atividadelegislativa/legislacao/Constituicoes_Brasileiras/anteriores.html) Constituição Política do Império do Brasil de 1824;

Constituição da República dos Estados Unidos do Brasil de 1891; Constituição da República dos Estados Unidos do Brasil de 1934; Constituição da República dos Estados Unidos do Brasil de 1937; Constituição dos Estados Unidos do Brasil de 1946; Constituição da República Federativa do Brasil de 1967; Constituição da República Federativa do Brasil de1988. ABRAMOVAY, R. O que é fome. 1 ed. São Paulo: Ed. Brasiliense, 1991. ANDRADE, M. C. A revolução de 30: da República Velha ao Estado Novo. Porto Alegre: Mercado Aberto, 1988.

AITH, F. Teoria geral do direito sanitário brasileiro. 2006. Tese (Doutorado em Serviços de Saúde Pública) - Faculdade de Saúde Pública, Universidade de São Paulo, 2006. Acesso em: 2019-07-23.

ALKMIM, A. C. O paradoxo do conceito de representação política. Revista de Ciência Política, v. 22, n. 1, p. 56-71, jan./jun., 2013.

ALVES, M.; ALDA, J. 0 método nas ciências naturais e sociais, pesquisa quantitativa e qualitativa. 2. ed. São Paulo: Pioneira, 1998. 
AROUCA, A. S. A reforma sanitária brasileira. Tema - Radis, n. 11, nov., 1988.

ASSEMBLEIA NACIONAL CONSTITUINTE. Constituição Política do Império do Brasil, 1824. (versão eletrônica: http://www2.camara.leg.br/atividadelegislativa/legislacao/Constituicoes_Brasileiras/anteriores.html)

BALEEIRO, A. 1946. Coleção Constituições Brasileiras. Senado Federal, Brasília, DF, 2015.

BACKES, A. L. A sociedade no Parlamento: imagens da Assembleia Nacional Constituinte de 1987/1988. Câmara dos Deputados, Edições Câmara, 2008.

BERTOLOZZI, M. R.; GRECO, R. M. As políticas de saúde no Brasil: reconstrução histórica e perspectivas atuais. Revista da Escola de Enfermagem da U S P, v. 30, n. 3, p. 380-398, 1996.

BONAVIDES, Paulo.; ANDRADE, Paes de. História constitucional do Brasil, $3^{\mathrm{a}}$ ed. Rio de Janeiro: Paz e Terra, 1991.

BOBBIO, Norberto. Dicionário de Política. Brasília: Editora Universidade de Brasília, 1992.

BRAGA, S. S. Quem foi quem na Constituinte de 1946: um perfil socioeconômico e regional da Constituinte de 1946. Brasília, 1998.

BRASIL. Ministério da Saúde. Relatório final da VIII Conferência Nacional de Saúde. Brasília, 1986.

BRASIL. Ministério da Saúde. Assessoria de Comunicação Social. Lei Orgânica de Saúde. $2^{\circ}$ ed. Brasília, 1991.

BRASIL. Ministério da Saúde. Relatório Final da IX Conferência Nacional de Saúde. Brasília, 1992.

BUSS, P. M. Saúde e desigualdade: o caso do Brasil. In: BUSS. P.M.: LABRA, M.E. (org.). Sistemas de Saúde: continuidades e mudanças. São Paulo, Hucitec/Fiocruz, 1995. p.61-102.

CAMPOS, G. W. D. S. et al. Tratado de Saúde Coletiva. Fiocruz, p. 871, 2006.

CAMPOS, Gastão Wagner de Sousa. Reforma da reforma: repensando a saúde. 2. ed. Hucitec: São Paulo, 1997. 
CARVALHO, G. de C. M. O movimento atual do SUS: a ousadia de cumprir e fazer cumprir a lei. Saúde sociedade, v.2, n.I , p.9-24, 1993.

COELHO, I. B. Democracia sem equidade: um balanço da reforma sanitária e dos dezenove anos de implantação do Sistema Único de Saúde no Brasil. Ciência \& Saúde Coletiva, v. 15, n. 1, p. 171-183, 2010.

COHN, AMÉLIA http://www.scielo.br/scielo.php?script=sci_arttext\&pid=S010264451989000400009 (1989)

COMISSÃO NACIONAL DA REFORMA SANITÁRIA, 1986, http://bvsms.saude.gov.br/bvs/publicacoes/cd05_08.pdf

CORVAL, P. R. S. Democracia Representativa. Revista de Informação Legislativa, ano 52, n. 206, abr./jun., 2015.

CARVALHO, B. G.; MARTIN, G. B \& CONDONI, Jr.; A organização do Sistema de Saúde no Brasil. In: Andrade, S. M.; Soares, D. A. \& Cordoni, Jr., Bases da Saúde Coletiva, Londina: UEL, 2001.

COSTA, A. BAHIA, L, CONTE, D. A saúde da mulher e o SUS. Revista Saúde em Debate, 2007.

DALLARI, S. G. Uma nova disciplina: o direito sanitário. Revista de Saúde Pública, v. 22, n. 4, p. 327-334, 1988.

DALLARI, S. G. A Construção do Direito à Saúde no Brasil. Revista de Direito Sanitário, v. 9, n. 3, p. 9-34, 2009.

DALLARI, S. G. A Participação Popular e o Direito à Saúde no Sistema Nacional de Saúde Brasileiro. Revista de Direito Sanitário, v. 6, n. 1/2/3, p. 924, 2005.

DALLARI, S. G.; NÚNES JÚNIOR, V. S. Direito Sanitário. 1ª. ed. São Paulo: Editora Verbatim, 2010.

DIAS, N. M. O. Mulheres “Sanitaristas de Pés Descalços”. 1. ed. São Paulo: Hucitec, 1991.

DOURADO, D. DE A. Regionalização e federalismo sanitário no Brasil. 2010.

ESCOREL, S. Reviravolta na saúde: origem e articulação do movimento sanitário. Rio de Janeiro, 1993. Tese (mestrado), ENSP/Fiocruz.

FINKELMAN, J. Caminhos da saúde pública no Brasil. Rio de Janeiro: 
Editora FIOCRUZ, 2002.

FIOCRUZ, 2019, FIOCRUZ, Biblioteca Virtual Sérgio Arouca https://bvsarouca.icict.fiocruz.br/sanitarista05.html).

GALVÃO, M. A. M. Origem das Políticas de Saúde Pública no Brasil: Do Brasil-Colônia a 1930, 2012. Disponível em: <http://bvsms.saude.gov.br/bvs/publicacoes/origem_politicas_saude_publica_br asil.pdf>

GUIMARÃES, Ulysses. Discurso do Deputado Ulysses Guimarães. Revista Direito GV, São Paulo, p. 595-602, jul./dez. 2008. Editorial.

IYDA, M. Cem anos de saúde pública: a cidadania negada. São Paulo, Universidade Estadual Paulista, 1994.

KELSEN, H. O que é justiça? A justiça, o direito e a política no espelho da ciência. São Paulo: Martins Fontes, 1997.

LASSALLE, F. A essência da Constituição. 4. ed. Rio de Janeiro: Líber Juris, 1993.

LUZ, M.T. Medicina e ordem política brasileira: políticas e instituições de saúde (1850-1930). Graal, Rio de Janeiro, 1982.

MARQUES, S. B. Judicialização do Direito à Saúde. Revista de Direito Sanitário, v. 9, p. 65-72, 2008.

MENDES, E. V. (org). Distrito sanitário: o processo social de mudança das políticas sanitárias do Sistema Único de Saúde. São Paulo, HUCITEC/ABRASCO, 1993.

MENDES, Gilmar Ferreira. Introdução. Audiência Pública - Saúde. Brasília: Supremo Tribunal Federal, 2009.

MIRANDA, Pontes. Comentários à Constituição de 1946. Volume I,São Paulo: Max Limonad, 1953.

MIRANDA, Pontes. Comentários à Constituição de 1946. Volume II,São Paulo: Max Limonad, 1953.

MORAES, I. A. DE. A história da saúde pública / vigilância sanitária no Brasil. p. 1-64, 2010.

MUSSA, F.; Direito à saúde e democracia sanitária: experiências brasileiras. p. 85-90, 2015. 
NETO, N. C. O Direito Sanitário Brasileiro: Conceito, Princípios e a Interface com outros Ramos da Ciência Jurídica.Revista Jurídica - CCJ, v. 18, p. 103-128, 2014.

NOGUEIRA, O. 1824. Coleção Constituições Brasileiras. Senado Federal, Brasília, DF, 2015.

NORONHA, J. C. D.; LEVCOVITZ, E. AIS-SUDS-SUS: Os caminhos do direito à saúde. In: GUIMARÂE $S$,R. ; T AVARE S,R. (org). Saúde e sociedade no Brasil - anos 80. Rio de Janeiro, Relume do Mará, 1994.p. 73-111.

OLIVEIRA, G. J. Efetivação do Direito à Saúde: ampliação do debate e renovação da agenda. Revista de Direito Sanitário, v. 16, n. 1, p. 78-86, 2015. OLIVEIRA, M. M. Fontes de informações sobre a Assembleia Nacional Constituinte de 1987: quais são, onde buscá-las e como usá-las. Brasília: Senado Federal, 1987.

PACHECO, A. M. Direito Constitucional. 2 ed. Porto Alegre: Verbo Jurídico, 2013.

PAIM, J. S. Reforma Sanitária Brasileira: contribuição para a compreensão e crítica. Tese de Doutorado. Instituto de Saúde Coletiva da Universidade Federal da Bahia, 2007.

PAIVA, C. H. A; TEIXEIRA, L. A. Reforma Sanitária e a Criação do Sistema Único de Saúde: notas sobre contextos e autores. História, Ciências, Saúde - Manguinhos. Rio de Janeiro: FIOCRUZ, v. 21, n. 1, jan-mar, 2014 - p. 15-35. PITKIN, H. F. O conceito de representação. In CARDOSO, F. H e MARTINS, C. E., Política e Sociedade, v. 2, Companhia Editora Nacional, 1979.

, The conception de representation. Berkeley, CA, Los Angeles, CA and London: University of California Press, 1967.

Wittgenstein and Justice. Berkeley, CA, Los Angeles, CA and London: University of California Press.

PORTO, W. C. 1937. Coleção Constituições Brasileiras. Senado Federal, Brasília, DF, 2015.

RIBEIRO, W. C.; JULIO, R. S. Direito e Sistemas Públicos. v. 15, p. 447-460, 1988.

RODRIGUES, L. M. Mudanças na classe política brasileira. [s.l: s.n.]. 
SCAFF, Fernando Facury. O direito à saúde e os Tribunais. In: NUNES, Antônio José Avelãs; SCAFF, Fernando Facury (Orgs.). Os Tribunais e o direito à saúde. Porto Alegre: Livr. do Advogado, 2011.

SCHWARTZ, G.A.D. Tempo e Direito na Construção da Saúde. R. Dir. sanit., São Paulo v.15 n.3, p. 68-84, nov. 2014/fev. 2015.

A autopoiese do sistema sanitário. Revista de Direito Sanitário, São Paulo, v. 4, n. 1, p. 50-59, 2003.

. Direito à saúde: efetivação em uma perspectiva sistêmica. Porto Alegre: Livr. do Advogado, 2001.

Gestão compartida sanitária no Brasil: possibilidade de efetivação do direito à saúde. In: SCHWARTZ, Germano (Org). A saúde sob os cuidados do direito. Passo Fundo: UPF Ed., 2003. p. 108-162.

SOUZA, Renildo Rehem. O sistema público de saúde brasileiro. Brasília: Ministério da Saúde, 2002.

TÁCITO, C. 1988. Coleção Constituições do Brasil. Senado Federal, Brasília, DF, 2015.

TOBERGTE, D. R. As ações do Serviço Sanitário e da Liga Paulista contra a Tuberculose no combate à tísica em São Paulo (1892-1917). USP, 2016. TOJAL, S. B. DE B. Direito Sanitário e Saúde Pública: Coletânea de Textos. Ministério da Saúde, Brasília, DF, 2003.

VIAL, M. S. O perfil dos parlamentares da Câmara dos Deputados - quadro comparativo da $48^{\mathrm{a}}$ com a 52a Legislatura. Câmara dos Deputados, Brasília, DF, 2007.

WORLD HEALTH ORGANIZATION. Constitution of the world health organization. Ten years of the World Health Organization, n. January 1984, p. 1-18, 1958. 


\section{X - APÊNDICE}

\section{CONSTITUINTES DE $1946^{53}$}

\section{DEPUTADOS/SENADORES:}

001

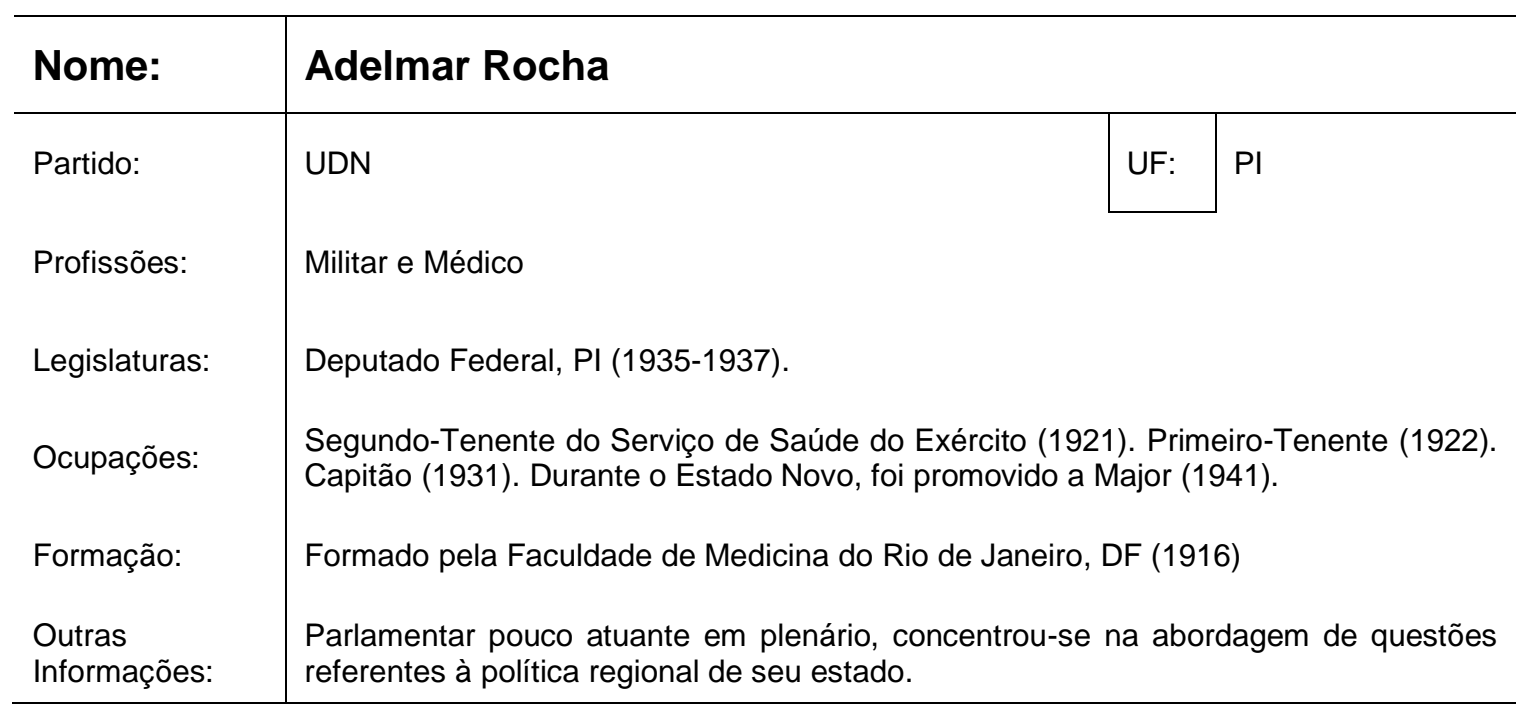

\section{2}

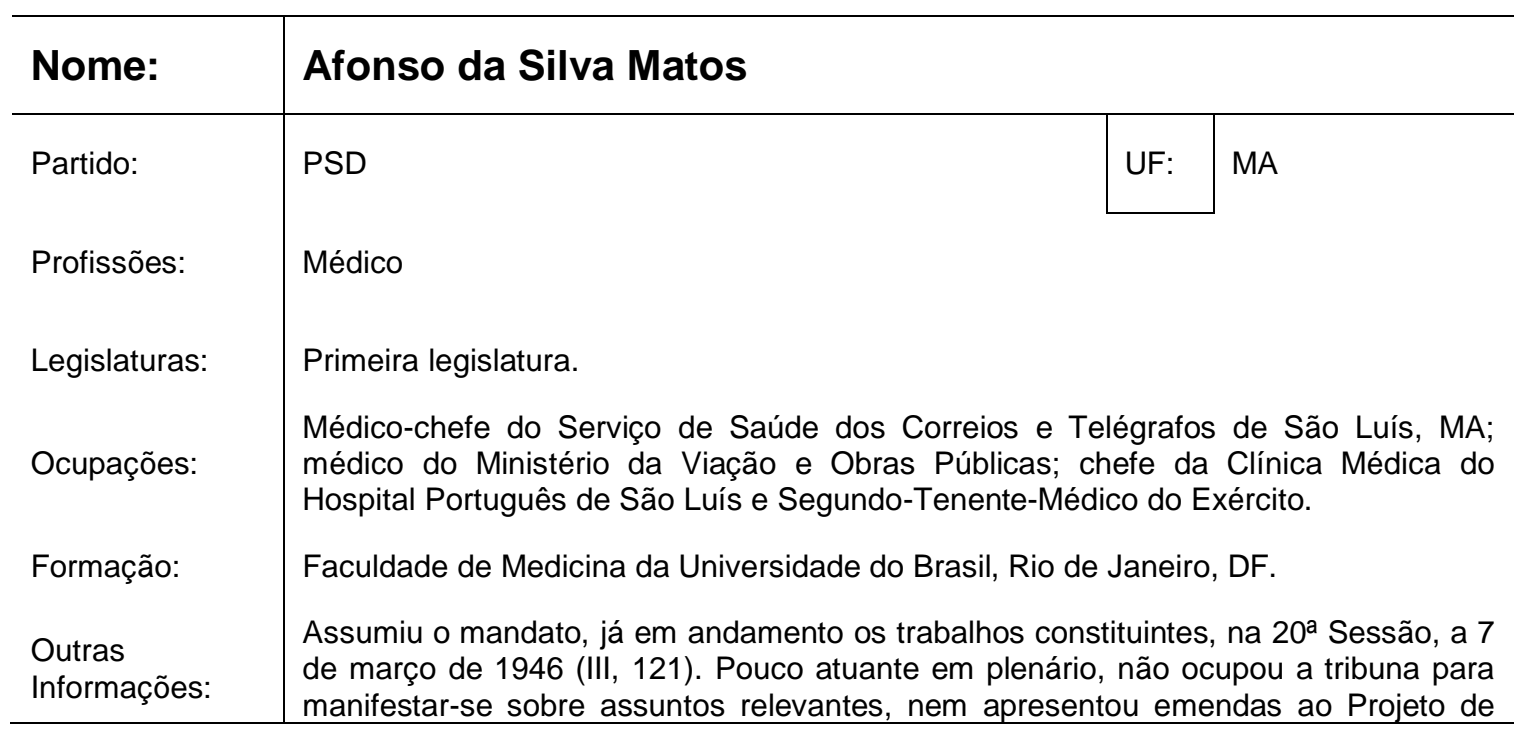

53 Informações baseadas nos estudos de Sérgio Braga: "Quem foi quem na Assembleia Constituinte de $1946 "$. 
Constituição.

003

\begin{tabular}{l|l|l|l}
\hline Nome: & \multicolumn{2}{l}{ Agostinho Monteiro } & \multicolumn{2}{l}{} \\
\hline Partido: & UDN & PA \\
Profissões: & Proprietário de Terras, Médico e Jornalista \\
Legislaturas: & Deputado Estadual, PA (1926-1930). \\
Ocupações: & $\begin{array}{l}\text { Além da Medicina, exerceu o jornalismo no Pará e publicou trabalhos sobre } \\
\text { problemas econômicos da região amazônica. }\end{array}$ \\
Formação: & $\begin{array}{l}\text { Faculdade de Medicina do Rio de Janeiro, DF (1912). } \\
\text { Outras } \\
\text { Informações: }\end{array}$ & $\begin{array}{l}\text { Foi membro da Comissão de Investigação Econômica e Social, onde apresentou } \\
\text { relatório sobre o tema Alimentação. Parlamentar ativo em plenário. }\end{array}$ \\
\hline
\end{tabular}

004

\begin{tabular}{|c|c|c|}
\hline Nome: & Agrícola de Barros & \\
\hline Partido: & UDN & MT \\
\hline Profissões: & \multicolumn{2}{|l|}{ Médico e Jornalista } \\
\hline Legislaturas: & \multicolumn{2}{|c|}{$\begin{array}{l}\text { Vereador em Cuiabá, MT (1929-1930). Deputado Estadual Constituinte, MT (1935- } \\
\text { 1937). }\end{array}$} \\
\hline Ocupações: & \multicolumn{2}{|c|}{$\begin{array}{l}\text { Médico da Secretaria de Saúde de Mato Grosso (1924-1925). Diretor do } \\
\text { Departamento de Saúde Pública de Mato Grosso (1925-1927). Médico legista da } \\
\text { polícia de Cuiabá, MT (1930). Como jornalista, foi fundador e Diretor de Jornais. }\end{array}$} \\
\hline Formação: & \multicolumn{2}{|c|}{$\begin{array}{l}\text { Formado pela Faculdade de Medicina do Rio de Janeiro, DF, e em Odontologia pela } \\
\text { Faculdade Hahnemanniana do Rio de Janeiro, DF (1923) }\end{array}$} \\
\hline $\begin{array}{l}\text { Outras } \\
\text { Informações: }\end{array}$ & \multicolumn{2}{|c|}{$\begin{array}{l}\text { Parlamentar de postura independente e progressista, concentrou sua atuação na } \\
\text { abordagem de questões referentes ao problema da extinção dos territórios criados } \\
\text { durante o Estado Novo, e na denúncia de violências policiais. }\end{array}$} \\
\hline
\end{tabular}


005

\begin{tabular}{l|l|l|l}
\hline Nome: & \multicolumn{2}{l}{ Alarico Pacheco } \\
\hline Partido: & UDN & UF: & MA \\
Profissões: & Médico, Professor Universitário e Militar \\
Legislaturas: & $\begin{array}{l}\text { Deputado Estadual por três legislaturas seguidas no Maranhão, durante a República } \\
\text { Velha (1920-1924; 1924-1928; 1928-1930). Deputado Estadual (1935-1937). } \\
\text { Médico do Corpo de Bombeiros (1910). Capitão-Médico (1914-1918). Diretor do }\end{array}$ \\
Ocupações: & $\begin{array}{l}\text { Instituto de Medicina Legal do Maranhão (1918-1941). } \\
\text { Formação: }\end{array}$ & $\begin{array}{l}\text { Formado pela Faculdade de Medicina da Bahia (1909). } \\
\text { Outras } \\
\text { Informações: }\end{array}$ & $\begin{array}{l}\text { Parlamentar pouco atuante em plenário, apenas ocupou a tribuna para participar dos } \\
\text { debates referentes à política maranhense. }\end{array}$ \\
\hline
\end{tabular}

006

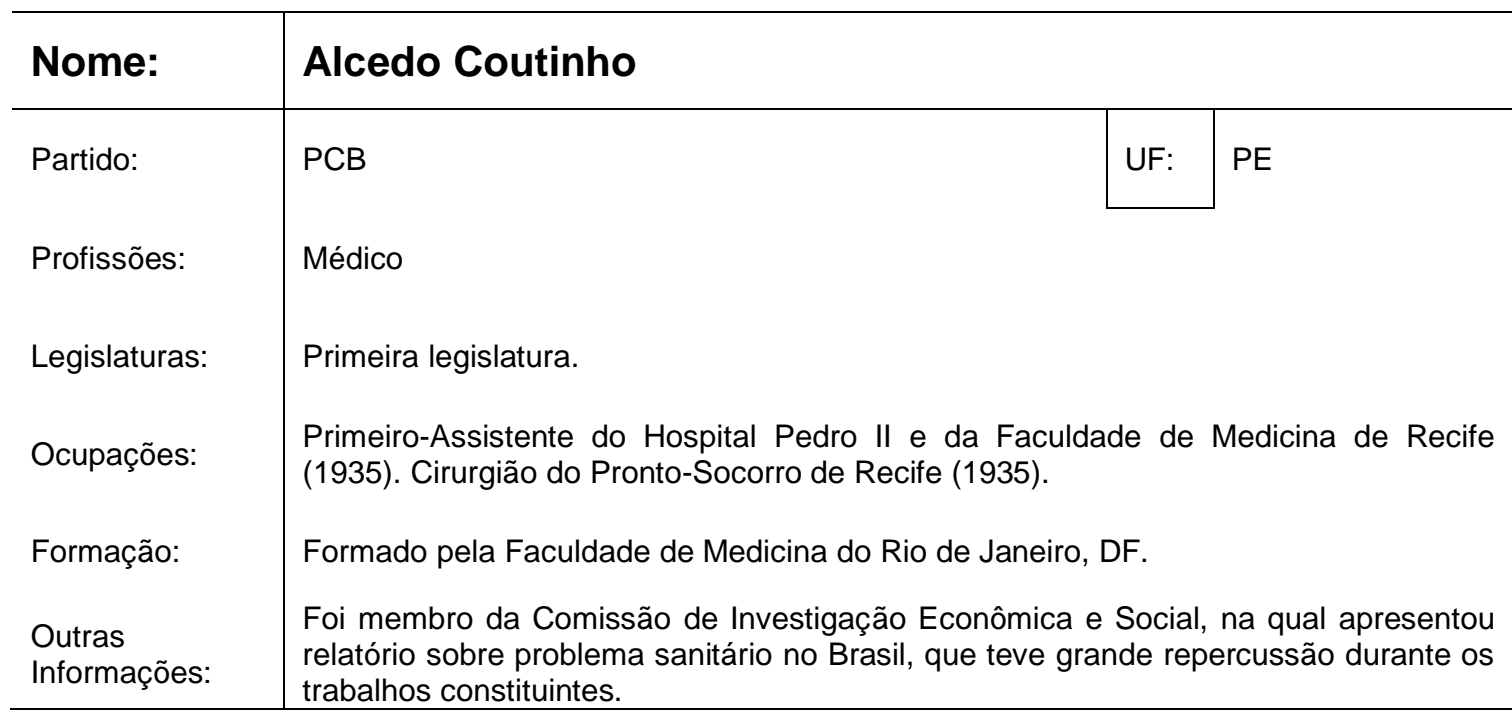

007

\begin{tabular}{l|l|l|l}
\hline Nome: & Antônio Correia & \multicolumn{2}{l}{} \\
\hline Partido: & UDN & UF: & PI \\
Profissões: & Médico e Professor & \\
Legislaturas: & Primeira legislatura. &
\end{tabular}




\begin{tabular}{l|l}
\cline { 2 - 2 } $\begin{array}{l}\text { Ocupações: } \\
\text { Formação: }\end{array}$ & $\begin{array}{l}\text { Durante o Estado Novo, foi professor da Escola Normal Oficial de Teresina, PI (1938- } \\
1944) .\end{array}$ \\
$\begin{array}{ll}\text { Outras } \\
\text { Informações: }\end{array}$ & $\begin{array}{l}\text { Concentrou sua atuação na participação nos debates travados em plenário sobre } \\
\text { política piauiense e na denúncia de violências policiais cometidas pelo governo Dutra. }\end{array}$
\end{tabular}

008

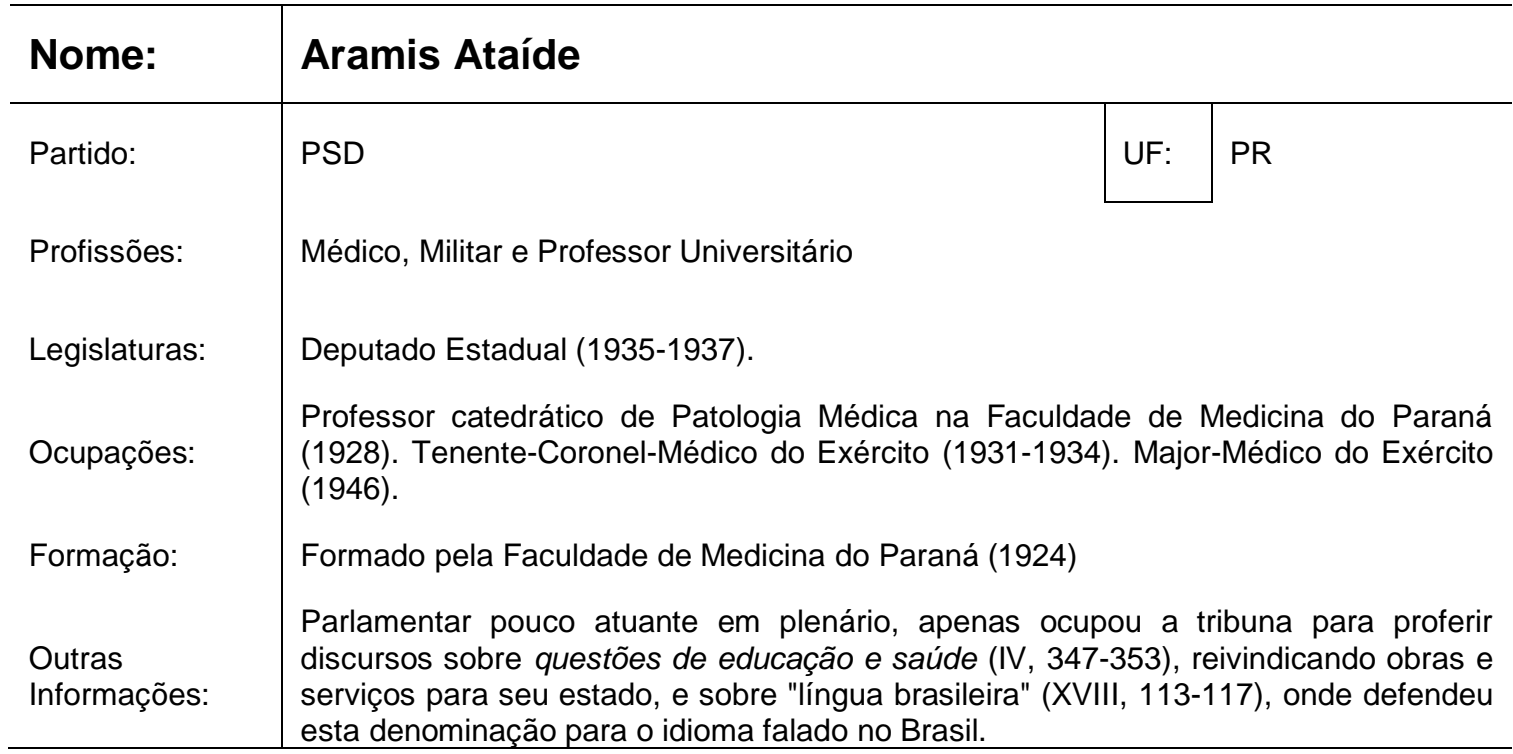

009

\begin{tabular}{l|l|l|l}
\hline Nome: & \multicolumn{2}{|l|}{ Augusto Varela } \\
\hline Partido: & PSD & UF: & RN \\
Profissões: & Médico, Proprietário de Terras e Professor \\
Legislaturas: & $\begin{array}{l}\text { Eleito Deputado Estadual pelo Rio Grande do Norte, não chegou a exercer o } \\
\text { mandato em virtude da Revolução de 30. Deputado Estadual Constituinte pelo PP - } \\
\text { Partido Popular, no Rio Grande do Norte (1935-1937) } \\
\text { Clinicou em Natal (1922-1930). Professor da Escola de Farmácia de Natal (sem } \\
\text { data). Inspetor sanitário nos Portos de Macau, RN (1931-1942). Durante o Estado } \\
\text { Novo, foi Diretor do Hospício de Alienados de Natal (1942-1945), além de exercer a } \\
\text { medicina em diversas outras instituições de saúde. Foi também fazendeiro e } \\
\text { plantador de algodão no Rio Grande do Norte. }\end{array}$ \\
Ocupações: & $\begin{array}{l}\text { Formado pela Faculdade de Medicina da Bahia (1922) } \\
\text { Formação: }\end{array} \quad \begin{array}{l}\text { Apresentou 25 emendas ao Projeto de Constituição, a maior parte delas co- } \\
\text { assinadas por seu companheiro de bancada Dioclécio Duarte (PSD/RN). Destacam- } \\
\text { se as de no 1.437, aumentando de 25 para 30 anos a idade mínima exigida para o } \\
\text { exercício do cargo de Ministro de Estado; no 1.624, obrigando o Governo a criar um } \\
\text { Ministério da Saúde independente do Ministério da Educação e Cultura; no 1.630, } \\
\text { concedendo estabilidade aos funcionários públicos interinos e extranumerários; e a }\end{array}$ \\
Outras \\
Informações:
\end{tabular}




\begin{tabular}{l|l|l|l}
\hline Nome: & \multicolumn{2}{|l}{ Bastos Tavares } & \multicolumn{2}{l}{ UF: } & \multicolumn{2}{l}{ RJ } \\
\hline Partido: & PSD & Proprietário de Terras e Médico \\
Profissões: & Deputado Estadual (1935-1937). Prefeito de Campos (1936). \\
Legislaturas: & $\begin{array}{l}\text { Foi Diretor de Higiene Municipal de Campos e Presidente da Companhia Usinas } \\
\text { Nacionais } \\
\text { Ocupações: }\end{array}$ \\
Formação: & $\begin{array}{l}\text { Formado pela Faculdade de Medicina do Rio de Janeiro, DF (1918). } \\
\text { Parlamentar ativo em plenário, concentrou sua atuação na defesa da classe dos } \\
\text { usineiros e da política implementada pelo IAA - Instituto do Açúcar e do Álcool. }\end{array}$ \\
\hline $\begin{array}{l}\text { Outras } \\
\text { Informações: }\end{array}$
\end{tabular}

\section{1}

\begin{tabular}{l|l|l|l}
\hline Nome: & \multicolumn{2}{|l}{ Batista Luzardo } \\
Partido: & PSD & UF: & \multicolumn{2}{l}{ RS } \\
Profissões: & Advogado, Proprietário de Terras e Médico \\
Legislaturas: & Deputado Federal pela legenda Aliança Libertadora, RS (1924-1928) \\
Ocupações: & Consultório de medicina em Uruguaiana, RS (1919). \\
Formação: & $\begin{array}{l}\text { Formado pela Faculdade Nacional de Medicina, no Rio de Janeiro, DF (1916). } \\
\text { Outras } \\
\text { Informações: }\end{array}$ & $\begin{array}{l}\text { Participou ativamente do combate ao surto de peste bubônica em Uruguaiana, pelo } \\
\text { que obteve grande popularidade junto à população local (1919). }\end{array}$ \\
\hline
\end{tabular}

\section{2}

\begin{tabular}{l|l|l|l}
\hline Nome: & Bayard Lima & \multicolumn{2}{l}{} \\
\hline Partido: & PSD & UF: & RS \\
\cline { 3 - 4 } & &
\end{tabular}




\begin{tabular}{l|l}
\cline { 2 - 2 } $\begin{array}{l}\text { Profissões: } \\
\text { Legislaturas: }\end{array}$ & Militar e Médico \\
Ocupações: & Primeira legislatura. \\
Formação: & $\begin{array}{l}\text { Formado pelo Faculdade de Medicina do Rio de Janeiro (1930). } \\
\text { Pouco atuante em plenário, apenas ocupou a tribuna para proferir discurso } \\
\text { defendendo a única emenda de sua autoria ao Projeto de Constituição, a de no } 722, \\
\text { estipulando que "a União auxiliará os Municípios e cidades de fronteira, visando à } \\
\text { valorização dessas zonas e os interesses internacionais da Nação }\end{array}$ \\
\hline $\begin{array}{l}\text { Outras } \\
\text { Informações: }\end{array}$
\end{tabular}

\section{3}

\begin{tabular}{|c|c|c|c|}
\hline Nome: & Ben & & \\
\hline Partido: & PDT & UF: & DF \\
\hline Profissões: & \multicolumn{3}{|c|}{ Médico e Professor } \\
\hline Legislaturas: & \multicolumn{3}{|c|}{ Primeira legislatura. } \\
\hline Ocupações: & \multicolumn{3}{|c|}{$\begin{array}{l}\text { Exerceu a profissão de médico, tendo clinicado em diversos sindicatos (1937-1945). } \\
\text { Foi também professor de Química no Colégio Pedro II }\end{array}$} \\
\hline Formação: & \multicolumn{3}{|c|}{ Formado pela Faculdade de Medicina do Rio de Janeiro, DF (1937) } \\
\hline $\begin{array}{l}\text { Outras } \\
\text { Informações: }\end{array}$ & \multicolumn{3}{|c|}{$\begin{array}{l}\text { Enviou à Mesa da Assembléia várias indicações solicitando ao Poder Executivo o } \\
\text { atendimento a demandas sociais da população de baixa renda no Distrito Federal. }\end{array}$} \\
\hline
\end{tabular}

\section{4}

\begin{tabular}{l|l|l|l}
\hline Nome: & Caires de Brito & UF: & SP \\
\hline Partido: & PCB & \multicolumn{2}{l}{} \\
Profissões: & Médico e Jornalista & \\
Legislaturas: & Primeira legislatura. \\
Ocupações: & Exerceu a profissão de médica na Bahia e em São Paulo. \\
Formação: & $\begin{array}{l}\text { Formado pela Faculdade de Medicina da Bahia (1940) } \\
\text { Em plenário, teve destacada atuação na defesa dos interesses das classes } \\
\text { trabalhadoras, tendo ocupado a tribuna várias ocasiões para apoiar reivindicações } \\
\text { populares. }\end{array}$ \\
\hline $\begin{array}{l}\text { Outras } \\
\text { Informações: }\end{array}$
\end{tabular}


015

\begin{tabular}{l|l|l|l}
\hline Nome: & \multicolumn{2}{l}{ Carlos Nogueira } & UF: PA \\
\hline Partido: & PSD & Advogado, Funcionário Público e Dentista \\
Profissões: & $\begin{array}{l}\text { Primeira legislatura. } \\
\text { Legislaturas: }\end{array}$ & $\begin{array}{l}\text { Durante o Estado Novo, foi inspetor do Ministério do Trabalho, funcionário da } \\
\text { Prefeitura do Distrito Federal e da Caixa Econômica Federal } \\
\text { Ocupações: }\end{array}$ & $\begin{array}{l}\text { Formado em Odontologia (1930); Formado pela Faculdade de Direito da } \\
\text { Universidade do Brasil no Rio de Janeiro, DF (1941). } \\
\text { Parlamentar pouco atuante em plenário, apresentou 1 emenda ao Projeto de } \\
\text { Constituição, a de no 2.824, equiparando os salários dos magistrados e funcionários } \\
\text { da Justiça do Distrito Federal aos dos demais servidores da mesma categoria nos } \\
\text { Estados. }\end{array}$ \\
Formação: & $\begin{array}{l}\text { Outras } \\
\text { Informações: }\end{array}$ \\
\hline
\end{tabular}

\section{6}

\begin{tabular}{l|l|l|l}
\hline Nome: & Diógenes Magalhães Silveira & UF: & GO \\
\hline Partido: & PSD & Médico & \multicolumn{2}{|l}{} \\
Profissões: & Primeira legislatura. \\
Legislaturas: & Proprietário de Casa de Saúde. \\
Ocupações: & Formado pela Faculdade de Medicina de Belo Horizonte, MG (1916) \\
Formação: & Não apresentou emendas ao Projeto de Constituição. \\
Outras &
\end{tabular}

\section{7}

\begin{tabular}{l|l|l|l}
\hline Nome: & Epílogo de Campos & UF: & PA \\
\hline Partido: & UDN & Médico e Fazendeiro & \\
Profissões: & Primeira legislatura. &
\end{tabular}




\begin{tabular}{l|l}
\cline { 2 - 2 } Ocupações: & Sem informações. \\
Formação: & $\begin{array}{l}\text { Formado pela Faculdade de Medicina e Cirurgia do Pará (1939). } \\
\begin{array}{l}\text { Outras } \\
\text { Informações: }\end{array}\end{array} \quad \begin{array}{l}\text { Concentrou sua atuação na remessa à Mesa da Assembléia de inúmeros } \\
\text { requerimentos e indicações abordando questões referentes à organização da } \\
\text { administração pública e a problemas geoeconômicos de sua região de origem. }\end{array}$ \\
\hline
\end{tabular}

\section{8}

\begin{tabular}{|c|c|c|c|}
\hline Nome: & Eras & & \\
\hline Partido: & UDN & UF: & PR \\
\hline Profissões: & \multicolumn{3}{|c|}{ Médico e Professor Universitário } \\
\hline Legislaturas: & \multicolumn{3}{|c|}{ Deputado Estadual Constituinte, PR (1935- } \\
\hline Ocupações: & \multicolumn{3}{|c|}{$\begin{array}{l}\text { Livre-docente de Clínica Cirúrgica na Faculdade de Medicina da Universidade do } \\
\text { Paraná (1927). Professor catedrático de Clínica Urológica na Faculdade de Medicina } \\
\text { do Paraná (1931). }\end{array}$} \\
\hline Formação: & \multicolumn{3}{|c|}{ Formado pela Faculdade de Medicina do Rio de Janeiro, DF (1925) } \\
\hline $\begin{array}{l}\text { Outras } \\
\text { Informações: }\end{array}$ & \multicolumn{3}{|c|}{$\begin{array}{l}\text { Concentrou sua atuação na abordagem de questões referentes ao problema da } \\
\text { educação e na defesa da reintegração ao Paraná. }\end{array}$} \\
\hline
\end{tabular}

\section{9}

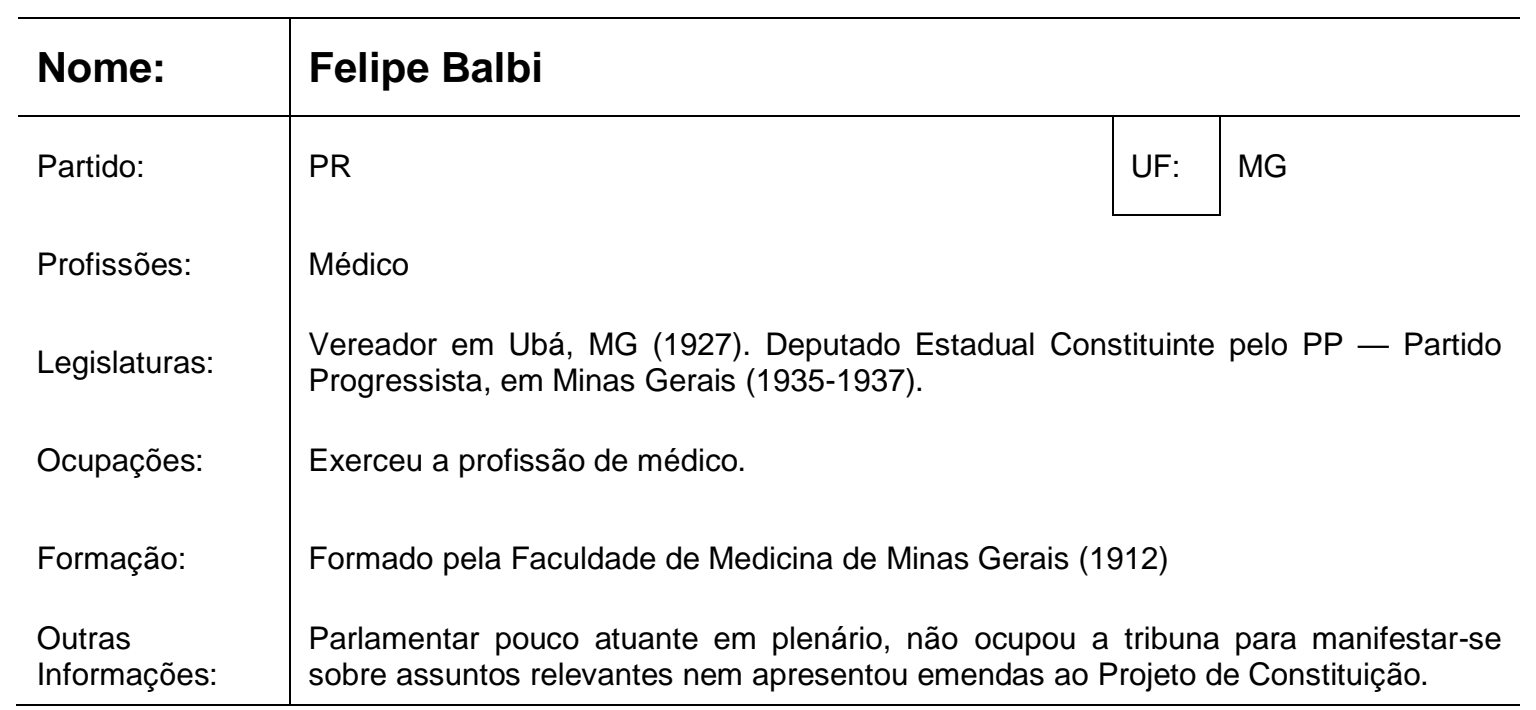


020

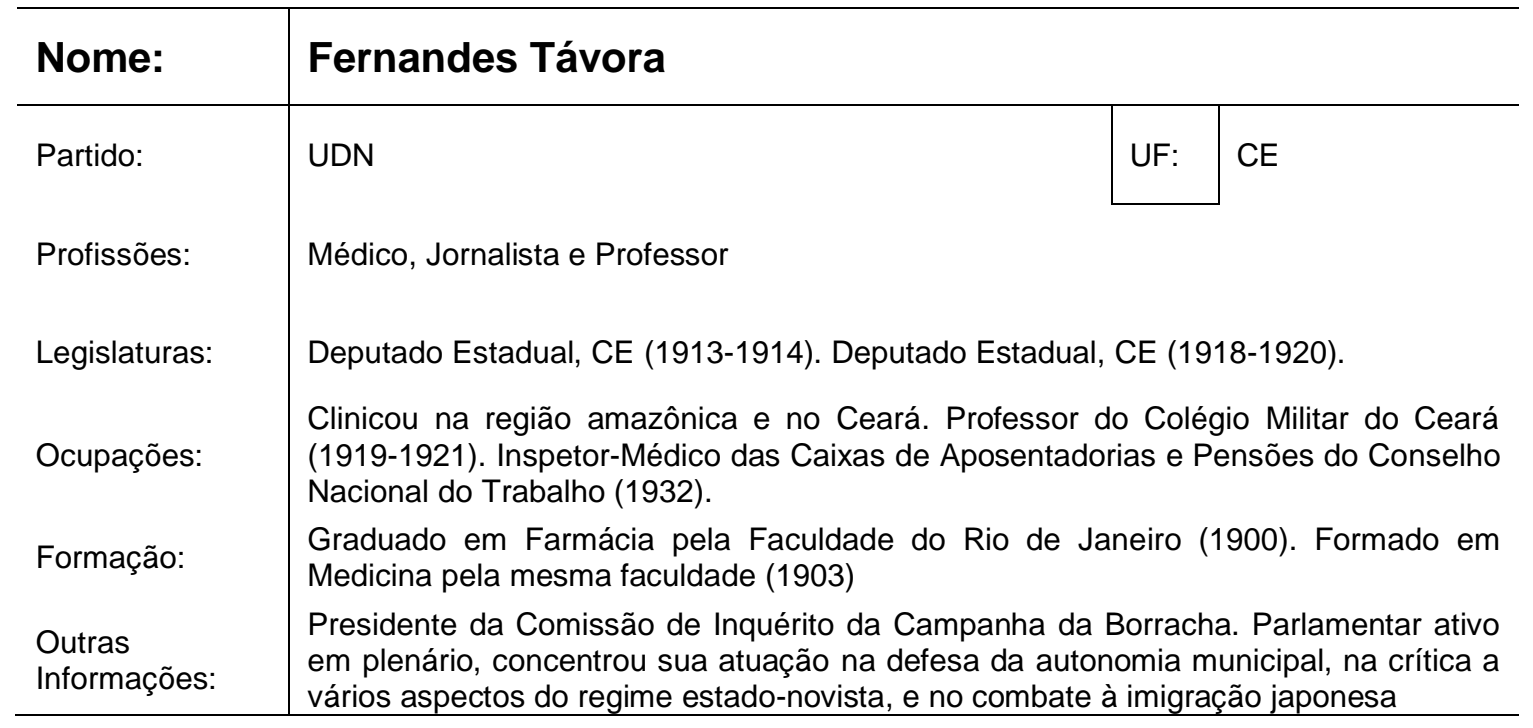

021

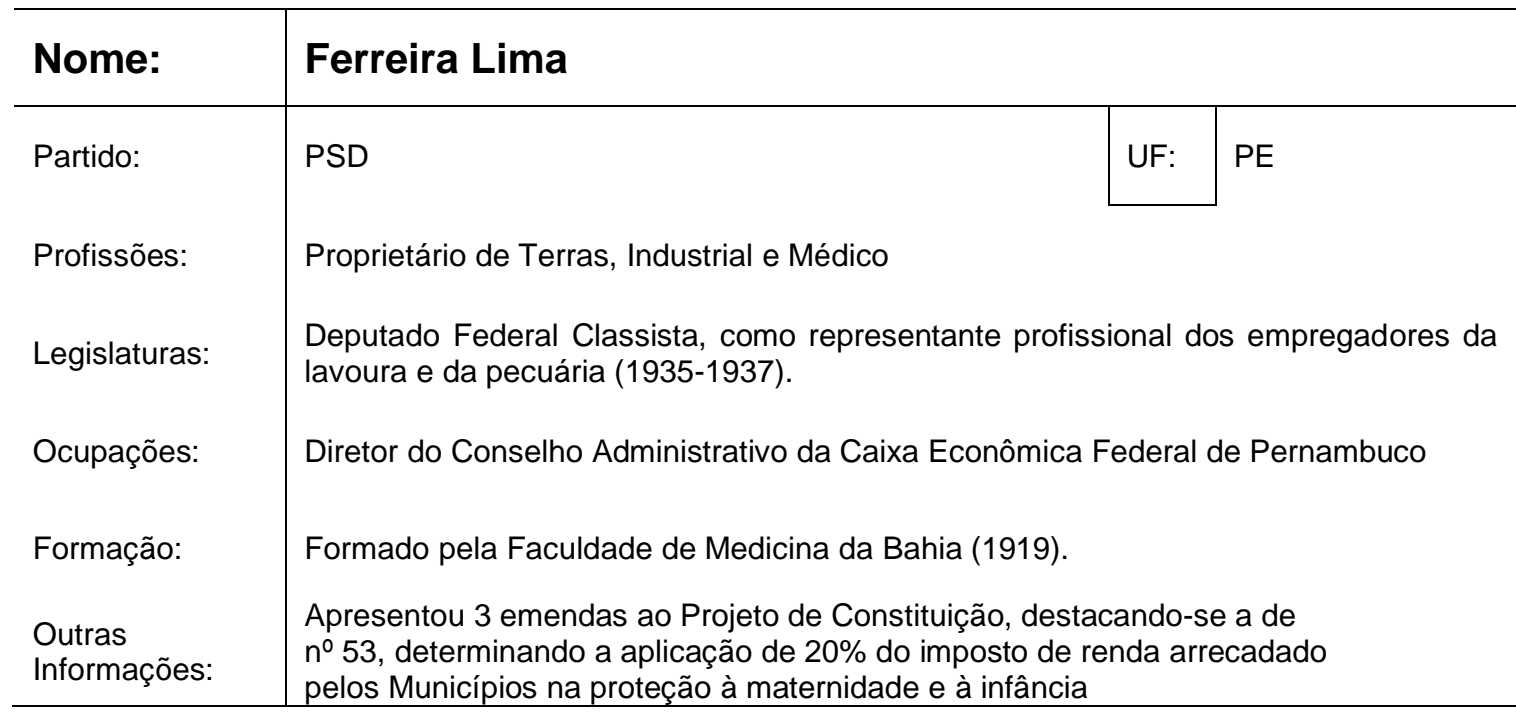

022

\begin{tabular}{l|l|l|l}
\hline Nome: & \multicolumn{2}{l}{ Fontes Romero } & \\
\hline Partido: & PSD & UF: DF \\
Profissões: & Médico & \\
Legislaturas: & Formado pela Escola de Medicina e Cirurgia do Rio de Janeiro (1937). \\
\cline { 2 - 3 } &
\end{tabular}




\begin{tabular}{|c|c|}
\hline Ocupações: & $\begin{array}{l}\text { Diretor-Técnico da Casa de Saúde e Maternidade Nossa Senhora da Penha (1937- } \\
\text { 1945). }\end{array}$ \\
\hline Formação: & Primeira legislatura. \\
\hline $\begin{array}{l}\text { Outras } \\
\text { Informações: }\end{array}$ & $\begin{array}{l}\text { Concentrou sua atuação na defesa da autonomia do Distrito Federal e na abordagem } \\
\text { de questões referentes à política local do Município do Rio de Janeiro }\end{array}$ \\
\hline
\end{tabular}

\section{3}

\begin{tabular}{l|l|l|l}
\hline Nome: & Frois da Mota & UF: & BA \\
\hline Partido: & PSD & Proprietário de Terras e Médico \\
Profissões: & Primeira legislatura. \\
Legislaturas: & Prefeito de Feira de Santana, Bahia (1944-1945). \\
Ocupações: & $\begin{array}{l}\text { Formado pela Faculdade de Medicina da Bahia (1921) } \\
\text { Concentrou-se na defesa da exploração do petróleo na Bahia e na remessa à Mesa } \\
\text { da Assembléia de requerimentos e indicações solicitando a feitura de obras no } \\
\text { interior de seu estado }\end{array}$ \\
\hline $\begin{array}{l}\text { Formação: } \\
\text { Outras }\end{array}$ &
\end{tabular}

\section{4}

\begin{tabular}{|c|c|c|c|}
\hline Nome: & \multicolumn{3}{|c|}{ Janduí Carneiro } \\
\hline Partido: & PSD & UF: & PB \\
\hline Profissões: & \multicolumn{3}{|c|}{ Médico } \\
\hline Legislaturas: & \multicolumn{3}{|c|}{ Primeira legislatura } \\
\hline Ocupações: & \multicolumn{3}{|c|}{ Exerceu a profissão de médico na Paraíba. } \\
\hline Formação: & \multicolumn{3}{|c|}{$\begin{array}{l}\text { Formado pela Faculdade Nacional de Medicina da Universidade do Rio de Janeiro, } \\
\text { DF (1926) }\end{array}$} \\
\hline $\begin{array}{l}\text { Outras } \\
\text { Informações: }\end{array}$ & \multicolumn{3}{|c|}{$\begin{array}{l}\text { Um dos parlamentares mais conservadores da Assembléia, concentrou sua atuação } \\
\text { na abordagem de questões referentes ao problema da saúde pública e no combate } \\
\text { furibundo à existência legal do MUT - Movimento Unificador dos Trabalhadores. }\end{array}$} \\
\hline
\end{tabular}


025

\begin{tabular}{|c|c|c|c|}
\hline Nome: & \multicolumn{3}{|c|}{ João Abdala } \\
\hline Partido: & PSD & UF: & SP \\
\hline Profissões: & \multicolumn{3}{|c|}{ Industrial, Proprietário de Terras e Médico } \\
\hline Legislaturas: & \multicolumn{3}{|c|}{ Vereador e Presidente da Câmara Municipal em Birigui, SP (1935-1937). } \\
\hline Ocupações: & \multicolumn{3}{|c|}{ Foi nomeado Prefeito de Birigui pelo Interventor Ademar de Barros } \\
\hline Formação: & \multicolumn{3}{|c|}{ Formado pela Faculdade Nacional de Medicina do Rio de Janeiro, DF (1927) } \\
\hline $\begin{array}{l}\text { Outras } \\
\text { Informações: }\end{array}$ & \multicolumn{3}{|c|}{ Parlamentar pouco atuante em plenário, não apresentou nenhum projeto. } \\
\hline
\end{tabular}

026

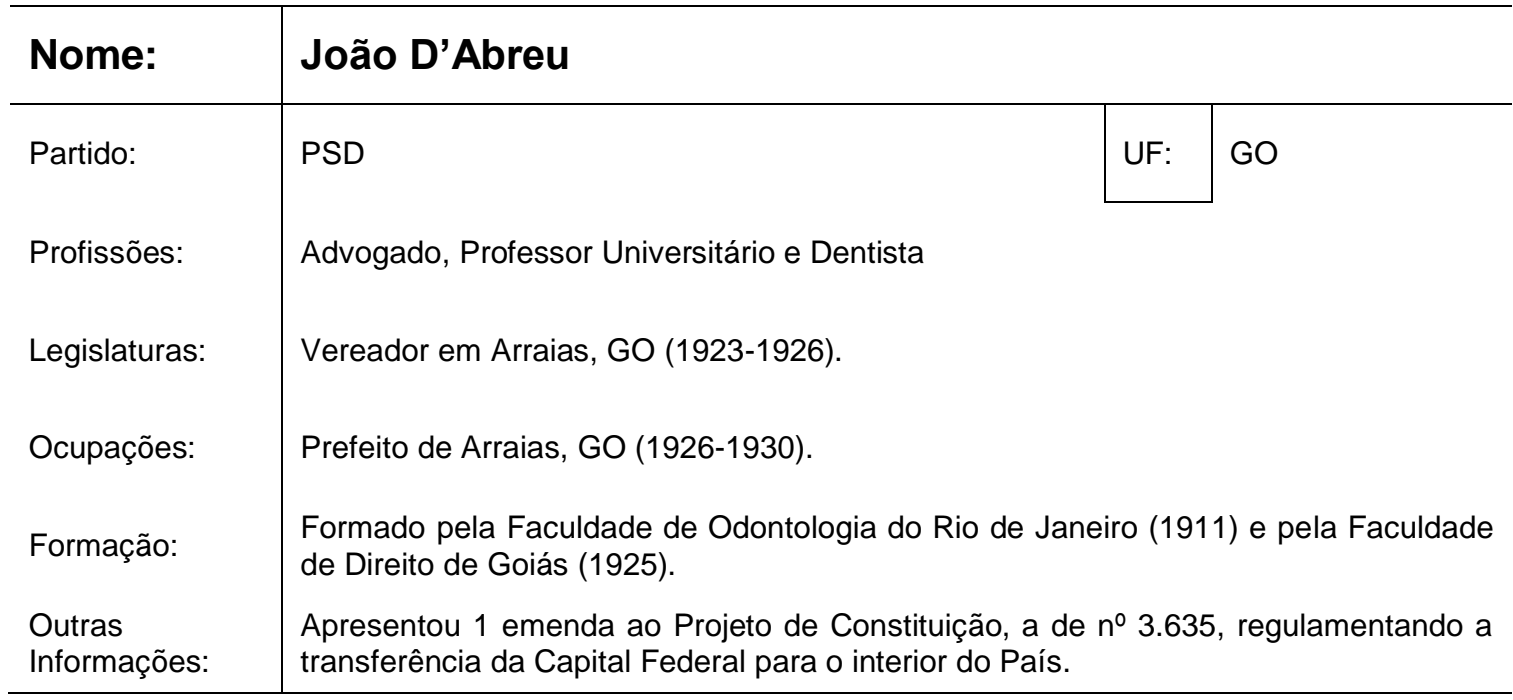

\section{7}

\begin{tabular}{l|l|l|l}
\hline Nome: & João Henrique & UF: & MG \\
\hline Partido: & PSD & Proprietário de Terras e Médico \\
Profissões: & $\begin{array}{l}\text { Vereador e Prefeito de Uberaba, MG (1923-1926). Deputado Estadual, PRM (1927- } \\
\text { 1930). Deputado Federal na legenda do PP - Partido Progressista (1935-1937). }\end{array}$ \\
\cline { 2 - 3 } & \multicolumn{2}{l}{}
\end{tabular}




\begin{tabular}{l|l}
\cline { 2 - 2 } Ocupações: & $\begin{array}{l}\text { Exerceu a profissão de médico em Uberaba, MG. Foi também pecuarista } \\
\text { na região do Triângulo mineiro. }\end{array}$ \\
Formação: & $\begin{array}{l}\text { Formado pela Faculdade Nacional de Medicina do Rio de Janeiro, DF (1917) } \\
\begin{array}{l}\text { Apresentou 1 emenda ao Projeto de Constituição, a de no } 395, \text { que } \\
\text { Informações: }\end{array}\end{array}$ \\
\hline $\begin{array}{l}\text { criava dispositivo assegurando assistência médica, dentária e farmacêutica a } \\
\text { todos os brasileiros. }\end{array}$
\end{tabular}

028

\begin{tabular}{|c|c|c|c|}
\hline Nome: & \multicolumn{3}{|c|}{ Joaquim Libânio } \\
\hline Partido: & PSD & UF: & $M G$ \\
\hline Profissões: & \multicolumn{3}{|c|}{ Proprietário de Terras, Médico e Empresário } \\
\hline Legislaturas: & \multicolumn{3}{|c|}{ Primeira legislatura. } \\
\hline Ocupações: & \multicolumn{3}{|c|}{$\begin{array}{l}\text { Foi Presidente da Companhia Mogiana de Estradas de Ferro, Diretor } \\
\text { do Banco Mercantil de São Paulo e fazendeiro nos Estados de Minas Gerais } \\
\text { e São Paulo. }\end{array}$} \\
\hline Formação: & \multicolumn{3}{|c|}{ Formado em Medicina (1916). } \\
\hline $\begin{array}{l}\text { Outras } \\
\text { Informações: }\end{array}$ & \multicolumn{3}{|c|}{$\begin{array}{l}\text { Parlamentar pouco atuante em plenário, não ocupou a tribuna para manifestar-se } \\
\text { sobre assuntos relevantes, nem apresentou emendas ao Projeto de Constituição. }\end{array}$} \\
\hline
\end{tabular}

\section{9}

\begin{tabular}{|c|c|c|c|}
\hline Nome: & \multicolumn{3}{|c|}{ José Cândido } \\
\hline Partido: & UDN & UF: & $\mathrm{Pl}$ \\
\hline Profissões: & \multicolumn{3}{|c|}{ Médico } \\
\hline Legislaturas: & \multicolumn{3}{|c|}{ Primeira legislatura. } \\
\hline Ocupações: & \multicolumn{3}{|c|}{ Chefe do Serviço de Clínica Tisiológica do Hospital Getúlio Vargas, no Piauí. } \\
\hline Formação: & \multicolumn{3}{|c|}{ Formado pela Faculdade de Medicina da Bahia (1939). } \\
\hline $\begin{array}{l}\text { Outras } \\
\text { Informações: }\end{array}$ & \multicolumn{3}{|c|}{$\begin{array}{l}\text { Concentrou sua atuação na abordagem de questões referentes à política regional do } \\
\text { Piauí. }\end{array}$} \\
\hline
\end{tabular}


030

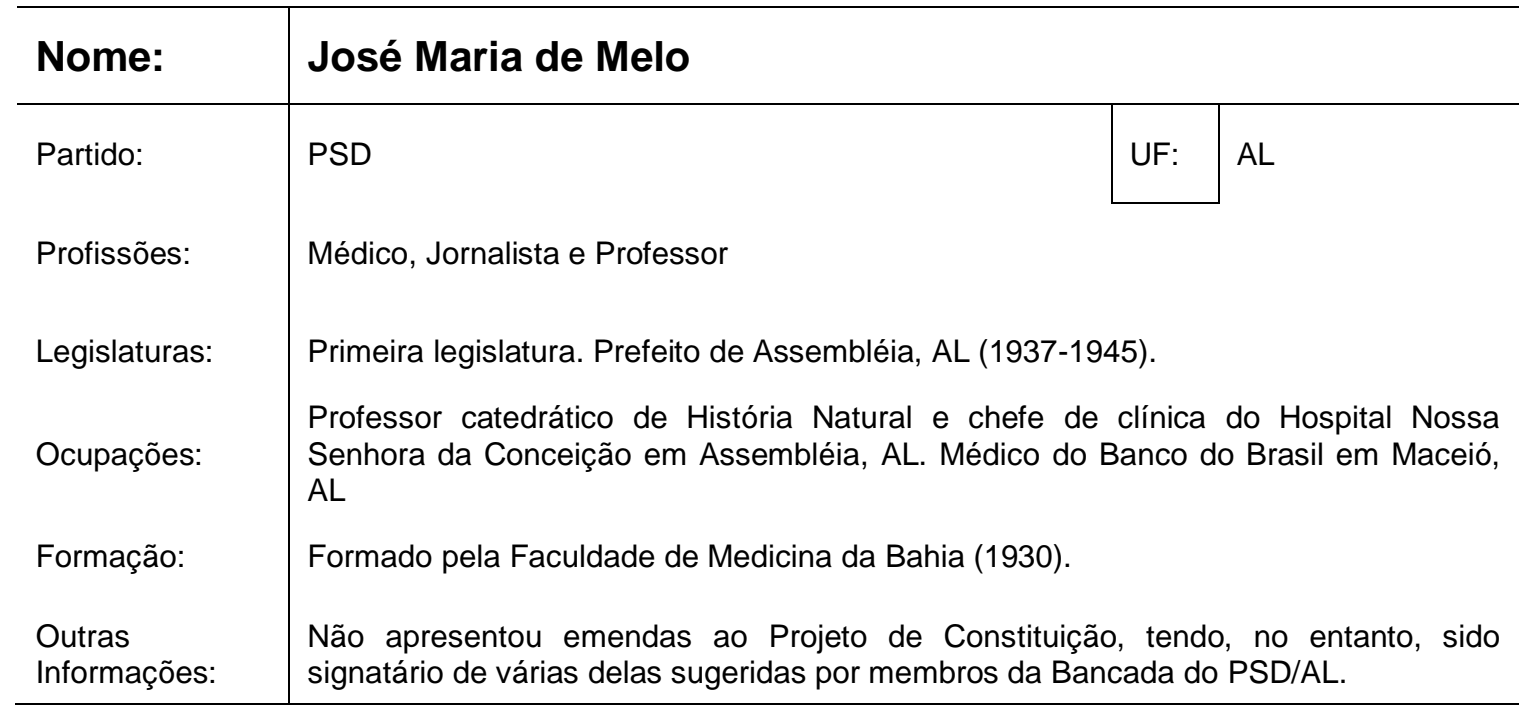

031

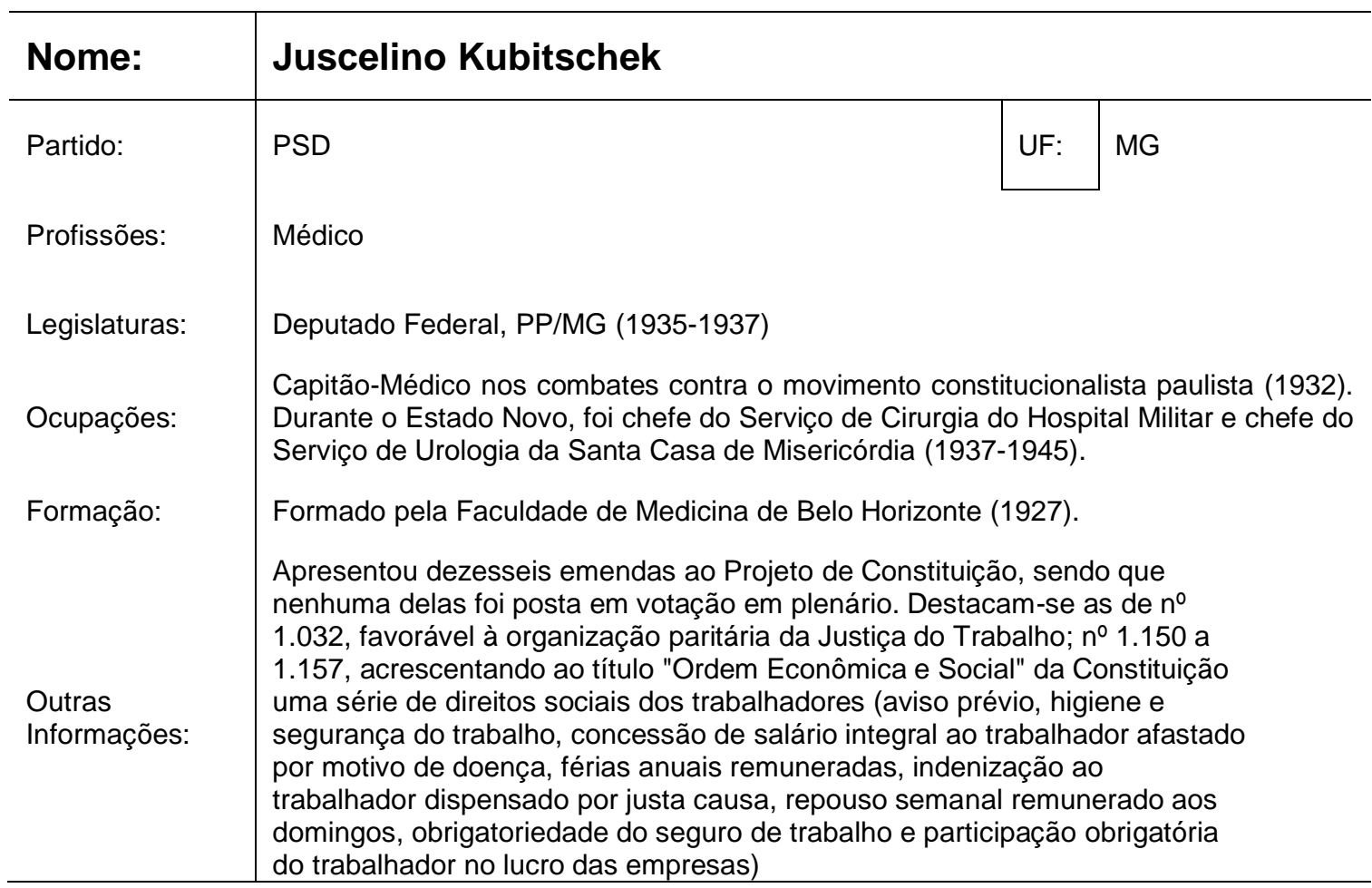

032

\begin{tabular}{l|l|l|l}
\hline Nome: & Leão Sampaio & \multicolumn{3}{|l}{} \\
\hline Partido: & UDN & UF: & CE \\
\cline { 2 - 4 }
\end{tabular}




\begin{tabular}{l|l}
\cline { 2 - 2 } $\begin{array}{l}\text { Profissões: } \\
\text { Legislaturas: }\end{array}$ & Médico \\
Ocupações: & Diretor do Posto Médico de Profilaxia Rural. \\
Formação: & $\begin{array}{l}\text { Formado pela Faculdade de Medicina do Rio de Janeiro, DF (1921) } \\
\text { Apresentou 22 emendas ao Projeto de Constituição. Destacam-se as } \\
\text { de no 133 (parcialmente aprovada; XXIII, 327), incluindo dispositivo } \\
\text { destinando 1\% das receitas tributárias da União, Estados e Municípios para } \\
\text { o amparo à maternidade e à infância em todo o território nacional; } n \text { no 1.741 } \\
\text { (aprovada; XXII, 66). }\end{array}$ \\
\hline \begin{tabular}{l} 
Informações: \\
\hline
\end{tabular}
\end{tabular}

\section{3}

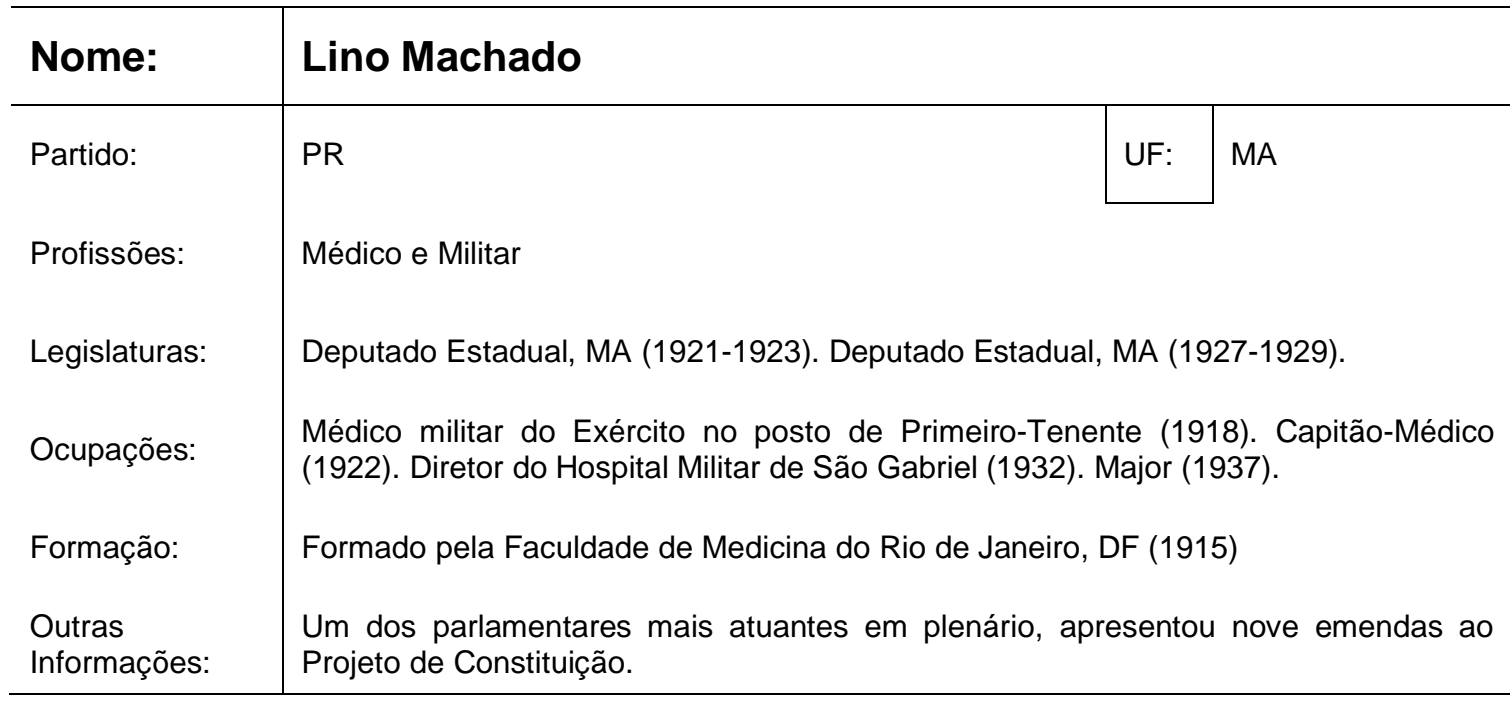

\section{4}

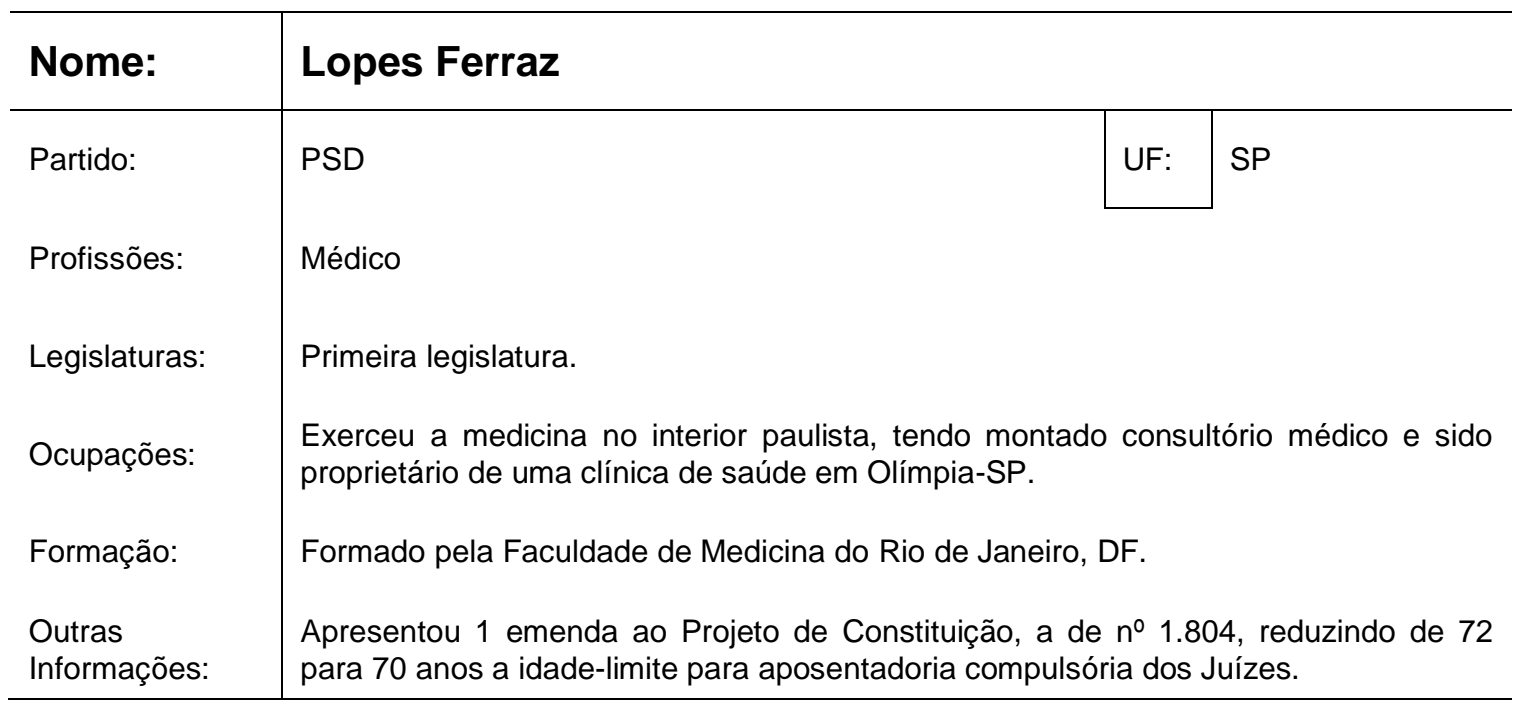


035

\begin{tabular}{l|l|l|l}
\hline Nome: & Manuel Novaes & UF: & BA \\
\hline Partido: & UDN & Médico & \multicolumn{2}{l}{} \\
Profissões: & $\begin{array}{l}\text { Deputado Constituinte e Federal, PSD/BA (1933-1935). Deputado Federal, PSD/BA } \\
\text { (1935-1937). } \\
\text { Legislaturas: }\end{array}$ & $\begin{array}{l}\text { Médico da Saúde Pública na Bahia, a partir de 1931. } \\
\text { Ocupações: }\end{array}$ & $\begin{array}{l}\text { Formado pela Faculdade de Medicina da Bahia (1930) } \\
\text { Formação: }\end{array}$ \\
Sobresentou 2 emendas ao Projeto de Constituição, sobre o Rio São Francisco e e \\
Informações:
\end{tabular}

036

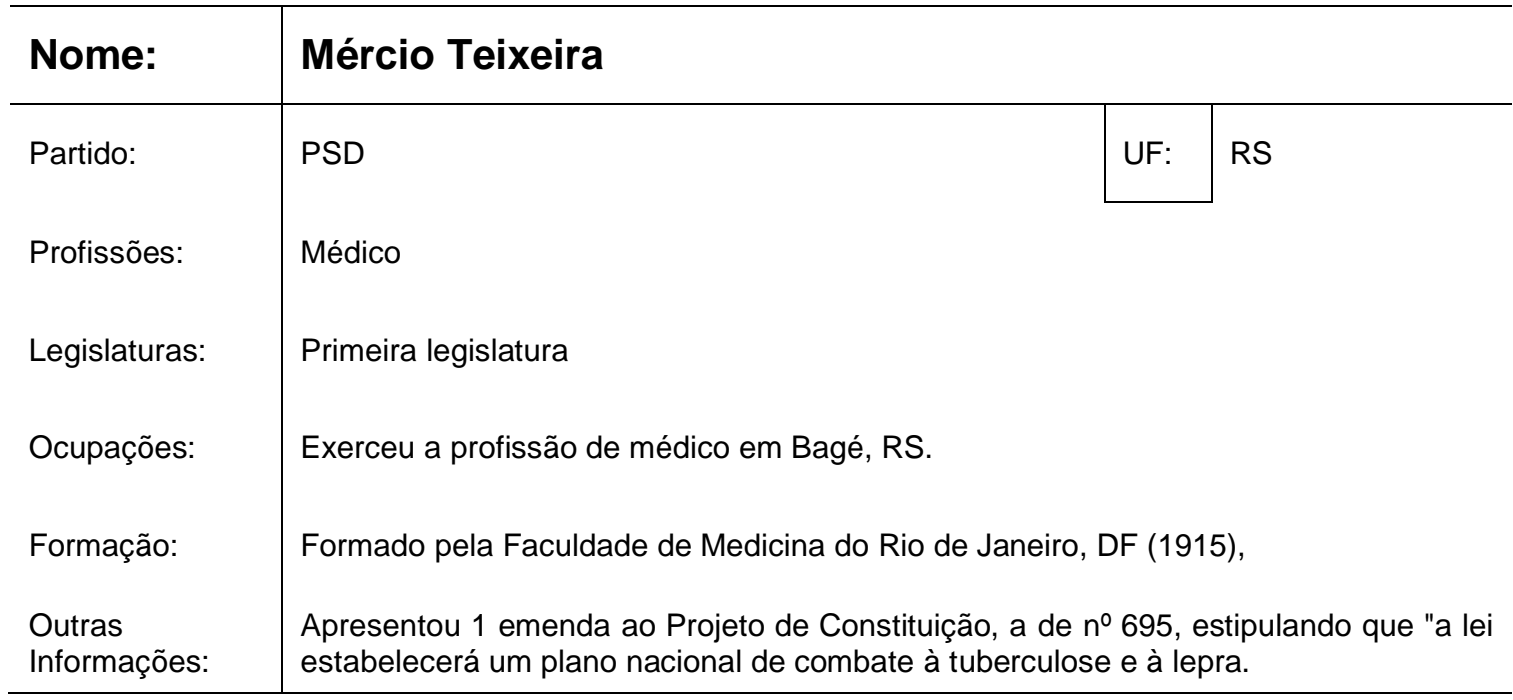

\section{7}

\begin{tabular}{l|l|l|l}
\hline Nome: & Miguel Couto & UF: & RJ \\
\hline Partido: & PSD & Médico, Industrial e Professor Universitário \\
Profissões: & $\begin{array}{l}\text { Vereador e Vice-Prefeito de Cabo Frio, RJ (sem data). Deputado Estadual, RJ (1935- } \\
1937) .\end{array}$ \\
\cline { 2 - 3 } &
\end{tabular}




\begin{tabular}{|c|c|}
\hline & $\begin{array}{l}\text { Foi professor da cadeira de Doenças Tropicais e Infecciosas, assistente de Clínica } \\
\text { Médica e auxiliar-preparador da cadeira de Anatomia Cirúrgica da Universidade do } \\
\text { Rio de Janeiro }\end{array}$ \\
\hline & aculdade de Medicina da Universidade do Rio de Janeiro, DF (1921). \\
\hline utro & $\begin{array}{l}\text { Concentrou sua atuação no combate veemente à imigração japonesa e na } \\
\text { abordagem de questões referentes aos problemas da saúde pública e da fixação do } \\
\text { "homem do campo" no interior do País. }\end{array}$ \\
\hline
\end{tabular}

038

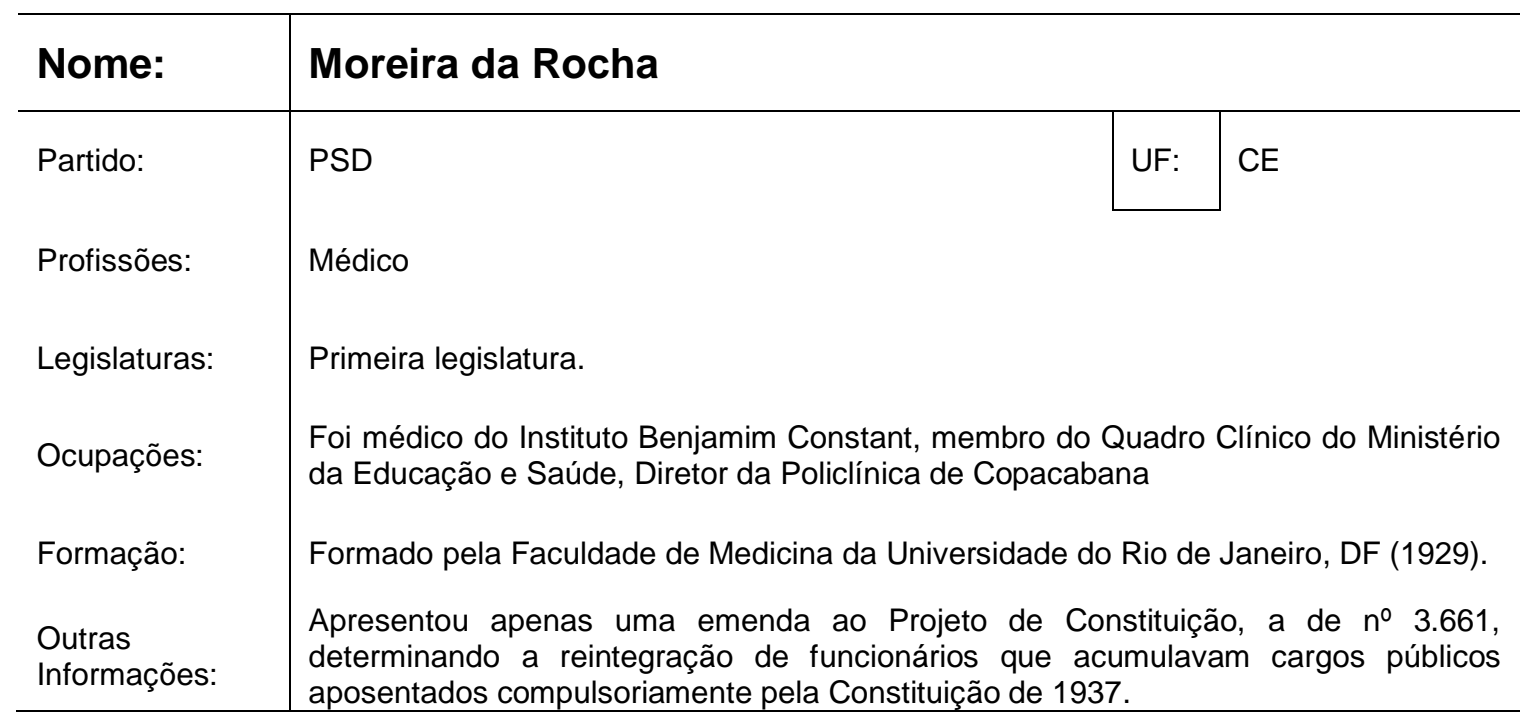

039

\begin{tabular}{|c|c|c|}
\hline \multirow{2}{*}{$\begin{array}{l}\text { Nome: } \\
\text { Partido: }\end{array}$} & \multicolumn{2}{|l|}{ Novelli Júnior } \\
\hline & PSD & SP \\
\hline Profissões: & \multicolumn{2}{|l|}{ Médico, Advogado e Professor } \\
\hline Legislaturas: & \multicolumn{2}{|l|}{ Primeira legislatura. } \\
\hline Ocupações: & \multicolumn{2}{|c|}{$\begin{array}{l}\text { Exerceu a medicina em Itu, SP, no início da década de 1930. Professor de Sociologia } \\
\text { na Escola Normal Nossa Senhora do Patrocínio, em Itu (1934). }\end{array}$} \\
\hline Formação: & \multicolumn{2}{|l|}{ Formado pela Faculdade de Medicina do Rio de Janeiro, DF (1931). } \\
\hline $\begin{array}{l}\text { Outras } \\
\text { Informações: }\end{array}$ & \multicolumn{2}{|c|}{$\begin{array}{l}\text { Apresentou } 2 \text { emendas ao Projeto de Constituição, destacando-se a de } \\
\mathrm{n}^{\circ} 1.905 \text {, acrescentando as "estâncias sanitárias" ao leque de Municípios a } \\
\text { terem seus prefeitos nomeados por autoridades superiores, e não eleitos } \\
\text { diretamente. }\end{array}$} \\
\hline
\end{tabular}


040

\begin{tabular}{|c|c|c|c|}
\hline \multirow{2}{*}{$\begin{array}{l}\text { Nome: } \\
\text { Partido: }\end{array}$} & \multicolumn{3}{|c|}{ Odilon Soares } \\
\hline & PSD & UF: & MA \\
\hline Profissões: & \multicolumn{3}{|c|}{ Médico e Professor } \\
\hline Legislaturas: & \multicolumn{3}{|c|}{ Primeira legislatura. } \\
\hline Ocupações: & \multicolumn{3}{|c|}{ Cirurgião da Santa Casa e chefe de clínica cirúrgica em hospitais maranhenses. } \\
\hline Formação: & \multicolumn{3}{|c|}{$\begin{array}{l}\text { Formado pela Faculdade de Medicina da Universidade do Brasil, Rio de Janeiro, DF } \\
\text { (1928) }\end{array}$} \\
\hline $\begin{array}{l}\text { Outras } \\
\text { Informações: }\end{array}$ & \multicolumn{3}{|c|}{$\begin{array}{l}\text { Não apresentou projetos, apenas remessa à Mesa da Assembléia da Indicação no } 36 \\
\text { sugerindo ao Poder Executivo a necessidade urgente da criação de uma cadeira de } \\
\text { Tisiologia nas faculdades de Medicina do País. }\end{array}$} \\
\hline
\end{tabular}

041

\begin{tabular}{l|l|l|l}
\hline Nome: & Olinto Fonseca \\
\hline Partido: & PSD & UF: & MG \\
Profissões: & Médico e Jornalista & Pegislaturas: & $\begin{array}{l}\text { Primeira legislatura. } \\
\text { Médico da Força Pública de Minas Gerais e assistente de Clínica Urológica do } \\
\text { Hospital Militar (1934). Exerceu o jornalismo em diversos periódicos na imprensa } \\
\text { mineira. }\end{array}$ \\
Ocupações: & $\begin{array}{l}\text { Formado pela Faculdade de Medicina de Belo Horizonte, MG } \\
\text { Formação: }\end{array}$ & $\begin{array}{l}\text { Apresentou três emendas ao Projeto de Constituição, destacando-se a de no 507, } \\
\text { estipulando que "a maternidade, a infância e a adolescência serão objeto de proteção } \\
\text { especial }\end{array}$ \\
Outras \\
Informações:
\end{tabular}

042

\begin{tabular}{l|l|l|l}
\hline Nome: & \multicolumn{2}{l}{ Raul Pilla } & \multicolumn{2}{l}{} \\
\hline Partido: & PL & UF: & RS \\
Profissões: & Médico, Professor Universitário e Jornalista & \\
Legislaturas: & \multicolumn{2}{l}{ Deputado Estadual Constituinte na legenda do PL (1935-1937). } \\
\cline { 2 - 3 }
\end{tabular}




\begin{tabular}{|c|c|}
\hline Ocupações: & $\begin{array}{l}\text { Livre-docente de Fisiologia na Faculdade de Medicina de Porto Alegre (1924) e } \\
\text { professor titular de Fisiologia na mesma faculdade (1926). }\end{array}$ \\
\hline ormação: & Formado pela Faculdade de Medicina de Porto Alegre, RS (1915) \\
\hline $\begin{array}{l}\text { Outras } \\
\text { Informações: }\end{array}$ & $\begin{array}{l}\text { Apresentou } 16 \text { emendas ao Projeto de Constituição, principalmente } \\
\text { aos dispositivos que regulamentavam o funcionamento das instituições } \\
\text { representativas. }\end{array}$ \\
\hline
\end{tabular}

\section{3}

\begin{tabular}{|c|c|c|}
\hline Nome: & \multicolumn{2}{|l|}{ Régis Pacheco } \\
\hline Partido: & PSD & BA \\
\hline Profissões: & \multicolumn{2}{|l|}{ Médico } \\
\hline Legislaturas: & \multicolumn{2}{|c|}{$\begin{array}{l}\text { Vereador e Presidente do Conselho Municipal de Vitória da Conquista, Bahia } \\
\text { (1934-1937). }\end{array}$} \\
\hline Ocupações: & \multicolumn{2}{|c|}{$\begin{array}{l}\text { Após formar-se, exerceu a medicina em Salvador, Bahia, tendo sido proprietário de } \\
\text { uma clínica nesta cidade. }\end{array}$} \\
\hline Formação: & \multirow{2}{*}{\multicolumn{2}{|c|}{$\begin{array}{l}\text { Formado pela Faculdade de Medicina da Bahia (1919). } \\
\text { Apresentou } 6 \text { emendas ao Projeto de Constituição, destacando-se a de no } 366 \text {, } \\
\text { concedendo personalidade jurídica ao agrupamento de Municípios de uma mesma } \\
\text { região, objetivando explorar determinada atividade econômica, e a de no } 387 \text {, } \\
\text { regulamentando a concessão do direito de asilo. }\end{array}$}} \\
\hline $\begin{array}{l}\text { Outras } \\
\text { Informações: }\end{array}$ & & \\
\hline
\end{tabular}

\section{4}

\begin{tabular}{l|l|l|l}
\hline Nome: & Romão Júnior & UF: & RJ \\
\hline Partido: & UDN & Médico & \\
Profissões: & Vereador e Prefeito de Petrópolis, RJ. \\
Legislaturas: & Exerceu a profissão de médico no RJ. \\
Ocupações: & $\begin{array}{l}\text { Formado pela Faculdade de Medicina do Rio de Janeiro, DF (1916) } \\
\text { Parlamentar pouco atuante em plenário, concentrou-se na apresentação de emendas } \\
\text { Formação: } \\
\text { municipal da cidade de Petrópolis, RJ. }\end{array}$ \\
$\begin{array}{l}\text { Outras } \\
\text { Informações: }\end{array}$ & \multicolumn{2}{l|l}{ política } \\
\hline
\end{tabular}


045

\begin{tabular}{l|l|l|l}
\hline Nome: & \multicolumn{2}{|l}{ Rui Santos } \\
\hline Partido: & UDN & UF: & BA \\
Profissões: & Médico, Professor e Escritor \\
Legislaturas: & $\begin{array}{l}\text { Primeira legislatura. } \\
\text { Foi fazendeiro em Feira de Santana, BA, e professor da Faculdade de Medicina da } \\
\text { Bahia. }\end{array}$ \\
Ocupações: & $\begin{array}{l}\text { Formado pela Faculdade de Medicina da Bahia (1928). } \\
\text { Formação: }\end{array}$ \\
$\begin{array}{l}\text { Outras } \\
\text { Informações: }\end{array}$ & $\begin{array}{l}\text { Trabalhou na questão social (educação, saúde e habitação) e referentes a problemas } \\
\text { regionais de seu estado }\end{array}$ \\
\hline
\end{tabular}

046

\begin{tabular}{|c|c|c|c|}
\hline Nome: & Sigefredo Pacheco & & \\
\hline Partido: & PSD & UF: & $\mathrm{PI}$ \\
\hline Profissões: & \multicolumn{3}{|l|}{ Médico, Proprietário de Terras e Professor Universitário } \\
\hline Legislaturas: & & & \\
\hline Ocupações: & \multicolumn{3}{|c|}{$\begin{array}{l}\text { Professor de Histologia da Faculdade Fluminense de Medicina, farmacêutico e oficial } \\
\text { de reserva do Corpo Médico do Exército, no Piauí. }\end{array}$} \\
\hline Formação: & \multicolumn{3}{|c|}{$\begin{array}{l}\text { Formado pela Faculdade de Farmácia (1927) e pela Faculdade de Medicina do Rio } \\
\text { de Janeiro (1930). }\end{array}$} \\
\hline $\begin{array}{l}\text { Outras } \\
\text { Informações: }\end{array}$ & \multicolumn{3}{|c|}{ Atuou apenas tomando parte nos debates sobre a política do Piauí. } \\
\hline
\end{tabular}

\section{7}

\begin{tabular}{l|l|l|l}
\hline Nome: & \multicolumn{2}{l}{ Silvio de Campos } & \multicolumn{2}{l}{} \\
\hline Partido: & PSD & UF: & SP \\
Profissões: & Médico & & \\
\cline { 2 - 3 }
\end{tabular}




\begin{tabular}{|c|c|}
\hline Legislaturas: & Deputado Federal (1881-1893) \\
\hline Ocupações: & Foi Promotor Público e Curador Fiscal das Massas Falidas em São Paulo. \\
\hline Formação: & Formado pela Faculdade de Direito de São Paulo, SP (1903). \\
\hline $\begin{array}{l}\text { Outras } \\
\text { Informações: }\end{array}$ & $\begin{array}{l}\text { Parlamentar pouco atuante, embora participando de várias articulações } \\
\text { políticas fora do plenário. }\end{array}$ \\
\hline
\end{tabular}

048

\begin{tabular}{|c|c|c|c|}
\hline \multirow{2}{*}{$\begin{array}{l}\text { Nome: } \\
\text { Partido: }\end{array}$} & \multicolumn{3}{|c|}{ Teódulo de Albuquerque } \\
\hline & PPS & UF: & $\mathrm{BA}$ \\
\hline Profissões: & \multicolumn{3}{|c|}{ Médico } \\
\hline Legislaturas: & \multicolumn{3}{|c|}{ Primeira legislatura. } \\
\hline Ocupações: & \multicolumn{3}{|c|}{ Exerceu a medicina e foi inspetor federal de Educação na Bahia. } \\
\hline Formação: & \multicolumn{3}{|c|}{ Formado pela Faculdade de Medicina da Bahia (1939). } \\
\hline $\begin{array}{l}\text { Outras } \\
\text { Informações: }\end{array}$ & \multicolumn{3}{|c|}{$\begin{array}{l}\text { Apresentou } 4 \text { emendas ao Projeto de Constituição, destacando-se a de } \\
\text { no }^{0} 1.720 \text {, obrigando a União a executar um Plano de Valorização Econômica } \\
\text { do Rio São Francisco. }\end{array}$} \\
\hline
\end{tabular}

049

\begin{tabular}{|c|c|c|c|}
\hline \multirow{2}{*}{$\begin{array}{l}\text { Nome: } \\
\text { Partido: }\end{array}$} & \multicolumn{3}{|c|}{ Sen. Alfredo Neves } \\
\hline & PSD & UF: & RJ \\
\hline Profissões: & \multicolumn{3}{|c|}{ Médico, Professor Universitário e Jornalista } \\
\hline Legislaturas: & \multicolumn{3}{|c|}{ Deputado Estadual, RJ (1923-1926). Deputado Estadual, RJ (192 } \\
\hline Ocupações: & \multicolumn{3}{|c|}{$\begin{array}{l}\text { Secretário Estadual na gestão do Interventor Amaral Peixoto (1937-1939); Presidente } \\
\text { do Conselho Administrativo do Rio de Janeiro (1940-1945). }\end{array}$} \\
\hline Formação: & \multicolumn{3}{|c|}{ Formado pela Faculdade de Medicina do Rio de Janeiro, DF (1912). } \\
\hline $\begin{array}{l}\text { Outras } \\
\text { Informações: }\end{array}$ & \multicolumn{3}{|c|}{ Foi Presidente da Comissão de Investigação Econômica e Social. } \\
\hline
\end{tabular}


050

\begin{tabular}{l|l|l|l}
\hline Nome: & \multicolumn{2}{|l}{ Sen. Durval Cruz } & \multicolumn{2}{l}{} \\
\hline Partido: & PR & SE \\
Profissões: & Proprietário de Terras, Industrial e Médico & \\
\hline Legislaturas: & Primeira legislatura. \\
Ocupações: & Industrial e usineiro. \\
Formação: & Formado pela Faculdade de Medicina da Bahia (1924). \\
$\begin{array}{l}\text { Outras } \\
\text { Informações: }\end{array}$ & $\begin{array}{l}\text { Parlamentar pouco atuante em plenário, ocupou a tribuna para proferir discurso sobre } \\
\text { distribuição de rendas a favor dos Municípios }\end{array}$ \\
\hline
\end{tabular}

051

\begin{tabular}{|c|c|c|c|}
\hline \multirow{2}{*}{$\begin{array}{l}\text { Nome: } \\
\text { Partido: }\end{array}$} & \multicolumn{3}{|c|}{ Hamilton Nogueira } \\
\hline & UDN & UF: & DF \\
\hline Profissões: & \multicolumn{3}{|c|}{ Professor e Médico } \\
\hline Legislaturas: & \multicolumn{3}{|c|}{ Primeira legislatura. } \\
\hline Ocupações: & \multicolumn{3}{|c|}{ Livre-docente de Higiene na Faculdade de Medicina do Rio de Janeiro (1929). } \\
\hline Formação: & \multicolumn{3}{|c|}{ Formado pela Faculdade de Medicina do Rio de Janeiro, DF (1918). } \\
\hline $\begin{array}{l}\text { Outras } \\
\text { Informações: }\end{array}$ & \multicolumn{3}{|c|}{$\begin{array}{l}\text { Apresentou } 2 \text { emendas ao Projeto de Constituição: a de } n^{\circ}=1.087 \text {, assegurando o } \\
\text { ingresso de qualquer cidadão, sem distinção de cor, nas carreiras diplomáticas, } \\
\text { militares e civis; e a de no } 3.454 \text {, incluindo os empregados de todas as autarquias na } \\
\text { carreira do funcionalismo público. }\end{array}$} \\
\hline
\end{tabular}

\section{2}

\begin{tabular}{l|l|l|l}
\hline Nome: & Levindo Coelho & UF: & MG \\
\hline Partido: & PSD & & \\
Profissões: & Proprietário de Terras e Médico &
\end{tabular}




\begin{tabular}{|c|c|}
\hline Legislaturas: & $\begin{array}{l}\text { Vereador e Presidente da Câmara Municipal de Ubá, MG (1915-1917). Senador por } \\
\text { várias legislaturas consecutivas (1915-1930). Vereador } \\
\text { Municipal em Ubá (1918-1920). Deputado Federal, PRM (1930). }\end{array}$ \\
\hline Ocupações: & Professor da Escola de Farmácia de Ouro Preto (1895-1901). \\
\hline Formação: & Diplomado pela Escola de Farmácia de Ouro Preto, MG (1894) \\
\hline $\begin{array}{l}\text { Outras } \\
\text { nformações: }\end{array}$ & $\begin{array}{l}\text { Parlamentar pouco atuante em plenário, apenas ocupou a tribuna para proferir } \\
\text { discurso sobre o projeto constitucional. }\end{array}$ \\
\hline
\end{tabular}

053

\begin{tabular}{|c|c|c|c|}
\hline \multirow{2}{*}{$\begin{array}{l}\text { Nome: } \\
\text { Partido: }\end{array}$} & \multicolumn{3}{|c|}{ Pedro Ludovico Teixeira } \\
\hline & PSD & UF: & GO \\
\hline Profissões: & \multicolumn{3}{|c|}{ Proprietário de Terras, Banqueiro e Médico } \\
\hline Legislaturas: & \multicolumn{3}{|c|}{ Primeira legislatura. } \\
\hline Ocupações: & \multicolumn{3}{|c|}{ Exerceu a medicina no interior de Goiás. } \\
\hline Formação: & \multicolumn{3}{|c|}{ Formado pela Faculdade de Medicina do Rio de Janeiro, DF (1915) } \\
\hline $\begin{array}{l}\text { Outras } \\
\text { Informações: }\end{array}$ & \multicolumn{3}{|c|}{$\begin{array}{l}\text { Concentrou sua atuação na abordagem de questões referentes à política regional do } \\
\text { Estado de Goiás e na defesa da mudança da capital para a região central do País. }\end{array}$} \\
\hline
\end{tabular}

\section{4}

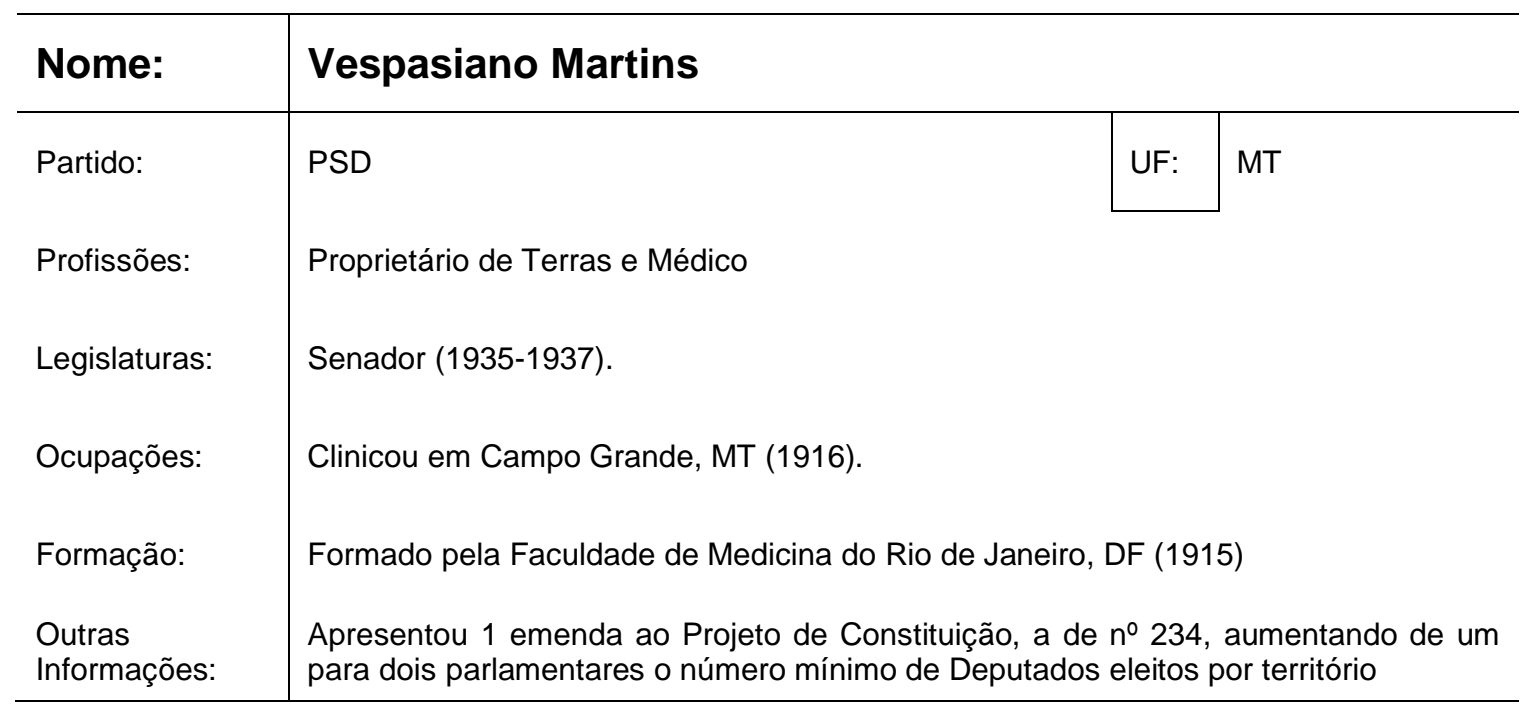


CONSTITUINTES DE 1987-88

DEPUTADOS:

001

\begin{tabular}{l|l|l|l}
\hline Nome: & \multicolumn{2}{|l}{ Abigail Feitosa } \\
\hline Partido: & PMDB - 1988 / PSB - 1988 & UF: & BA \\
Profissões: & MÉDICA \\
Legislaturas: & $1987-1991$ \\
Ocupações: & Médica do INAMPS no Hospital Ana Nery e da Secretaria do Estado da Bahia. \\
Formação: & $\begin{array}{l}\text { Medicina, UFBA, Salvador, 1951-1956. } \\
\text { Outras } \\
\text { Informações: }\end{array}$ & $\begin{array}{l}\text { ANC: Subcomissão de Saúde, Seguridade e do Meio Ambiente, da Comissão da } \\
\text { Ordem Social: Suplente, PSB, 1987; Comissão de Sistematização: Titular, PSB, } \\
\text { Coordenadora-Geral do Movimento de Unidade Popular-MUP, 1985. }\end{array}$ \\
\hline
\end{tabular}

002

\begin{tabular}{|c|c|c|c|}
\hline Nome: & \multicolumn{3}{|l|}{ Adolpho Barbosa Neto de Oliveira } \\
\hline Partido: & $\begin{array}{l}\text { PL; PMDB; UDN, 1947-1967; PDR, 1967-1973; MDB, } \\
\text { 1967-1974; PFL, 1990-. }\end{array}$ & UF: & RJ \\
\hline Profissões: & \multicolumn{3}{|l|}{ Médico } \\
\hline Legislaturas: & \multicolumn{3}{|l|}{ 1963-1967, 1967-1971, 1971-1975 e 1987-1991. } \\
\hline Ocupações: & \multicolumn{3}{|c|}{$\begin{array}{l}\text { Presidente, Instituto de Registro Imobiliário do Brasil, São Paulo, SP, 1984-1986; } \\
\text { Secretário de Administração Geral, Rio de Janeiro, RJ, 1955-1960. }\end{array}$} \\
\hline Formação: & \multicolumn{3}{|l|}{ Medicina, Univ. do Brasil, Rio de Janeiro, 1943-1948. } \\
\hline $\begin{array}{l}\text { Outras } \\
\text { Informações: }\end{array}$ & \multicolumn{3}{|c|}{$\begin{array}{l}\text { ANC: Subcomissão do Poder Judiciário e do Ministério Público, da Comissão da } \\
\text { Organização dos Poderes e Sistema de Governo: Suplente, } 1987 .\end{array}$} \\
\hline
\end{tabular}

003

\begin{tabular}{l|l|l|l}
\hline Nome: & \multicolumn{2}{l}{ Adylson Martins Motta } \\
\hline Partido: & PPR, -1995; ARENA; PSD; PDS; PPB, 1995-. & UF: & RS \\
\cline { 2 - 4 } &
\end{tabular}




\begin{tabular}{|c|c|}
\hline Profissões: & Cirurgião-Dentista e Bacharel em Direito \\
\hline Legislaturas: & 1987-1991, 1991-1995 e 1995-1999. \\
\hline Ocupações: & $\begin{array}{l}\text { Cirurgião-Dentista, Secretário da Presidência, 1961-1962, Diretor de Pessoal e } \\
\text { Diretor-Geral, 1968-1970, ALRS; Chefe de Gabinete do Instituto Gaúcho de Reforma } \\
\text { Agrária, RS, 1964-1965; Chefe de Gabinete e Secretário de Saúde e Meio Ambiente, } \\
\text { substituto, do Estado do Rio Grande do Sul, 1971-1978; Secretário de Estado Chefe } \\
\text { da Casa Civil do Governo do Rio Grande do Sul, 1983-1986; Ministro do Tribunal de } \\
\text { Contas da União, TCU, 1999. }\end{array}$ \\
\hline Formação: & Odontologia, PUC, Porto Alegre, RS, 1960; Direito, PUC, Porto Alegre, RS, 1976. \\
\hline $\begin{array}{l}\text { Outras } \\
\text { Informações: }\end{array}$ & $\begin{array}{l}\text { ANC: Comissão da Ordem Social: Segundo-Vice-Presidente, 1987; Comissão de } \\
\text { Sistematização: Suplente, 1987-1988; Subcomissão de Saúde, Seguridade e do Meio } \\
\text { Ambiente, da Comissão da Ordem Social: Titular, } 1987 .\end{array}$ \\
\hline
\end{tabular}

004

\begin{tabular}{|c|c|c|c|}
\hline \multirow{2}{*}{$\begin{array}{l}\text { Nome: } \\
\text { Partido: }\end{array}$} & \multicolumn{3}{|l|}{ Alarico Abib } \\
\hline & ARENA, 1968-1979; PP, 1980-1981; PMDB, 1982-. & UF: & PR \\
\hline Profissões: & \multicolumn{3}{|l|}{ Agropecuarista e Médico } \\
\hline Legislaturas: & \multicolumn{3}{|l|}{$1987-1991$} \\
\hline Ocupações: & \multicolumn{3}{|l|}{ NÃO INFORMADO } \\
\hline Formação: & \multirow{2}{*}{\multicolumn{3}{|c|}{$\begin{array}{l}\text { Medicina, UFPR, Curitiba, 1959-1964. } \\
\text { ANC: Subcomissão de Saúde, Seguridade e do Meio Ambiente, da Comissão da } \\
\text { Ordem Social: Titular, 1987; Subcomissão de Defesa do Estado, da Sociedade e de } \\
\text { sua Segurança, da Comissão da Organização Eleitoral, Partidária e Garantia das } \\
\text { Instituições: Suplente, } 1987 .\end{array}$}} \\
\hline $\begin{array}{l}\text { Outras } \\
\text { Informações: }\end{array}$ & & & \\
\hline
\end{tabular}

005

\begin{tabular}{l|l|l|l}
\hline Nome: & \multicolumn{2}{|l}{ Alceni Ângelo Guerra } \\
\hline Partido: & PDS, 1982-1985; PFL, 1985-2007; DEM, 2007-. & UF: & PR \\
Profissões: & Médico \\
Legislaturas: & $\begin{array}{l}\text { 1983-1987, 1987-1991 e 2007-2011. } \\
\text { Chefe dos Médicos Residentes, Hospital das Clínicas, PR, 1974; Ministro da Saúde, } \\
\text { 1990-1992; Ministro da Criança, 1991-1992; Chefe da Casa Civil do Governo do } \\
\text { Paraná, 2000-2002; Superintendente Regional, Instituto de Assistência Médica da } \\
\text { Previdência Social do Paraná, 1979-1982. }\end{array}$ \\
\cline { 2 - 2 }
\end{tabular}




\begin{tabular}{l|l}
\cline { 2 - 3 } Formação: & Medicina, UFPR, Curitiba, 1972; Pós-Graduação em Pediatria, UFPR, Curitiba, 1973- \\
& 1974; Curso de Aperfeiçoamento em Crescimento e Desenvolvimento, Univ. de \\
& Buenos Aires, 1975. \\
ANC: Subcomissão do Poder Legislativo, da Comissão da Organização dos Poderes \\
Informações: & $\begin{array}{l}\text { e Sistema de Governo: Suplente, 1987; Subcomissão dos Negros, Populações } \\
\text { Indígenas, Pessoas Deficientes e Minorias, da Comissão da Ordem Social: Relator, } \\
\text { 1987; Sistematização: Titular, 1987-1988. }\end{array}$ \\
\hline
\end{tabular}

006

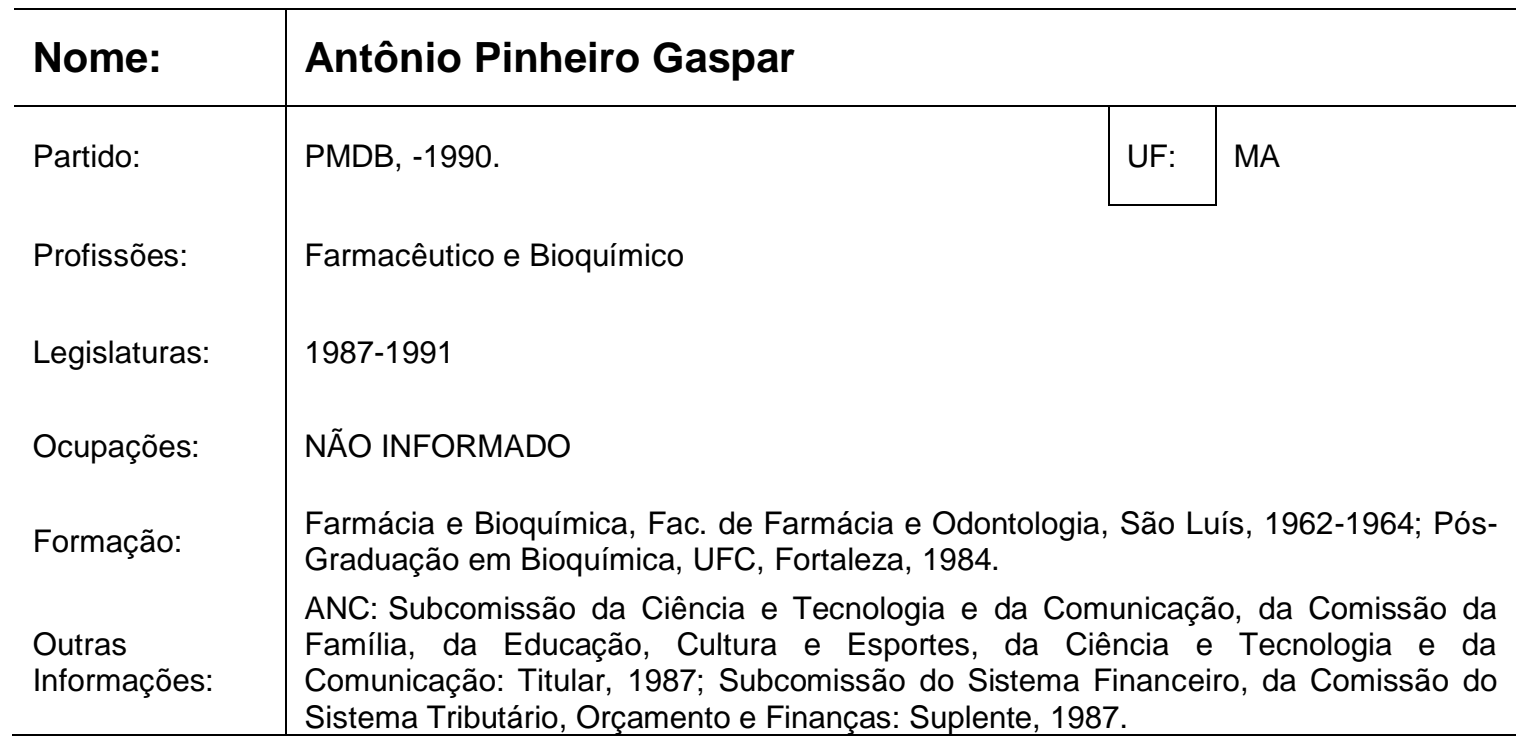

007

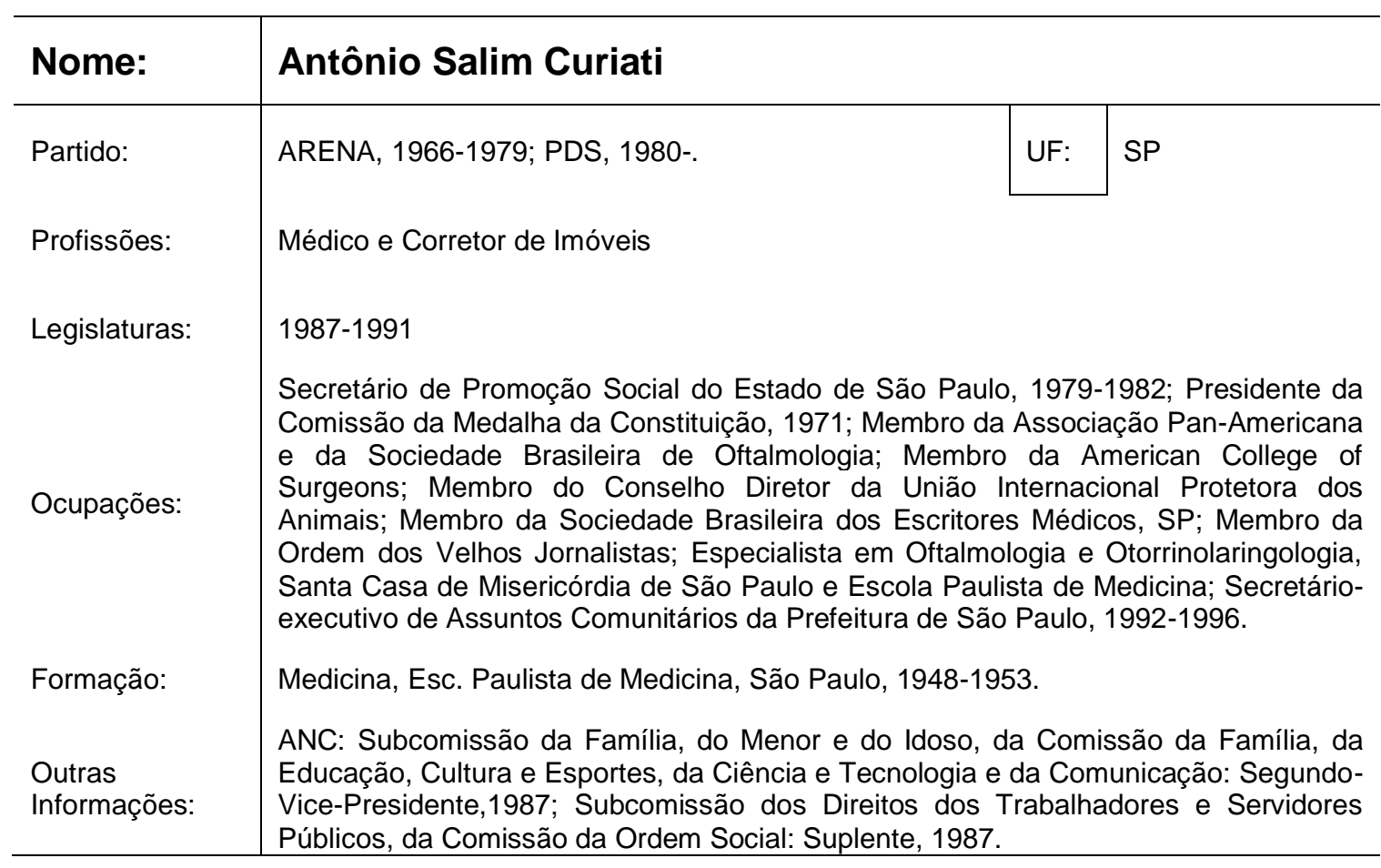


008

\begin{tabular}{l|l|l|l}
\hline Nome: & \multicolumn{2}{|l}{ Benedita Souza da Silva Sampaio } \\
\hline Partido: & PT, 1980-. & UF: & RJ \\
Profissões: & Servidora Pública, Professora, Auxiliar de Enfermagem e Assistente Social \\
Legislaturas: & $\begin{array}{l}\text { 1987-1991, 1991-1995, 2011-2015 e 2015-2019. } \\
\text { Professora, Escolinha Comunitária da Favela Chapéu Mangueira; Ministra, Ministério } \\
\text { de Desenvolvimento Social, Brasília, DF, 2003-2004; Secretária, Secretaria de } \\
\text { Estado de Assistencia Social e Direitos Humanos, Rio de Janeiro, RJ, 2007-2010; } \\
\text { Vendedora Ambulante; Empregada Doméstica. }\end{array}$ \\
Ocupações: & $\begin{array}{l}\text { Serviço Social, Faculdade de Serviço Social, Rio de Janeiro, RJ, 1980-1984. } \\
\text { Formação: }\end{array}$ & $\begin{array}{l}\text { ANC: Comissão da Soberania e dos Direitos e Garantias Homem e Mulher: Suplente, } \\
\text { 1987; Subcomissão dos Negros, População Indígena, Deficientes e Minorias: Titular; } \\
\text { Comissão da Ordem Social: Titular; Mesa da Assembleia Constituinte: Suplente. }\end{array}$ \\
\hline $\begin{array}{l}\text { Outras } \\
\text { Informações: }\end{array}$
\end{tabular}

009

\begin{tabular}{|c|c|c|c|}
\hline \multirow{2}{*}{$\begin{array}{l}\text { Nome: } \\
\text { Partido: }\end{array}$} & \multicolumn{3}{|l|}{ Luiz Carlos Borges da Silveira } \\
\hline & ARENA, 1971-1979; PP, 1980-1981; PMDB, 1981-. & UF: & PR \\
\hline Profissões: & \multicolumn{3}{|l|}{ Agropecuarista e Médico } \\
\hline Legislaturas: & \multicolumn{3}{|l|}{$1979-1983,1983-1987$ e $1987-1991$} \\
\hline Ocupações: & \multicolumn{3}{|c|}{$\begin{array}{l}\text { Coordenador Regional do Funrural, PR, 1977-1978; Ministro da Saúde, 1987-1988; } \\
\text { Chefe de Gabinete do Departamento de Assistência Técnica aos Municípios, Paraná, } \\
\text { 1961-1964; Médico-chefe do VII Distrito Sanitário da Secretaria de Saúde Pública do } \\
\text { Estado do Paraná, 1965-1970 }\end{array}$} \\
\hline Formação: & \multicolumn{3}{|c|}{$\begin{array}{l}\text { Medicina, UFPR, Curitiba, 1959-1964; Pós-Graduação em organização e } \\
\text { Administração sanitária, UFPR, Curitiba, } 1964 \text {. }\end{array}$} \\
\hline $\begin{array}{l}\text { Outras } \\
\text { Informações: }\end{array}$ & \multicolumn{3}{|c|}{$\begin{array}{l}\text { ANC: Subcomissão de Saúde, Seguridade e do Meio Ambiente, da Comissão da } \\
\text { Ordem Social: Titular, 1987; Subcomissão da Nacionalidade, da Soberania e das } \\
\text { Relações Internacionais, da Comissão da Soberania e dos Direitos e Garantias do } \\
\text { Homem e da Mulher: Suplente, } 1987 \text {. }\end{array}$} \\
\hline
\end{tabular}

010

\begin{tabular}{l|l|l|l}
\hline Nome: & João Bosco França Cruz & \multicolumn{2}{|l}{} \\
\hline Partido: & PMDB, 1985-1994; PMN, 1994-1998. & UF: & SE \\
\cline { 2 - 4 } & &
\end{tabular}




\begin{tabular}{|c|c|}
\hline Profissões: & Médico e Empresário \\
\hline Legislaturas: & $1987-1991$ e $1995-1999$. \\
\hline Ocupações: & NÃO INFORMADO \\
\hline Formação: & Medicina, UFS, Aracaju, SE, 1972-1978. \\
\hline $\begin{array}{l}\text { Outras } \\
\text { Informações: }\end{array}$ & $\begin{array}{l}\text { ANC: Subcomissão de Princípios Gerais, Intervenção do Estado, Regime da } \\
\text { Propriedade do Subsolo e da Atividade Econômica, da Comissão da Ordem } \\
\text { Econômica: Suplente, 1987; Subcomissão dos Negros, Populações Indígenas, } \\
\text { Pessoas Deficientes e Minorias, da Comissão da Ordem Social: Vice-Presidente, } \\
\text { 1987. }\end{array}$ \\
\hline
\end{tabular}

\section{1}

\begin{tabular}{|c|c|c|}
\hline Nome: & \multicolumn{2}{|l|}{ Carlos Cardinal Oliveira } \\
\hline Partido: & MDB, 1978-; PDT, 1980-. & RS \\
\hline Profissões: & \multicolumn{2}{|l|}{ Médico Veterinário } \\
\hline Legislaturas: & \multicolumn{2}{|l|}{ 1987-1991, 1991-1995 e 1995-1999. } \\
\hline Ocupações: & \multicolumn{2}{|c|}{$\begin{array}{l}\text { Secretário Municipal de Agricultura, São Luiz Gonzaga, RS, 1979; Secretário de } \\
\text { Agricultura e Abastecimento do Estado do Rio Grande do Sul, 1992-1993. }\end{array}$} \\
\hline $\begin{array}{l}\text { Outras } \\
\text { Informações: }\end{array}$ & \multicolumn{2}{|c|}{$\begin{array}{l}\text { Curso Ginasial, Colégio Miguel Fernandes, Bossoroca, RS; Secundário, Instituto } \\
\text { Porto Alegre, IPA, Porto Alegre, RS, 1968; Medicina Veterinária, UFSM, Santa Maria, } \\
\text { RS, 1969-1973. } \\
\text { ANC: Comissão de Sistematização: Titular, 1987-1988; Subcomissão da Política } \\
\text { Agrícola e Fundiária e da Reforma Agrária, da Comissão da Ordem Econômica: } \\
\text { Suplente, 1987; Subcomissão dos Estados, da Comissão da Organização do Estado: } \\
\text { Titular, 1987. }\end{array}$} \\
\hline
\end{tabular}

012

\begin{tabular}{l|l|l|l}
\hline Nome: & \multicolumn{2}{l}{ Carlos Alberto Cotta } \\
\hline Partido: & $\begin{array}{l}\text { PP; MDB, 1966-1979; PMDB, 1980-1989; PSDB, 1988- UF: } \\
\text { Profissões: }\end{array}$ & Médico & MG \\
Legislaturas: & $\begin{array}{l}\text { 1971-1975, 1975-1979, 1979-1983, 1983-1987 e 1987-1991. } \\
\text { Secretário do Governo e da Coordenação Política do Estado de Minas Gerais, 1983- } \\
1986 ; \text { Secretário da Fazenda; Secretário de Planejamento e Coordenação Geral; } \\
\text { Secretário de Trabalho e Ação Social; Secretário de Cultura; Presidente da } \\
\text { Companhia Mineradora de Minas Gerais (Comig), 1991. } \\
\text { 2o grau, Colégio São José, Juiz de Fora, MG; Medicina, Univ. do Brasil, Rio de } \\
\text { Janeiro, 1963. }\end{array}$ \\
\cline { 2 - 2 } &
\end{tabular}


Outras

Informações:

ANC: Subcomissão dos Direitos dos Trabalhadores e Servidores Públicos, da Comissão da Ordem Social: Titular, 1987; Subcomissão da Família, do Menor e do Idoso, da Comissão da Família, da Educação, Cultura e Esportes, da Ciência e Tecnologia e da Comunicação: Suplente, 1987.

013

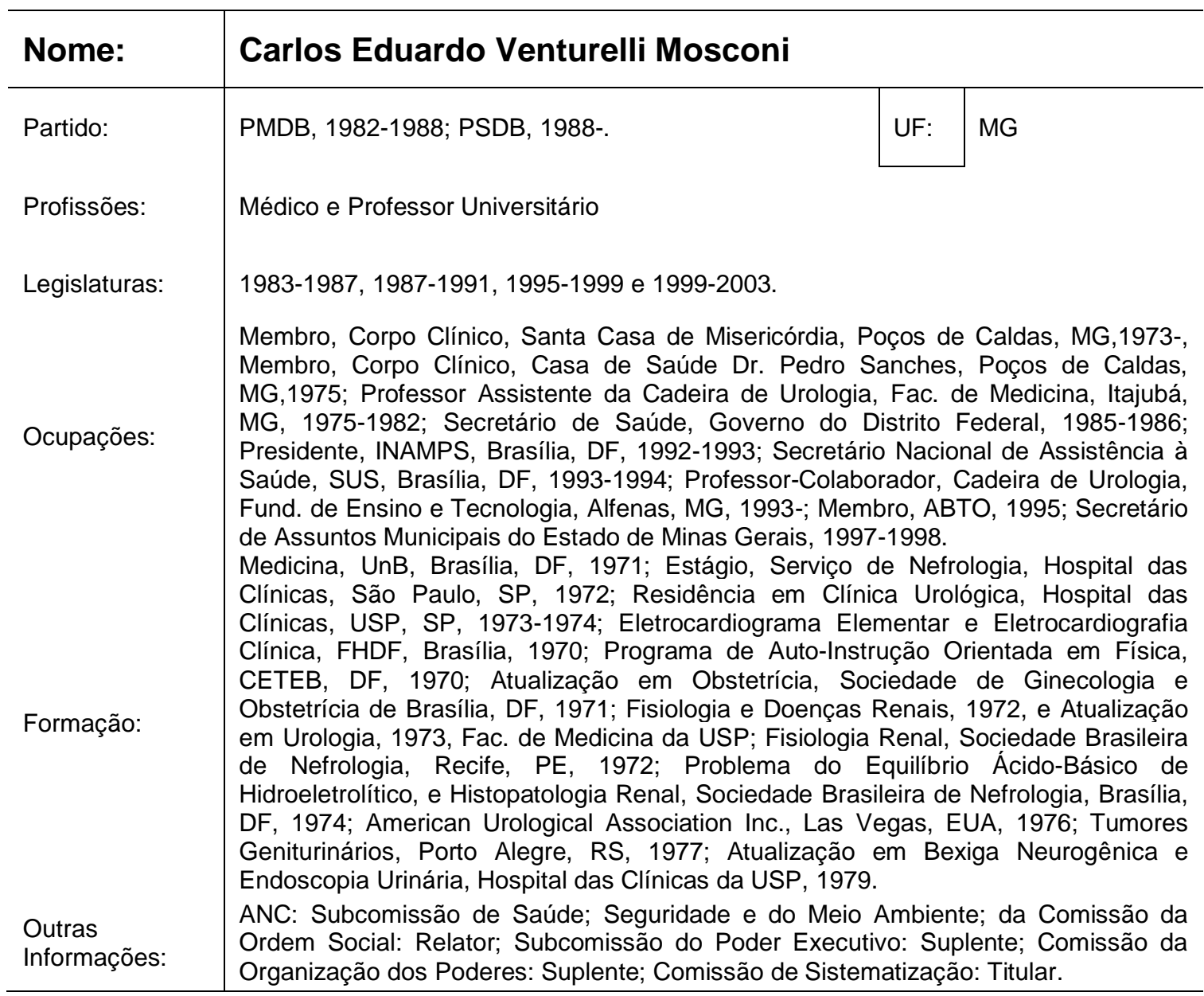

\section{4}

\begin{tabular}{l|l|l|l}
\hline Nome: & \multicolumn{2}{|l}{ Carlos Corrêa de Menezes Sant'Anna } \\
\hline Partido: & $\begin{array}{l}\text { ARENA, 1975-1980; PP, 1980-1981; PMDB, 1980-1981; } \\
\text { PP, 1994-. }\end{array}$ & UF: & BA \\
Profissões: & Médico e Professor \\
Legislaturas: & $\begin{array}{l}\text { 1979-1983, 1983-1987, 1987-1991 e 1991-1995. } \\
\text { Conselheiro efetivo da Fundação Hospitalar do Estado da Bahia e de diretor-geral do } \\
\text { Departamento de Assistência da Secretaria da Saúde Pública, 1971; Coordenador do } \\
\text { programa materno-infantil da Fundação Secretaria de Saúde do Estado da Bahia } \\
\text { (Fusep), 1973; Professor Adjunto, Fac. de Medicina, UFBA; Secretário de Educação }\end{array}$ \\
\end{tabular}


e Cultura do Estado da Bahia, 1975-1978; Ministro de Estado da Saúde, 1985-1986; Ministro de Estado da Educação, 1989-1990; Secretário de Governo do Distrito Federal, 1991-1992; Secretário de Saúde do Distrito Federal, 1992-1993;

Medicina, UFBA, Salvador, 1950-1955; Pediatria social, Centro Internacional da

Formação: $\quad$ Criança, Paris, França, 1971; Curso superior de guerra, Escola Superior de Guerra (ESG), 1973;

Outras $\quad$ ANC: Subcomissão de Saúde, Seguridade e do Meio Ambiente, da Comissão da Informações: Ordem Social: Suplente, 1987; Comissão de Sistematização: Titular, 1987-1988.

\section{5}

\begin{tabular}{|c|c|c|}
\hline Nome: & \multicolumn{2}{|l|}{ Célio de Castro } \\
\hline Partido: & PMDB; PSDB, 1988-1990; PSB, 1990-. & MG \\
\hline Profissões: & \multicolumn{2}{|l|}{ Médico e Professor } \\
\hline Legislaturas: & \multicolumn{2}{|l|}{$1987-1991$ e $1991-1995$} \\
\hline Ocupações: & \multicolumn{2}{|c|}{ Funcionário do Departamento de Estradas de Rodagem, DER, 1958-1970. } \\
\hline Formação: & \multirow{2}{*}{\multicolumn{2}{|c|}{$\begin{array}{l}\text { Medicina, UFMG, Belo Horizonte, 1952-1958. } \\
\text { ANC: Subcomissão dos Direitos dos Trabalhadores e Servidores Públicos, da } \\
\text { Comissão da Ordem Social: Titular, 1987; Subcomissão da Família, do Menor e do } \\
\text { ldoso, da Comissão da Família, da Educação, Cultura e Esportes, da Ciência e } \\
\text { Tecnologia e da Comunicação: Suplente, } 1987 \text {. }\end{array}$}} \\
\hline $\begin{array}{l}\text { Outras } \\
\text { Informações: }\end{array}$ & & \\
\hline
\end{tabular}

016

\begin{tabular}{|c|c|c|c|}
\hline \multirow{2}{*}{$\begin{array}{l}\text { Nome: } \\
\text { Partido: }\end{array}$} & \multicolumn{3}{|c|}{ Francisco Humberto de Freitas Azevedo } \\
\hline & PDT, -1990; PST, 1990-. & UF: & $M G$ \\
\hline Profissões: & \multicolumn{3}{|l|}{ Médico e Produtor Rural } \\
\hline Legislaturas: & \multicolumn{3}{|l|}{$1987-1991$} \\
\hline Ocupações: & \multicolumn{3}{|c|}{ Um dos Fundadores do PDT no Triângulo Mineiro. } \\
\hline Formação: & \multicolumn{3}{|c|}{ Medicina, Univ. Federal de Uberlândia, Uberlândia, 1967-1973. } \\
\hline $\begin{array}{l}\text { Outras } \\
\text { Informações: }\end{array}$ & \multicolumn{3}{|c|}{$\begin{array}{l}\text { Diretor da Uesu - União dos Estudantes Secundáristas de Uberlândia, } 1963- \\
1964 \text {. Membro Fundador e Primeiro-Vice-Presidente do Dadu - Diretório } \\
\text { Acadêmico Domingos Pimentel de Uchoa, da Faculdade de Medicina } \\
\text { Universidade Federal de Uberlândia, 1968-1969. Um dos Fundadores do } \\
\text { PDT no Triângulo Mineiro. }\end{array}$} \\
\hline
\end{tabular}


017

\begin{tabular}{l|l|l}
\hline Nome: & \multicolumn{2}{|l}{ Dalton Moreira Canabrava } \\
\hline Partido: & UDN, 1959-1964; MDB, 1966-1979; PMDB, 1980-. $\quad$ UF: & MG \\
Profissões: & Médico e Empresário Rural \\
Legislaturas: & $1987-1991$ \\
Ocupações: & Médico do Inamps do Hospital Santo Antônio, Curvelo. \\
Formação: & $\begin{array}{l}\text { Medicina, UFMG, Belo Horizonte. } \\
\text { ANC: Subcomissão do Poder Executivo, da Comissão da Organização dos } \\
\text { Poderes e Sistema de Governo: Titular, 1987; Subcomissão da Questão } \\
\text { Urbana e Transporte, da Comissão da Ordem Econômica: Suplente, } \\
\text { 1988. Membro da Associação Médica de Minas Gerais. Médico do Inamps } \\
\text { do Hospital Santo Antônio, Curvelo; Seu tio-avô, José Cupertino Siqueira, foi } \\
\text { deputado federal de 1894 a 1899. }\end{array}$ \\
\hline
\end{tabular}

018

\begin{tabular}{|c|c|c|c|}
\hline \multirow{2}{*}{$\begin{array}{l}\text { Nome: } \\
\text { Partido: }\end{array}$} & \multicolumn{3}{|l|}{ Daso de Oliveira Coimbra } \\
\hline & PTB; PSD; ARENA; PRN; PDS; PP; PMDB; PP & UF: & RJ \\
\hline Profissões: & \multicolumn{3}{|l|}{ Médico, Jornalista e Professor } \\
\hline Legislaturas: & \multicolumn{3}{|c|}{$\begin{array}{l}\text { 1963-1967, } 1967-1971,1971-1975,1975-1979,1979-1983,1983-1987 \text { e } \\
1987-1991\end{array}$} \\
\hline Ocupações: & \multirow{3}{*}{\multicolumn{3}{|c|}{$\begin{array}{l}\text { Diretor do Colégio Estadual de Niterói, RJ, 1954; Fundador, } 1965 \text { do Grupo } \\
\text { Parlamentar Cristão e Seu Presidente nos Anos 1970, 1974, 1978, } 1982- \\
1983 \text { e 1986-1988. Vice-Presidente, 1969-1970 e Presidente, 1971-1972 do } \\
\text { Diretório Estadual da Arena, Rio de Janeiro. } \\
\text { Geografia Superior da América Latina, Instituto Rio Branco (MRE), Rio de } \\
\text { Janeiro, 1945; História e Geografia, URJ, RJ, 1946; Medicina, Fac. } \\
\text { Fluminense de Medicina, Niterói, 1953. } \\
\text { ANC: Subcomissão de Defesa do Estado, da Sociedade e de sua } \\
\text { Segurança: Segundo-Vice-Presidente, 1987; Comissão da Organização } \\
\text { Eleitoral, Partidária e Garantia das Instituições: Segundo-Vice-Presidente, } \\
\text { 1987; Comissão de Sistematização: Suplente, 1987-1988. }\end{array}$}} \\
\hline Formação: & & & \\
\hline $\begin{array}{l}\text { Outras } \\
\text { Informações: }\end{array}$ & & & \\
\hline
\end{tabular}

019

\begin{tabular}{l|l|l|l}
\hline Nome: & \multicolumn{3}{|l}{ Dirce Maria do Valle Quadros } \\
\hline Partido: & $\begin{array}{l}\text { PSC; PFL, 1985-1986; PTB, 1987-1988; PSDB, } \\
\text { 1988-1990; PMDB, 1990-. }\end{array}$ & UF: & SP \\
\cline { 2 - 4 } & &
\end{tabular}




\begin{tabular}{l|l}
\cline { 2 - 2 } Profissões: & Pesquisadora da Nasa. \\
Legislaturas: & $1987-1991$ \\
Ocupações: & NÃO INFORMADO \\
Formação: & $\begin{array}{l}\text { Ciências, Univ. do Texas, EUA, 1968-1972; Phd em Citologia, Univ. do } \\
\text { Texas, EUA, 1968-1972. }\end{array}$ \\
Outras & $\begin{array}{l}\text { ANC: Subcomissão dos Direitos e Garantias Individuais: Titular, 1987; } \\
\text { Comissão da Soberania e dos Direitos e Garantias do Homem e da Mulher: } \\
\text { Informações: }\end{array}$ \\
\hline
\end{tabular}

020

\begin{tabular}{l|l|l|l}
\hline Nome: & \multicolumn{3}{|l}{ Djenal Gonçalves Soares } \\
\hline Partido: & $\begin{array}{l}\text { ARENA, 1979-; PDS, 1980-1993; PPR, 1993- } \\
\text { 1994; PSDB, 1994-. } \\
\text { Profissões: }\end{array}$ & Médico e Professor & SE \\
Legislaturas: & $\begin{array}{l}\text { 1987-1991 e 1991-1995. } \\
\text { Ossistente Médico, FUNRURAL, 1970-1972; Chefe, Departamento de } \\
\text { Cirurgia da UFS, 1978-1981; Professor, Fac. de Medicina da UFS, 1978; } \\
\text { Médico, INAMPS, Aracaju, 1978; Vice-Reitor, UFS, Aracaju, SE, 1981-1982 }\end{array}$ \\
Formação: & $\begin{array}{l}\text { Medicina, Ufs, Aracaju, 1972-1977. } \\
\text { ANC: Subcomissão dos Direitos e Garantias Individuais; Comissão da } \\
\text { Soberania e dos Direitos e Garantias do Homem e da Mulher: Titular, 1987; } \\
\text { Subcomissão do Poder Judiciário e do Ministério Público: Suplente, 1987; } \\
\text { Comissão da Organização dos Poderes e Sistema de Governo: Suplente, } \\
1987 .\end{array}$ \\
\hline
\end{tabular}

021

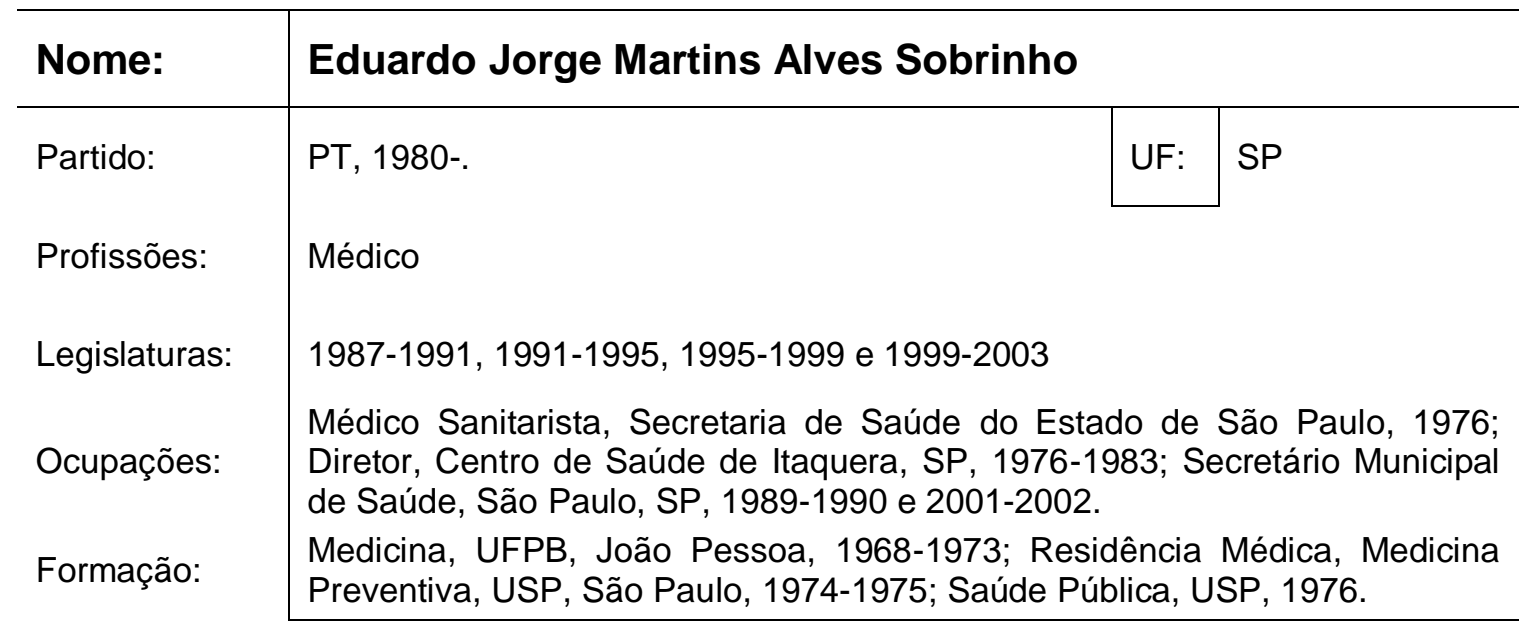


Outras

ANC: Subcomissão de Princípios Gerais, Intervenção do Estado, Regime da

Informações: $\quad$ Econômica: Suplente; Subcomissão de Saúde, Seguridade e do Meio Ambiente, da Comissão da Ordem Social: Titular.

022

\begin{tabular}{|c|c|c|}
\hline Nome: & Eduardo Pinho Moreira & \\
\hline Partido: & PMDB & SC \\
\hline Profissões: & \multicolumn{2}{|l|}{ Médico } \\
\hline Legislaturas: & \multicolumn{2}{|l|}{$1987-1991$ e $1991-1995}$. \\
\hline Ocupações: & \multicolumn{2}{|l|}{ Médico, INAMPS, Criciúma, SC, 1975.} \\
\hline Formação: & \multicolumn{2}{|l|}{ Medicina, UFJF, Juiz de Fora, MG, 1968-1972. } \\
\hline $\begin{array}{l}\text { Outras } \\
\text { Informações: }\end{array}$ & \multicolumn{2}{|c|}{$\begin{array}{l}\text { ANC: Subcomissão de Saúde, Seguridade e do Meio Ambiente, da } \\
\text { Comissão da Ordem Social: Titular, 1987; Subcomissão da Educação, } \\
\text { Cultura e Esportes, da Comissão da Família, da Educação, Cultura e } \\
\text { Esportes, da Ciência e Tecnologia e da Comunicação: Suplente, } 1987 .\end{array}$} \\
\hline
\end{tabular}

023

\begin{tabular}{|c|c|c|}
\hline Nome: & \multicolumn{2}{|l|}{ José Elias Murad } \\
\hline Partido: & PTB, 1987-1989; PSDB, 1989-. & $M G$ \\
\hline Profissões: & \multirow{2}{*}{\multicolumn{2}{|c|}{$\begin{array}{l}\text { Médico } \\
\text { 1987-1991, 1991-1995, 1995-1999 e 1999-2003 }\end{array}$}} \\
\hline Legislaturas: & & \\
\hline Ocupações: & $\begin{array}{l}\text { Professor, UFMG, 1949-1983; Livre-Docente de } \\
\text { Farmacognosia, UFMG; Professor Titular de Farmacod } \\
\text { Farmácia, UFMG, 1955-1983; Professor Catedrático, } \\
\text { Reitor, 1970-1973, e Reitor, 1973-1975, Col. Estadual } \\
\text { Diretor, Fac. de Farmácia de Minas Gerais, 1973-1979; Ti } \\
\text { Catedrático) de Farmacologia e Diretor eleito por } 4 \text { mand } \\
\text { 1973-1987, Fac. de Ciências Médicas de Minas Gera } \\
\text { Pesquisa da UFMG, 1979; Professor Emérito, Fac. de } \\
\text { 1984- } \\
\text { Farmácia, UFMG, Belo Horizonte, 1946-1948; Química, } \\
\text { Belo Horizonte, 1950-1951; Medicina, UFMG, Belo Hori } \\
\text { Especialização em Psicofarmacologia, Univ. de Paris, F } \\
\text { Especialização em Bioquímica Cerebral, Univ. do Texas, } \\
\text { 1965; Especialização em Planejamento Familiar, Univ. d } \\
\text { 1978; Bolsista, American College of Phisicians, EUA, 1983 }\end{array}$ & $\begin{array}{l}\text { Fitoquímica e } \\
\text { inâmica, Fac. de } \\
\text { 1965-1970, Vice- } \\
\text { de Minas Gerais; } \\
\text { tular (ex-Professor } \\
\text { atos consecutivos, } \\
\text { is; Pró-Reitor de } \\
\text { Farmácia, UFMG, } \\
\text { Esc. de Filosofia, } \\
\text { zonte, 1950-1955. } \\
\text { ança, 1959-1960; } \\
\text { allas, EUA, 1964- } \\
\text { o Colorado, EUA, }\end{array}$ \\
\hline
\end{tabular}


Outras

ANC: Subcomissão da Família, do Menor e do Idoso, da Comissão da

Informações:

Família, da Educação, Cultura e Esportes, da Ciência e Tecnologia e da

Comunicação: Suplente; Subcomissão de Saúde, Seguridade e do Meio

Ambiente, da Comissão da Ordem Social: Presidente.

024

\begin{tabular}{l|l|l}
\hline Nome: & \multicolumn{2}{|l}{ Euclides Girolamo Scalco } \\
\hline Partido: & $\begin{array}{l}\text { PTB, 1960-1966; MDB, 1966-1979; PMDB, 1980- } \\
\text { 1988; PSDB, 1988-. }\end{array}$ & UF: PR \\
Profissões: & Farmacêutico Químico \\
Legislaturas: & $\begin{array}{l}\text { 1979-1983, 1983-1987 e 1987-1991 } \\
\text { Proprietário de Farmácias em Mussum, RS e Bento Gonçalves, RS; Chefe } \\
\text { da Casa Civil, PR, 1983-1985; Diretor-presidente. Empresa Habitação } \\
\text { Construções e Empreendimentos Ltda, em Curitiba, PR, 1992-1995; } \\
\text { Coordenador, Instituto Ciência e Fé, 1995-1998, em Curitiba, PR. }\end{array}$ \\
Forupações: & $\begin{array}{l}|c| \\
\text { Formação: }\end{array}$ & $\begin{array}{l}\text { ANC: Comissão da Organização Eleitoral: Titular, 1987; Comissão de } \\
\text { Sistematização: Suplente, 1987/1988; Subcomissão de Garantia da } \\
\text { Constituição: Titular, 1987; Partidária e Garantia das Instituições: Titular, } \\
\text { 1987; Reforma e Emendas: Titular, 1987 }\end{array}$ \\
$\begin{array}{l}\text { Outras } \\
\text { Informações: }\end{array}$ \\
\hline
\end{tabular}

025

\begin{tabular}{|c|c|c|}
\hline \multirow{2}{*}{$\begin{array}{l}\text { Nome: } \\
\text { Partido: }\end{array}$} & \multicolumn{2}{|l|}{ Fadah Scaff Gattass } \\
\hline & PMDB; PSD, 1948-1964. & MS \\
\hline Profissões: & \multicolumn{2}{|l|}{ Médico e Pecuarista } \\
\hline Legislaturas: & \multicolumn{2}{|l|}{$1987-1991$} \\
\hline Ocupações: & \multicolumn{2}{|c|}{$\begin{array}{l}\text { Médico Sanitarista, lotado no Serviço de Saúde dos Portos e Aeroportos de } \\
\text { Fronteira, 1951-1981; prestou serviços como Médico à comunidade } \\
\text { corumbaense e ladarense no IAPETEC, posteriormente transformado em } \\
\text { INPS; Presidente da Liga Árabe de Corumbá. }\end{array}$} \\
\hline Formação: & \multicolumn{2}{|c|}{$\begin{array}{l}\text { Medicina, Univ. do Brasil, Rio de Janeiro, 1945; concluiu Cursos Técnicos e } \\
\text { de Especialização. }\end{array}$} \\
\hline $\begin{array}{l}\text { Outras } \\
\text { Informações: }\end{array}$ & \multicolumn{2}{|c|}{ ANC: COMISSÕES: de Relações Exteriores: Titular; do Interior: Suplente. } \\
\hline
\end{tabular}


026

\begin{tabular}{|c|c|c|c|}
\hline Nome: & \multicolumn{3}{|l|}{ Genésio Bernardino de Souza } \\
\hline Partido: & $\begin{array}{l}\text { PSD, 1966; MDB, 1966-1979; PP, 1980-1981; } \\
\text { PMDB, 1982-. }\end{array}$ & UF: & MG \\
\hline Profissões: & \\
\hline Legislaturas: & \\
\hline Ocupações: & \multicolumn{3}{|c|}{$\begin{array}{l}\text { Chefe da Unidade Sanitária, 1951-1960, e Médico do Departamento de } \\
\text { Medicina Social, 1962-1965, Secretaria de Saúde e Assistência do Estado } \\
\text { de Minas Gerais, Manhumirim; Chefe da Clínica Oftalmológica, 1952-1960, e } \\
\text { Chefe da Clínica Otorrinolaringológica, 1957-1960, Hospital São Vicente de } \\
\text { Paula, Manhumirim, MG; Médico Especialista, Clínic Sta. Inês, Belo } \\
\text { Horizonte, MG; Médico Especialista, Hospital do Câncer, Secretaria de } \\
\text { Saúde e Assistência Social, MG, 1964; Representante do Ministério da } \\
\text { Saúde e Executor do Convênio da Saúde Pública com a Companhia Vale do } \\
\text { Rio Doce, 1965-1966; Chefe do Serviço Médico-Sanitário, Prefeitura de Belo } \\
\text { Horizonte, MG, 1967-1968; Membro, designado pelo Presidente da } \\
\text { República, Junta Federal de Saúde do Estado de Minas Gerais, 1968; } \\
\text { Membro, Comissão de Credenciamento para Exames Médicos Psicotécnicos } \\
\text { da Secretaria de Segurança Pública do Estado de Minas Gerais; Diretor, } \\
\text { Serviço Médico do DETRAN, Belo Horizonte, MG, 1967-1970; Médico } \\
\text { Sanitarista, Prefeitura Municipal, Belo Horizonte, MG, 1969-1970; Chefe do } \\
\text { Serviço Médico, Departamento de Trânsito da Secretaria de Segurança } \\
\text { Pública, Estado de Minas Gerais; Diretor, Departamento de Medicina } \\
\text { Preventiva, 1969-1970, e Departamento de Profilaxia, 1969, Prefeitura de } \\
\text { Belo Horizonte, MG; Oficial de Gabinete do Primeiro-Ministro Tancredo } \\
\text { Neves, 1987; Secretário de Governo e Coordenação Política do Estado de } \\
\text { Minas Gerais, 1987; Diretor-Geral, DNER, 1999-2000. } \\
\text { Medicina, UFMG, Belo Horizonte, 1945-1950; Residência-Médica, Hospital } \\
\text { Neuropsiquiátrico Infantil do Estado de Minas Gerais, 1949-1950; Cirurgia } \\
\text { Médica, Belo Horizonte, MG; Curso de Sanitarista, Esc. da Saúde Pública do } \\
\text { Estado de Minas Gerais, Belo Horizonte, 1950; Curso Intensivo sobre } \\
\text { Doença de Chagas, Fac. de Segurança Pública, MG. }\end{array}$} \\
\hline $\begin{array}{l}\text { Outras } \\
\text { Informações: }\end{array}$ & & & \\
\hline
\end{tabular}

027

\begin{tabular}{|c|c|c|c|}
\hline \multirow{2}{*}{$\begin{array}{l}\text { Nome: } \\
\text { Partido: }\end{array}$} & \multicolumn{3}{|l|}{ Geraldo José Rodrigues Alckmin Filho } \\
\hline & $\begin{array}{l}\text { MDB, 1972-1979; PMDB, 1980-1988; PSDB, } \\
\text { 1988-. }\end{array}$ & UF: & SP \\
\hline Profissões: & \multicolumn{3}{|l|}{ Médico } \\
\hline Legislaturas: & \multicolumn{3}{|l|}{$1987-1991$ e $1991-1995}$. \\
\hline Ocupações: & \multicolumn{3}{|c|}{$\begin{array}{l}\text { Chefe, Departamento de Anestesiologia da Santa Casa de Misericórdia, } \\
\text { Pindamonhangaba, SP; Professor de Fisiologia, como auxiliar de ensino, }\end{array}$} \\
\hline
\end{tabular}




\begin{tabular}{l|l}
\cline { 2 - 2 } & $\begin{array}{l}\text { Fundação Salesiana de Filosofia, Ciências e Letras, Lorena, SP, 1974-1976; } \\
\text { Professor de Enfermagem Neuropsiquiátrica, Curso Técnico de } \\
\text { Enfermagem, Instituto Santa Tereza, Lorena, SP, 1975. }\end{array}$ \\
Formação: & $\begin{array}{l}\text { Medicina, Fac. de Medicina, Taubaté, SP, 1971-1977; Pós-Graduação em } \\
\text { Anestesiologia, Hospital Servidor Público, SP, 1978-1979. }\end{array}$ \\
ANC: Subcomissão de Saúde, Seguridade e do Meio Ambiente, da \\
Informações: & $\begin{array}{l}\text { Comissão da Ordem Social: Titular, 1987; Subcomissão do Sistema Eleitoral } \\
\text { e Partidos Políticos, da Comissão da Organização Eleitoral, Partidária e } \\
\text { Garantia das Instituições: Suplente, 1987. }\end{array}$ \\
\hline
\end{tabular}

028

\begin{tabular}{l|l|l}
\hline Nome: & \multicolumn{2}{|l}{ Geraldo Reis Fleming } \\
\hline Partido: & PTB, 1961-1966; MDB, 1966-1979; PMDB, 1980-. UF: & AC \\
Profissões: & Militar e Médico Veterinário \\
Legislaturas: & $\begin{array}{l}\text { 1979-1983, 1983-1987 e 1987-1991 } \\
\text { Ocupações: }\end{array} \quad \begin{array}{l}\text { Secretário de Agricultura, Indústria e Comércio, AC; Secretário de } \\
\text { Segurança, Interior e Justiça, AC } \\
\text { Medicina Veterinária, Esc. Fluminense de Medicina Veterinária, Rio de } \\
\text { Janeiro; Estágio de aperfeiçoamento e pós-graduação na Argentina e no }\end{array}$ \\
Formação: & $\begin{array}{l}\text { Uruguai. } \\
\text { ANC: Subcomissão de Tributos, Participação e Distribuição das Receitas: } \\
\text { Titular, 1987; Comissão do Sistema Tributário Orçamento e Finanças: : }\end{array}$ \\
Outras \\
Informações: & $\begin{array}{l}\text { Titular, 1987; Suplente, Subcomissão de Defesa do Estado, da Sociedade e } \\
\text { de sua Segurança: Suplente, 1987; Comissão da Organização Eleitoral, } \\
\text { Partidária e Garantia das Instituições: Suplente, 1987. }\end{array}$ \\
\hline
\end{tabular}

029

\begin{tabular}{l|l|l|l}
\hline Nome: & \multicolumn{3}{|l}{ Inocêncio Gomes de Oliveira } \\
\hline Partido: & $\begin{array}{l}\text { ARENA, 1975-1979; PDS, 1980-1985; PFL, 1985- } \\
\text { 2005; PMDB, 2005; PL, 2005-2007; PR, 2007-. }\end{array}$ & PF: \\
Profissões: & Médico & \\
Legislaturas: & $\begin{array}{l}1975-1979,1979-1983,1983-1987,1987-1991,1991-1995,1995-1999, \\
1999-2003,2003-2007,2007-2011 \text { e 2011-2015. }\end{array}$ \\
& $\begin{array}{l}\text { Diretor-Presidente, Casa de Saúde e Maternidade São Vicente, 1974; } \\
\text { Cirurgião-Chefe, Hospital Agamenon Magalhães, 1974; Coordenador de }\end{array}$ \\
Acidentes do Trabalho, INPS, Serra Talhada, PE, 1974; Presidente da \\
Ocupações: & $\begin{array}{l}\text { República, como substituto constitucional, 17/2/1993; Presidente da } \\
\text { República, como substituto constitucional, 24/5/1993-29/5/1993; Presidente } \\
\text { da República, como substituto constitucional, 10/7/1993; Presidente da } \\
\text { República, como substituto constitucional, 14/10/1993-17/10/1993; } \\
\text { Presidente da República, como substituto constitucional, 15/1/1194- } \\
18 / 1 / 1994 ; \text { Presidente da República, como substituto constitucional, }\end{array}$ \\
\cline { 2 - 2 }
\end{tabular}


22/1/1994; Presidente da República, como substituto constitucional, 3/3/1994-5/3/1994; Presidente da República, como substituto constitucional, 10/3/1994-13/3/1994; Presidente da República, como substituto constitucional, 9/12/1994-14/12/1994.

Formação: $\quad$ Medicina, UFPE, Recife, 1963.

ANC: Comissão de Redação: Titular; Comissão de Sistematização: Titular;

Outras

Informações: Subcomissão dos Municípios e Regiões, da Comissão da Organização do Estado: Suplente. Presidente, Sociedade de Medicina de Pernambuco, Seccional de Serra Talhada, 1975.

\section{0}

\begin{tabular}{l|l|l}
\hline Nome: & Jairo Azi \\
\hline Partido: & $\begin{array}{l}\text { PR; ARENA; PDS, 1980-1985; PFL, 1986-1988; } \\
\text { PDC, 1988-1993; PPR, 1993; PSD, 1993-1994; UF: }\end{array}$ & BA \\
PFL, 1994-2000; PPR, 1994-. & Mefissões: & Médico \\
Legislaturas: & $\begin{array}{l}\text { 1983-1987, 1987-1991, 1991-1995, 1995-1999 e 1999-2003. } \\
\text { Ocupações: }\end{array}$ & $\begin{array}{l}\text { Médico, INAMPS e Secretaria de Saúde da Bahia; Secretário Municipal de } \\
\text { Saúde, Alagoinhas, BA; Diretor da LBA, BA. }\end{array}$ \\
Formação: & $\begin{array}{l}\text { Medicina, Esc. de Medicina e Saúde Pública. } \\
\text { ANC: Subcomissão do Poder Executivo, da Comissão da Organização dos }\end{array}$ \\
Outras & $\begin{array}{l}\text { Poderes e Sistema de Governo: Suplente; Subcomissão dos Direitos e } \\
\text { Informações: } \\
\text { do Homem e da Mulher: Titular. }\end{array}$ \\
\hline
\end{tabular}

031

\begin{tabular}{|c|c|c|c|}
\hline \multirow{2}{*}{$\begin{array}{l}\text { Nome: } \\
\text { Partido: }\end{array}$} & \multicolumn{3}{|l|}{ Joaquim Sucena Rasga } \\
\hline & PP, 1980-1982; PMDB, 1982-1986; PTB, 1988-. & UF: & MT \\
\hline Profissões: & \multicolumn{3}{|l|}{ Médico } \\
\hline Legislaturas: & \multicolumn{3}{|l|}{$1987-1991$ e $1991-1995$} \\
\hline Ocupações: & \multicolumn{3}{|c|}{$\begin{array}{l}\text { Secretário Municipal de Saúde, Cuiabá, MT, 1974-1978; Secretário Chefe da } \\
\text { Casa Civil do Governo, Cuiabá, MT,1991; Chefe da Assessoria Parlamentar, } \\
\text { Ministério da Saúde, Brasília, DF, 1991; Secretário da Saúde do Estado de } \\
\text { Mato Grosso, 1993-1994. }\end{array}$} \\
\hline Formação: & \multicolumn{3}{|l|}{ Medicina, UFRJ, Rio de Janeiro, 1965-1969. } \\
\hline $\begin{array}{l}\text { Outras } \\
\text { Informações: }\end{array}$ & \multicolumn{3}{|c|}{$\begin{array}{l}\text { ANC: Subcomissão de Saúde, Seguridade e do Meio Ambiente: Titular: } \\
\text { 1987; Comissão da Ordem Social: Titular, 1987; Subcomissão de Tributos, } \\
\text { Participação e Distribuição das Receitas: Suplente, 1987; Comissão do }\end{array}$} \\
\hline
\end{tabular}


Sistema Tributário, Orçamento e Finanças: Suplente, 1987.

032

\begin{tabular}{l|l|l}
\hline Nome: & Jofran Frejat \\
\hline Partido: & $\begin{array}{l}\text { PFL, 1986-1994; PP, 1994-1995; PPB, 1995-2003; UF: } \\
\text { PTB, 2005-2007; PR, 2007-. }\end{array}$ \\
Profissões: & Médico \\
Legislaturas: & $\begin{array}{l}\text { 1987-1991, 1991-1995, 1995-1999, 1999-2003 e 2007-2011 } \\
\text { Diretor, IML, Brasília, DF, 1973-1979; Secretário de Saúde do Distrito }\end{array}$ \\
Ocupações: & $\begin{array}{l}\text { Federal, 1979-1983, 1991-1992, 1994 e 1999-2002; Secretário-Geral do } \\
\text { MPAS, Brasília, DF, 1983-1985; Ministro de Estado, Interino, da Previdência } \\
\text { e Assistência Social, 1984; Chefe do Serviço de Cirurgia-Geral, HRAS, } \\
\text { Brasília, DF. }\end{array}$ \\
Formação: & $\begin{array}{l}\text { Medicina, FNMRJ, Rio de Janeiro, 1957-1962; Pós-Graduação em Medicina, } \\
\text { Univ. de Londres, Inglaterra, 1971-1972. } \\
\text { ANC: Comissão de Sistematização: Suplente; Subcomissão da União, } \\
\text { Distrito Federal e Territórios, da Comissão da Organização dos Estados: } \\
\text { Presidente; Subcomissão de Saúde, Seguridade e do Meio Ambiente, da } \\
\text { Comissão da Ordem Social: Suplente. }\end{array}$ \\
Outras &
\end{tabular}

033

\begin{tabular}{|c|c|c|c|}
\hline \multirow{2}{*}{$\begin{array}{l}\text { Nome: } \\
\text { Partido: }\end{array}$} & \multicolumn{3}{|l|}{ Jonas Pinheiro da Silva } \\
\hline & PDS, 1982-1985; PFL, 1985-. & UF: & MT \\
\hline Profissões: & \multicolumn{3}{|c|}{ Extensionista Rural e Médico Veterinário } \\
\hline Legislaturas: & \multicolumn{3}{|c|}{ 1983-1987, $1987-1991$ e $1991-1995}$. \\
\hline Ocupações: & \multicolumn{3}{|c|}{$\begin{array}{l}\text { Técnico Agrícola no Serviço Social Rural, SUPRA/INDA, 1962-1965; Agente } \\
\text { de Extensão Rural, Associação de Crédito e Assistência Rural, Jaciara, MT, } \\
\text { 1965-1970; Extensionista Rural, Jaciara e Juscimeira, 1965-1970; Professor } \\
\text { de Agricultura e Língua Portuguesa, Corpo da Paz, Colorado, EUA, 1970; } \\
\text { Médico Veterinário, 1975-1979, e Coordenador, 1976-1978, POLOCENTRO; } \\
\text { Presidente, EMATER, MT, 1979-1982; Secretário de Assuntos para o Interior } \\
\text { do Estado do Mato Grosso, 1985. }\end{array}$} \\
\hline Formação: & \multicolumn{3}{|c|}{ Medicina Veterinária, UFMT, Cuiabá, 1974.} \\
\hline $\begin{array}{l}\text { Outras } \\
\text { Informações: }\end{array}$ & \multicolumn{3}{|c|}{$\begin{array}{l}\text { ANC: Subcomissão da Política Agrícola e Fundiária e da Reforma Agrária: } \\
\text { Titular, 1987; Comissão da Ordem Econômica: Titular, 1987; Comissão de } \\
\text { Sistematização: Suplente, 1987-1988. }\end{array}$} \\
\hline
\end{tabular}


034

\begin{tabular}{|c|c|c|c|}
\hline \multirow{2}{*}{$\begin{array}{l}\text { Nome: } \\
\text { Partido: }\end{array}$} & \multicolumn{3}{|l|}{ Jorge Vianna Dias da Silva } \\
\hline & MDB, 1965-1979; PTB, 1980-1981; PMDB, 1982-. & UF: & BA \\
\hline Profissões: & \multicolumn{3}{|l|}{ Agricultor e Médico } \\
\hline Legislaturas: & \multicolumn{3}{|l|}{ 1979-1983, 1983-1987 e 1987-1991. } \\
\hline Ocupações: & \multicolumn{3}{|c|}{$\begin{array}{l}\text { Médico Legista, BA; Médico do Serviço Nacional da Lepra, 1965-1966; } \\
\text { Médico do Inamps, BA; Diretor do Serviço Médico da Associação dos } \\
\text { Funcionários Públicos do Estado da Bahia, 1977-1979. }\end{array}$} \\
\hline Formação: & \multirow{2}{*}{\multicolumn{3}{|c|}{$\begin{array}{l}\text { Medicina, Fac. de Medicina da Bahia, Salvador, 1956-1962. } \\
\text { ANC: Subcomissão da Política Agrícola e Fundiária e da Reforma Agrária, } \\
\text { da Comissão da Ordem Econômica: Titular, 1987; Subcomissão de Defesa } \\
\text { do Estado, da Sociedade e de sua Segurança, da Comissão da Organização } \\
\text { Eleitoral, Partidária e Garantia das Instituições: Suplente, } 1987 .\end{array}$}} \\
\hline $\begin{array}{l}\text { Outras } \\
\text { Informações: }\end{array}$ & & & \\
\hline
\end{tabular}

035

\begin{tabular}{l|l|l|l}
\hline Nome: & \multicolumn{3}{|l}{ José Tinoco Machado de Albuquerque } \\
Profido: & PFL; ARENA, 1972-1979; PDS, 1980-1985. & UF: & PE \\
\hline Legislaturas: & Médico e Professor & $\begin{array}{l}\text { 1987-1991 } \\
\text { Médico-cirurgião do INAMPS, Garanhus, PE, 1965-1978; Médico-cirurgião } \\
\text { da Secretaria de Saúde do Estado de Pernambuco, 1965-1986; Chefe da }\end{array}$ \\
Clínica do Hospital Regional Dom Moura, Garanhus, PE, 1966-1974; Chefe \\
do Setor de Acidente de Trabalho do INAMPS, Garanhus, PE, 1967-1974;
\end{tabular}




\begin{tabular}{l|l|l}
\hline Nome: & \multicolumn{2}{l}{ Lúcio Gonçalo de Alcântara } \\
\hline Partido: & $\begin{array}{l}\text { PDT; ARENA, 1978-1979; PDS, 1980-1985; PFL, UF: } \\
\text { 1986- }\end{array}$ & CE \\
Profissões: & Médico \\
Legislaturas: & $\begin{array}{l}\text { 1983-1987 e 1987-1991 } \\
\text { Orofessor Adjunto do Departamento de Saúde Comunitária, Centro de } \\
\text { Ciências de Saúde, UFC; Médico do Inamps; Secretário de Saúde, CE, } \\
1971-1973 ; \text { Secretário de Saúde, CE, 1975-1978; Secretário para Assuntos } \\
\text { Municipais, CE, 1978-1979. }\end{array}$ \\
Formação: & $\begin{array}{l}\text { Medicina, Universidade de Fortaleza, Fortaleza, 1961-1966. } \\
\text { ANC: Subcomissão do Poder Legislativo: Titular, 1987; da Comissão da } \\
\text { Organização dos Poderes e Sistema de Governo: Titular, 1987; } \\
\text { Subcomissão de Saúde, Seguridade e do Meio Ambiente: Suplente, 1987; } \\
\text { da Comissão da Ordem Social: Suplente, 1987. }\end{array}$ \\
Outras \\
Informações:
\end{tabular}

037

\begin{tabular}{|c|c|c|c|}
\hline Nome: & \multicolumn{3}{|l|}{ Jorge Maluly Netto } \\
\hline tido: & . $106-1979$, rLS, $1980-1984$, TrL, $1980-$. & UF: & SP \\
\hline fissões: & \multicolumn{3}{|c|}{$\begin{array}{l}\text { PSD, 1963-1965; MDB, 1966-1967; ARENA, 1967-1979; PDS, 1980-1984; } \\
\text { PFL, 1985-. }\end{array}$} \\
\hline & \multirow{2}{*}{\multicolumn{3}{|c|}{$\begin{array}{l}\text { 1979-1983, 1983-1987, 1987-1991, 1991-1995, 1995-1999 e 1999-2003. } \\
\text { Médico, Hospital das Clínicas de Mirandópolis, SP; Médico, Secretaria de } \\
\text { Saúde, Mirandópolis, SP, 1957-1978; Secretário Extraordinário, 1975, e } \\
\text { Secretário de Relações do Trabalho do Estado de São Paulo, 1975-1978; } \\
\text { Agente de Serviço Civil, Secretaria de Trabalho do Estado de São Paulo, } \\
\text { 1978. } \\
\text { Medicina, Univ. Brasil, Rio de Janeiro, RJ, 1951-1956; Direito, Fac. de Direito } \\
\text { Brás Cubas, Mogi das Cruzes, SP, 1968-1972. Especialização na área de } \\
\text { Medicina, Fac. Nacional de Medicina, Rio de Janeiro, RJ, 1950-1956; } \\
\text { Especialização na área de Direito, Fac. de Direito Brás Cubas, Mogi das } \\
\text { Cruzes, SP, 1968-1972; Especialização em Medicina do Trabalho, ADESG- } \\
\text { FUNDACENTRO, São Paulo, SP, 1976. } \\
\text { ANC: Subcomissão da Política Agrícola e Fundiária e da Reforma Agrária, } \\
\text { da Comissão da Ordem Econômica: Titular; Subcomissão dos Direitos e } \\
\text { Garantias Individuais, da Comissão da Soberania e dos Direitos e Garantias } \\
\text { do Homem e da Mulher: Titular. Membro, Congregação da Escola Paulista } \\
\text { de Medicina, 1989-1991. }\end{array}$}} \\
\hline S: & & & \\
\hline
\end{tabular}

038

Nome: $\quad$ Manuel Francisco Viana Neto 


\begin{tabular}{l|l|l|l}
\hline Partido: & MDB, 1974-; PMDB, 1980-. & UF: & CE \\
Profissões: & Médico \\
Legislaturas: & $\begin{array}{l}\text { 1983-1987, 1987-1991 e 1991-1995 } \\
\text { Chefe, Setor de Negrologia, S.A. Socorros Médicos (SOS) e Instituto José }\end{array}$ \\
Ocupações: & $\begin{array}{l}\text { Frota, Fortaleza, CE; Diretor-Presidente, Ana Nery Hospitalar Ltda.; Diretor- } \\
\text { Clínico, Clínica Miguel Couto; Médico, INAMPS; Médico, Prefeitura Municipal } \\
\text { de Fortaleza, CE. }\end{array}$ \\
Formação: & $\begin{array}{l}\text { Medicina, UFC, Fortaleza, CE, 1975 (conclusão). } \\
\text { ANC: Subcomissão da Nacionalidade, da Soberania e das Relações } \\
\text { Internacionais, da Comissão da Soberania e dos Direitos e Garantias do } \\
\text { Outras } \\
\text { Informações: } \\
\text { 1987-1988. }\end{array}$ \\
\hline
\end{tabular}

039

\begin{tabular}{l|l|l}
\hline Nome: & \multicolumn{2}{|l|}{ Maria de Lourdes Abadia } \\
\hline Partido: & PFL, 1985-1988; PSDB, 1988-. & UF: \\
Profissões: & Professora, Assistente Social e Consultora \\
Legislaturas: & $\begin{array}{l}\text { 1987-1991 e 1999-2003. } \\
\text { Professora, FEDF, Brasília, 1970-1972; Coordenadora de Serviço Social, } \\
\text { Ocupações: }\end{array} \quad \begin{array}{l}\text { Secretaria do Serviço Social do Distrito Federal, 1972-1975; Administradora } \\
\text { da Ceilândia, Secretaria de Governo do Distrito Federal, 1975-1985; } \\
\text { Diretora-Executiva, FSS, Brasília, DF, 1985-1986; Secretária de Turismo do } \\
\text { Distrito Federal, 1995; Secretária de Estado de Coordenação das } \\
\text { Administrações Reginais do Governo do Distrito Federal, 2001-2002. } \\
\text { Assumiu em 31 de dezembro de 2002, na legislatura 1999-2003, o mandato } \\
\text { de Vice-Governadora do Distrito Federal. } \\
\text { Serviço Social, UnB, Brasília, DF, 1969-1972; Administração Pública, Meio } \\
\text { Ambiente e Urbanismo Comunitário, Fund. Alemã para o Desenvolvimento } \\
\text { Internacional, Berlim, 1978; Desenvolvimento Internacional, Fund. Kellog's, } \\
\text { Minnesota, EUA, 1984-1986. } \\
\text { ANC: Subcomissão de Saúde, Seguridade e Meio Ambiente, da Comissão } \\
\text { da Ordem Social: Segunda Vice-Presidente; Subcomissão dos Direitos } \\
\text { Políticos, Direitos Coletivos e Garantias da Comissão da Soberania e dos } \\
\text { Direitos e Garantias do Homem e da Mulher: Suplente. }\end{array}$ \\
Formação:
\end{tabular}

040

\begin{tabular}{l|l|l|l}
\hline Nome: & \multicolumn{3}{l}{$\mid$} \\
\hline Partido: & MDB, 1974-1979; PMDB, 1980-; PRN, 1990-. & UF: & PR \\
\cline { 2 - 4 }
\end{tabular}




\begin{tabular}{l|l}
\cline { 2 - 2 } $\begin{array}{l}\text { Profissões: } \\
\text { Legislaturas: }\end{array}$ & $\begin{array}{l}\text { Agropecuarista, Médico e Empresário } \\
1983-1987 \text { e 1987-1991 } \\
\text { Ocupações: }\end{array}$ \\
Formação: & $\begin{array}{l}\text { Medicina, UFPR, Curitiba, 1969. } \\
\text { ANC: Subcomissão dos Negros, Populações Indígenas, Pessoas Deficientes }\end{array}$ \\
$\begin{array}{l}\text { Outras } \\
\text { Informações: }\end{array}$ & $\begin{array}{l}\text { e Minorias: Titular, 1987; Comissão da Ordem Social: Titular, 1987; } \\
\text { Subcomissão de Saúde, Seguridade e do Meio Ambiente: Suplente, 1987; } \\
\text { Comissão da Ordem Social: Suplente, 1987. }\end{array}$ \\
\hline
\end{tabular}

\section{1}

\begin{tabular}{|c|c|c|c|}
\hline \multirow{2}{*}{$\begin{array}{l}\text { Nome: } \\
\text { Partido: }\end{array}$} & \multicolumn{3}{|l|}{ José Mauro Castelo Branco Sampaio } \\
\hline & $\begin{array}{l}\text { ARENA, 1967-1979; PDS, 1980-1985; PMDB, } \\
\text { 1986-1990; PSDB, 1990-1994; PMDB, 1994-. }\end{array}$ & UF: & CE \\
\hline Profissões: & \multicolumn{3}{|l|}{ Médico } \\
\hline Legislaturas: & \multicolumn{3}{|c|}{ 1975-1979, 1979-1983, 1983-1987, 1987-1991 e 1991-1995. } \\
\hline Ocupações: & \multicolumn{3}{|c|}{$\begin{array}{l}\text { Secretário do Planejamento e Coordenação do Estado do Ceará, 1970; } \\
\text { Secretário da Fazenda, do estado do Ceará, } 1970 .\end{array}$} \\
\hline Formação: & \multicolumn{3}{|c|}{$\begin{array}{l}\text { Medicina, Faculdade de Ciências Médicas da Univ. do Rio de Janeiro, DF, } \\
1952 \text { (conclusão). }\end{array}$} \\
\hline $\begin{array}{l}\text { Outras } \\
\text { Informações: }\end{array}$ & \multicolumn{3}{|l|}{-} \\
\hline
\end{tabular}

042

\begin{tabular}{l|l|l|l}
\hline Nome: & \multicolumn{2}{|l}{ João Miraldo Dos Santos Gomes } \\
\hline Partido: & PMDB, 1986-1988; PDC, 1988-. & UF: & BA \\
Profissões: & Médico e Empresário & \\
Legislaturas: & $1987-1991$ \\
Ocupações: & NÃO INFORMADO \\
Formação: & $\begin{array}{l}\text { Medicina, UFBA, Salvador, 1965-1970; Pós-Graduação em Medicina, Univ. } \\
\text { do Chile Santiago, 1975. } \\
\text { Criou, em 1979, na Cidade de Feira de Santana, BA, a Maternidade Estela } \\
\text { Gomes, tendo permanecido como seu Diretor até as eleições de novembro } \\
\text { de 1986. Membro efetivo da Academia Feirense de Letras. Secretário de }\end{array}$ \\
$\begin{array}{l}\text { Outras } \\
\text { Informações: }\end{array}$ & \multicolumn{2}{l}{}
\end{tabular}


Saúde, Feira de Santana, BA, 1997.

043

\begin{tabular}{l|l|l}
\hline Nome: & \multicolumn{2}{|l}{ Francisco Mozarildo de Melo Cavalcanti } \\
\hline Partido: & $\begin{array}{l}\text { PFL, -1990; ARENA, 1970-1979; PDS, 1980-1984; UF: } \\
\text { PL, 1990-. }\end{array}$ & RR \\
Profissões: & Médico e Professor \\
Legislaturas: & $\begin{array}{l}\text { 1983-1987 e 1987-1991 } \\
\text { Diretor, Hospital Nossa Senhora de Fátima; Diretor, Hospital Coronel Mota; } \\
\text { Diretor, Maternidade de Boa Vista, RR; Secretário de Saúde, RR; Assessor } \\
\text { Especial do Governador do Estado de Roraima; Professor da Universidade }\end{array}$ \\
Ocupações: & $\begin{array}{l}\text { Federal de Roraima; Doutor Honoris causa. } \\
\text { Fedicina, UFPA, Belém, PA, 1964-1969. }\end{array}$ \\
Formação: & $\begin{array}{l}\text { MNC: Subcomissão da União, Distrito Federal e Territórios, da Comissão da } \\
\text { Outras } \\
\text { Informações: }\end{array}$ & \begin{tabular}{l} 
Suplente, 1987-1988. \\
\hline
\end{tabular}
\end{tabular}

044

\begin{tabular}{l|l|l}
\hline Nome: & Nelson de Carvalho Seixas \\
\hline Partido: & $\begin{array}{l}\text { ARENA, 1971-1979; PDS, 1980-1982; PMDB, UF: } \\
1983-1985 ; \text { PDT, 1986-1990; PSDB, 1990- }\end{array}$ \\
Profissões: & Médico \\
Legislaturas: & $\begin{array}{l}1987-1991 \text { e 1991-1995. } \\
\text { Chefe de clínica, Santa Casa de São José do Rio Preto, SP, 1955-1967; } \\
\text { Médico, INAMPS, São José do Rio Preto, SP, 1958-; Presidente, Banco do } \\
\text { Desenvolvimento de São Paulo, 1979-1980; Secretário Municipal de Saúde, } \\
\text { São José do Rio Preto, SP, 1983-1985 }\end{array}$ \\
Formação: & $\begin{array}{l}\text { Medicina, USP, São Paulo, 1947-1952. } \\
\text { ANC: Subcomissão dos Negros, Populações Indígenas, Pessoas Deficientes } \\
\text { e Minorias, da Comissão da Ordem Social: Titular, 1987; Subcomissão de } \\
\text { Saúde, Seguridade e do Meio Ambiente, da Comissão da Ordem Social: } \\
\text { Suplente, 1987. }\end{array}$ \\
\hline
\end{tabular}




\begin{tabular}{l|l|l}
\hline Nome: & Ottomar de Sousa Pinto \\
\hline Partido: & $\begin{array}{l}\text { PDS, 1980-1984; PMDB, 1987-1990; PTB, 1988-; UF: RR } \\
\text { PDC, 1990; PTB, 1990-. }\end{array}$ \\
Legislaturas: & $\begin{array}{l}\text { Industrial, Engenheiro Civil, Médico e Engenheiro Militar } \\
\text { Ocupações: }\end{array}$ & $\begin{array}{l}\text { Chefe da Comissão de Aeroportos da Amazônia - Comara, Belém, Pa, 1972- } \\
\text { 1979; Brigadeiro (engenheiro), Ministério da Aeronáutica, 1979. }\end{array}$ \\
Formação: & $\begin{array}{l}\text { Formação de Oficiais Esc. de Aeronáutica Campo dos Afonsos, 1948-1952; } \\
\text { Engenharia Civil, Esc. Nacional de Engenharia, Rio de Janeiro, 1951-1955; } \\
\text { Medicina, FNM, Rio de Janeiro, 1962-1967; Engenharia Elétrica, UFRJ, Rio } \\
\text { de Janeiro, 1965-1967; Aperfeiçoamento de Oficiais, EAOAC, Cumbica, } \\
\text { 1968; Mestrado em Pavimentação, Texas A \& M University, Texas, 1970; } \\
\text { Mestrado em Transportes, Berkeley Univ., Califórnia, 1971; Estado-Maior, } \\
\text { ECEMAR, Rio de Janeiro, 1972-1973; Direito, UFPA, Belém, 1974-1977; } \\
\text { Economia, FICOM, Belém, 1984. } \\
\text { ANC: Subcomissão de Defesa do Estado, da Sociedade e de sua } \\
\text { Segurança, da Comissão da Organização Eleitoral, Partidária e Garantia das } \\
\text { Instituições: Titular, 1987; Comissão de Sistematização: Suplente, 1987- } \\
\text { 1988. }\end{array}$ \\
\hline $\begin{array}{l}\text { Outras } \\
\text { Informações: }\end{array}$ \\
\hline
\end{tabular}

046

\begin{tabular}{|c|c|c|c|}
\hline Nome: & \multicolumn{3}{|l|}{ Pedro Chaves Canedo } \\
\hline Partido: & $\begin{array}{l}\text { PDS, 1981-1985; PFL, 1985-1990; PRN, 1990- } \\
\text { 1994; PP, 1994-1995; PL, 1995-1999; PSDB, } \\
\text { 1999-2005; PP, 2005-. }\end{array}$ & UF: & GO \\
\hline es: & \multicolumn{3}{|l|}{ Médico } \\
\hline s: & \multicolumn{3}{|l|}{ 1987-1991, 1995-1999, 1999-2003 e 2003-2007 } \\
\hline Ocup & \multicolumn{3}{|c|}{$\begin{array}{l}\text { Radialista Sonoplasta, Rádio Imprensa, Anápolis, GO, 1963; Médico-Chefe, } \\
\text { Clínica Oftalmológica da Policlínica Militar, Rio de Janeiro, RJ, 1974-1975; } \\
\text { Diretor-Presidente, Clínica de Olhos Santa Luzia, Anápolis, GO, 1976-; } \\
\text { Primeiro-Diretor, Departamento de Oftalmologia, Anápolis, GO, 1982; } \\
\text { Assessor Parlamentar do Ministério da Saúde, 1991-1992; Diretor- } \\
\text { Presidente, Clínica Personna Stauffer, Goiânia, GO, 1993-. }\end{array}$} \\
\hline Formação: & \multicolumn{3}{|c|}{$\begin{array}{l}\text { Medicina, UFRJ, Rio de Janeiro, 1968-1973; Residência Médica, Santa Casa } \\
\text { de Misericórdia, Rio de Janeiro, RJ, 1974-1975. }\end{array}$} \\
\hline $\begin{array}{l}\text { Outras } \\
\text { Informa }\end{array}$ & \multicolumn{3}{|c|}{$\begin{array}{l}\text { ANC: Subcomissão de Educação, Cultura e Esportes, da Comissão da } \\
\text { Família, da Educação, Cultura e Esportes, da Ciência e Tecnologia e da } \\
\text { Comunicação: Segundo Vice-Presidente; Subcomissão de Saúde, } \\
\text { Seguridade e do Meio Ambiente, da Comissão da Ordem Social: Suplente. }\end{array}$} \\
\hline
\end{tabular}




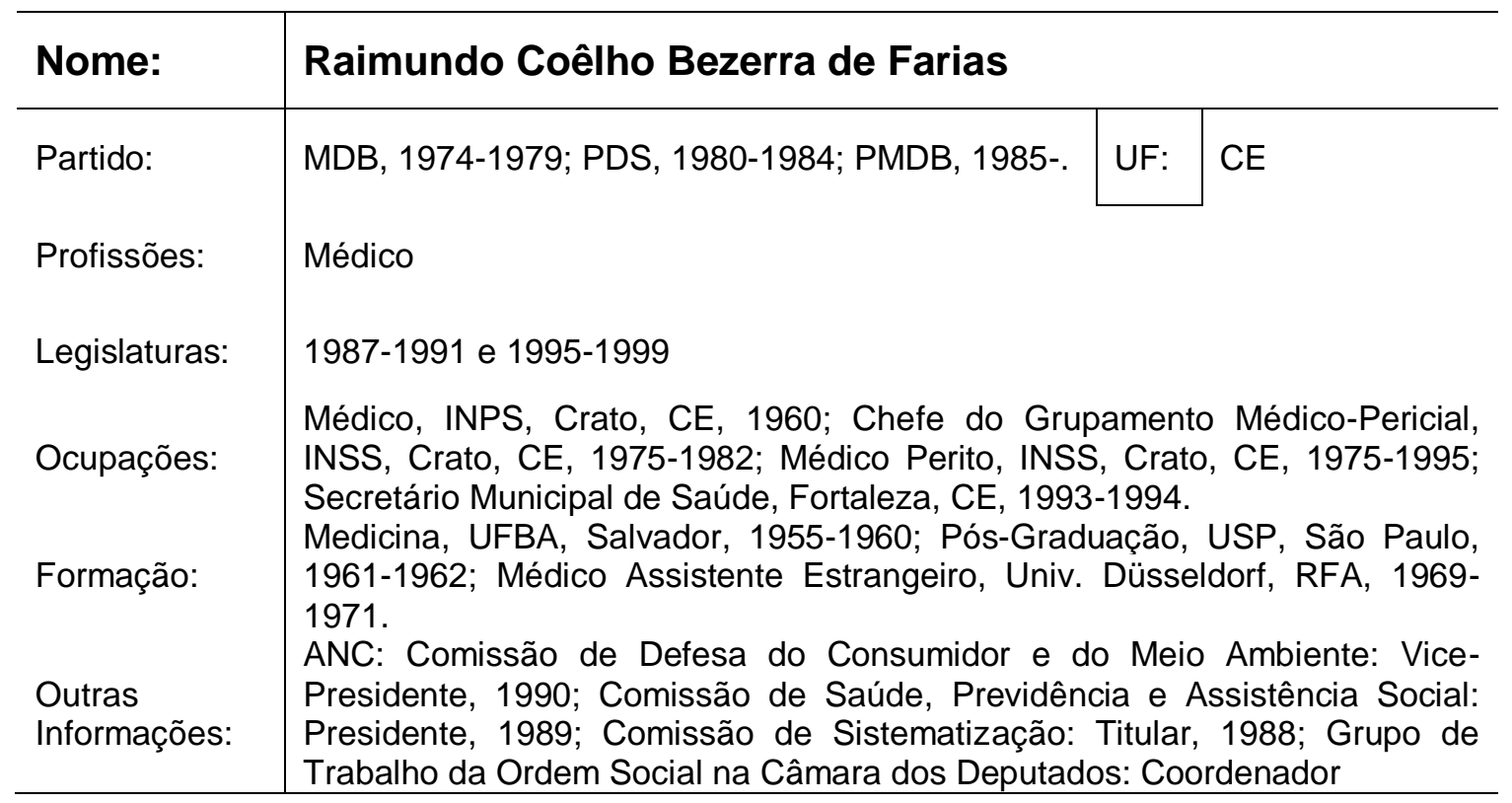

048

\begin{tabular}{|c|c|c|c|}
\hline \multirow{2}{*}{$\begin{array}{l}\text { Nome: } \\
\text { Partido: }\end{array}$} & \multicolumn{3}{|l|}{ Raimundo Monteiro de Rezende } \\
\hline & PTB, 1963-1966; MDB, 1966-1979; PMDB, 1980-. & UF: & MG \\
\hline Profissões: & \multicolumn{3}{|l|}{ Médico } \\
\hline Legislaturas: & \multicolumn{3}{|l|}{$1987-1991$} \\
\hline Ocupações: & \multicolumn{3}{|l|}{ Médico do Inps; Secretário de Saúde, MG, 1985-1986. } \\
\hline Formação: & \multicolumn{3}{|l|}{ Medicina, Univ. do Brasil, Rio de Janeiro, 1942-1947. } \\
\hline $\begin{array}{l}\text { Outras } \\
\text { Informações: }\end{array}$ & \multicolumn{3}{|c|}{$\begin{array}{l}\text { ANC: Subcomissão de Saúde, Seguridade e do Meio Ambiente, da } \\
\text { Comissão da Ordem Social: Titular, 1987; Subcomissão dos Municípios e } \\
\text { Regiões, da Comissão da Organização do Estado: Suplente, } 1987 \text {. }\end{array}$} \\
\hline
\end{tabular}

049

\begin{tabular}{l|l|l|l}
\hline Nome: & \multicolumn{2}{l}{ Raquel Cândido e Silva } \\
\hline Partido: & $\begin{array}{l}\text { PMDB, 1981-1986; PFL, 1986-1988; PDT, 1988- } \\
\text { 1994. }\end{array}$ & UF: & RO \\
Profissões: & Técnica em Saúde & & \\
Legislaturas: & $1987-1991$ e 1991-1995. & \\
\cline { 2 - 3 }
\end{tabular}




\begin{tabular}{|c|c|}
\hline Ocupações: & $\begin{array}{l}\text { Motorista de Táxi; Funcionária, ELETRONORTE; Funcionária, Governo do } \\
\text { Território de Rondônia; Comerciária. }\end{array}$ \\
\hline Formação: & Filosofia, (incomp.), PUC, São Paulo, SP. \\
\hline $\begin{array}{l}\text { Outras } \\
\text { Informações: }\end{array}$ & $\begin{array}{l}\text { ANC: Subcomissão de Princípios Gerais, Intervenção do Estado, Regime da } \\
\text { Propriedade do Subsolo e da Atividade Econômica, da Comissão da Ordem } \\
\text { Econômica: Titular, 1987; Subcomissão de Saúde, Seguridade e do Meio } \\
\text { Ambiente, da Comissão da Ordem Social: Suplente, 1987; }\end{array}$ \\
\hline
\end{tabular}

050

\begin{tabular}{|c|c|c|c|}
\hline \multirow{2}{*}{$\begin{array}{l}\text { Nome: } \\
\text { Partido: }\end{array}$} & \multicolumn{3}{|l|}{ Roberto Vital Ferreira } \\
\hline & PP; MDB; PMDB; PRN, 1989-. & UF: & MG \\
\hline Profissões: & \multicolumn{3}{|l|}{ Médico } \\
\hline Legislaturas: & \multicolumn{3}{|l|}{$1987-1991$} \\
\hline Ocupações: & \multicolumn{3}{|l|}{ NÃO INFORMADO } \\
\hline Formação: & \multicolumn{3}{|c|}{ Medicina, FCM, Belo Horizonte, 1971-1979. } \\
\hline $\begin{array}{l}\text { Outras } \\
\text { Informações: }\end{array}$ & \multicolumn{3}{|c|}{$\begin{array}{l}\text { ANC: Subcomissão da Ciência e Tecnologia e da Comunicação, da } \\
\text { Comissão da Família, da Educação, Cultura e Esportes, da Ciência e } \\
\text { Tecnologia e da Comunicação: Titular, 1987; Subcomissão de Saúde, } \\
\text { Seguridade e do Meio Ambiente, da Comissão da Ordem Social: Suplente, } \\
\text { 1987. }\end{array}$} \\
\hline
\end{tabular}

051

\begin{tabular}{|c|c|c|c|}
\hline \multirow{2}{*}{$\begin{array}{l}\text { Nome: } \\
\text { Partido: }\end{array}$} & \multicolumn{3}{|l|}{ Ruy Germano Nedel } \\
\hline & $\begin{array}{l}\text { MDB, 1974-1979; PMDB, 1980-1990; PSDB, } \\
\text { 1990-. }\end{array}$ & UF: & RS \\
\hline Profissões: & \multicolumn{3}{|l|}{ Médico } \\
\hline Legislaturas: & \multicolumn{3}{|l|}{$1987-1991$} \\
\hline Ocupações: & \multicolumn{3}{|c|}{$\begin{array}{l}\text { Servidor Público Estadual da Secretaria de Administração do Estado do Rio } \\
\text { Grande do Sul, 1960-1966; Serventuário da Justiça do Trabalho, TRT, Porto } \\
\text { Alegre, RS, 1967-1970; Superintendente do Inamps Porto Alegre, RS, 1985- } \\
\text { 1986. }\end{array}$} \\
\hline Formação: & \multirow{2}{*}{\multicolumn{3}{|c|}{$\begin{array}{l}\text { Medicina, Fac. Fed. de Ciências Médicas, Porto Alegre, 1961-1966. } \\
\text { ANC: Subcomissão dos Negros, Populações Indígenas, Pessoas Deficientes } \\
\text { e Minorias, da Comissão da Ordem Social: Titular, 1987; Subcomissão de } \\
\text { Garantia da Constituição, Reformas e Emendas, da Comissão da } \\
\text { Organização Eleitoral, Partidária e Garantia das Instituições: Suplente, } 1987 .\end{array}$}} \\
\hline $\begin{array}{l}\text { Outras } \\
\text { Informações: }\end{array}$ & & & \\
\hline
\end{tabular}


052

\begin{tabular}{l|l|l}
\hline Nome: & \multicolumn{2}{|l}{ Uldurico Alves Pinto } \\
\hline Partido: & $\begin{array}{l}\text { PMDB, 1987-1991; PSB, 1991-1995; PMN, 1995- } \\
\text { 2009; PHS, 2009-1991. } \\
\text { Profissões: }\end{array}$ & Médico e Cacauicultor \\
Legislaturas: & $\begin{array}{l}\text { 1987-1991, 1991-1995 e 2007-2011. } \\
\text { Chefe da Unidade Sanitária de Almas, GO, 1978-1979; Diretor Científico, }\end{array}$ \\
Ocupações: & $\begin{array}{l}\text { Fundação Cardiológica de Goiás, 1983; Médico, Prefeitura Municipal de } \\
\text { Almas, TO; Médico, Prefeitura Municipal de Natividade, TO; Secretário de } \\
\text { Saúde, Prefeitura Municipal de Porto Seguro, BA. }\end{array}$ \\
Formação: & $\begin{array}{l}\text { Medicina, UFMG, Belo Horizonte, 1972-1977. } \\
\text { ANC: Subcomissão dos Direitos Políticos, dos Direitos Coletivos e Garantias, } \\
\text { da Comissão da Soberania e dos Direitos e Garantias do Homem e da } \\
\text { Mulher: 2o Vice-Presidente, 1987; Comissão de Sistematização: Suplente, } \\
\text { 1987-1988. }\end{array}$ \\
Outras \\
Informações:
\end{tabular}

053

\begin{tabular}{l|l|l}
\hline Nome: & Victor Fontana \\
\hline Partido: & $\begin{array}{l}\text { PSD, 1950-1966; ARENA, 1966-1979; PDS, 1980- } \\
\text { 1985; PFL, 1986-. }\end{array}$ & SC \\
Profissões: & $\begin{array}{l}\text { Agricultor, Empresário, Balconista, Telegrafista, Estivador de Porto, Auxiliar } \\
\text { de laboratório, Químico Analista e Bacteriologista }\end{array}$ \\
Legislaturas: & $\begin{array}{l}\text { 1979-1983 e 1987-1991 } \\
\text { Diretor Industrial da Sadia, 1953-1964; Diretor, Moinho da Lapa, 1963-1964 } \\
\text { e 1969-1973; Diretor-exectivo, Frigobrás, 1969-1971; Assessor do Secretário } \\
\text { da Agricultura de São Paulo; Assessor do Prefeito Municipal de São Paulo; }\end{array}$ \\
Ocupações: & $\begin{array}{l}\text { Secretário de Agricultura e Abastecimento, Santa Catarina, 1975-1978; } \\
\text { Presidente, Celesc, Santa Catarina, 1994. }\end{array}$ \\
Formação: & $\begin{array}{l}\text { Engenharia Química, UFRS, Porto Alegre, 1944-1947. } \\
\text { ANC: Subcomissão da Política Agrícola e Fundiária e da Reforma Agrária, } \\
\text { da Comissão da Ordem Econômica: Titular, 1987; Subcomissão do Sistema }\end{array}$ \\
Outras & $\begin{array}{l}\text { Financeiro, da Comissão do Sistema Tributário, Orçamento e e } \\
\text { Finanças:Suplente, 1987. }\end{array}$ \\
\hline
\end{tabular}

054

Nome: Jerônimo Vingt Rosado Maia 


\begin{tabular}{l|l|l|l}
\hline Partido: & $\begin{array}{l}\text { PMDB; UDN, 1948-1953; PSD, 1953-1966; } \\
\text { ARENA, 1966-1979; PDS, 1980-1985. }\end{array}$ & RN \\
Profissões: & $\begin{array}{l}\text { Industrial, Pecuarista, Contador e Farmacêutico } \\
\text { Legislaturas: }\end{array}$ & $\begin{array}{l}\text { 1963-1967, 1967-1971, 1971-1975, 1975-1979, 1979-1983, 1983-1987 e } \\
1987-1991 .\end{array}$ \\
Ocupações: & NÃO INFORMADO \\
Formação: & $\begin{array}{l}\text { Farmácia, UFPE, Recife, 1940; Contabilidade, Fac. de Comércio, Recife, } \\
\text { 1940; Oficial da Reserva do Exército - Corpo de Saúde. }\end{array}$ \\
Outras & $\begin{array}{l}\text { ANC: Subcomissão da Família, do Menor e do Idoso, da Comissão da } \\
\text { Família, da Educação, Cultura e Esportes, da Ciência e Tecnologia e da } \\
\text { Informações: } \\
\text { Comunicação: Titular, 1987; Subcomissão dos Direitos Políticos, dos Direitos } \\
\text { Coletivos e Garantias, da Comissão da Soberania e dos Direitos e Garantias } \\
\text { do Homem e da Mulher: Suplente, 1987. }\end{array}$ \\
\hline
\end{tabular}

\section{5}

\begin{tabular}{l|l|l|l}
\hline Nome: & Vítor Buaiz \\
\hline Partido: & PT & UF: & ES \\
Legislaturas: & $\begin{array}{l}\text { Médico e Professor } \\
1987-1991\end{array}$ \\
Ocupações: & $\begin{array}{l}\text { Médico Plantonista do Pronto Socorro Particular de Vitória, 1970; Médico da } \\
\text { Secretaria da Saúde do Estado do Espírito Santo, 1969-1971; Médico da } \\
\text { Administração do Porto de Vitória, 1969-1971; Médico do Inamps, 1969-; } \\
\text { Auxiliar de Ensino Voluntário, 1969-1971 e Contratado, 1971-1979, do } \\
\text { Departamento de Clínica Médica do Centro Biomédico da UFES; } \\
\text { Coordenador do Ambulatório de Esquistossomose do Hospital das Clínicas } \\
\text { da UFES, 1970-; Secretário do Centro de estudos do Hospital das Clínicas } \\
\text { da UFES, 1974-1976; Professor Assistente do Departamento de Clínica } \\
\text { Médica do Centro Biomédico da UFES, 1979. } \\
\text { Medicina, UFES, Vitória, 1962-1967; Pós-Graduação em Clínica Médica, }\end{array}$ \\
Formação: & $\begin{array}{l}\text { UFRJ, Rio de Janeiro, 1968. } \\
\text { ANC: Subcomissão dos Municípios e Regiões, da Comissão da Organização } \\
\text { do Estado: Titular, 1987; Subcomissão de Saúde, Seguridade e do Meio } \\
\text { Ambiente, da Comissão da Ordem Social: Suplente, 1987. }\end{array}$ \\
Outras \\
Informações:
\end{tabular}

056

\begin{tabular}{l|l|l|l}
\hline Nome: & \multicolumn{2}{|l}{ Waldyr Ortêncio Pugliesi } \\
\hline Partido: & PTB, 1962-1966; MDB, 1966-1979; PMDB, 1980-. & UF: & PR \\
Profissões: & Cirurgião-Dentista & \multicolumn{2}{l}{} \\
\cline { 2 - 3 }
\end{tabular}




\begin{tabular}{|c|c|}
\hline Legislaturas: & $1987-1991$ \\
\hline Ocupações: & NÃO INFORMADO \\
\hline Formação: & Odontologia, Univ. Triângulo Mineiro, Uberaba, 1956-1958. \\
\hline $\begin{array}{l}\text { Outras } \\
\text { Informações: }\end{array}$ & $\begin{array}{l}\text { ANC: Subcomissão do Sistema Eleitoral e Partidos Políticos, da Comissão } \\
\text { da Organização Eleitoral, Partidária e Garantia das Instituições: Titular, 1987; } \\
\text { Subcomissão da Política Agrícola e Fundiária e da Reforma Agrária, da } \\
\text { Comissão da Ordem Econômica: Suplente, 1987. }\end{array}$ \\
\hline
\end{tabular}

057

\begin{tabular}{|c|c|c|c|}
\hline \multirow{2}{*}{$\begin{array}{l}\text { Nome: } \\
\text { Partido: }\end{array}$} & \multicolumn{3}{|l|}{ Walmor Paulo de Luca } \\
\hline & PTB, 1964-1965; MDB, 1966-1979; PMDB, 1980-. & UF: & SC \\
\hline Profissões: & \multicolumn{3}{|l|}{ Servidor Público e Farmacêutico Bioquímico } \\
\hline Legislaturas: & \multicolumn{3}{|l|}{$1975-1979,1979-1983,1983-1987$ e $1987-1991}$. \\
\hline Ocupações: & \multicolumn{3}{|l|}{ NÃO INFORMADO } \\
\hline Formação: & \multicolumn{3}{|c|}{ Farmacêutico Bioquímico, Fac. de Farmácia, UFPR, Curitiba, 1962.} \\
\hline $\begin{array}{l}\text { Outras } \\
\text { Informações: }\end{array}$ & \multicolumn{3}{|l|}{ ANC: Comissão da Ordem Econômica: Suplente. } \\
\hline
\end{tabular}

058

\begin{tabular}{|c|c|c|c|}
\hline \multirow{2}{*}{$\begin{array}{l}\text { Nome: } \\
\text { Partido: }\end{array}$} & \multicolumn{3}{|l|}{ Osvaldo Doreto Campanari } \\
\hline & $\begin{array}{l}\text { MDB, 1967-1979; PMDB, 1980-1990; PSDB, } \\
\text { 1990-. }\end{array}$ & UF: & SP \\
\hline Profissões: & \multicolumn{3}{|l|}{ Médico } \\
\hline Legislaturas: & \multicolumn{3}{|l|}{$1983-1987$ e $1987-1991}$. \\
\hline Ocupações: & \multicolumn{3}{|c|}{$\begin{array}{l}\text { Médico Oftalmologista, Centro de Saúde de Marília, SP. Inspetor na Área de } \\
\text { Oftalmologia, SP. }\end{array}$} \\
\hline Formação: & \multicolumn{3}{|l|}{ Medicina, UFPR, Curitiba, 1952-1958. } \\
\hline $\begin{array}{l}\text { Outras } \\
\text { Informações: }\end{array}$ & \multicolumn{3}{|c|}{$\begin{array}{l}\text { ANC: Subcomissão da Questão Urbana e Transporte, da Comissão da } \\
\text { Ordem Econômica: Suplente, 1987; Subcomissão dos Negros, Populações } \\
\text { Indígenas, Pessoas Deficientes e Minorias, da Comissão da Ordem Social: } \\
\text { Primeiro-Vice-Presidente, } 1987 .\end{array}$} \\
\hline
\end{tabular}

